RAQUEL BOTELHO SANTORO

\title{
A ATUAÇÃO DO SUPREMO TRIBUNAL FEDERAL NA EFETIVIDADE PLENA DOS DIREITOS FUNDAMENTAIS: ANÁLISE CRÍTICA DA JURISPRUDÊNCIA RECENTE
}

\author{
DISSERTAÇÃO DE MESTRADO \\ ORIENTADOR: PROFESSOR ASSOCIADO ALEXANDRE DE MORAES
}

Faculdade de Direito da Universidade de São Paulo

São Paulo, SP 
RAQUEL BOTELHO SANTORO

\section{A ATUAÇÃO DO SUPREMO TRIBUNAL FEDERAL NA EFETIVIDADE PLENA DOS DIREITOS FUNDAMENTAIS: ANÁLISE CRÍTICA DA JURISPRUDÊNCIA RECENTE}

Dissertação apresentada ao Departamento de Direito de Estado da Faculdade de Direito da Universidade de São Paulo, para a obtenção do título de mestre em direito

Área de Concentração: Direito do Estado Direito Constitucional

Orientador: Prof. Associado Alexandre de Moraes 


\section{QUADRO DE REFERÊNCIA BIBLIOGRÁFICA}

A atuação do Supremo Tribunal Federal na efetividade plena dos direitos fundamentais: análise crítica da jurisprudência recente

Constitucional / Raquel Botelho Santoro. - São Paulo: R. B. Santoro, 2013. 201 p.; $30 \mathrm{~cm}$.

Dissertação (Metrado) - Faculdade de Direito da USP, 2013.

Orientador: Prof. Alexandre de Moraes

Notas de rodapé

Inclui bibliografia.

1. Direitos fundamentais. 2. Direito constitucional. 3. Ativismo judicial 4. Interpretação 5. Mutação constitucional I. Título. 
SANTORO, R. B. A atuação do Supremo Tribunal Federal na efetividade plena dos direitos fundamentais: análise crítica da jurisprudência recente. 2013. 201p. Dissertação (mestrado em direito) - Faculdade de Direito, Universidade de São Paulo.

O presente trabalho analisa a postura do Supremo Tribunal Federal na efetividade dos direitos fundamentais pelo exame de casos concretos recentes. Para tanto, faz uma digressão acerca dos direitos fundamentais, sua evolução, positivação, técnicas de interpretação e suas críticas. Posteriormente, busca examinar duas possíveis consequências práticas dessas interpretações, dentre elas o ativismo judicial e a mutação constitucional. Frente a essas premissas, identifica sua conformação aos casos concretos e conclui pela existência de uma postura ativa do Supremo Tribunal Federal, a qual defende apontando e refutando as críticas a esse modelo.

Palavras-chave: Direitos Fundamentais. Ativismo Judicial. Mutação Constitucional. Interpretação. Judiciário Ativo.

\section{Abstract}

SANTORO, R. B. The role of the Supremo Tribunal Federal on the effectiveness of the constitutional rights: a critical analysis of recent precedents. 2013. 201p. Dissertação (mestrado em direito) - Faculdade de Direito, Universidade de São Paulo.

This work analyses the role of the Supremo Tribunal Federal on the effectiveness of the constitutional rights through the exam of recent precedents. For this purpose, it considers the evolution, interpretation techniques and critiques concerning the constitutional rights. In sequence, it seeks to examine two possible practical consequences of those interpretations - judicial activism and constitutional transformation. Considering those premises, it seeks to identify them in the precedents analyzed and concludes that the Supreme Court has an active role, which is defended by pointing e rejecting the critiques applied.

Key-words: Constitutional rights. Judicial activism. Constitutional transformation. Interpretation. Active Judiciary. 


\section{LISTA DE ABREVIATURAS}

ADC - Ação Declaratório de Constitucionalidade

ADI - Ação de Direta de Inconstitucionalidade

ADPF - Arguição de descumprimento de preceito fundamental

AgRgRE - Agravo regimental em recurso extraordinário

Art. - artigo

CF - Constituição Federal

HC - habeas corpus

Inc. - inciso

LC - lei complementar

Min. - Ministro

NR - Nota de rodapé

ONU - Organização das Nações Unidas

RE - Recurso Extraordinário

STF - Supremo Tribunal Federal

STJ - Superior Tribunal de Justiça 
Para minha mãe e meu pai pela inspiração, apoio e amor. Ainda uma vez mais para minha mãe, pela revisão valorosa. Para a Bruna, pelo apoio eterno. E para o Dudu, que é minha alegria, força e incentivo. 


\section{SUMÁRIO}

Introdução

1. A evolução da concepção de direitos fundamentais

e suas características atuais

$1.1 \mathrm{O}$ paradigma liberal e a dimensão subjetiva dos direitos fundamentais ................12

$1.2 \mathrm{O}$ paradigma social e a dimensão objetiva dos direitos fundamentais.....................16

1.2.1 O paradigma social no segundo pós-guerra e os direitos fundamentais

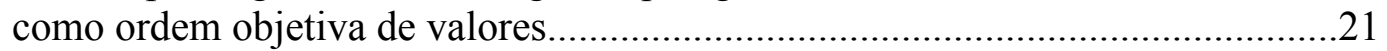

1.3 A crise do paradigma social e o momento histórico atual ...................................25

2. Da interpretação e aplicação dos direitos fundamentais..

2.1 Dos direitos fundamentais como princípios e da distinção entre princípios e regras.

2.2 A interpretação e aplicação dos direitos fundamentais aos casos concretos - a racionalidade da argumentação jurídica com base na teoria do discurso de Alexy.....

2.2.1 Da pretensão de correção no discurso jurídico.............................................36

2.2.2 A fundamentação jurídica -- justificação interna e externa...........................37

2.2.3 A justificação externa por meio da argumentação jurídica

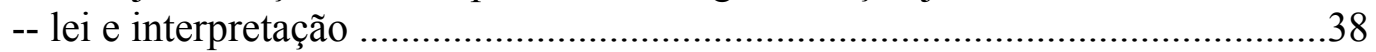

2.2.4 A justificação externa por meio da argumentação dogmática ......................41

2.2.5 A justificação externa pelo uso dos precedentes ..........................................43

2.2.6 A justificação externa por meio de argumentos jurídicos

especiais e de argumentos práticos....................................................................4

2.2.7 O discurso prático geral e sua relação com o discurso jurídico......................45

2.3 A técnica de ponderação e sua racionalidade ....................................................47

2.4 A improcedência das críticas à técnica da ponderação ..........................................53

3. O posicionamento do Supremo Tribunal Federal na

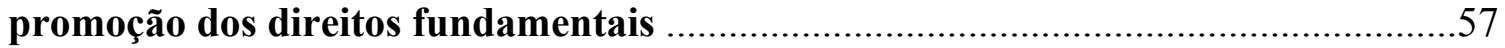

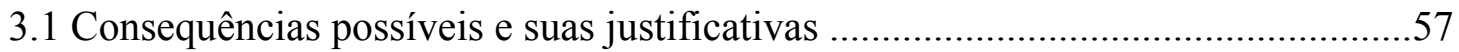

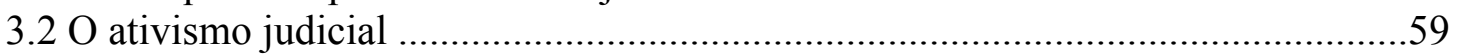

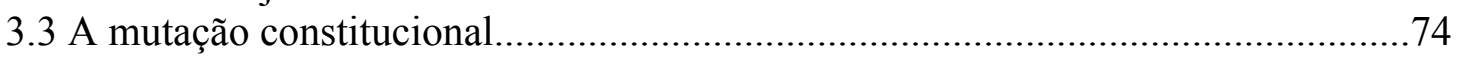

3.4 O processo de escolha dos casos concretos a serem analisados ............................80

4. Do direito fundamental à dignidade da pessoa humana, à isonomia e à igualdade -- interpretação do Supremo

Tribunal Federal acerca dos incisos I, XLI e XLII, do artigo $5^{\circ}$ e do inciso III, do artigo $1^{\circ}$,

todos da Constituição Federal.

4.1 Do julgamento do $\mathrm{HC} \mathrm{n}^{\circ} 82.424 / \mathrm{RS}$-- a questão do racismo ...............................84

4.2 Do julgamento sobre a união estável homoafetiva ................................................96

4.3 Conclusão parcial sobre a postura do Supremo

Tribunal Federal nas hipóteses.

5. Do direito fundamental à presunção de inocência -- interpretação

do Supremo Tribunal Federal acerca do inciso LVII, do artigo $5^{\circ}$,

da Constituição Federal.

5.1 Do julgamento do $\mathrm{HC} \mathrm{n}^{\circ}$ 84.078/MG

5.2 Do julgamento da constitucionalidade da Lei da Ficha Limpa

5.3 Conclusão parcial sobre a postura do Supremo

Tribunal Federal nas hipóteses. 
6. A postura do Supremo Tribunal Federal quanto à efetividade dos direitos sociais

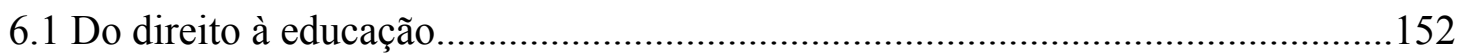

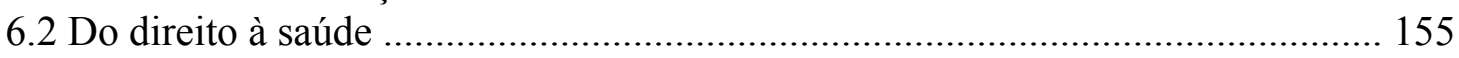

6.3 Conclusão parcial sobre a postura do Supremo

Tribunal Federal nas hipóteses

7. A postura do Supremo Tribunal Federal quanto à efetividade

do direito à vida

$7.1 \mathrm{O}$ julgamento sobre pesquisas com células-tronco .............................................162

7.2 Conclusão parcial sobre a postura do Supremo

Tribunal Federal nas hipóteses.

8. A postura do Supremo Tribunal Federal na efetividade dos direitos fundamentais

8.1 A postura predominante na promoção da eficácia dos direitos fundamentais. ....182

8.2 Uma defesa dessa postura

9. Reflexões conclusivas

Bibliografia. 


\section{INTRODUÇÃO}

O presente trabalho pretende, por meio da análise de alguns casos representativos da jurisprudência recente do Supremo Tribunal Federal ("STF"), avaliar a postura da Corte no que diz respeito à promoção dos direitos fundamentais ${ }^{1}$.

Para tanto, selecionamos alguns precedentes emblemáticos em que o STF definiu a maneira de interpretação e aplicação de alguns direitos fundamentais, tanto por meio da análise de constitucionalidade de algumas leis, quanto por meio da própria definição da forma interpretativa que melhor serviria à aplicação dos referidos direitos.

Igualmente, serão analisados casos em que o Supremo Tribunal teve de restringir a eficácia de um direito fundamental quando visto em confronto com um outro direito de igual relevância, o que demonstrará as técnicas de interpretação adotadas, permitindo uma avaliação concreta da espécie de postura adotada por aquela Corte quanto à aplicabilidade e consequente efetividade dos direitos fundamentais.

Será possível perceber, durante a análise, que a postura do Supremo Tribunal não será sempre coerente e que muitas vezes, não apenas por questões de composição da Corte, mas também por questões eminentemente políticas, o STF adotará posturas diversas quanto aos mesmos direitos fundamentais, o que também será objeto de análise, por também refletir, em um exame conjuntural, em que medida a interpretação e aplicação dos direitos fundamentais é restringida pela própria Corte Suprema e quais são os fatores que originam essa restrição, que pode ou não parecer legítima ao final do trabalho.

\footnotetext{
1 Aqui, vale fazer a seguinte distinção entre direitos fundamentais e direitos humanos: "En suma, la diferencia entre los derechos humanos y los derechos fundamentales depende del lugar en el que se ponga el acento de su validez y de qué tipo de validez es al que se dé primacía. En los derechos humanos, partimos de una validez axiológica en la que nos situamos en un nivel del discurso prejuridico, descansando su fundamento e malas razones que se entienden como suficientes o buenas para que el legislador las recoja, valorándolas y regulándolas. (...) En cambio, cuando hablamos de derechos fundamentales, nos referimos al plano normativo jurídico, sobre todo al constitucional, sin olvidar las demás normas de desarrollo, estimando que su validez es formal y por lo tanto, que tales derechos valen en función de su acogimiento por el Derecho positivo según la consideración que, siguiendo el procedimiento democrático, han llevado a cabo los representantes de la ciudadanía, sin desconocer que haya pautas Morales externas al bloque constitucional que sirven de crítica a los ya regulados, pudiendo ser acogidas tales posiciones en textos ulteriores con la creación de nuevas normativas, modificando las vigentes, completándolas o derogándolas.” GOMÉZ, Maria Isabel Garrido. Derechos Fundamentales y Estado Social y Democrático de Derecho. Madrid: Editorial Dilex, sem ano. p.24.
} 
Mas antes de adentrarmos à análise propriamente dita dos julgados, o que permitirá a nossa conclusão sobre a postura adotada pelo Supremo Tribunal Federal quando confrontado com a aplicabilidade e eficácia dos direitos fundamentais, faremos um retrospecto sobre os direitos fundamentais em si, sua evolução e importância e os processos que culminaram com a sua positivação nos textos constitucionais.

Em seguida, fixadas as premissas históricas relacionadas aos direitos fundamentais, demonstraremos a caracterização desses direitos como princípios, bem como as consequências advindas dessa configuração, notadamente no que diz respeito às técnicas interpretativas que devem ser adotadas pelos Tribunais quando com eles confrontados.

Então, adotaremos como técnica interpretativa dos princípios o método da ponderação nos termos da teoria do discurso desenvolvida por Robert Alexy, teoria essa que demonstraremos conferir à ponderação a racionalidade que muitos críticos entendem faltar à técnica em questão.

Definidas assim essas três premissas, demonstraremos duas consequências que delas podem advir no que tange ao posicionamento do Supremo Tribunal Federal, sendo uma delas a caracterização de ativismo judicial e a outra a configuração de mutação constitucional.

Analisaremos, então, as características tanto do ativismo judicial quanto da mutação constitucional, abordando inclusive suas críticas para que, no momento seguinte de análise dos casos concretos, possamos nos posicionar sobre a configuração ou não de uma dessas duas posições na atuação concreta do Supremo Tribunal Federal, a fim de concluirmos, em geral, qual é a postura da Corte quanto a efetividade dos direitos fundamentais.

Por fim, analisados os casos concretos representativos que selecionamos, demonstraremos que, apesar de verificada, em alguns casos específicos, a manifestação ativista do Supremo Tribunal Federal, essa não pode ser entendida como regra e nem como posição frequente da Corte. 
Conforme tentaremos defender, o STF se caracteriza, na maior parte dos casos analisados, como um Tribunal ativo e realizador de mutações constitucionais frequentes, mas não se configura como um Tribunal ativista.

Feitas essas últimas considerações, concluímos o trabalho com a retomada dos pontos tratados e a defesa final da posição que adotamos ao longo do nosso estudo. 


\section{A EVOLUÇÃO DA CONCEPÇÃO DE DIREITOS FUNDAMENTAIS E SUAS CARACTERÍSTICAS ATUAIS}

\subsection{O paradigma liberal e a dimensão subjetiva dos direitos fundamentais}

A introdução do presente trabalho passa necessariamente por uma análise da evolução na concepção dos direitos fundamentais em suas diversas gerações e dimensões, bem como de sua importância e positivação nos ordenamentos jurídicos e das consequentes técnicas interpretativas que foram desenvolvidas a fim de lhes conferir a maior eficácia possível diante dos casos concretos.

Para tanto, não podemos nos furtar a iniciar a análise pelo paradigma liberal de desenvolvimento estatal e a dimensão subjetiva que os direitos fundamentais tinham à época.

Ora, a problemática que se pretende analisar tem uma de suas origens na dimensão subjetiva dos direitos fundamentais, segundo a qual esses direitos ensejam uma pretensão a que se adote certo comportamento, ou a que se produzam certos efeitos em dadas relações jurídicas entre particulares ${ }^{2}$.

A compreensão do papel dos direitos fundamentais, tomada nesse sentido, sofreu alterações consideráveis nos diversos paradigmas que marcaram seu desenvolvimento, apresentando, nos dias atuais, características adquiridas ao longo dessa evolução ${ }^{3}$.

Vale ressaltar, inicialmente, que a apreciação da dimensão subjetiva dos direitos fundamentais não pode estar dissociada de seu elemento intrínseco de historicidade, pois, de acordo com o pensamento de Norberto Bobbio, "os direitos do

\footnotetext{
${ }^{2}$ Cf. MENDES, Gilmar Ferreira, COELHO, Inocêncio Mártires e BRANCO, Paulo Gustavo Gonet, Curso de Direito Constitucional, São Paulo: Saraiva, 2007. p. 255

${ }^{3} \mathrm{O}$ estudo dos paradigmas se mostra necessário dada a imprescindibilidade de análise das premissas elementares dos direitos fundamentais em sua evolução, mas não implica, na posição adotada nesse trabalho, a concordância com a ideia de Khun de que não haja possibilidade de comunicação interparadigmática. Adota-se, portanto, um modelo mais vinculado à teoria de Popper, que admite que os novos paradigmas absorvem certos elementos dos antigos. Nesse sentido também é SARMENTO, Daniel, Direitos Fundamentais e Relações Privadas, Rio de Janeiro: Lumen Juris, 2006, pp. 3-4
} 
homem, por mais fundamentais que sejam, são direitos históricos, ou seja, nascidos em certas circunstâncias, caracterizadas por lutas em defesa de novas liberdades contra velhos poderes, e nascidos de modo gradual, não todos de uma vez e nem de uma vez por todas $" 4$.

Levando em conta esse aspecto histórico, portanto, é que o estudo da dimensão subjetiva dos direitos fundamentais, neste trabalho, será coincidente com uma análise do paradigma liberal com o qual se identifica no tempo, enquanto o estudo da dimensão objetiva será coincidente com a análise do paradigma social, realizando-se ainda a apreciação de um possível - mas ainda controvertido - paradigma pós-social.

O paradigma liberal dos direitos fundamentais, cuja origem é contemporânea às Declarações de Direitos da Virgínia (1776) e à Declaração dos Direitos do Homem e do Cidadão (1789) ${ }^{5}$, partia do pressuposto de que os homens seriam dotados de direitos inatos e de que esses direitos sobrepunham-se ao Estado. Nesse sentido, a função estatal primordial seria a de garantir referidos direitos contra suas próprias ações que pudessem ser consideradas prejudiciais aos indivíduos, ideia que está no cerne do constitucionalismo.

Essa ideia de direitos inatos e superiores ao Estado foi fruto do esforço empreendido pela burguesia contra o absolutismo e despotismo monárquicos e também contra os privilégios de classe usufruídos pela nobreza e pelo clero, que não mais possuíam o poderio econômico. Criou-se, portanto, a ideia de que haveria um espaço de liberdades individuais imune a intervenções estatais e objeto de sua proteção irrestrita.

No entanto, esse dever do Estado em relação aos direitos individuais inatos dos indivíduos poderia se configurar meramente como um dever de abstenção. Segundo

\footnotetext{
${ }^{4}$ BOBBIO, Norberto, A Era dos Direitos. Rio de Janeiro: Campus, 1992, p. 5.

${ }^{5}$ Vale dizer que, para Manoel Gonçalves Ferreira Filho, a primeira expressão dos direitos de primeira geração foi, na realidade, a Declaração dos Direitos do Homem e do Cidadão, de 26/08/1789, que até hoje é considerada, segundo ele, como legislação vigente e integrante do bloc de constitutionnalité francês, a despeito de ser temporalmente posterior à Declaração de Direitos da Virgínia (1776). FERREIRA FILHO, Manoel Gonçalves. Princípios Fundamentais do Direito Constitucional. São Paulo: Saraiva, 2010, p. 85. Nesse sentido, também, é a lição de SARLET, A Eficácia... Op. cit. pp. 44-45
} 
essa visão lockeana ${ }^{6}$, seria dever do Estado permanecer inerte em relação a certas prerrogativas individuais, sendo-lhe proibida e reprovável a intervenção nesses aspectos.

Assim, manifestavam-se por meio das constituições as ideias liberais de que existiriam direitos inatos dos indivíduos, superiores ao ente estatal e à comunidade política, e de que o Estado, frente a esses direitos, tinha o dever tanto de protegê-los quanto de se abster de intervir nos campos de liberdade individual.

Percebe-se, portanto, uma nítida correspondência entre a evolução da concepção filosófica dos direitos fundamentais e a sua consequente e seguinte positivação, que se deu exatamente por meio das constituições.

Paralelamente a esse movimento de positivação dos direitos fundamentais por meio das constituições, as regras que visavam a regular as relações entre os particulares também passaram por um momento próprio e distinto de positivação, cujo instrumento foi o Código Civil.

Essa dicotomia rígida então existente previa que a Constituição era o instrumento que regularia as relações entre os Estados e os indivíduos, baseada nos direitos fundamentais, enquanto o Código Civil seria o instrumento responsável por disciplinar as relações entre os indivíduos, baseado estritamente no princípio da autonomia privada.

De acordo com essa concepção, criava-se uma contraposição entre Estado e sociedade, que se apresentavam como duas estruturas rígidas e incomunicáveis, reguladas cada qual por um desses instrumentos previamente determinados. Estabeleciase, portanto, uma diferenciação rígida entre a esfera privada e a pública.

\footnotetext{
6 “(...) John Locke (1632-1704), primeiro a reconhecer aos direitos naturais e inalienáveis do homem (vida, liberdade, propriedade e resistência) uma eficácia oponível, inclusive, aos detentores do poder, este, por sua vez, baseado no contrato social, ressaltando-se, todavia, a circunstância de que, para Locke, apenas os cidadãos (e proprietários, já que identifica ambas as situações) poderiam valer-se do direito de resistência, sendo verdadeiros sujeitos, e não meros objetos do governo." SARLET, Ingo Wolfgang. A Eficácia dos Direitos Fundamentais. Porto Alegre: Livraria do Advogado, 2007. pp. 47-48. No mesmo sentido são as considerações de BINENBOJM, Gustavo. A Nova Jurisdição Constitucional Brasileira - Legitimidade democrática e instrumentos de realização. Rio de Janeiro: Renovar, 2010. pp. 17-18.
} 
Essas características, em consequência, determinaram a visão dos direitos fundamentais como direitos públicos subjetivos de dimensão coletiva ${ }^{7}$ e eficácia apenas vertical, ou seja, apenas contra a ação do Estado.

Como exemplo dessa visão, pode-se citar a doutrina dos direitos públicos subjetivos desenvolvida por Georg Jellinek, no final do século XIX ${ }^{8}$. Segundo o autor pioneiro em identificar os elementos da relação jurídica de direito público -, os indivíduos conservariam quatro status diferentes perante o Estado.

O primeiro dos status advogados por Jellinek seria o status subjectionis, segundo o qual o indivíduo estaria subordinado ao Estado, possuindo deveres perante ele. Em contraposição, haveria o status negativo, regulando o âmbito de liberdades individuais que estaria a salvo da intervenção estatal. Jellinek também previa a existência de um status civitatis, pelo qual os indivíduos teriam o direito de exigir determinadas prestações do Estado e por fim, de um status ativo, pelo qual o indivíduo exerceria seus direitos políticos ${ }^{9}$.

Essas quatro posições acima explicitadas definiriam duas possíveis funções para os direitos fundamentais, que corresponderiam a direitos de defesa contra a atuação estatal e a direitos de prestação ao indivíduo por parte do Estado, características

\footnotetext{
7 “A proteção desse status para um determinado indivíduo significa a proteção da existência desse status para todos os súditos do Estado, uma vez que não se está a resguardar o direito específico de uma pessoa, mas o direito de todos perante o ente estatal." KAUFMANN, Rodrigo de Oliveira, Dimensões e Perspectivas da Eficácia Horizontal dos Direitos Fundamentais - Possibilidades e Limites da Aplicação no Direito Constitucional Brasileiro. Dissertação apresentada como requisito para adquirir o título de mestre, na UnB, em 2003. Orientador: José Carlos Moreira Alves.., p. 59

${ }^{8}$ Para Alexy, que dedica um capítulo de sua Teoria dos Direitos Fundamentais aos status de Jellinek, essa teoria mereceria destaque na análise sobre direitos fundamentais "no sólo por su importancia historica como ejemplo de una gran conceptualización y teorización jurídicas. En la actualidad, sigue teniendo vigência como base para la classificación de los derechos fundamentales. Como habrá de mostrarse, partes esenciales de ella se cuentan entre los conocimientos seguros em el ámbito de los derechos fundamentales, algo que ya significa mucho en un campo controvertido". ALEXY, Robert. Teoría de los Derechos Fundamentales. Madri: Centro de Estudios Políticos y Constitucionales, 2007, p. 219. Daniel Sarmento assim sintetiza a posição de Jellinek: "Para Jellinek, os direitos públicos subjetivos não eram direitos naturais e inatos, que antecediam ao poder estatal, mas autolimitações a este poder, que geravam pretensões do individuo frente ao Estado, as quais deveriam ser exercidas exclusivamente dentro do marco estabelecido pelas leis." SARMENTO, Daniel, Direitos Fundamentais... Op. cit., pp. 109/110. A esse respeito, ver também MENDES, Gilmar Ferreira, COELHO, Inocêncio Mártires e BRANCO, Paulo Gustavo Gonet, Op. cit., p. 245.

${ }^{9}$ Para uma melhor explicação a respeito dos quatro status e a sua importância em uma teoria dos direitos fundamentais, ver ALEXY, Robert. Teoría de los Derechos... Op. cit., pp. 220-232.
} 
essas que configuraram o caráter desses direitos desde a sua positivação e ao longo do desenvolvimento do paradigma liberal.

Assim, podemos concluir que os direitos fundamentais no paradigma liberal se identificam com aqueles direitos fundamentais denominados de primeira geração (ou primeira dimensão) ${ }^{10}$. São eles, em suma, os direitos civis e políticos, notadamente os relativos à vida, à liberdade, à propriedade, à igualdade formal (perante a lei) ${ }^{11}$ e à participação política. Todos esses são denominados também como direitos de defesa de cunho negativo, ou seja, que implicam um dever de abstenção por parte do Estado de intervir nas relações privadas.

\subsection{O paradigma social e a dimensão objetiva dos direitos fundamentais}

No entanto, o processo de evolução dos direitos fundamentais teve continuidade e as concepções então vigentes foram complementadas e substituídas por novas teorias e doutrinas, bem como pelos novos contextos históricos pelos quais passou a humanidade.

Como vimos, o liberalismo foi responsável pelo desenvolvimento do capitalismo $^{12}$. Esse modelo econômico, somado à industrialização - e a consequência de seu desenvolvimento para os indivíduos, em especial para a classe trabalhadora -, foram ambos responsáveis por evidenciar a insuficiência dos direitos então previstos e assegurados pelo individualismo característico do constitucionalismo liberal para a proteção da dignidade humana.

\footnotetext{
${ }^{10}$ Há controvérsia doutrinária a respeito da definição terminológica, em que se discute o uso da expressão "geração" e se pretende substituí-la por "dimensão". Vale ressaltar que o uso da expressão geração não implica dizer que os direitos de $2^{\mathrm{a}}$ geração tenham substituído os de $1^{\mathrm{a}}$ geração. A expressão não pretende retirar dos direitos fundamentais o seu notável caráter de complementaridade e de evolução por meio do acréscimo de direitos, e não por sua substituição. Nesse sentido, considera-se equivalente e igualmente possível o uso de ambas as expressões. Nesse sentido é SARLET, Ingo Wolfgang. A Eficácia... Op. cit., pp. 54 e 55.

11 " $O$ desenho da máscara foi de início a igualdade formal resultante da não-intervenção do Estado na sociedade civil. Para tanto, abstraindo as condições sociais concretas, firmou-se um conceito abstratoliberal que redundou numa sequência história contraditória. Para por o Estado-lei no lugar do Estado-rei, em condições de proteger a liberdade individual contra o arbitrio real, mas buscando no fundo proteger a auto-regulação do Mercado, os liberais usaram o Estado-protetor contra o Estado-interventor. Praticaram uma intervenção 'negativa'. Assim, abriram com o não-intervencionismo as portas para o intervencionismo." BARROS, Sérgio Resende. Contribuição Dialética para o Constitucionalismo. Campinas: Millennium, 2008. p. 77.

${ }^{12}$ SARMENTO, Daniel. Direitos Fundamentais... Op. cit., p. 17.
} 
Tornou-se evidente, nesse momento, a necessidade de participação de outras classes sociais, além da burguesia, no processo político. Para tanto, era necessária a criação de mecanismos que assegurassem aos trabalhadores direitos mínimos que lhes permitissem o gozo das prerrogativas de igualdade e liberdade conquistadas desde o paradigma liberal.

Surge, nesse contexto, o Estado do Bem-Estar Social (Welfare State), cujas primeiras manifestações constitucionais se deram na Constituição mexicana de 1917 e na constituição da República de Weimar, de $1919^{13}$. Referidos instrumentos passaram a prever direitos que visavam a garantir condições mínimas de vida à população, estando incluídos no seu rol os direitos sociais em geral.

Nesse sentido, a Constituição de Weimar representou um marco na superação da teoria de direitos públicos subjetivos de Jellinek ${ }^{14}$, passando a comportar uma noção axiológica dos direitos fundamentais ${ }^{15}$. Essa constituição trouxe uma heterogeneidade de direitos, reivindicados por diversos setores sociais.

Assim como a teoria de Jellinek foi importante no paradigma liberal, o paradigma social contou com a teoria das garantias institucionais, de Martin Wolff e Carl Schmitt e com a teoria da integração de Rudolf Smend, que advogava uma visão axiológica dos direitos fundamentais.

Para Martin Wolff e Carl Schmitt, as Constituições não protegeriam somente os direitos fundamentais, conferindo também proteção a certas instituições e

\footnotetext{
${ }^{13}$ Aqui, novamente, Manoel Gonçalves Ferreira Filho aponta a Constituição de Weimar como o documento símbolo do paradigma social, não obstante tenha ela sido posterior, temporalmente, à Constituição Mexicana. FERREIRA FILHO, Manoel Gonçalves. Princípios... Op. cit., p. 87.

14 Vale relembrar que "[a] teoria de Jellinek concebia os direitos a partir de uma perspectiva exclusivamente subjetiva, o que era natural considerando a ambiência cultural da época, em que o paradigma jurídico reinante era ainda o do Estado Liberal." SARMENTO, Daniel. Direitos Fundamentais... Op. cit., p. 110.

${ }^{15}$ ALEXY, Robert. Teoría de los Derechos... Op. cit., pp. 125-128. Também a esse respeito, segundo Kaufmann, a teoria de direitos públicos subjetivos de Jellinek merece diversas críticas, dentre elas a de que, nessa concepção, o direito público era confundido com o direito do Estado. Além disso, os status apenas seriam embriões de direitos fundamentais, estando na dependência de uma atitude do legislador para que tivessem validade. Assim, referida teoria negava aos direitos fundamentais aplicação imediata. Por fim, referida teoria ainda não concedia aos direitos fundamentais eficácia própria de princípios gerais de direito, inexistindo, então, o seu efeito irradiador, que seria alcançado apenas pelas formulações teóricas que se seguiram. KAUFMANN, Rodrigo de Oliveira, Op. cit., pp. 65-66.
} 
institutos que, como bens jurídicos coletivos, representaram desde já uma passagem do individualismo característico do Estado Liberal para um paradigma social ${ }^{16}$.

Já segundo a teoria de Smend, o Estado estaria em constante renovação, por meio da integração de uma comunidade de valores e de culturas. Esse processo de integração, que se daria por meio de três situações diferentes, evidenciaria que a formação do Estado, de seus valores e de sua natureza substantiva, não se dá por mero somatório de interesses diversos, mas pela interrelação entre pessoas, soberano, órgãos e culturas, por meio de um processo complexo de integração ${ }^{17}$.

A teoria da integração de Smend altera a concepção de direitos fundamentais no passo em que insere o elemento de "valor" na teoria constitucional, demonstrando que a Constituição não deve se restringir aos direitos liberais clássicos, devendo incorporar também os valores gerais da sociedade, de forma a ter uma eficácia que envolva todas as questões do Estado ${ }^{18}$.

Nesse diapasão, os direitos fundamentais passam a traduzir exatamente um sistema cultural de valores, representando o ponto de convergência entre as aspirações de todos os integrantes de uma sociedade ${ }^{19}$.

Importante também observar como o contexto econômico participou de uma nova concepção do papel do Estado na vida social. A crise econômica de 1929 demonstrou a falência de um modelo econômico liberal, o que criou os alicerces para a construção de novas doutrinas segundo as quais o Estado deveria passar a intervir na economia para regular e até mesmo para controlar o andamento do mercado.

\footnotetext{
${ }^{16}$ Nesse sentido é SARMENTO, Daniel. Direitos Fundamentais... Op. cit., pp. 110/111.

17 "Para SMEND, o sentido integrativo do Estado se revela por meio de três tipos de inter-relações: a integração pessoal representada pelas relações entre pessoas dentro de uma comunidade a partir da figura do soberano, responsável maior pela continuidade desse processo integrativo; a integração funcional que significa uma integração processual entre as formas de vida capazes de criar um sentido do 'coletivo', capaz de dar função política e orgânica ao povo em vista a se renovarem as características e funções peculiares do Estado; e a integração material responsável por produzir os 'objetivos comuns' que justificam o funcionamento e a própria existência do Estado" KAUFMANN, Rodrigo de Oliveira, Op. cit., p. 68 .

18 "Smend defendia que a função essencial da Constituição é promover a integração na comunidade, o que só é possível a partir da tutela de valores, que sejam vividos e socialmente compartilhados." SARMENTO, Daniel. Direitos Fundamentais... Op. cit., p. 111. No mesmo sentido é ALEXY, Robert. Teoría de los Derechos... Op. cit., p. 126.

${ }^{19}$ Cf. KAUFMANN, Rodrigo de Oliveira, Op. cit., pp. 67-70.
} 
Ocorre, portanto, uma inversão do papel estatal, que deixa de se preocupar tão somente com a liberdade de seus cidadãos para focar também em seu bem estar. Referida mudança traz como consequência a alteração da postura do Estado, que passa a ser de intervencionismo nas relações sociais, ao procurar agir em favor dos segmentos menos protegidos da sociedade, tornando-se agente promotor de direitos fundamentais.

Segue-se que o Direito Privado começa a sofrer limitações, uma vez que a autonomia da vontade das partes passa a ser condicionada por normas de ordem pública previstas inclusive nos instrumentos de direito civil. Paralelamente, há a positivação de direitos sociais e econômicos, que passam a ser compreendidos como condições materiais necessárias para o gozo da liberdade formal já prevista desde o paradigma liberal ${ }^{20}$.

Os direitos sociais e econômicos incorporados às constituições no paradigma social são os chamados direitos fundamentais de segunda geração (ou dimensão), que têm como característica diferenciadora o seu caráter positivo ${ }^{21}$. No entanto, há que se observar que fazem parte também dessa geração as "liberdades sociais", que apesar de não terem esse caráter positivo, são direitos que se consagraram nesse paradigma social ${ }^{22}$.

Com as referidas alterações nos contextos histórico, econômico e político, as constituições deixam de ter as características que as marcaram no período liberal. Elas passam a ser consideradas como constituições dirigentes, prevendo e regulando grande variedade de situações e até mesmo contendo normas programáticas, cuja eficácia incerta posteriormente deu azo a grandes críticas às constituições sociais ${ }^{23}$.

\footnotetext{
${ }^{20}$ Nesse ponto é importante a definição de mínimo existencial, criação da Corte Constitucional alemã que permitiu que certos direitos econômicos e sociais tivessem seu cumprimento pleiteado individualmente pelos cidadãos perante o Poder Judiciário. Segundo essa construção, alguns direitos sociais básicos seriam pressupostos para o exercício da própria liberdade individual. A esse respeito, SARMENTO, Daniel, Direitos Fundamentais... Op. cit., p. 21.

${ }^{21}$ Caráter positivo em oposição ao posicionamento estatal negativo que caracterizava o paradigma liberal e que se consubstanciava na ausência de interferência do Estado nos direitos fundamentais.

${ }_{22}^{2}$ Nesse sentido é SARLET, Ingo Wolfgang, A Eficácia... Op. cit., p. 57

${ }^{23}$ As normas programáticas limitam-se a definir diretrizes de atuação do Estado e fins e objetivos que devem ser perseguidos pelo ente estatal, mas não dispõem a respeito da forma pela qual esses objetivos devem ser alcançados. Essa característica é muitas vezes responsável pelo descrédito da constituição, pois não são todas as promessas nela previstas que podem ser cumpridas na prática. Nesse sentido é SARMENTO, Daniel. Direitos... Op. cit., pp. 21-22.
} 
Consequentemente, a dicotomia rígida entre direito público e direito privado observada no paradigma liberal - em que predominava o privado sobre o público - é invertida no paradigma social. Isso porque deixa de haver uma separação tão rígida entre as duas esferas, o que é observado pelo efeito irradiador das normas constitucionais, que passam a intervir diretamente em domínios antes reservados ao direito privado.

O dogma da autonomia privada - princípio máximo que norteava as relações horizontais no paradigma liberal - é relativizado pelas normas de ordem pública e pelos direitos de liberdade, sociais e econômicos, previstos nas novas constituições dirigentes. Dessa forma, os particulares não mais estão livres do respeito e observância aos direitos fundamentais.

Essa constatação é ainda mais nítida ao se observar as relações privadas em que há notável desigualdade entre as partes e em que tanto o ordenamento quanto o Estado passam a agir de forma a proteger os interesses dos hipossuficientes, por meio da previsão dos direitos sociais e econômicos. Assim, pretende-se transformar em igualdade material a igualdade até então meramente formal conquistada no paradigma anterior ${ }^{24}$.

E todo esse contexto de desenvolvimento histórico e jurídico demonstra como, no paradigma social, se desenvolveu uma nova dimensão para os direitos fundamentais, que deixou de ser meramente subjetiva para passar a ser objetiva considerando-se os direitos fundamentais como princípios básicos da ordem constitucional $^{25}$, fundamentos do ordenamento jurídico estatal, responsáveis por positivar e representar os valores formadores da sociedade ${ }^{26}$.

Também decorre da dimensão objetiva dos direitos fundamentais o reconhecimento de que esses direitos são garantias de valores morais coletivos, tornando-

\footnotetext{
24 "Assim, abriram com o não intervencionismo as portas para o intervencionismo. A história logo desmascarou essa contradição. O Estado burguês liberal cedeu terreno ao Estado burguês social. Ainda ocultando a dominação de classe, agora pela pretensão de igualdade social composta com a intervenção do Estado na ordem econômica da sociedade civil, a doutrina mascarou por outra teoria formal - a da igualdade distributiva - a desigualdade social, que subsistiu, como ainda subsiste." BARROS, Sérgio Resende. Op. cit, p. 77.

${ }^{25}$ Acerca das características decorrentes da dimensão objetiva dos direitos fundamentais, ver SARMENTO, Daniel, Direitos Fundamentais... Op. cit., pp. 105-109 e CANOTILHO, J.J. Gomes Direito Constitucional Coimbra: Almedina, 1991, p. 545

${ }^{26}$ MENDES, Gilmar Ferreira, COELHO, Inocêncio Mártires e BRANCO, Paulo Gustavo Gonet, Op. cit., p. 256.
} 
se um problema de toda a sociedade, e não apenas do Estado. Para Daniel Sarmento, trata-se de uma "perspectiva comunitária dos direitos humanos",27.

Em contraposição ao paradigma liberal e à perspectiva meramente subjetiva dos direitos fundamentais, a dimensão objetiva desses direitos será responsável pelo reconhecimento de que ao Estado compete também uma postura ativa de proteção dessas prerrogativas, não sendo suficiente a mera posição de abstenção.

É também em decorrência dessa nova dimensão objetiva que se passa a atribuir às normas de direitos fundamentais um caráter concreto e de eficácia independente de qualquer regulamentação legislativa.

Por fim, é resultante da dimensão objetiva desses direitos o reconhecimento de que eles podem se autolimitar, no sentido de que muitas vezes esses direitos poderão entrar em choque e, a prevalecer o interesse da coletividade, um deles poderá limitar o outro.

Sendo assim, os direitos fundamentais não podem mais ser vistos sob uma perspectiva individualista, assumindo uma perspectiva coletiva; o que autoriza, com base neles, restrições a liberdades individuais, ao passo em que também enseja um dever de proteção - por parte do Estado - em relação ao cumprimento desses deveres.

\subsubsection{O paradigma social no segundo pós-guerra e os direitos fundamentais como ordem objetiva de valores}

No entanto, o constitucionalismo social também se mostrou falível quando, no segundo pós-guerra, comprovou-se o fracasso da constituição de Weimar e do nacional-socialismo alemão, momento em que, apesar do cumprimento estrito da Constituição, constatou-se que a observância apenas formal de seus dispositivos poderia levar a consequências drásticas para a população alemã, como aquelas observadas no fim da República e na ascensão do nacional-socialismo de Hitler.

${ }^{27}$ SARMENTO, Daniel. Direitos Fundamentais... Op. cit., p. 106 
Com esse fracasso, ao contrário da concepção adotada pela Constituição de Weimar, segundo a qual os direitos fundamentais eram considerados apenas como normas programáticas e princípios orientadores para os legisladores - que eram os únicos que poderiam atribuir, de fato, efeito a esses direitos -, as novas constituições passaram a adotar uma compreensão material dos direitos fundamentais, "com força normativa própria e eficácia direta, vinculando não só a comunidade mas também os poderes e os órgãos do Estado",28.

Essa nova concepção teórica pode ser constatada na Constituição de Bonn, de 1949, que passa a prever, dentre outras inovações, a aplicabilidade direta dos direitos fundamentais, tomando como parâmetro e base de fundamentação a inviolabilidade da dignidade humana. E sendo a dignidade humana inviolável, as normas dela decorrentes os direitos fundamentais - seriam imediatamente alçadas à condição de valores supremos de um ordenamento jurídico.

Assim, a antiga concepção dos direitos fundamentais como direitos públicos subjetivos é substituída por uma visão desses direitos como normas objetivas de princípios e decisões axiológicas ${ }^{29}$. Segundo essa visão, os direitos fundamentais não mais atuariam somente nas relações individuais entre cidadãos e Poder Público, tornandose os valores supremos a influenciar todo o ordenamento jurídico, em todos os seus níveis.

Importante marco na definição da dimensão objetiva dos direitos fundamentais foi o caso Lüth, julgado pela Corte Constitucional alemã em $1958^{30}$. Na análise da idoneidade do boicote promovido contra um filme produzido por um diretor de

\footnotetext{
${ }^{28}$ KAUFMANN, Rodrigo de Oliveira. Op. cit., p. 73

${ }^{29}$ Apesar de a maioria dos estudiosos entenderem como certa a progressão temporal entre o surgimento da dimensão subjetiva e posteriormente o da dimensão objetiva dos direitos fundamentais, André Rufino do Vale menciona posição doutrinária diversa: "No entanto, para Habermas, a mudança de um modelo liberal de concepção dos direitos fundamentais para o modelo do Estado Social de Direito só fez renascer o conteúdo objetivo, sempre presente no sistema dos direitos." VALE, André Rufino do Eficácia dos Direitos Fundamentais nas Relações Privadas. Porto Alegre: Sérgio Antonio Fabris Editor, 2004, pp. 7980

${ }^{30}$ Vide ALEXY, Robert. Teoría de los Derechos... Op.cit., p. 126. Ver também, a esse respeito, KAUFMANN, Rodrigo de Oliveira. Op. cit., p. 74-79, SARMENTO, Daniel. Direitos Fundamentais... Op. cit., p. 112-113, SARLET, Ingo Wolfgang, A Eficácia... Op. cit., p. 168. DIMOULIS, Dimitri e MARTINS, Leonardo. Teoria Geral dos Direitos Fundamentais. São Paulo: Editora Revista dos Tribunais, 2007, pp. 263-279, CANARIS, Claus-Wilhelm. Direitos Fundamentais e Direito Privado. Coimbra: Almedina, 2006, pp. 43-52 e 78-81; BRANCO, Paulo Gustavo Gonet. Juízo de Ponderação na jurisdição constitucional. São Paulo: Saraiva, 2009, p. 61.
} 
passado nazista, a Corte decidiu que as normas de direito civil apontadas como ilegitimamente violadas pela justiça de primeira instância deveriam ser interpretadas de acordo com os princípios constantes da Constituição, notadamente os direitos fundamentais.

Desse modo, a Corte assumiu que o sistema dos direitos fundamentais previsto na Constituição forma uma "ordem objetiva de valores" 31 , chegando a afirmar que "[e]ste sistema de valores, que se centra na dignidade da pessoa humana, em livre desenvolvimento dentro da comunidade social, deve ser considerado como uma decisão constitucional fundamental, que afeta a todas a esferas do direito público ou privado. "32

A partir dessa decisão, a Corte Constitucional alemã foi responsável pelo desenvolvimento de dois conceitos essenciais ao estudo dos direitos fundamentais, que são a sua eficácia irradiante ${ }^{33}$ e a teoria dos deveres de proteção ${ }^{34}$.

Segundo a ideia de eficácia irradiante dos direitos fundamentais, entendese que os valores representados por esses direitos têm influência em todo o ordenamento jurídico e devem condicionar a interpretação, aplicação e criação das normas, vinculando todos os poderes da República.

\footnotetext{
31 A esse respeito, Alexy cita o seguinte posicionamento do Tribunal Alemão: "De acuerdo con la jurisprudência permanente del Tribunal Constitucional Federal, las normas de derecho fundamental contienen no sólo derechos subjetivos de defensa del individuo frente al Estado, sino que representan, al mismo tempo, uns orden de valorativo objetivo que, en tanto decisión básica de derecho constitucional, es válida para todos los ámbitos del derecho y proporciona directrices e impulsos para la legislación, la administación y la jurisdicción (BVerfGE 39, 1 (41)" ALEXY, Robert. Teoría de los Derechos, Op. cit., p. 465. Ingo Wolfgang Sarlet, citando Alexy, comenta que a expressão "ordem objetiva de valores" pode ser entendida como um sinônimo de dimensão objetiva dos direitos fundamentais, assim como outras expressões como "sistema de valores, decisões constitucionais fundamentais, direitos fundamentais como normas objetivas, diretrizes e impulsos, etc.” SARLET, Ingo Wolfgang. Op. cit., p. 167.

${ }^{32}$ KOMMERS, Donald P. The Constitutional Jurisprudence of the Federal Republic of Germany. Durhan: Duke University Press, 1997.p. 363 apud SARMENTO, Daniel. Direitos Fundamentais... Op. cit., p. 112.

33 A respeito da eficácia irradiante dos direitos fundamentais, ver ALEXY, Robert. Teoría de los Derechos... Op. cit., pp. 465-483; SARMENTO, Daniel. Direitos Fundamentais... Op. cit., pp. 124-129; KAUFMANN, Rodrigo de Oliveira. Op. cit., pp. 78-79; SARLET, Ingo Wolfgang. A Eficácia... Op. cit., pp. 173-174

Diga-se que essa teoria pode ser dos deveres ou direitos de proteção. Será dos deveres de proteção quando olhada do ponto de vista estatal, e dos direitos de proteção, quando olhada do ponto de vista do cidadão titular do direito fundamental. A respeito da teoria dos deveres de proteção, ver ALEXY, Robert. Teoría de los Derechos... Op. cit., pp. 398-416; SARMENTO, Daniel. Direitos Fundamentais... Op. cit., pp. 129-138; KAUFMANN, Rodrigo de Oliveira. Op. cit., pp. 80-85; SARLET, Ingo Wolfgang. $A$ Eficácia... Op. cit., pp. 175-176.
} 
Robert Alexy, aliás, explicita três consequências diretas no ordenamento jurídico decorrentes da eficácia irradiante dos direitos fundamentais. Segundo ele, o primeiro desses efeitos seria o de que a Constituição delimitaria e determinaria materialmente o sistema jurídico, ao passo em que os direitos fundamentais nela previstos teriam que ser observados pelo ordenamento que se constituísse infraconstitucionalmente ${ }^{35}$.

Em decorrência desse primeiro fator, adviria a segunda consequência da eficácia irradiante, vinda dos juízos de ponderação típicos da aplicação e interpretação dos direitos fundamentais - que analisaremos detalhadamente em seguida. Sendo esse juízo de ponderação racional, mas imprevisível e dependente de fatores subjetivos, ele seria sempre de conformação aberta. Ou seja, o sistema jurídico condicionado materialmente pelos direitos fundamentais, seria também um sistema jurídico aberto ${ }^{36}$.

Por fim, esse sistema jurídico aberto traria questões de ordem moral enfrentadas pelos direitos fundamentais. E essas questões de ordem moral estariam principalmente vinculadas a princípios de justiça. Ou seja, ao final, a eficácia irradiante dos direitos fundamentais teria por consequência a injeção de valores de justiça em todos os âmbitos do direito ${ }^{37}$.

Já a teoria dos deveres de proteção prevê um novo papel para o Estado, que deixa de ser apenas o sujeito passivo das relações com os particulares para se tornar uma espécie de promotor e garantidor dos direitos fundamentais em todas as demais relações jurídicas existentes no âmbito da comunidade ${ }^{38}$.

\footnotetext{
${ }^{35}$ ALEXY, Robert. Teoría de los Derechos... Op. cit., pp. 481-482.

${ }^{36}$ ALEXY, Robert. Teoría de los Derechos... Op. cit., p. 482.

37 ALEXY, Robert. Teoría de los Derechos... Op. cit., pp. 482-483. É importante também lembrar que Alexy menciona a inclusão dos valores de justiça na teoria dos direitos fundamentais quando relaciona o argumento dos princípios como consequência necessária da superação da visão positivista e como decorrência lógica de uma conexão necessária entre direito e moral. ALEXY, Robert. Conceito e Validade do Direito. São Paulo: Martins Fontes, 2009. Pp. 85-86.

${ }^{38}$ Segundo a definição de Robert Alexy, “[p]or 'derechos de protección' habrán de entenderse aquí los derechos del titular de derecho fundamental frente al Estado para que éste lo proteja de intervenciones de terceros. Los derechos de protección pueden tener como objeto cosas muy diferentes. El espectro se extiende desde la protección, de tipo clásica, frente al homicidio, hasta la protección frente a los peligros del uso pacífico de la energía atómica. No solo la vida y la salud son posibles bienes protegidos, sino todo aquello que, desde el punto de vista de los derechos fundamentales, es digno de ser protegido, por ejemplo, la dignidad, la libertad, la familia y la propiedad. No menos variadas son las formas posibles de protección. Ellas comprenden, por ejemplo, la protección por medio de normas del derecho penal, de normas del derecho de la responsabilidad civil, de normas del derecho procesal, de acciones administrativas y por
} 
Vale dizer que esse papel ativo do Estado, consequência dos seus deveres de proteção, pode se dar de diversas formas, sendo a mais comum delas a aprovação de legislação que regulamente o direito fundamental em jogo.

Além disso, Alexy reforça que aos deveres de proteção do Estado devem sim ser reconhecidos correspondentes direitos subjetivos, uma vez que tais deveres dizem respeito a direitos individuais, os quais somente terão a força e eficácia que a Constituição permite atribuir-lhes se houver, de fato, o reconhecimento de que aos deveres de proteção do Estado correspondem direitos subjetivos dos cidadãos de exigirem a proteção desses direitos ${ }^{39}$.

Como resta claro, também a teoria do dever de proteção exerce importante influência na posição de supremacia dos direitos fundamentais, pois revertendo a posição passiva do Estado frente a esses direitos - característica de uma dimensão meramente subjetiva - permite que haja a promoção, proteção e aplicação dos direitos fundamentais de forma cada vez mais direta e eficaz, nas mais diversas esferas políticas de poder.

Por fim, vale mencionar que é também no período do segundo pós-guerra que surgem os direitos fundamentais de terceira geração, caracterizados por sua titularidade coletiva, indefinida e indeterminável. Como exemplos, podem-se citar o direito à paz, à autodeterminação dos povos, ao desenvolvimento e à qualidade de vida. No entanto, referidos direitos continuam em constante evolução e muitos deles só passaram a ser considerados de fato no período descrito a seguir ${ }^{40}$.

\subsection{A crise do paradigma social e o momento histórico atual}

medio de la actuación fáctica. Lo común detrás de esta variedad es que los derechos de protección son derechos subjetivos constitucionales frente al Estado para que éste realice acciones positivas fácticas o normativas que tienen como objeto la delimitación de las esferas de sujetos jurídicos de igual jerarquía, así como la exigibilidad judicial y la implementación de esta delimitación." ALEXY, Robert. Teoría de los Derechos... Op. cit., pp. 398-399.

${ }^{39}$ ALEXY, Robert. Teoría de los Derechos... Op.cit., pp. 400-404.

${ }^{40}$ Parte da doutrina advoga, ainda, a existência de direitos fundamentais de quarta geração, que seriam os direitos à democracia, à informação e ao pluralismo. Todos esses direitos seriam resultado da globalização e universalização dos direitos fundamentais. Nesse sentido, ver SARLET, Ingo Wolfgang A Eficácia... Op. cit., pp. 60-61. Contrariamente a essa quarta geração de direitos é a manifestação de FERREIRA FILHO, Manoel Gonçalves. Princípios Fundamentais do Direito Constitucional. São Paulo: Saraiva, 2010. p. 84. 
A globalização e as mudanças por ela ocasionadas na economia de mercado tornaram obsoleto o modelo de Estado Social, atualmente em crise ${ }^{41}$. O ente estatal, em virtude da assunção de diversas responsabilidades e da sua impossibilidade de cumprimento de todas as tarefas assumidas, passa a ser considerado ineficiente e o alto grau de dirigismo estatal será contestado por novos modelos.

O desenvolvimento da economia de mercado, notadamente no contexto de investimentos estrangeiros apátridas, contribui para a criação de um novo direito pelos agentes econômicos, que é basicamente lastreado em normas de mercado, de forma que "o ordenamento jurídico vai tornando-se policêntrico, permeado por regras engendradas por atores privados ou por entidades supranacionais" ${ }^{\prime 2}$.

O advento de um modelo neoliberal traz a preferência por constituições afinadas com o próprio paradigma liberal, ou seja, com mais normas de organização e limitação dos poderes estatais e menos normas programáticas e de direitos e garantias sociais e econômicos. Em consequência desse desenvolvimento, parte da doutrina afirma, inclusive, a extinção das constituições dirigentes ${ }^{43}$.

Progressivamente, portanto, o Estado intervencionista e atuante inspirado no paradigma social seria substituído por um Estado regulador e subsidiário, norteado pelo princípio da eficiência e preocupado com os resultados efetivos de suas ações.

No Brasil, apesar de a Constituição de 1988 ter um caráter social, diversas reformas constitucionais já realizadas demonstraram a necessidade de que referido diploma se adaptasse às novas concepções mundiais e diversos dispositivos notadamente aqueles relativos à ordem econômica nacional - foram relativizados a fim de permitir que o país não fosse excluído do desenvolvimento global, na expectativa de que um consistente progresso econômico pudesse naturalmente contribuir para um sólido desenvolvimento social.

\footnotetext{
${ }^{41}$ SARMENTO, Daniel. Direitos... Op. cit., pp. 26 e 27.

${ }^{42}$ SARMENTO, Daniel, Direitos Fundamentais... Op. cit., p. 30

${ }^{43}$ SARMENTO, Daniel, Direitos Fundamentais... Op. cit., p. 31. Vide ainda, a esse respeito: DANTAS, Miguel Calmon. Constitucionalismo Dirigente e Pós-Modernidade. São Paulo: Saraiva, 2009, pp. 344-347 e OLIVEIRA, Fábio Corrêa Souza de. Morte e Vida da Constituição Dirigente. Rio de Janeiro: Lumen Juris, 2010. pp. 80-83. Também no mesmo sentido, afirma Manoel Gonçalves Ferreira Filho que "está morta, e bem morta, a Constituição dirigente." FERREIRA FILHO, Manoel Gonçalves. Estado de Direito e Constituição, São Paulo: Saraiva, 2009, p. 69.
} 
Independentemente de análises valorativas acerca do novo modelo que ora se impõe, é necessário constatar que essas mudanças têm alterado não só o perfil estatal, como também o perfil constitucional a ele correspondente, que volta a se aproximar, na visão de alguns, dos modelos do paradigma liberal. E diante dessas diferenciações tão significativas, há quem advogue o nascimento de um novo paradigma, denominado póssocial $^{44}$.

Assim como no exemplo dos regulamentos de mercado citado acima, deixa de haver um monopólio estatal na produção de normas, o que as pode tornar carentes de legitimidade democrática. Muitas vezes, em determinados setores que exigem regulamentação e nos quais essa normatização é feita por meio de entes não-estatais, à opinião pública não é sequer dado espaço de participação, o que coloca em sério risco o respeito aos direitos e garantias fundamentais.

Dessa forma, Daniel Sarmento afirma que, se no paradigma liberal havia rígida dicotomia entre o público e o privado, substituída por uma publicização do privado no paradigma social, atualmente observa-se uma privatização do espaço público ${ }^{45}$. E ainda segundo ele, esse fator pode representar um risco para o respeito aos direitos fundamentais, na medida em que retira do poder público, democraticamente eleito, a exclusiva prerrogativa de criar as leis.

Vale apontar para registro, independentemente da nossa discordância com a tese, que alguns juristas brasileiros chegam até mesmo a defender que não há que se falar que o Brasil possa viver esse novo paradigma se sequer viveu de fato o paradigma social, uma vez que apenas as elites teriam se beneficiado de um Estado forte, o qual relegou a segundo plano a população em geral, que agora sim deveria usufruir de um

\footnotetext{
44 Todavia, a própria proximidade do momento atual com a fase de mudanças impede a afirmação categórica do surgimento de um novo paradigma. "Embora nos pareça que se trata de um modelo em construção, cujos contornos ainda não estão bem definidos já é possível, correndo certos riscos em razão da falta de distanciamento histórico, fotografar algumas das suas características mais marcantes, e analisar seu impacto sobre a nossa temática." SARMENTO, Daniel, Direitos Fundamentais... Op. cit., p. 5. Ainda no mesmo sentido é Miguel Dantas, que afirma: "De qualquer sorte, reconhece-se a dificuldade de identificação da sua consistência enquanto movimento, porque a referência ao prefixo conduz a uma reflexão sobre as condições de um passado ainda presente com vistas a uma antecipação de futuro no âmbito da incerteza e da fugacidade do presente, como também assinala Perry Anderson" DANTAS, Miguel Calmon. Op. cit., pp. 347-357.

45 SARMENTO, Daniel. Direitos Fundamentais... Op. cit., p. 34
} 
Estado cada vez mais atuante, a fim de fazer valer, efetivamente, o Estado Social no Brasil $^{46}$.

Todavia, na contramão desse entendimento estão doutrinadores que advogam a existência de uma crise da modernidade e o surgimento de um período que se poderia caracterizar, desde logo, como pós-modernidade ${ }^{47}$.

Mais ainda, o direito passa a ser visto, para alguns autores, como um sistema autopoiético $^{48}$, o que o reaproxima da visão formal do positivismo jurídico. Em consequência dessa visão, qualquer projeto de constituição dirigente é totalmente rechaçado, já que se advoga a elaboração de uma constituição meramente procedimental, alheia a sua dimensão substantiva.

Sendo assim, é evidente que o presente trabalho não adota a visão decorrente do pós-modernismo, pois apesar de haver estudos sobre esse novo modelo, ele ainda é controverso e não acreditamos possuir o distanciamento histórico necessário para defini-lo ou mesmo compreende-lo.

\footnotetext{
${ }^{46}$ Nesse sentido, forte em Boaventura de Sousa Santos, é o pensamento de STRECK, Lenio Luiz. Hermenêutica Jurídica E(m) Crise - Uma exploração hermenêutica da construção do Direito. Porto Alegre: Livraria do Advogado, 2009.

47 "Planeta Terra. Início do terceiro milênio. Ainda sem contato com outros mundos habitados. Entre luz e sombra, descortina-se a pós-modernidade. O rótulo genérico abriga a mistura de estilos, a descrença no poder absoluto da razão, o desprestígio do Estado. A era da velocidade. A imagem acima do conteúdo. O efêmero e o volátil parecem derrotar o permanente e o essencial. Vive-se a angústia do que não pôde ser e a perplexidade de um tempo sem verdades segurar. Uma época aparentemente pós-tudo: pós-marxista, póskelseniana, pós-freudiana." BARROSO, Luís Roberto. Interpretação e Aplicação da Constituição. São Paulo: Saraiva, 2007. pp. 305-306.

48 "Segundo esta perspectiva, o direito contemporâneo constituiria um sistema fechado em relação à sociedade. Desta clausura decorreria que é o próprio Direito quem define seus limites, selecionando o que é jurídico e o que não é, de acordo com seus critérios próprios. (...) Dentro dessa perspectiva autopoiética, a ideia de legitimidade do Direito é despida de colorações éticas e passa a fundar-se exclusivamente no procedimento. Direito legítimo é o direito positivado de acordo com as regras processuais estabelecidas em cada ordem jurídica.” SARMENTO, Daniel, Direitos Fundamentais... Op. cit., p. 42
} 


\section{DA INTERPRETAÇÃO E APLICAÇÃO DOS DIREITOS FUNDAMENTAIS}

Acima mostramos como os direitos fundamentais foram adquirindo importância com o desenvolvimento social e estatal e como eles modificaram o seu caráter e passaram a ser vistos como elementos de eficácia irradiante aos quais correspondiam direitos de proteção dos seus titulares. Verificamos, ainda, que a sua própria titularidade foi expandida, admitindo-se a sua aplicação nas mais diversas situações e não apenas em relações frente ao Estado.

Com isso, concluímos que os direitos fundamentais exercem um papel central no sistema jurídico, condicionando-o materialmente e servindo como parâmetro de validade para todas as normas hoje vigentes, podendo ser usado até mesmo como fundamento para invalidar uma norma democraticamente aprovada no Congresso Nacional.

Mas essas características práticas dos direitos fundamentais podem ser consideradas até mesmo consequência da conformação normativa desses direitos e das características específicas que os revestem de qualidades intrínsecas e diferenciadas de aplicabilidade, interpretação e eficácia.

E são precisamente esses aspectos que serão objeto de análise em seguida, os quais corroborarão para identificarmos, nos casos concretos selecionados, a postura adotada pelo Supremo Tribunal Federal na aplicabilidade desses direitos e a sua conformação teórica e efetividade prática na vida dos cidadãos brasileiros.

\subsection{Dos direitos fundamentais como princípios e da distinção entre princípios e regras}

Convencionou-se, no mundo jurídico acadêmico, classificar-se as normas entre regras e princípios, adotando, para tanto, critérios dos mais diversos. 
Intuitivamente, é claro, muitos critérios permeiam o nosso pensamento quando buscamos diferenciar regras e princípios, dentre eles a generalidade da norma, a sua aplicabilidade e influência no ordenamento em geral, o número de seus destinatários e até mesmo a forma com a qual é redigida.

No entanto, todos esses critérios não são objetivos e podem levar a confusões quando da análise concreta de normas, especialmente as constitucionais.

Por essa razão, Robert Alexy, que se debruça fortemente na análise dos direitos fundamentais e, também, no estudo da interpretação e aplicação dos princípios, aponta como critério definidor dessa distinção o fato de que princípios são normas que exigem que algo seja realizado na maior medida possível, tomando em consideração as possibilidades fáticas e jurídicas para que se lhe confira essa máxima eficácia ${ }^{49}$. Vale dizer que a análise do que é juridicamente possível será feita mediante o contraponto entre os princípios e regras aplicáveis a um mesmo caso concreto. As regras, por sua vez, não admitem essa eficácia gradativa e apenas podem ser ou não válidas, podem ser ou não aplicadas, não permitindo uma nuance em sua eficácia e aplicabilidade.

A forma mais eficaz de se constatar essa diferenciação na prática é o exame de como se solucionam conflitos entre regras e princípios. O conflito entre regras tende a ser dirimido por meio de juízos de validade entre as normas conflitantes, o qual pode se dar ou pela aplicação de uma exceção já prevista na própria norma em conflito, ou pela aplicação de máximas como aquelas que afirmam que lei posterior revoga anterior, ou até mesmo pela seleção de uma norma que se sobrepõe em termos de validade à outra.

Já o conflito de princípios deve ser solucionado de forma diversa e não implica um juízo de validade entre as normas conflitantes. Isso porque, como os princípios admitem eficácia gradual, a análise do conflito entre eles se dá no âmbito do peso $^{50}$ que cada qual assumirá num caso concreto e não no âmbito de sua validade, pois

\footnotetext{
49 "El punto decisivo para la distinción entre reglas y princípios es que los princípios son normas que ordenan que algo sea realizado en la mayor medida posible, dentro de las possibilidades jurídicas y reales existentes.” ALEXY, Robert. Teoría de los Derechos... p. 67.

50 "Los conflictos de reglas tienen lugar em la dimensión de la validez, mientras que las colisiones de principios - como quiera que solo pueden entrar en collision principios válidos - tienem lugar más allá de la
} 
não deixam ambos de ser válidos jamais. Assim, os princípios em conflito sempre terão igual status de validade se analisados abstratamente, mas no caso concreto um deles terá precedência sobre o outro.

Desse modo, na análise do conflito instaurado, será criada uma relação condicional de preferência entre os princípios, em que eles se excluirão mutuamente, mas será escolhido um deles para se sobrepor ao outro, levando em consideração a situação concreta e sempre preservando a máxima eficácia e extensão de cada um deles ${ }^{51}$.

Essa característica específica, que permite que a eficácia dos princípios se dê gradualmente sem que isso implique qualquer negativa de sua vigência, é o que os torna mandados de otimização ${ }^{52}$.

Além dessas características, Alexy ainda aponta outras que entende essenciais à diferenciação entre regras e princípios. Para ele, os princípios têm um caráter de exigência apenas prima facie, enquanto o caráter de exigência das regras são sempre definitivos. Isso significa que os princípios apontam em uma direção, mas não necessariamente indicam qual será a escolha ou interpretação correta e específica em um dado caso. As regras, por sua vez, já contêm um mandamento definitivo contido nelas mesmas, diferenciando-se nesse sentido ${ }^{53}$.

dimension de la validez, en la dimensión del peso.” ALEXY, Robert. Teoría de los Derechos... Op. cit., p. 71. Também ALEXY, Robert. La Teoría... Op. cit., pp. 45-46.

${ }^{51}$ A respeito da ideia de conflito entre princípios, é interessante observar que alguns juristas apontam como inexistentes autênticos conflitos entre direitos fundamentais, sob pena de se violar o princípio da unidade constitucional - se houvesse conflito, admitir-se-ia a aplicação de uma disposição da Constituição em detrimento de outra - e de que apenas poderia haver conflito se os direitos fundamentais pudessem ser aplicados de forma a trazer algum prejuízo, o que também seria uma contradição em termos. Nesse sentido, ver MARTÍNEZ-PUJALTE, Antonio-Luis e DOMINGO, Tomás de. Los derechos fundamentales en el sistema constitucional - Teoría general e implicaciones prácticas. Granada: Editorial Comares, 2011. pp. 76-79.

${ }^{52}$ Nesse ponto, optamos por adotar a concepção de Alexy sobre os princípios e assumimos, em consequência, que os direitos fundamentais podem ser considerados mandados de otimização. A despeito de Dworkin concordar em grande medida com a distinção feita por Alexy entre regras e princípios, ele não chega a admitir que os princípios são mandados de otimização. Sobre a definição de mandados de otimização, vide ALEXY, Robert. Conceito e validade do Direito, São Paulo: Martins Fontes, 2009, p. 85; ALEXY, Robert. Teoría de los Derechos... pp. 67-68 e ALEXY, Robert. Constitucionalismo discursivo. Porto Alegre: Livraria do Advogado, 2008. pp, 64-65. Ainda a respeito, vide SILVA, Virgílio Afonso da. Direitos Fundamentais - conteúdo essencial, restrições e eficácia. São Paulo: Malheiros, 2009. pp. 46-47.

${ }_{53}$ Aqui encontra-se mais uma diferença entre a teoria dos princípios de Alexy e Ronald Dworkin. Para Alexy, apesar de ser relevante essa diferença entre o caráter prima facie dos princípios e o caráter definitivo das regras, é possível vislumbrar exceções no que diz respeito às regras, especialmente quando da sua aplicação em casos concretos. Dworkin, por sua vez, parece não admitir essas matizações e adotar a diferenciação como quase absoluta. Vide ALEXY, Robert. Teoría de los Derechos... Op. cit., p. 80. 
Alexy alerta, também, que o intérprete não se deve deixar convencer da concepção ultrapassada de que os princípios motivam o estabelecimento de regras que, por sua vez, motivam os julgamentos dos casos concretos. Conforme alerta o autor, tanto as regras podem motivar outras regras, como os princípios podem servir eles mesmos como motivação para um julgamento concreto ${ }^{54}$. Daí, vale dizer, nasce a interpretação de que os princípios têm e devem ter eficácia direta e imediata na análise dos casos concretos, conforme sua concepção de componentes de uma ordem objetiva de valores, já esclarecida acima historicamente.

Vale apontar, aqui, que a teoria dos princípios e a sua diferenciação com as regras é também analisada por Ronald Dworkin em posicionamento que possui diversas semelhanças com o de Alexy, adotado por nós como parâmetro de análise futura.

Ronald Dworkin também aponta que os princípios têm um caráter de mandamentos meramente prima facie ${ }^{55}$ enquanto as regras possuem um caráter definitivo $^{56}$. Da mesma forma, admite o autor norte-americano que a aplicação dos princípios é dependente de um juízo de ponderação, uma vez que não se pode negar validade a um princípio quando em confronto com outro ${ }^{57}$. Todavia, Dworkin recusa-se a aceitar, por exemplo, que uma regra pode perder o seu caráter definitivo diante de um caso concreto, ao contrário do que admite Alexy, no sentido de que até mesmo um

\footnotetext{
${ }^{54}$ ALEXY, Robert. Teoría de los Derechos...Op. cit., p. 83.

55 "Mas não é assim que funcionam os princípios apresentados como exemplos nas citações. Mesmo aqueles que mais se assemelham a regras não apresentam consequências jurídicas que se seguem automaticamente quando as condições são dadas.” DWORKIN, Ronald. Levando... Op. cit., p. 40.

56 “As regras são aplicáveis à maneira do tudo-ou-nada. Dados os fatos que uma regra estipula então ou a regra é válida, e neste caso a resposta que ela fornece deve ser aceita, ou não é válida, e neste caso em nada contribui para a decisão." DWORKIN, Ronald. Levando... Op. cit., p. 39. Também a respeito da tese dworkiana de "separação rigorosa" entre regras e princípios, vide ALEXY, Robert. Direito, Razão, Discurso. Estudos para a filosofia do direito. Porto Alegre: Livraria do Advogado, 2010. pp. 144-147. No mesmo sentido é BARCELLOS, Ana Paula de. Op. cit., pp. 70-78 e SILVA, Virgílio Afonso da. Op. cit., pp. 49-56.

57 "Quando os princípios se intercruzam (por exemplo, a política de proteção aos compradores de automóveis se opõe aos princípios de liberdade do contrato), aquele que vai resolver o conflito tem de levar em conta a força relativa de cada um. Esta não pode ser, por certo, uma mensuração exata e o julgamento que determina que um princípio ou uma política particular é mais importante que outra frequentemente será objeto de controvérsia. Não obstante, essa dimensão é uma parte integrante do conceito de um princípio, de modo que faz sentido perguntar que peso ele tem ou quão importante ele é." DWORKIN, Ronald. Levando... Op. cit., pp. 42-43.
} 
princípio pode acabar por excepcionar uma regra até então de caráter aparentemente definitivo $^{58}$.

Outra diferença entre as duas teorias que é importante estabelecer é o fato de que Dworkin limita os princípios àquelas normas que sirvam como razão/motivação de direitos fundamentais, diferenciando-as daquelas que têm por objeto bens coletivos -as quais denominará de políticas. Não obstante a relevância da distinção entre os direitos individuais e os coletivos, ambas as normas, no nosso entender e acompanhando o pensamento de Alexy, possuem caráter de princípio e estão sujeitas às mesmas técnicas de interpretação e aplicação, mormente porque os bens coletivos não deixam de ser, em última instância, parte do patrimônio individual ${ }^{59}$.

Porém, mais interessante ainda é a distinção de que, para Dworkin, o sistema de princípios e regras permite sempre encontrar uma única solução correta para o problema enfrentado, o que é rechaçado por Alexy, que acredita que a única solução correta apenas seria possível se fossem criadas listas definitivas que abrangessem todos os princípios possíveis e se entre eles já houvesse uma hierarquia preestabelecida, o que não há.

Ronald Dworkin desenvolve seu raciocínio primeiramente contrapondo-se à ideia positivista no sentido de que, na ausência de normas para regular a matéria, deverse-ia permitir ao juiz da causa uma discricionariedade máxima que lhe permitisse encontrar a solução no caso concreto inclusive com a aplicação de normas supralegais ${ }^{60}$.

Para ele, não se pode admitir que para um mesmo caso existam diversas decisões corretas possíveis, sob pena de se autorizar excessivo ativismo judicial e de se instaurar insegurança jurídica inaceitável no seio social ${ }^{61}$. Dessa forma, ele advoga que existe sim uma única solução correta, mas que ela é de difícil percepção e deve levar em consideração todos os fatores jurídicos e fáticos que envolvem a controvérsia em questão,

\footnotetext{
${ }^{58}$ A esse respeito, vide ALEXY, Robert. Teoría de los Derechos... Op. cit., p. 80.

59 Vide ALEXY, Robert. Teoría de los Derechos... Op. cit., p. 91. E também DWORKIN, Ronald. Levando... Op. cit., pp. 35-46.

${ }^{60}$ DWORKIN, Ronald. Levando... Op. cit. pp. 108-113.

${ }^{61}$ Sobre a única decisão correta de Dworkin, vide explicação de BELLO FILHO, Ney de Barros. Sistema Constitucional Aberto. Belo Horizonte: Del Rey, 2003, pp. 98-102.
} 
nomeando, para realizar essa interpretação, um juiz sobre-humano ${ }^{62}$ que denomina de Hércules $^{63}$.

O método interpretativo utilizado por Hércules para chegar à única solução correta e possível para o caso concreto é equiparado, por Dworkin, à elaboração de um "romance em cadeia" ${ }^{64}$, o que significa que o autor admite que a solução correta deve levar em consideração capítulos escritos por outros juízes Hércules ao longo do tempo, bem como pelos legisladores e membros do Executivo que tiveram relação com aquelas normas aplicáveis no caso concreto, de modo que a solução correta é perquirida levandose em consideração todos esses aspectos passados e presentes e, portanto, pode ser que ela seja alterada futuramente, quando um novo juiz Hércules tenha que analisar a mesma situação diante de um novo contexto social que requeira a elaboração de um novo capítulo desse romance em cadeia.

Já para Alexy, é incoerente a posição de Dworkin de que existe uma única solução correta, pois é impossível para ele, como adiantamos acima, que se crie uma definição prévia que abarque todos os princípios que possam estar envolvidos em uma causa, bem como todas as suas possíveis interpretações e até hierarquizações quando em conflito, sendo certo que a decisão mais adequada ao caso concreto -- e veja, não a única decisão correta ao caso -- somente poderá ser encontrada pelo uso do método da ponderação, que analisaremos em seguida e que norteará a análise desse trabalho.

Reitera Alexy que é impossível a única resposta correta, pois não se vislumbra, na realidade prática, uma situação em que haja efetivo consenso e que, se a resposta encontrada fosse a única correta, tal consenso certamente se verificaria na prática.

Contudo, acredita o autor que a proposta de única solução correta pode ter a sua utilidade se usada como um parâmetro de definição interpretativa, segundo o qual o

\footnotetext{
62 "O leitor entenderá agora por que chamei nosso juiz de Hércules. Ele deve construir um esquema de princípios abstratos e concretos que forneça uma justificação coerente a todos os precedentes do direito costumeiro e, na medida em que estes devem ser justificados por princípios, também um esquema que justifique as disposições constitucionais e legislativas.” DWORKIN, Ronald. Levando... Op. cit., p. 182.

${ }^{63}$ DWORKIN, Ronald. Levando... Op. cit. pp. 164-192.

${ }^{64}$ DWORKIN, Ronald. O Império do Direito. São Paulo: Martins Fontes, 2007. pp. 275-279.
} 
intérprete se esforçaria ao máximo para fundamentar racionalmente a sua posição final como se ela fosse a única posição correta ${ }^{65}$.

Portanto, definidos os parâmetros que diferenciam princípios de regras e diante do conhecimento que temos das normas de direitos fundamentais constitucionalmente previstas, é fácil concluir que os direitos fundamentais configuramse como princípios e, como tais, possuem todas as características acima já delineadas e analisadas.

E em virtude das características especiais de que se revestem os princípios e os direitos fundamentais, eles estão sujeitos a técnicas específicas de interpretação, as quais analisaremos em seguida para que possamos, posteriormente, verificar como se dá, pelo Supremo Tribunal Federal, a aplicação dessas técnicas aos casos concretos relativos a direitos fundamentais.

\subsection{A interpretação e aplicação dos direitos fundamentais aos casos concretos -- a racionalidade da argumentação jurídica com base na teoria do discurso de Alexy}

Quando analisamos as diferenças entre as teorias de Dworkin e Alexy a respeito da distinção entre princípios e regras, tivemos a oportunidade de examinar brevemente a teoria de interpretação desses direitos proposta por Dworkin e a rechaçamos para afirmar, desde então, nossa vinculação à técnica de ponderação nos moldes que mais se assemelham ao modelo de Alexy.

$\mathrm{Na}$ tentativa de dotar o sistema interpretativo dos princípios da racionalidade cuja suposta falta lhe rende as maiores críticas, Alexy busca construir uma teoria da argumentação jurídica baseada na teoria do discurso ${ }^{66}$. Para ele, os diferentes tipos de discussão jurídica - discussão científica e dogmática, decisões judiciais, discussões no âmbito legislativo - podem ainda ser subdivididos em categorias comuns, como aquelas que são institucionalizadas, por exemplo, ou aquelas que são

\footnotetext{
${ }^{65}$ Nesse sentido é BRANCO, Paulo Gustavo Gonet. Juizo de ... Op. cit., pp. 158-159.

${ }^{66}$ ALEXY, Robert. Teoria da Argumentação Jurídica - A teoria do discurso racional como teoria da justificação jurídica. São Paulo: Landy, 2005. Também a respeito dessa teoria de Alexy, em excelente síntese, vide BRANCO, Paulo Gustavo Gonet. Juizo de Ponderação... Op. cit., pp. 157-166.
} 
temporalmente limitadas, ou ainda as que produzem efeitos vinculantes e as que têm mero efeito científico e de análise.

O aspecto comum a todas, contudo, é que elas argumentam juridicamente, e isso significa que elas argumentam de forma vinculada ao direito vigente ${ }^{67}$.

\subsubsection{Da pretensão de correção no discurso jurídico}

Toda decisão judicial é, como se sabe, submetida à exigência de fundamentação, pelo próprio direito positivo (no caso do Brasil, pelo artigo 93, IX, da Constituição Federal $^{68}$ ). Essa exigência de fundamentação, conforme já havíamos notado anteriormente, está intimamente ligada com a pretensão de correção que se deve observar em todas as decisões judiciais, sob pena de não se justificarem moralmente essas decisões, ainda que possam mesmo assim produzir seus efeitos.

A justificação moral das decisões, decorrente de sua pretensão de correção, influi na legitimidade da decisão e condiciona a sua aceitação ${ }^{69}$.

O discurso jurídico, contudo, enfrenta diversas limitações para atingir essa pretensão de correção, facilmente perceptíveis nas decisões judiciais. Dentre essas limitações podemos apontar os interesses divergentes das partes, a busca pelo mais vantajoso ao invés da busca pelo mais justo, os limites de prazo e também as disposições processuais $^{70}$.

\footnotetext{
${ }^{67}$ ALEXY, Robert. Teoria da Argumentação...Op. cit., pp. 209-211.

${ }^{68}$ Art. 93. Lei complementar, de iniciativa do Supremo Tribunal Federal, disporá sobre o Estatuto da Magistratura, observados os seguintes princípios: (...)

IX todos os julgamentos dos órgãos do Poder Judiciário serão públicos, e fundamentadas todas as decisões, sob pena de nulidade, podendo a lei limitar a presença, em determinados atos, às próprias partes e a seus advogados, ou somente a estes, em casos nos quais a preservação do direito à intimidade do interessado no sigilo não prejudique o interesse público à informação;

${ }^{69}$ ALEXY, Robert. Teoria da Argumentação... Op. cit. pp. 212-215.

${ }^{70}$ A questão que então se formula é se essas limitações desnaturam a natureza de discurso do chamado discurso jurídico, já que, na teoria do discurso, as comunicações devem ocorrer sem coerção e sem restrições. Contudo, mesmo que o discurso jurídico não esteja livre nem de coerção e nem de restrição, pode-se dizer que ele se enquadra nessa teoria exatamente porque, no processo, as partes sempre buscam fundamentar suas alegações com uma pretensão de correção. Assim, pretendem elas que qualquer ser racional vincule-se à argumentação que por elas foi desenvolvida.
} 
Daí, conclui Alexy, que a pretensão de correção também pode ser encontrada no discurso jurídico, ainda que ela tenha, nele, um significado diferente daquele que possui no discurso prático geral, já que, no discurso jurídico, aceita-se que as questões possam ser racionalmente fundamentadas, ainda que as proposições normativas não se revistam de racionalidade em si mesmas.

\subsubsection{A fundamentação jurídica -- justificação interna e externa}

Portanto, afere-se que a pretensão de correção está intimamente ligada a uma fundamentação racional das decisões judiciais no ordenamento jurídico. E essa fundamentação racional das decisões jurídicas depende de sua justificação interna (relação lógica entre as premissas da decisão e a própria decisão, ou “silogismo jurídico") e externa (quanto à correção das premissas) ${ }^{71}$.

Quanto à justificação interna, Alexy destaca dois pontos necessários à fundamentação jurídica: a existência de uma norma universal (que deve ser aplicada, ainda que com outras proposições) e a derivação lógica que a decisão jurídica deve ter dessa norma universal, em raciocínio silogístico.

Mas essa fundamentação silogística não é aplicável aos casos complicados, como quando há diversas interpretações e consequências possíveis, ou quando a aplicação da norma jurídica exige uma norma complementar, por exemplo.

Nesses casos, sempre que houver dúvida sobre o enquadramento de um fato concreto em uma das premissas das quais logicamente decorrerá a decisão judicial, deverá ser apresentada uma nova regra que decida a dúvida suscitada. E essa regra há de ser construída em quantas etapas de desenvolvimento forem necessárias para esclarecer progressivamente o caso em análise, ainda que elas sejam muitas. E para tanto, é necessário entrar com profundidade na análise dos fatos e não apenas na das normas.

Dessa forma, o processo de justificação interna das decisões jurídicas pelos órgãos decisórios fica dividido em duas etapas: descobrimento e justificação. A

${ }^{71}$ ALEXY, Robert. Teoria da Argumentação... Op. cit., pp. 217-227. 
etapa de descobrimento, que se relaciona com os fatos e as hipóteses normativas, é influenciada pela etapa posterior de justificação. E o processo da justificação contribui para a segurança jurídica e a justiça na medida em que torna explícitas as premissas utilizadas na tomada de uma decisão, facilitando a sua análise e crítica.

A justificação externa, por sua vez, diz respeito à fundamentação das premissas utilizadas na justificação interna, e pode se basear tanto em regras de direito positivo, quanto em enunciados empíricos, ou até mesmo em nenhuma das duas coisas em questão.

A fundamentação externa por meio das regras de direito positivo consiste na demonstração de seu caráter de validade. A fundamentação externa por meio dos fatos empíricos $^{72}$ consiste em presunções racionais e até regras de ônus probante. E as premissas que não se classificam nem em um e nem em outro desses grupos são fundamentações externas feitas por meio da argumentação jurídica. Todas elas, contudo, têm interconexões e são sempre aplicadas conjuntamente na definição do método interpretativo de todos os tipos de premissas.

No entanto, Alexy fixa-se na justificação externa do terceiro tipo dessas premissas, por ser aquele que origina propriamente, de forma purista, a argumentação jurídica. Ele divide, então, seis tipos de regras e formas de justificação externa: (i) lei, ou interpretação; (ii) Ciência do Direito, ou dogmática; (iii) precedente; (iv) razão, ou argumentação prática geral; (v) empiria; e (vi) formas especiais de argumentos jurídicos ${ }^{73}$.

\subsubsection{A justificação externa por meio da argumentação jurídica -- lei e interpretação}

Definidas as formas de justificação externa, Alexy busca demonstrar como cada uma delas funciona na prática.

\footnotetext{
${ }^{72}$ A argumentação empírica, segundo o autor, está presente em quase todas as formas de argumentação jurídica, pois é indiscutível a importância dos fatos para as decisões jurídicas. Só que a argumentação empírica não é precisa e envolve uma necessária cooperação interdisciplinar, e também a realização de juízos racionais de presunção.

${ }_{73}^{7}$ ALEXY, Robert. Teoria da Argumentação... Op. cit., pp. 227-273.
} 
Assim, analisando primeiramente a justificação externa por meio da lei e da interpretação, nomeia seis categorias em que se dividem os argumentos interpretativos dessa espécie: (i) semântica; (ii) genética; (iii) histórica; (iv) comparativa; (v) sistemática; e (vi) teleológica ${ }^{74}$.

O argumento semântico é aquele que, por meio da linguagem, quer mostrar que uma dada interpretação é possível. Ele pode se dar de forma peremptória, afirmando que certa interpretação é ou não é alguma coisa, ao mesmo tempo que pode apenas revelar uma possibilidade de interpretação. Portanto, nas duas primeiras hipóteses, o argumento semântico pode ser suficiente para a fundamentação de uma decisão jurídica, enquanto que, na última hipótese, ela reflete apenas uma possibilidade de aplicação $^{75}$.

Nos casos em que o argumento semântico não se mostra suficiente, utilizam-se outros tipos de argumentos interpretativos. Um deles é o argumento genético, que parte do pressuposto do desejo do legislador, que pode tanto ser a sua vontade propriamente dita, quanto a intenção de se chegar a um fim específico (o que também pode ser considerado como uma espécie de interpretação teleológica $)^{76}$.

$\mathrm{Na}$ concretização do argumento genético, devem haver enunciados que exprimem a vontade do legislador, a fim de cumprir o requisito de saturação. No entanto, o cumprimento desse requisito é muito dificultado, por exemplo, pela impossibilidade de se determinar o sujeito da vontade expressa nos enunciados genéticos.

Os argumentos históricos, por sua vez, dizem respeito à história do problema jurídico colocado e tratam de perquirir as diferentes formas de solução que já foram atribuídas a esse problema e as consequências que de cada uma dessas decisões já emergiu $^{77}$. É similar, embora mais complexo, o argumento comparativo, pois ao invés de

\footnotetext{
${ }^{74}$ ALEXY, Robert. Teoria da Argumentação... Op. cit., p. 230.

${ }^{75}$ ALEXY, Robert. Teoria da Argumentação... Op. cit., pp. 230-231.

${ }^{76}$ ALEXY, Robert. Teoria da Argumentação... Op. cit., pp. 232-234.

${ }^{77}$ ALEXY, Robert. Teoria da Argumentação... Op. cit., pp. 234-235.
} 
analisar o passado histórico do problema jurídico em si, ele faz um exame comparativo com outras sociedades ${ }^{78}$.

O argumento sistemático trata da relação lógica entre normas - sua pertinência dentro do sistema jurídico e sua relação com as demais normas, fins e princípios do ordenamento $^{79}$. A forma mais comum desse argumento é a da contradição normativa, quando se observa que uma norma conflita com outra e que, desse modo, algum sentido de sua interpretação não deve prevalecer, sob pena de tornar uma outra norma inválida.

Por fim, a argumentação teleológica é aquela que se liga a uma finalidade ${ }^{80}$. Essa argumentação é objetiva quando não se refere a fins pessoais, mas sim a fins racionais, e que estejam prescritos no contexto do ordenamento vigente. Tais fins têm um sujeito hipotético e se viabilizam por meio de uma argumentação racional.

Muitas vezes, o argumento teleológico depende de uma argumentação empírica, assim como, em outras tantas vezes, suas regras refletem não só uma finalidade possível, mas várias, o que faz nascer a necessidade do exercício de um juízo de preferência, seguido por um juízo de limitações recíprocas.

O campo de aplicabilidade desses seis cânones jurídicos se dá, particularmente, no conflito de normas, na restrição de seu campo de aplicação e na sua fundamentação. O seu status lógico não é propriamente o de regras e nem apenas o de indicativos de direção. Trata-se, na verdade, de esquemas (ou formas) de argumentos, que estruturam o ordenamento jurídico.

E apenas se pode considerar um argumento completo se ele atende ao requisito de saturação, ou seja, se ele contém todas as suas possíveis premissas, empíricas ou normativas. E será precisamente o cumprimento do requisito de saturação que irá assegurar a racionalidade no uso dos cânones ${ }^{81}$.

\footnotetext{
${ }^{78}$ ALEXY, Robert. Teoria da Argumentação... Op. cit., p. 235.

${ }^{79}$ ALEXY, Robert. Teoria da Argumentação... Op. cit., p. 235.

${ }^{80}$ ALEXY, Robert. Teoria da Argumentação... Op. cit., pp. 235-239.

${ }^{81}$ ALEXY, Robert. Teoria da Argumentação... Op. cit., p. 243.
} 
Ainda, cada uma das formas de argumentação tem uma função própria e principal, de modo que, na construção de uma decisão jurídica, todas elas se interrelacionam. Da mesma maneira, isso gera uma insegurança no uso dos cânones, pois a aplicação das diferentes formas pode levar a soluções diversas para um mesmo problema; o que, como vimos, não chega a ser um paradoxo para a teoria de Alexy, já que ela admite não existir uma única resposta correta, apesar de frisar o fato de que o intérprete deverá sempre buscar a pretensão de correção, sob pena de enfraquecer o seu discurso jurídico.

Enfim, a teoria do discurso não oferece uma solução aos problemas jurídicos, mas apresenta uma melhoria, na medida em que mostra as possibilidades de uso das diferentes formas de argumentação. No entanto, Alexy propõe que os argumentos semânticos e históricos tenham, em geral, maior peso que os demais, os quais apenas poderão se sobrepor caso apresentem motivação racional suficiente. E esse juízo é livre para qualquer intérprete, desde que ele argumente racionalmente. Além disso, o juízo entre os argumentos que serão utilizados e que deverão se sobrepor nos casos específicos deverá ser feito por meio de ponderação.

\subsubsection{A justificação externa por meio da argumentação dogmática}

Seguindo a construção de uma teoria de argumentação jurídica fundada na teoria do discurso, Alexy defende a argumentação dogmática e a sua importância para a racionalidade da fundamentação jurídica.

Para tanto, esclarece que: (i) a dogmática jurídica é um conjunto de enunciados; (ii) esses enunciados estão relacionados com a Jurisprudência e com a legislação; (iii) também eles formam um todo coerente; (iv) e dessa forma, se legitimam em uma Ciência do Direito institucionalizada, que é a característica que os diferencia dos enunciados práticos de tipo geral; e (v) a dogmática tem conteúdo normativo ${ }^{82}$.

\footnotetext{
82 "Da síntese das exigências contidas nestas cinco condições resulta a seguinte definição: uma dogmática do Direito é (1) uma série de enunciados que (2) se referem à legislação e à aplicação do Direito, mas que não se podem identificar com sua descrição, (3) estão entre si numa relação de coerência mútua, (4) formam-se e discutem dentro de uma Ciência do Direito que funciona institucionalmente e (5) têm conteúdo normativo.” ALEXY, Robert. Teoria da Argumentação... Op. cit., p. 249
} 
E com base nessa definição, Alexy conclui que são enunciados dogmáticos aqueles conceitos jurídicos genuínos, que dizem respeito a fatos institucionalizados, como contrato ou legítima defesa, por exemplo. Aponta, ainda, que devem também ser considerados enunciados dogmáticos aqueles que expressam normas não extraídas da lei, desde que haja um certo consenso entre os juristas a esse respeito. Por fim, considera como enunciados dogmáticos as descrições e caracterizações de estados de coisas e a formulação de princípios.

A argumentação dogmática é pura quando se utiliza de enunciados dogmáticos e também de enunciados empíricos e de normas jurídico-positivas. Por outro lado, ela é impura quando necessita, para se completar, do uso de argumentos práticos gerais.

A fundamentação e comprovação de enunciados dogmáticos se dá não só por meio de enunciados empíricos e de normas jurídicas, mas também e, principalmente, por meio de outros enunciados dogmáticos. Esse regresso ao infinito na origem da fundamentação leva, ao fim, a uma fundamentação com base em argumentos práticos do tipo geral.

E essa fundamentação final em argumentos práticos do tipo geral mostra que os enunciados dogmáticos não são irrefutáveis, de forma que não caracterizam dogmas no sentido estrito da palavra ${ }^{83}$.

Não só a fundamentação, mas também a comprovação dos referidos enunciados tem como base os próprios enunciados dogmáticos. E essa comprovação pode se dar em um sentido amplo ou estrito e sempre de forma sistemática. No sentido estrito, verifica-se se os enunciados dogmáticos e as normas jurídicas são logicamente compatíveis entre si; enquanto no sentido amplo, verifica-se se as decisões baseadas nesses enunciados estão corretamente fundamentadas em enunciados práticos gerais. E a superação dessas comprovações sistemáticas - ambas - são necessárias para a aceitabilidade dos referidos enunciados.

${ }^{83}$ ALEXY, Robert. Teoria da Argumentação... Op. cit., p. 257. 
Diante disso, surge a dúvida da real necessidade da argumentação dogmática diante da argumentação prática geral que sempre a fundamenta em última instância ${ }^{84}$. Para saná-la o autor examina seis funções atribuídas à dogmática: (i) de estabilização; (ii) de progresso; (iii) de descarga; (iv) técnica; (v) de controle; e (vi) heurística $^{85}$.

A função de estabilização decorre primeiramente da característica institucional da dogmática e do fato de que seus enunciados criam soluções reproduzíveis que, de acordo com o princípio da inércia, sujeitam ao pesado ônus de argumentação aquele que queira refutar um enunciado dogmático já devidamente estável.

Relacionando-se com a função de estabilização, encontra-se a de progresso, igualmente derivada da ampliação da discussão dogmática. Também decorrente desse caráter de estabilização é a função de descarga, que exime os aplicadores do encargo de nova e extensa fundamentação de um problema jurídico, tendo em vista a possibilidade de reprodução de decisões já previamente tomadas com base em enunciados dogmáticos.

A função técnica da dogmática está ligada com o seu caráter de informação e de disseminação do ensino jurídico. Já a função de controle, conforme já adiantado, permite que se decida os casos não de maneira isolada, mas relacionados com o sistema como um todo e por meio de um juízo de compatibilidade sistemático. Essa função relaciona-se ainda com a função heurística, que diz respeito à formação de modelos de solução, distinções e pontos de vista, que somente são possíveis de serem formados tendo em vista a sistematização do direito vigente.

\subsubsection{A justificação externa pelo uso dos precedentes}

Após analisar os argumentos dogmáticos e as regras e formas de interpretação das leis como as duas primeiras formas de justificação externa, o autor

\footnotetext{
84 “A argumentação dogmática não pode, por isso, se reduzir à argumentação prática geral, mas a argumentação prática geral constitui a base da argumentação dogmática”. ALEXY, Robert. Teoria da Argumentação... Op. cit., p. 256.

${ }^{85}$ ALEXY, Robert. Teoria da Argumentação... Op. cit., pp. 258-262.
} 
passa à análise do uso dos precedentes ${ }^{86}$. Aqui, Alexy aponta duas questões que entende fundamentais: (i) o papel da observância dos precedentes dentro do esquema da teoria do discurso; e (ii) a relação entre os argumentos baseados em precedentes e os demais argumentos utilizados no discurso jurídico.

Inicialmente, Alexy prega que a superação dos precedentes implica uma alta carga de argumentação ao intérprete. Para tanto, afirma que jamais existirão casos idênticos e que, por essa razão, sempre haverá a possibilidade de se argumentar contra o precedente. De qualquer maneira, é inevitável a afirmativa de que o precedente cria uma inércia em seu favor e que, dessa forma, aquele que quer bater de frente com o precedente deve encarar e assumir o encargo da argumentação, tendo em vista que a segurança jurídica e a proteção da confiança não são os únicos valores a serem protegidos pelo sistema jurídico ${ }^{87}$.

O uso do precedente e da argumentação jurídica depende das possibilidades que a situação concreta oferece. Levando-se em consideração que a aplicação do precedente pressupõe a aplicação da norma que foi utilizada no referido precedente, podemos dizer que a carga da argumentação que compete àquele que quer se afastar do cumprimento desse precedente diz respeito à tentativa de não se fazer aplicar referida norma ao caso que está defendendo.

Para tanto, duas técnicas podem ser utilizadas. A primeira, de distinguishing, pressupõe não a superação do precedente original, mas a demonstração de características peculiares que tornam o caso em questão diverso daquele que originou o precedente. Já o overruling pressupõe a superação do precedente, tendo em vista razões de mudança de valoração nas circunstâncias examinadas, as quais apresentam semelhanças fáticas inquestionáveis. Ambas as técnicas, deve-se dizer, pressupõem fundamentação racional.

\subsubsection{A justificação externa por meio de argumentos jurídicos especiais e de argumentos práticos}

\footnotetext{
${ }^{86}$ ALEXY, Robert. Teoria da Argumentação... Op. cit., pp. 264-268.

${ }^{87}$ ALEXY, Robert. Teoria da Argumentação... Op. cit., pp. 265-267.
} 
Passa o autor, finalmente, ao estudo do uso de formas de argumentos jurídicos especiais também como hipóteses de fundamentação externa, citando como exemplos a analogia e o argumentum a contrario, a fortiori ou ad absurdum ${ }^{88}$. Para ele, todas essas formas de argumento são inferências logicamente válidas, o que não as exime de terem todas as suas premissas devidamente fundamentadas, sob pena de inconsistência em sua aplicação. Daí afirmar, o autor, que os argumentos jurídicos especiais também precisam atender ao requisito de saturação, decorrente da suficiente e completa fundamentação racional.

De todo o exposto, verificado o papel dos argumentos práticos na justificação externa de um discurso racional, Alexy sintetiza da seguinte forma a sua participação no discurso jurídico, ressaltando serem eles o fundamento da argumentação jurídica:

\footnotetext{
“A argumentação prática geral pode ser necessária (1) na fundamentação das premissas normativas requeridas para a saturação das diferentes formas de argumentos, (2) na fundamentação da eleição de diferentes formas de argumentos que levam a diferentes resultados, (3) na fundamentação e comprovação de enunciados dogmáticos, (4) na fundamentação dos distinguishing e overruling e (5) diretamente na fundamentação dos enunciados a serem utilizados na justificação interna. (p. 273)
}

Feitas as considerações acima sintetizadas, o autor passa à análise mais estreita da relação entre o discurso prático geral e o discurso jurídico.

\subsubsection{O discurso prático geral e sua relação com o discurso jurídico}

Primeiramente, na tentativa de relacionar o discurso jurídico com o discurso prático geral, Alexy volta a afirmar a necessidade do discurso jurídico, ainda que já exista o discurso prático geral e ainda que ambos sejam absolutamente relacionados. Explica que essa necessidade decorre da debilidade das regras e formas do discurso prático geral e da inexistência de uma determinação ou direção das normas que devem ser utilizadas na elaboração de uma decisão final.

Portanto, o discurso jurídico, apesar de também sofrer de vagueza de suas normas e ainda de poder enfrentar questões como conflitos normativos, inexistência de

${ }^{88}$ ALEXY, Robert. Teoria da Argumentação... Op. cit., pp. 268-273. 
prévia regulação normativa e até necessidade prática de se decidir de forma contrária ao direito posto, reforça a fundamentação advinda do discurso prático geral e a complementa, diminuindo suas debilidades e reforçando a racionalidade das decisões daí decorrentes.

Percebe-se, entre os dois tipos de discurso, uma coincidência parcial no que diz respeito à pretensão de correção ${ }^{89}$. No discurso jurídico, essa pretensão decorre da possibilidade de haver uma fundamentação racional no âmbito do ordenamento jurídico vigente. E essa possibilidade está condicionada à racionalidade da própria legislação, o que leva a questionamentos acerca do legislador e da própria sociedade.

Há, ainda, uma coincidência estrutural entre regras e formas de ambos os discursos ora em estudo ${ }^{90}$. Essa coincidência é apontada em seis aspectos diversos por Alexy: (i) as regras e formas de justificação interna se submetem, sempre, ao princípio da universalidade; (ii) a argumentação empírica, nos dois casos, sempre apresenta papel de extrema relevância; (iii) algumas formas de argumento, como os cânones, têm caráter vinculante racional à argumentação; (iv) a Ciência do Direito dogmática é a institucionalização argumentativa que estabiliza o discurso prático no contexto da existência de um ordenamento jurídico; (v) também o argumento do uso do precedente é constituído pelos princípios da universalidade e da inércia; e (vi) o uso das formas de argumentos jurídicos especiais são hipóteses de aplicação de uma regra lógica equivalentes a outras formas do discurso prático geral.

Conclui o autor que nem no discurso prático geral e nem no discurso jurídico será possível obter uma segurança definitiva e a concreção de todas as debilidades inerentes às premissas de cada uma das espécies de discursos em questão. Todavia, esse fato por si só não é suficiente para desprezar a relevância do Direito como Ciência e nem a importância da teoria do discurso.

Além disso, reafirma Alexy que não se pode dizer que haja uma única decisão correta para cada caso, mas que o atendimento às formas e regras de fundamentação expostas pode admitir que haja a racionalidade dos resultados alcançados

${ }^{89}$ ALEXY, Robert. Teoria da Argumentação... Op. cit., p. 276.

${ }^{90}$ ALEXY, Robert. Teoria da Argumentação... Op. cit., pp. 276-278. 
na investigação, o que já é suficiente para atender a pretensão de correção. Dessa forma, a teoria do discurso tem importância precisamente porque oferece esses critérios de racionalidade à fundamentação jurídica.

\subsection{A técnica de ponderação e sua racionalidade}

E é precisamente com base nesse esquema de argumentação jurídica construído com fulcro na teoria do discurso que Alexy procura dotar de racionalidade a técnica da ponderação, a qual apresenta como alternativa mais adequada à solução dos conflitos entre princípios e a sua aplicação aos casos concretos.

Pelo exposto, resta clara a nossa simpatia pela corrente de interpretação dos direitos fundamentais por meio da ponderação, ${ }^{91}$ uma vez que entendemos ser essa técnica decorrente das próprias características de que se revestem os direitos fundamentais como princípios, entre os quais não é possível estabelecer uma hierarquia ${ }^{92}$. Vale reforçar, aqui, que é esse o principal elemento que diferencia os princípios das regras -- a forma como se soluciona o conflito entre eles.

\footnotetext{
${ }^{91}$ Alexy define da seguinte forma a lei da ponderação: "Cuanto mayor sea el grado de la no satisfacción o de afectación de uno de los principios, tanto mayor debe ser la importancia de la satisfacción del otro." ALEXY, Robert. Teoría de los Derechos... Op. cit., p. 529. E, ainda, "[o] juízo de ponderação, como entendido hoje, vincula-se à ideia de que as normas podem assumir a forma de princípios, comportando, por isso, mitigação na intensidade de sua incidência sobre caos concretos quando em conflito com outras normas, mantendo, contudo, sua validez jurídica." BRANCO, Paulo Gustavo Gonet. Juizo de... Op. cit., p. 146. Ana Paula de Barcellos, por sua vez, define a ponderação de forma geral e não apenas aplicada aos conflitos entre direitos fundamentais, vejamos: "De forma muito geral, a ponderação pode ser descrita como uma técnica de decisão própria para casos difíceis (do inglês 'hard cases'), em relação aos quais o raciocínio tradicional da subsunção não é adequado." BARCELLOS, Ana Paula de. Alguns Parâmetros Normativos para a Ponderação Constitucional. in: BARROSO, Luís Roberto (org.) A Nova Interpretação Constitucional - Ponderação, Direitos Fundamentais e Relações Privadas. Rio de Janeiro: Renovar, 2006. p. 55. Ainda sobre a ponderação e sobre uma interessante técnica de aplicação que tenta conciliá-la com juízos de subsunção, vide MORESO, José Juan. Conflictos entre Principios Constitucionales. in: CARBONELL, Miguel (org.) Neoconstitucionalismo(s). Madrid: Editorial Trotta, 2009.

92 Alexy diferencia e ao mesmo tempo identifica princípios de valores, mas afirma que a teoria dos princípios está intimamente relacionada à teoria dos valores, afirmando, contudo, ser impossível criar uma hierarquia de valores que tenha forte aplicação, a despeito de ser possível uma hierarquia fraca, aplicável a casos específicos. O autor ainda alerta para os perigos de uma "tirania dos valores", segundo a qual sempre seria necessário pagar-se o preço máximo por um valor considerado de máxima importância. ALEXY, Robert. Teoría de los...Op. cit., pp. 130-135. Uma possível forma de se hierarquizar os direitos fundamentais seria considerar, como o faz Manoel Gonçalves Ferreira Filho, que existem direitos fundamentais que são propriamente fundamentais, e outros que são apenas direitos-satélite e, portanto, devem ser considerados como garantias, de hierarquia inferior aos reais direitos fundamentais. FERREIRA FILHO, Manoel Gonçalves. Aspectos do Direito Constitucional Contemporâneo. São Paulo: Saraiva, 2009. pp. 300-303.
} 
Uma das críticas possíveis e mais feitas em relação à ponderação é a de que, na realidade, a ordem objetiva de valores em que se baseiam os juízes é uma criação pouco ou quase nada racional, o que apenas serviria para ocultar as razões subjetivas por trás de cada ponderação, de modo que esses juízos representariam meras conclusões irracionais e privadas de fundamentação real ${ }^{93}$.

Contudo, Alexy rebate essa crítica, defendendo o método da ponderação, ao assumir que ele segue todos os passos de fundamentação racional que acima detalhamos, utilizando as técnicas de justificação interna e, principalmente, as de justificação externa, cumprindo e respeitando a distribuição das cargas de argumentação, de forma a possibilitar uma solução que, se não a única correta, mais se aproxime da correção $^{94}$.

Assume ele, inicialmente, no que tange à ponderação, que se de fato esse juízo fosse um simples enunciado de preferência condicionada, ele dificilmente apresentaria qualquer racionalidade e daria margem ao subjetivismo do intérprete, de acordo com as críticas do modelo.

E é precisamente por esse motivo que o juízo de ponderação tem que vir acompanhado de um respectivo modelo de fundamentação específico que, adequado à teoria do discurso e da argumentação jurídica, se revele racional.

E para que seja possível criar esse modelo de fundamentação especificamente aplicável à ponderação, Robert Alexy menciona uma primeira regra segundo a qual quanto maior a restrição de eficácia de um princípio, maior deve ser o grau de eficácia do outro princípio que com ele conflita no caso concreto. Dessa forma, fica claro que o peso conferido a um princípio nunca é absoluto, mas depende do conflito concreto que se instaura.

\footnotetext{
${ }_{93}$ ALEXY, Robert. Teoría de los Derechos... Op. cit., p. 130.

94 "A teoria da argumentação jurídica de Alexy lança luz sobre os seus estudos em torno dos direitos fundamentais, em especial no que toca ao problema das colisões entre estes. A sua teoria da argumentação permite afirmar que o exercício da ponderação - método para aplicar normas-princípios - tem a sua racionalidade assegurada, justamente por ser uma expressão da argumentação jurídica.” BRANCO, Paulo Gustavo Gonet. Juizo de... Op. cit., p. 166.
} 
Da mesma maneira, resta evidente que, ao concretizar o raciocínio da ponderação, também o intérprete faz valorações diversas as quais, contudo, não têm o condão de comprovar a alegada irracionalidade da técnica interpretativa ${ }^{95}$, mesmo porque a valoração é um elemento intrínseco de qualquer argumentação jurídica e se dá com base em diretrizes de justificação externa diversas, todas elas aceitáveis, fundamentadas e racionais.

Ao se levar em conta todo o acima exposto, e, particularmente, a lei principal da ponderação, conclui-se que essa técnica em si jamais poderá ser considerada como um procedimento geral e abstrato, e muito menos que as suas consequências sejam prejudiciais a algum dos direitos fundamentais em conflito, já que não se obtém a eficácia de um princípio às custas de outro, mas sim preservando ao máximo o conteúdo de cada um e restringindo-os apenas até o limite em que necessário para preservar ambos os princípios no grau mais compatível com a sua importância. O que se afigura, portanto, é uma atividade de otimização ${ }^{96}$.

Desse modo, não se pode dizer que a lei de ponderação é uma lei vazia porque não estabelece uma base sobre a qual devem ser feitos os juízos de ponderação, porque ela seria uma regra vazia se não previsse nada. Entretanto, ela dispõe especificamente o que deve ser objeto de fundamentação racional.

Além disso, a ponderação pode ser responsável por criar regras e, nesse sentido, se generalizar ${ }^{97}$. Assim, aplicada a ponderação a um caso concreto, quando se repetirem os seus parâmetros em casos vindouros, já haverá uma regra criada por aquela

\footnotetext{
95 É importante deixar claro, nesse ponto, que Alexy contrapõe interpretação e ponderação, como se cada um fosse uma técnica diferente, ao passo que adotamos a ponderação apenas como uma técnica de interpretação. ALEXY, Robert. Teoría de los Derechos... Op. cit., p. 143.

${ }^{96}$ São nesse mesmo sentido as análises de BRANCO, Paulo Gustavo Gonet. Juízo de... Op. cit., pp. 167168.

97 A respeito da possibilidade de juízos de ponderação tornarem-se precedentes generalizáveis, Paulo Gustavo Gonet Branco relativiza essa possibilidade, restringindo-as às hipóteses de ponderação conceitual, de acordo com as seguintes observações que faz a respeito do direito norte-americano: "A partir de meados da década de 1970, o recurso à ponderação volta a dominar a Suprema Corte, ressurgindo em 1973, no caso Roe $v$. Wade, No julgado, procedeu-se ao que se denomina de ponderação conceptual, em que se comparam direitos em abstrato e se formula o que passa a ser uma regra, válida para casos seguintes - diferenciandose, por isso, dos casos, mais numerosos, de ponderações ad hoc, em que o resultado depende substancialmente das circunstâncias do caso concreto e não rende uma máxima de julgamento tão abrangente.” BRANCO, Paulo Gustavo Gonet. Juizo de... Op. cit., p. 93.
} 
primeira ponderação, a qual se tornará um precedente para os demais casos semelhantes ${ }^{98}$.

É importante notar que o juízo de ponderação decorre sempre de um juízo de proporcionalidade ${ }^{99}$ que se dá, como se sabe, em três fases. Nas duas primeiras delas, há um juízo de adequação e um juízo de necessidade, em que se define, respectivamente, se a medida a ser adotada atinge a finalidade que se busca e se há algum meio menos opressivo para chegar ao mesmo resultado.

A terceira fase é aquela em que haverá a ponderação propriamente dita e se denomina de proporcionalidade stricto sensu. É aqui, repita-se, que serão sopesados os valores em jogo e definida a solução com base nas vantagens e desvantagens, para ambas as partes em conflito, na adoção de um ou outro resultado ${ }^{100}$.

Nesse ponto, trata-se de aferir as possibilidades jurídicas de concretização do princípio e não mais as possibilidade fáticas -- que são objeto das análises dos outros subprincípios de adequação e necessidade. E esse juízo de proporcionalidade deve ser realizado também em três novas etapas que analisaremos abaixo ${ }^{101}$.

\footnotetext{
98 "Por medio de las ponderaciones de la jurisprudencia y las propuestas de ponderación de la ciencia de los derechos fundamentales a las que se ha prestado consentimiento, surge, con el transcurso del tempo, una red de reglas concretas adscritas a las distintas disposiciones de derecho fundamental y que representan una base importante y un objeto central de la dogmática." ALEXY, Robert. Teoría de los Derechos... Op. cit., p. 145.

99 "En el derecho constitucional alemán, se considera que la ponderación es tan sólo una parte de un principio más general. Tal principio no es otro que el de proporcionalidad (VerhaltnismaBigkeitsgrundsatz). El principio de proporcionalidad comprende tres subprincipios: adecuación, necesidad y proporcionalidad en sentido estricto. Estos tres subprincipios realizan la idea de optimización. La interpretación de los derechos fundamentales a la luz del principio de proporcionalidad implica caracterizar a los derechos fundamentales como mandatos de optimización, es decir, como principios y no simplemente como reglas." ALEXY, Robert. La Teoría del Discurso y Los Derechos Fundamentales. In.: MENÉNDEZ, Agustín José e ERIKSEN, Erik Oddvar (org.) La argumentación y los derechos fundamentales. Madrid: Centro de Estudios políticos y Constitucionales, 2010. p. 41.

100 "Ya se ha insinuado que entre la teoría de los principios y el principio de proporcionalidad existe una conexión. Esta conexión no puede ser más próxima: el carácter de principio implica el principio de proporcionalidad, y este implica aquél. Que el carácter de principio implique el principio de proporcionalidad significa que el principio de proporcionalidad, con sus tres subprincípios de idoneidad, necesidad (el mandato del medio más benigno) y de proporcionalidad en sentido estricto (el mandato de la ponderación propiamente dicho) se sigue lógicamente a partir de carácter de principio, es decir, es deducible de él." ALEXY, Robert. Teoría de los... Op. Cit., pp. 91-92. Ver, ainda, ALEXY, Robert. Constitucionalismo... Op. cit., pp. 67-68 e BRANCO, Paulo Gustavo Gonet. Juízo de... Op. cit., pp. 75 e 95 e $171-186$.

${ }^{101}$ ALEXY, Robert. Teoría de los Derechos... Op. cit., p. 529
} 
A primeira etapa de aplicação do princípio da proporcionalidade é a que apura o grau em que deixará de ser satisfeito um dos princípios em jogo -- seu peso na situação concreta. E a aferição do peso do princípio se dá mediante um juízo inicialmente abstrato, em virtude do qual se afere o valor do princípio no sistema constitucional como um todo, e posteriormente concreto, quando se perquire qual será o peso da disposição no caso analisado.

A segunda etapa é a que se volta para apurar o grau de relevância (ou o peso) do princípio em confronto que deverá prevalecer no conflito. Esse juízo deverá sempre respeitar análises fundamentadas e argumentos relevantes do ponto de vista dogmático, interpretativo e de precedentes, de forma a preservar sempre a racionalidade do discurso e permitir uma boa justificação externa.

A terceira etapa desse juízo de ponderação propriamente dito diz respeito à análise de custos e vantagens decorrentes do grau de preservação de um princípio às custas da não satisfação, ainda que parcial, do outro.

E para esse ponto, Alexy propõe uma fórmula de análise que leva em consideração as seguintes etapas de desenvolvimento. Inicialmente, seria possível estabelecer, primeiro de forma abstrata e depois no caso concreto, graus de importância de um princípio e, como resultantes, os graus de intervenção nesses mesmos princípios em conflito -- leve, médio e grave ${ }^{102}$. Assim, se tivermos o grau de relevância de um princípio como leve e o grau de intervenção como grave, fica fácil chegar ao resultado da ponderação de que deverá haver a intervenção em um direito (grau de relevância leve), deixando prevalecer o outro em maior grau (grau de intervenção grave).

Dando continuidade a esse raciocínio, Alexy anuncia o que denomina a “fórmula do peso", necessária à aferição do valor/peso de um dado princípio num caso concreto. Para ele, o cálculo do peso do "princípio 1" é possível mediante a divisão do grau de intervenção no princípio 1 pelo grau de importância do princípio que está em colisão com o princípio 1. Como essa fórmula está condicionada ao caso concreto em todas as suas variáveis, a sua formulação implica o reconhecimento de que o peso

\footnotetext{
${ }^{102}$ ALEXY, Robert. Teoría de los Derechos... Op. cit., pp. 530-546.
} 
concreto de um princípio será sempre um valor relativo -- seja em função do caso concreto, seja em função do princípio que está em confronto com ele naquela situação ${ }^{103}$.

Quando haja conflito entre princípios cujos graus de não satisfação e satisfação sejam diferentes, é fácil derivar-se das relações impostas os resultados dos princípios que deverão se sobrepor, seja por importância, seja por grau de intervenção. No entanto, quando houver empate entre esses pesos, deve-se levar em consideração que os juízos de ponderação estabelecem uma margem estrutural, que funciona da seguinte forma $^{104}$.

Ao se verificar um empate, o legislador encontra-se em uma situação em que tanto pode atuar, como pode se omitir, produzindo ambos possíveis atos -- comissivo ou omissivo -- o mesmo resultado de empate. Dessa forma, resta evidente que, nessa hipótese, o legislador encontra uma efetiva margem de atuação, por meio de seu juízo de discricionariedade, margem essa que está limitada apenas ao respeito aos direitos fundamentais, sendo ela, portanto, uma margem estrutural ${ }^{105}$.

Alexy ainda aduz, para posteriormente rechaçar, a possibilidade de esse empate ser resolvido mediante uma gradação mais refinada das classificações das intervenções e da relevância dos princípios em jogo -- ao invés de leve, médio e grave, haveria condicionantes desses três níveis, como levemente mediano, medianamente grave e assim por diante. No entanto, é evidente que, na prática, refinar os critérios das fórmulas apenas implicaria cada vez maiores dificuldades de aplicação concreta das escalas, o que tampouco resolveria todos os casos de empate, ainda que pudesse solucionar um ou outro.

Da mesma forma não funcionaria a libertação de qualquer escala de classificação da importância e da intervenção dos princípios em conflito. Isso porque o objetivo maior dessa sugestão seria suprimir os casos de empate, o que Alexy argumenta que somente seria possível em um sistema jurídico idealizado, mas jamais na realidade da interpretação jurídica diária.

\footnotetext{
${ }^{103}$ ALEXY, Robert. Teoría de los Derechos... Op. cit., pp. 539-540.

${ }^{104}$ ALEXY, Robert. Teoría de los Derechos... Op. cit., pp. 538-542.

${ }^{105}$ ALEXY, Robert. Teoría de los Derechos... Op. cit, p. 543.
} 
Demonstra-se assim, por essa ampla análise, ser totalmente racional a técnica de ponderação, desde que observados os procedimentos de justificação interna e externa das decisões judiciais nela baseadas, o que desde já é suficiente para rechaçar qualquer crítica dessa técnica com base em suposta ausência de racionalidade e conferência de discricionariedade exacerbada aos intérpretes.

\subsection{A improcedência das críticas à técnica da ponderação}

Acima demonstramos não só a racionalidade da técnica de ponderação, como também a consequente improcedência das críticas que refutam essa técnica sob o argumento de que ela não traria respostas racionais, ao passo em que conferiria ao Judiciário um amplo poder de discricionariedade para fazer valer suas próprias concepções valorativas.

Contudo, outras críticas são feitas à técnica da ponderação, as quais também entendemos improcedentes, como demonstraremos em seguida.

Paulo Gustavo Gonet Branco aponta que a aceitação da Constituição como uma ordem objetiva de valores representou, como vimos, consequente ampliação do poder do Judiciário e enfraquecimento paulatino do Legislativo e do Executivo. Todavia, no momento histórico em que surgiu a ideia dos direitos fundamentais como ordem objetiva de valores -- segundo pós-guerra -- essa consequente valorização do Judiciário e desprestígio dos demais poderes era plenamente justificável e parecia amplamente aceitável $^{106}$.

Ocorre que, consolidada essa perspectiva e transcorrido o período do segundo pós-guerra, os críticos começaram a perceber possíveis inconveniências nessa supremacia do Poder Judiciário, principalmente no tocante à interpretação da Constituição como uma ordem objetiva de valores, pois essa concepção poderia tornar os

\footnotetext{
106 “Os primeiros defensores dessa concepção dos direitos fundamentais não deixavam de perceber a consequência de aumento do poder do Judiciário daí advindo, bem assim a diminuição proporcional da força do Legislativo e do Executivo. Entendiam, contudo, que esses desdobramentos seriam inevitáveis e justificáveis, já que a experiência da confiança no legislador como garantidor dos direitos fundamentais não fora alvissareira.” BRANCO, Paulo Gustavo Gonet. Juízo de... Op. cit., p. 63.
} 
cidadãos reféns das compreensões axiológicas que os juízes teriam daqueles dispositivos de direitos fundamentais.

E nesse passo, diversas discussões acadêmicas se instauraram, especificamente no sentido de que a preponderância do Judiciário feriria o Estado Democrático de Direito na medida em que o Legislativo seria a instância democraticamente legitimada a impor significados e interpretação ao texto legal, pois ela sim estaria submetida ao crivo popular em eleições periódicas, ao passo em que seria ela também a instância desde logo legitimada pelo voto popular.

Habermas, por exemplo, critica a ponderação ao argumento de que esse método não poderia jamais resultar em juízos racionais, porque não existiria racionalidade na teoria do discurso que fundamenta a base da ideia da ponderação. Ele aponta que: (i) há diversas limitações que se impõem à atuação das partes perante o tribunal, já que elas têm interesse não na prevalência da busca cooperativa da verdade, mas na busca e prevalência de seus próprios interesses; (ii) o processo do discurso é altamente indeterminado, ainda que se estabeleçam critérios diversos para seu procedimento; e (iii) a harmonia entre direito e moral defendida por Alexy acaba por colocar sub judice a correção de uma decisão judicial ${ }^{107}$.

Além disso, Habermas qualifica de "frouxo"108 o discurso da ponderação, criticando a própria consideração dos princípios como valores, já que as normas que possuem valor elevado, condicionantes das demais normas, têm valor deontológico (o que seriam os princípios), ao passo que os valores têm cunho ontológico, o que os diferencia na essência, não permitindo a sua identificação para fins de criação de uma teoria de interpretação e aplicação de direitos fundamentais. Além disso, as normas e os valores também se diferenciariam por meio da "codificação binária gradual de sua pretensão de validade" 109 , da sua "obrigatoriedade absoluta ou relativa"

\footnotetext{
${ }^{107}$ HABERMAS, Jürgen. Direito e Democracia - entre facticidade e validade. Volume 1. Rio de Janeiro: Tempo Brasileiro, 2010. pp. 288-291.

${ }^{108}$ HABERMAS, Jürgen. Op. cit., p. 315.

${ }^{109}$ HABERMAS, Jürgen. Op. cit., p. 317.

${ }^{110}$ HABERMAS, Jürgen. Op. cit., p. 317.
} 
no que diz respeito aos critérios do "conjunto de sistemas de normas ou de valores que deve satisfazer",111.

Todavia, conforme responde o próprio Alexy, a teoria dos princípios não pressupõe que da ponderação sempre resultará uma interpretação racional, mesmo porque ela sequer admite que exista apenas uma resposta correta. Dessa forma, a teoria dos princípios e da ponderação situa-se em posição intermediária segundo a qual é possível que a ponderação leve a um juízo racional, desde que observadas as condições que já abordamos nesse capítulo. E sendo possível o resultado racional por meio da ponderação, resta desde logo superada a objeção habermasiana de que esse método seria sempre irracional $^{112}$.

Do mesmo modo, Alexy contesta a crítica de ausência de racionalidade nos juízos de ponderação referindo-se à relação sempre existente entre a ponderação e as teorias de argumentação, sendo certo que, para ele, os argumentos devidamente expressos nas decisões tornam as reflexões plausíveis e justificáveis, dotando de racionalidade os juízos de ponderação.

Portanto, resta evidente a estrutura do juízo de ponderação, derivada da própria estrutura de divisão das normas constitucionais entre princípios e regras e da distinção fundamental entre elas, consubstanciada na modalidade de solução de suas potenciais colisões.

Ocorre que o juízo de ponderação, a identificação dos direitos fundamentais como princípios, as críticas quanto à ausência de racionalidade dos juízos de ponderação já mencionadas e a consequente natural supremacia do Judiciário sobre os outros poderes decorrente da prevalência desses juízos ${ }^{113}$ acabou por transformar o perfil do Judiciário nos Estados Democráticos de Direito, criando ambientes propícios a manifestações cada vez mais participativas desse poder nos temas de eficácia e aplicabilidade dos direitos fundamentais.

${ }^{111}$ HABERMAS, Jürgen. Op. cit., p. 317.

${ }_{112}$ ALEXY, Robert. Teoria de los Derechos... Op. cit., p. 530.

${ }^{113}$ Martin Shapiro e Alec Sweet apontam os direitos fundamentais e a sua aplicação como uma de três causas para a crescente importância do Poder Judiciário e da jurisdição constitucional. SHAPIRO, Martin e SWEET, Alec Stone. On Law, politics, \& Judicialization. New York: Oxford University Press Inc., 2002, p. 153 e ss. 
E é precisamente diante desse cenário que ora descrevemos, e tendo em consideração todos os aspectos da teoria dos direitos fundamentais ora examinados desde o seu caráter histórico de desenvolvimento, até a prática de sua teoria de aplicação -, que avaliaremos como tem se dado a interpretação dos direitos fundamentais pelo Supremo Tribunal Federal, não sem antes avaliar duas possíveis consequências desse novo contexto dos direitos fundamentais na atuação do Poder Judiciário frente às normas constitucionais. 


\section{O POSICIONAMENTO DO SUPREMO TRIBUNAL FEDERAL NA PROMOÇÃO DOS DIREITOS FUNDAMENTAIS .}

\subsection{Posturas possíveis e suas justificativas}

Acima já restou demonstrado como a evolução no caráter dos princípios e na sua colocação na Constituição da República influenciaram as técnicas de interpretação constitucional e até o papel das Cortes Constitucionais nos mais diversos ordenamentos jurídicos.

Mostrou-se, também, com a análise histórica do desenvolvimento e consolidação dos direitos fundamentais, a importância social que eles vieram adquirindo com a evolução política, democrática e até tecnológica e a necessidade cada vez maior de se tornarem efetivos na prática.

Também em decorrência de todos esses aspectos, ficou muito mais clara a noção dos cidadãos da possibilidade de pleitearem perante os Tribunais competentes a efetividade dos direitos textualmente assegurados, o que contribuiu para a sua eficácia e para que os Estados transformassem em efetivas prestações positivas os direitos que haviam positivado no momento constitucional apropriado.

E é precisamente todo esse contexto que nos traz à indagação colocada no presente estudo e que se cinge a analisar, com base em apenas alguns exemplos, como tem sido feito esse trabalho de interpretação e efetiva aplicação dos direitos fundamentais pelo Supremo Tribunal Federal.

Acima já pontuamos que o caráter principiológico desses direitos fundamentais traz consequências imediatas do ponto de vista interpretativo, fazendo com que o intérprete deixe a zona de conforto constituída pelas regras precisas e passe a ter que se esforçar no sentido de ponderar valores, sopesando elementos que não podem anular um ao outro e decidindo, por uma análise subjetiva no caso concreto, quais dos princípios em jogo deve prevalecer a fim de preservar o direito fundamental que lhe pareça mais relevante naquele dado caso concreto. 
Essas matizações interpretativas, consequentemente, modificam o perfil de atuação não só do Supremo Tribunal Federal, mas do Poder Judiciário como um todo ${ }^{114}$, que vendo-se confrontado com situações em que não há regras rígidas a se aplicar, mas apenas princípios a serem ponderados, não se permite fugir da apreciação do direito posto, fazendo com que decisões diversas - e sempre sujeitas a críticas - sejam frequentemente proferidas em temas relativos à preservação e eficácia de direitos fundamentais.

Um primeiro tópico de interesse que se deve pontuar em decorrência de todo esse fenômeno é a crescente eficácia dos direitos fundamentais e até mesmo a sua popularização, diante das tentativas sempre cada vez mais numerosas de se fazer valer esses direitos perante o Poder Judiciário, mostrando que a sociedade pretende executar e colocar em prática aquelas normas previstas constitucionalmente, transformando o seu caráter que muitas vezes se limita a ser programático, em normas de eficácia plena e até mesmo imediata.

Vantagens por um lado, inconsistências por outro. Isso porque as decisões judiciais que vêm sendo tomadas acerca de direitos fundamentais, com frequência necessitam sopesar valores não só constitucionais e teóricos, como também dados práticos e de políticas públicas, o que por muitas vezes acaba por impedir a eficácia plena de um direito fundamental, ou até mesmo acaba por prejudicar a execução de uma política pública ampla, dada a necessidade de se realocar as verbas até então contingenciadas para atender a um caso específico determinado por uma decisão judicial.

Em todos esses casos, as posturas que podem ser tomadas pelo Supremo Tribunal Federal são as mais diversas e, por mais que a técnica da ponderação, já devidamente analisada na introdução do presente trabalho, seja subjacente a todas elas, é possível perceber traços que distinguem a lógica argumentativa adotada em cada caso

\footnotetext{
${ }^{114}$ No Brasil, a conformação das balizas de atuação do Poder Judiciário de forma mais elástica pode ser apontada como decorrência histórica do período autoritário vivido durante a ditadura militar, em que o Judiciário era utilizado apenas como instrumento de repressão e o Legislativo era instância submetida aos desmandos do Executivo. Nesse sentido, vide PEREIRA, Anthony W. Of Judges and Generals: Security Courts under Authoritarian Regimes in Argentina, Brazil, and Chile. In: GINSBURG, Tom e MOUSTAFA, Tamir (org.) Rule by Law - the policits of Courts in authoritarian regimes. New York, Cambridge University Press, 2008 (versão para kindle), pp. 23-57.
} 
analisado, de forma que é razoável classificar a postura do Judiciário -- e, no nosso caso específico, do Supremo Tribunal Federal -- em duas linhas distintas.

Pela primeira delas, o emprego da técnica de ponderação na análise de casos concretos que envolvam a aplicação e efetividade de direitos fundamentais descamba para o chamado ativismo judicial, hoje tão em voga no âmbito jurídicoacadêmico.

$\mathrm{Na}$ análise desse tópico específico, que será feita mais adiante, buscaremos encontrar uma definição para ativismo judicial e, de acordo com as nossas pesquisas, tentaremos diferenciar esse amplamente divulgado ativismo de um mero Judiciário ativo. Demonstraremos, como se verá adiante, que apesar de o ativismo muitas vezes parecer plenamente configurado, ele na verdade não se encontra presente, havendo tão somente a manifestação de um Judiciário ativo, dentro dos limites constitucionais.

Outra possível consequência do emprego dessa técnica de interpretação de princípios para promoção de direitos fundamentais - que foi possível observar nos casos que analisamos e que também será objeto de explanação um pouco mais detalhada em seguida - é a mutação constitucional.

E de acordo com o que será estudado nesse tópico específico, veremos que muitas das interpretações que se consideram pioneiras e até mesmo ativistas no sentido de promover alguns direitos fundamentais são, na realidade, fruto de mutações constitucionais naturais. Ao mesmo passo, buscaremos demonstrar que, em outros casos semelhantes, a mutação constitucional empreendida por meio da interpretação empregada a um princípio pode até ser considerada inconstitucional.

\subsection{O ativismo judicial}

Antes de tudo, é imprescindível definir o conceito de ativismo judicial que presidirá as análises desse trabalho ${ }^{115}$. Para tanto, adotaremos a posição do Professor

115 O ativismo, por vezes, é também considerado apenas uma forma mais assertiva ou contundente de atuação judicial, como para Frederick P. Lewis, para quem "the activism will be used in this book simply to characterize a Court willing to use its authority to engage in judicial review in an assertive manner. Such 
Elival da Silva Ramos, que define o ativismo judicial como "o exercício da função jurisdicional para além dos limites impostos pelo próprio ordenamento que incumbe, institucionalmente, ao Poder Judiciário fazer atuar, resolvendo litígios de feições subjetivas (conflitos de interesse) e controvérsias jurídicas de natureza objetiva (conflitos normativos) $" 116$.

Mas para que possamos aplicar esse conceito, é clara a necessidade de definição dos limites da função jurisdicional no ordenamento jurídico, para que seja possível identificar quando o Poder Judiciário extrapola esse limite na solução dos conflitos que lhe são apresentados.

O ativismo, portanto, pressupõe que haja liberdade de interpretação dos juízes na aplicação das regras, dos princípios e, principalmente, onde ele é mais observado, na concretização das normas constitucionais. Isso porque, sendo mais fluidas, programáticas e, na maioria das vezes, de eficácia limitada, as normas constitucionais são aquelas que dão maior espaço de interpretação aos juízes, os quais, na sua aplicação, estão mais sujeitos a incorrer no ativismo.

Conforme verificado nos capítulos precedentes, importante papel no contexto do denominado ativismo judicial possui a técnica da ponderação e a teoria dos direitos fundamentais como princípios, tendo em vista a abertura ao subjetivismo do intérprete, reconhecida pelos próprios aplicadores e filósofos dessa teoria, não obstante tenham eles desenvolvido técnicas diversas para assegurar a racionalidade dos procedimentos.

assertiveness will also imply here a considerable degree of doctrinal pronouncement that is innovative, at least in the sense that it has not been explicitly pronounced before. The term activist will be employed in opposition to describing a Court as 'restrained' in the use of its authority and in the development of doctrine." LEWIS, Frederick P. The Context of Judicial Activism - the endurance of the Warren Court legacy in a Conservative Age. Lanham: Rowman \& Littlefield Publisher Inc., 1999. p. 7.

${ }^{116}$ RAMOS, Elival da Silva. Ativismo Judicial. Parâmetros Dogmáticos. São Paulo: Saraiva, 2010. pp. 129 e 308. No mesmo sentido é o conceito de Kermit Roosevelt III: "The basic question this book sets out to answer is how we can decide whether a particular judicial decision is legitimate. The distinction between legitimate and illegitimate decisions is meant to do what the concept of activism claims to do, but fails: to distinguish between decisions that should be accepted and those that should be condemned or opposed. What I meant by a legitimate decision is essentially an appropriate exercise of judicial authority. Citizens or government officials may disagree with a legitimate decision, but it provides no basis for charging that the judges have exceeded theirs proper role." ROOSEVELT III, Kermit. The Myth of Judicial Activism making sense of Supreme Court Decisions. New Haven: Yale University Press, 2006 (versão para kindle), p. 37. 
É relevante ainda considerar que, para fins do presente trabalho, entenderemos o ativismo judicial invariavelmente como um fenômeno negativo, na esteira do que adverte Elival da Silva Ramos quando diferencia a caracterização do fenômeno nos países de common law e naqueles de civil law ${ }^{117}$. E o caráter negativo do fenômeno será consequência direta da "exacerbação no exercício da função judicante" ${ }^{\text {1118. }}$.

Tendo em vista que o ponto central para a definição do ativismo judicial reside na constatação da atuação judicial em parâmetros que extrapolem os limites da atividade jurisdicional, resta-nos imprescindível tentar definir esses limites para que possamos - mediante a análise dos casos concretos que nos propusemos a examinar perceber ou não a configuração do fenômeno na atuação do Supremo Tribunal Federal na aplicação dos direitos fundamentais.

A definição do ativismo, como acabamos de mostrar, pressupõe a exacerbação da função jurisdicional por parte do Poder Judiciário, implicando indevida incursão desse Poder nas esferas de atuação do Executivo e, ainda mais frequentemente, do Legislativo.

Ora, todos sabemos que o Estado de Direito, a duras penas conquistado, pressupõe, dentre diversos princípios fundantes, o da observância da separação dos poderes. A Constituição Brasileira, por sua vez, incorpora referido princípio em suas disposições gerais, definindo em três os Poderes da República - Executivo, Legislativo e Judiciário -, que deverão funcionar de forma independente e harmônica entre $\mathrm{si}^{119}$.

A doutrina da separação dos poderes, inaugurada propriamente por Montesquieu na sua obra "O Espírito das Leis", já sofreu diversas mitigações com o

\footnotetext{
117 “Não há, pois, necessariamente, um sentido negativo na expressão 'ativismo', com alusão a uma certa prática de jurisdição. Ao contrário, invariavelmente o ativismo é elogiado por proporcionar a adaptação do direito diante de novas exigências sociais e de novas pautas axiológicas, em contraposição ao 'passivismo', que, guiado pelo propósito de respeitar as opções do legislador ou dos precedentes passados, conduziria a estratificação dos padrões de conduta normativamente consagrados." RAMOS, Elival da Silva. Op. cit. p. 110.

${ }^{118}$ RAMOS, Elival da Silva. Op. cit. p. 129.

${ }^{119}$ É a literalidade do artigo $2^{\circ}$ da Constituição: "São Poderes da União, independentes e harmônicos entre si, o Legislativo, o Executivo e o Judiciário."
} 
desenvolvimento político das nações ${ }^{120}$ e, apesar de ser um corolário intrínseco à caracterização de um Estado de Direito, permite hoje diversas ponderações de sentido e valor que, de certa forma, justificam algumas intromissões de uns poderes em funções tradicionalmente atribuídas aos outros ${ }^{121}$.

$\mathrm{Na}$ esteira dessa necessidade de adaptar a concepção tradicional de separação de poderes, Karl Loewenstein propõe um novo modelo tripartite, sobre o qual se manifesta da seguinte maneira:

\begin{abstract}
"Es difícil desalojar un esquema mental que está profundamente enraizado, y el dogma de la separación de poderes es el más sagrado de la teoría y práctica constitucional. El iconoclasta no puede sentirse satisfecho con sólo remover de su pedestal al idolo de la triple separación del orden del dominio en los 'poderes' legislativo, ejecutivo y judicial; en su lugar estará obligado a colocar otro análisis de la dinámica del poder más de acuerdo con la soeiedad pluralista de masas de nuestro siglo. A continuación se expone una nueva división tripartita: la decisión política conformadora o fundamental (policy determination); la ejecución de la decisión (policy execution) y el controle político (policy control)."122
\end{abstract}

Na prática, essa nova conformação da teoria da separação dos poderes também é claramente perceptível. No Brasil, por exemplo, são facilmente identificados exemplos de atuação dos Poderes em funções tradicionalmente atribuídas a outros.

\footnotetext{
${ }^{120}$ Víctor Ferreres Comella aponta, inclusive, que o desenvolvimento da teoria da separação dos poderes se deu de formas diversas na Europa e nos Estados Unidos. Isso porque, enquanto na Europa a desconfiança se observava principalmente em relação ao Judiciário, nos Estados Unidos essa desconfiança era voltada ao Parlamento. Portanto, na Europa se conferiu desde logo menos possibilidades de atuação ao Judiciário, ao passo que nos EUA essa possibilidade de atuação já era aceita, ainda que não houvesse consenso sobre a sua extensão. COMELLA, Víctor Ferreres. Constitutional Courts \& Democratic Values - a european perspective. New Haven: Yale University Press, 2009. pp. 10-15. Ver também REHNQUIST, William H. The Supreme Court. New York: Vintage Books, sem indicação de ano (versão para Kindle). Posição 4557 de 4920. No mesmo sentido são os apontamentos de Stephen Powers e Stanley Rothman a respeito da desconfiança dos norte-americanos em relação aos burocratas e funcionários públicos, o que, para eles, foi um dos fatores que desencadeou o desenvolvimento de um Judiciário cada vez mais ativo naquele país. POWERS, Stephen P. E ROTHMAN, Stanley. The Least Dangerous Branch? Consequences of Judicial Activism. Westport: Praeger, 2002 (versão para kindle), posição 2920 de 3392.

${ }^{121}$ É interessante a ponderação feita pelos Professores norte-americanos Nowak e Rotunda sobre a nova conformação da separação dos poderes: "While people sometimes refer to the three branches of the federal government as a three-layer cake, it is more accurate to think of it as a marble cake. For example, Congress enacts legislation, but the President can veto it, and Congress can override the veto. The judiciary is independent, but the President appoints the judges, who must be confirmed by the Senate”. Em tradução livre: "Enquanto as pessoas muitas vezes se referem aos três ramos do governo federal como um bolo de três camadas, é mais preciso pensar a respeito como um bolo marmorizado. Por exemplo, o Congresso aprova legislação, mas o Presidente tem o poder de vetá-la e o Congresso tem novamente o Poder de descartar o veto. O Judiciário é independente, mas o Presidente nomeia os ministros, que devem ser confirmados pelo Senado." NOWAK, John E. e ROTUNDA, Ronald D. Constitutional Law. Saint Paulo: Thomson West, 2004. p. 149.

${ }^{122}$ LOEWENSTEIN, Karl. Teoria de la Constitución. Barcelona: Editora Ariel 1986. p. 62.
} 
Podemos citar, para fins de exemplificação, o exercício da função legislativa pelo Poder Executivo mediante a edição de medidas provisórias. Ainda que essas estejam submetidas e condicionadas à posterior aprovação do Congresso Nacional e à observância de requisitos de urgência e relevância, a sua edição em si já basta para criar uma norma de efeito obrigatório e nacionalmente vinculante, sendo suficiente para caracterizar o que seria uma intromissão do Executivo no Legislativo.

Apesar de altamente questionável o número elevado de medidas provisórias que têm sido editadas pelo Executivo nacional, a sua edição não configura verdadeira usurpação da função legislativa pelo Poder Executivo e não há qualquer ameaça concreta ao Estado de Direito no exercício - moderado, obviamente - dessa prerrogativa constitucionalmente assegurada.

Nesse ponto da análise, é importante frisar duas constatações. A primeira é a de que a prerrogativa de edição de medidas provisórias pelo Poder Executivo é constitucionalmente prevista e, portanto, faz parte do sistema constitucional brasileiro, o qual prevê outros mecanismos de equilíbrio entre a atuação dos poderes.

A segunda delas é a de que o exercício moderado da prerrogativa não pode ser considerado como risco nenhum ao corolário da separação dos poderes e, portanto, não representa ameaça ao Estado de Direito.

Pelo exemplo acima, pretendemos demonstrar que a possibilidade de que um dos Poderes da República exerça, em casos especiais, atividades tradicionalmente atribuídas a um dos outros poderes não pode significar de forma automática a exacerbação de suas próprias atividades e intromissão nas prerrogativas do outro Poder, porque essa espécie de atuação é constitucionalmente prevista e, desde que exercida de maneira moderada, apenas contribui para que sejam concretizados os valores assegurados pela Constituição.

Colocadas essas premissas introdutórias, passemos, então, à análise específica do ativismo judicial no contexto do ordenamento brasileiro. 
Pelo exposto, para que se caracterize o ativismo é necessário que o Poder Judiciário exacerbe a atividade jurisdicional, invadindo a esfera de funções de outros poderes, notadamente do Legislativo, ou simplesmente utilizando por base de seu posicionamento fundamentos inexistentes no ordenamento legal e constitucional.

O primeiro obstáculo na aplicação do conceito acima se encontra na necessidade de se definir o que seria a função jurisdicional, para que então se pudesse constatar quando ela fosse exacerbada. É o que tentaremos fazer em seguida.

Comecemos por observar que a Constituição brasileira, em seu artigo 102, atribuiu ao Supremo Tribunal Federal, precipuamente, a guarda da Constituição Federal $^{123}$.

Essa função de guardar a Constituição também é atribuída aos entes políticos da União, dos Estados, do Distrito Federal e dos Municípios, no artigo 23 do diploma constitucional ${ }^{124}$.

Dessa atribuição decorre, por exemplo, o poder de declarar inconstitucional uma lei aprovada pelo Congresso Nacional, em ato que poderia ser considerado como uma invasão à autonomia do Poder Legislativo, mas que é justificado sob o argumento de salvaguarda e supremacia da Carta Magna.

Daí temos que a função jurisdicional, além da tradicional atribuição de resolver os conflitos que a ela são propostos, também possui, hoje, a atribuição de definir, em abstrato, a conformidade de um ato normativo com a Constituição, podendo revogá-lo em caso de inconstitucionalidade.

Ocorre que a função de guarda da Constituição não se restringe à prerrogativa de exercer o controle de constitucionalidade. Por guarda da Constituição devemos entender também o exercício de funções que visem à preservação de seus

\footnotetext{
${ }^{123}$ Art. 102. Compete ao Supremo Tribunal Federal, precipuamente, a guarda da Constituição, cabendo-lhe: (...).

${ }^{124}$ Art. 23. É competência comum da União, dos Estados, do Distrito Federal e dos Municípios:

I - zelar pela guarda da Constituição, das leis e das instituições democráticas e conservar o patrimônio público;
} 
valores, o que pode ser feito tanto mediante a determinação de observância de seus termos pelos cidadãos e pelo Poder Público, quanto mediante a rejeição dos atos comissivos ou omissos, dos cidadãos ou do Poder Público - que estejam em desacordo com os seus termos.

Essa perspectiva, inclusive, é consequência direta da compreensão dos direitos fundamentais como conformadores de uma ordem objetiva de valores a traduzirem duas funções essenciais desses direitos: os deveres de proteção do Estado aos quais correspondem direitos subjetivos dos cidadãos a verem protegidos e realizados esses direitos - e sua eficácia irradiante.

A atividade jurisdicional, portanto, é mais do que a mera observância dos parâmetros legais previamente estabelecidos pelo legislador. Ela implica, também, a função de guarda da Constituição; ou seja, a responsabilidade não só de cumprir os valores constitucionais e fazer cumpri-los, mas também de rechaçar o seu descumprimento, tanto mediante a anulação de atos positivos de violação, quanto mediante a reforma dos atos omissivos que também impliquem transgressão.

Nesse sentido, é também importante observar que, especificamente em relação aos direitos fundamentais, a própria Constituição Federal ${ }^{125}$ é clara ao dispor que eles deverão ter aplicação imediata - ou seja, independente de qualquer regulamentação , a qual deveria ser necessariamente assegurada pelos intérpretes e guardiões da Constituição.

A análise acima deve ser ainda complementada por considerações acerca da nova hermenêutica constitucional que privilegia a força normativa dos princípios e a sua concretização.

Esse novo paradigma de interpretação, como vimos, prega, como diretriz, a conferência de especial relevância aos princípios constitucionais, como fundadores de

\footnotetext{
${ }^{125}$ Art. $5^{\circ}$ Todos são iguais perante a lei, sem distinção de qualquer natureza, garantindo-se aos brasileiros e aos estrangeiros residentes no País a inviolabilidade do direito à vida, à liberdade, à igualdade, à segurança e à propriedade, nos termos seguintes:

(...)

$\S 1^{\circ}$ - As normas definidoras dos direitos e garantias fundamentais têm aplicação imediata.
} 
uma ordem objetiva de valores, sob o argumento de preservação da própria força normativa da Constituição ${ }^{126}$.

Ao contrário do que os críticos dessas novas balizas de interpretação constitucional muitas vezes deixam transparecer ${ }^{127}$, essa nova visão dos princípios constitucionais não é um movimento exclusivamente ideológico e tem bases sólidas na própria conformação da Constituição brasileira.

Isso porque a Constituição Federal de 1988 não só optou pela regulação excessiva das matérias políticas, como também previu, por meio de seus próprios dispositivos, instrumentos aptos a conferir ao Judiciário esse poder de interpretação alargada. Desse modo, o estabelecimento de diversos princípios e de dispositivo constitucional que impõe que a sua aplicação deve ser feita de forma imediata $(\mathrm{CF}$, artigo $\left.5^{\mathrm{o}}, \S 1^{\mathrm{o}}\right)^{128}$ estimulam essa nova hermenêutica e dão margem a um papel cada vez mais expansivo do Poder Judiciário, reconformando as balizas da atividade jurisdicional, como acima demonstrado.

Ainda na esteira dessas disposições constitucionais que conferem maiores poderes ao Judiciário, a Emenda Constitucional n ${ }^{\circ}$ 45/04 atribuiu ao Supremo Tribunal Federal o poder de editar súmulas vinculantes, que deveriam ser enunciados decorrentes de reiteradas decisões da Suprema Corte, utilizados para nortear a atuação não só dos demais órgãos do Poder Judiciário, mas também dos órgãos administrativos. Referido instrumento atribuiu ao Supremo Tribunal Federal poder normativo explícito, alargando ainda mais os limites da atividade jurisdicional.

Contudo, essas novas balizas e parâmetros de atuação do Judiciário - em especial do Judiciário constitucional, no que diz respeito ao objeto do nosso trabalho são alvo de preocupações diversas, como aquelas apresentadas tanto por Elival Ramos

\footnotetext{
${ }^{126}$ DWORKIN, Ronald. Levando os Direitos... pp. 128-158.

127 ÁVILA, Humberto. Neoconstitucionalismo: entre a "ciência do direito" e o "direito da ciência". in: Vinte anos da Constituição Federal de 1988. Rio de Janeiro: Lumen Juris, 2009. p. 187 a 202.

${ }^{128}$ Exatamente nesse sentido é a análise de Manoel Gonçalves Ferreira Filho. O Papel Político do Judiciário e suas Implicações. in: Systemas, Revista de Ciências Jurídicas e Econômicas. Ano 1, n. 2. Disponível em: http://www.revistasystemas.com.br/index.php/systemas/article/view/21/16. Acesso em 27.06.2010.
} 
quanto por Humberto Ávila, esse último com foco na aplicação acrítica do neoconstitucionalismo ${ }^{129}$.

Ambos apresentam como justificativa dessa preocupação, dentre outras, a necessidade de se observarem os postulados do Estado de Direito que, segundo eles, estariam ameaçados por essa postura denominada de ativista.

Humberto Ávila dá continuidade a sua crítica com ênfase nos aspectos conformadores do neoconstitucionalismo, o qual considera como causa e consequência do ativismo judicial. Nas suas palavras, esse neoconstitucionalismo configurar-se-ia em quatro diversos aspectos: (i) normativo, segundo o qual a Constituição veicula mais princípios do que regras ${ }^{130}$; (ii) metodológico, segundo o qual o eixo de aplicação passa do método de subsunção para o de ponderação; (iii) axiológico, segundo o qual há uma inversão na aplicação da justiça, que passa a ser individual, em substituição à justiça geral $^{131}$; e (iv) organizacional, quando se verificaria, em decorrência dos três aspectos anteriores, a prevalência do Poder Judiciário sobre o Legislativo.

Nesse sentido, Humberto Ávila faz as seguintes considerações:

“(...) o Poder Judiciário não deve assumir, em qualquer matéria e em qualquer intensidade, a prevalência na determinação da solução entre conflitos morais porque, num Estado de Direito, vigente numa sociedade complexa e plural,

\footnotetext{
129 "Conviene tener presente, con todo, que cuando se habla de neoconstitucionalismo, ya sea en singular o en plural, se está haciendo referencia a dos cuestiones que deben estudiarse por separado. Por una parte, como ya se ha mencionado, a una serie de fenómenos evolutivos que han tenido evidentes impactos en lo que se ha llamado el paradigma del Estado constitucional. Por otro lado, con el término 'neoconstitucionalismo' se hace referencia también a una determinada teoría del Derecho que ha propugnado en el pasado reciente por esos cambios y/o que da cuenta de ellos, normalmente en términos bastante positivos o incluso elogioso." CARBONELL, Miguel. Prólogo: nuevos Tiempos Para El Constitucionalismo. in: CARBONELL, Miguel (org.) Op. cit., pp. 9-10.

${ }^{130}$ Alguns críticos chegam até mesmo a dizer que os juízes ativistas modificam o significado dos termos constantes da Constituição, como é a posição de Sutherland a respeito da interpretação dada pela Suprema Corte dos EUA à Primeira Emenda. Segundo ele, referido dispositivo não pode ser interpretado como a separação entre Estado e religião, como pretendem fazer crer juízes e advogados diversos, em interpretação distorcida e, na visão dele, inaceitável. "Judges are applying similar principles to laws established by the Constitution. And well-meaning people, even Christians, have the false assumption that what a judge says is law. This defies our very system of government. Our system of government gave the power of lawmaking to Congress, not the judges. And when a judge changes the definition of words within a law, he is making a new law, and that is illegal, no to mention unconstitutional." SUTHERLAND, Mark I. Redefining the Rules. In: SUTHERLAND, Mark I. (org.) Judicial Tyranny - the new kings of america? Saint louis: Amerisearch, 2007 (versão para kindle). Posição 902 de 3119.

${ }^{131}$ Nesse mesmo sentido é o alerta feito por CARRESE, Paul O. The Cloaking of Power - Montesquieu, Blackstone and the Rise of Judicial Activism. Chicago: The University of Chicago Press, 2003 (versão para kindle). pp. 258-259.
} 
deve haver regras gerais destinadas a estabilizar conflitos morais e reduzir a incerteza e a arbitrariedade decorrente da sua inexistência ou desconsideração, cabendo a sua edição ao Poder Legislativo e a sua aplicação, ao Judiciário." ${ }^{132}$

Elival Ramos, por sua vez, pontua que é

“(...) indispensável, à luz do ideário democrático, trabalhar a teoria constitucional sob as premissas de um positivismo renovado pelas conquistas da moderna Hermenêutica, situando a discricionariedade envolvida na tarefa de atuação da Constituição no plano estritamente dogmático e submetendo tanto o legislador, ao concretizar na lei comandos constitucionais, quanto o juiz, ao escolher entre diferentes possibilidades exegéticas, às exigências do Estado de Direito."

Ocorre que o Estado de Direito, por sua vez, pode ser caracterizado pela observância e respeito aos seguintes princípios: republicano, democrático, da dignidade da pessoa humana, da separação dos Poderes, do pluralismo político, da isonomia e da legalidade.

Tais críticas, contudo, parecem reduzir o primado do Estado de Direito apenas ao princípio da legalidade, conferindo a ele primazia sobre todos os demais postulados que conformam o conceito. Portanto, parecem ser extremamente frágeis diante de suas próprias premissas, mesmo porque a postura ativa do Judiciário confere primazia aos demais princípios que compõem o Estado de Direito, sem ferir o princípio da legalidade que tanto inquieta esses dois críticos.

A preocupação de ambos os autores com a preservação do princípio da separação dos poderes também se mostra nítida. Elival Ramos cita, como exemplo de intervenção indevida nesse postulado, o exercício de atividade normativa por parte do Poder Judiciário como aquela decorrente da edição de súmulas vinculantes.

Humberto Ávila, por sua vez, nem chega a mencionar o exercício do poder legiferante pelo Judiciário, restringindo-se a considerar que a possibilidade de aplicação dos princípios, por meio da ponderação, em sobreposição às regras legais aparentemente válidas, já implicaria intervenção suficientemente indevida de um poder no outro ${ }^{134}$.

132 ÁVILA, Humberto. Op. cit. pp. 26/27.

${ }^{133}$ RAMOS, Elival da Silva. Op. cit., p. 307.

${ }^{134}$ Sobre contestação às críticas de Humberto Ávila, vide SILVA, Virgílio Afonso da. Op. cit., pp. 56-64. 
Contudo, sabe-se que o princípio da separação dos poderes não significa a divisão estanque de tarefas e muito menos a impossibilidade de que um Poder exerça, ainda que de forma moderada e circunstancial, atividades de competência originária de outro Poder.

Exemplo disso, que é muito observado no Brasil e já foi por nós analisado anteriormente, é a edição de medidas provisórias pelo Poder Executivo que, nessa atuação, reveste-se de prerrogativas do Poder Legislativo.

Todavia, tanto nessa como em outras atividades, um Poder não fica imune à fiscalização dos demais, sempre atentando-se para a aplicação da teoria dos freios e contrapesos, de modo que se permita a interpenetração de referidos poderes e a interfiscalização de todas as atividades realizadas; portanto, se afigura a improcedência da crítica também no que tange a esse aspecto da realidade.

Outra crítica muito frequente atribuída ao ativismo judicial é a de que ele reduziria o espaço de atuação política da sociedade, que passaria a recorrer ao Judiciário para fazer valer as políticas que atendessem aos seus anseios, diminuindo a participação política e fragilizando, em última instância, o processo democrático ${ }^{135}$.

Nesse aspecto, diversos autores apontam que o fortalecimento da atividade judicial implicaria o declínio da tradicional mobilização política que caracteriza e define a democracia ${ }^{136}$, como desdobramento do aspecto axiológico do ativismo apontado por Humberto Ávila e acima já analisado ${ }^{137}$.

\footnotetext{
135 "The more political questions are decided by the Constitutional Court, the more political alternatives are reduced. Members of Parliament contribute to this development by giving too much consideration to legal arguments in legislation and judges contribute by sometimes exceeding their proper competencies." LANDFRIED, Christine. Germany. in: TATE, C. Neal e VALLINDER, Torbjörn (org.) The Global Expansion of Judicial Power. New York: New York University Press, 1995. p. 307. Também a esse respeito: "Populist constitutional law does not determine the outcomes of political controversies or dictate much about public. policy. Instead, it orients us as we think about and discuss where our country ought to go." TUSHNET, Mark. Taking the Constitution Away From the Courts. Princeton: Princeton University Press, 1999, p. 194.

${ }^{136}$ Não sobre a crítica, mas sobre a íntima relação entre democracia e constitucionalismo, vide BELLAMY, Richard. Policital Constitutionalism: a Republican Defence of the Constitutionality of Democracy. New York: Cambridge University Press, 2007 (versão para kindle). Vide especialmente páginas 90 e seguintes. Ver também ROBERTSON, David. The Judge as Policital Theorist. Princeton: Princeton University Press, 2010 (versão para kindle), p. 8 e ss.

${ }^{137}$ Como exemplo, podemos citar a opinião de Robert Dahl, para quem: "When the court acts within this sphere of fundamental democratic rights, the legitimacy of its actions and its place in the democratic system
} 
Nesse sentido, apontam esses estudiosos uma tendência quase global à expansão da atividade jurisdicional e até mesmo o advento de uma "juristocracia"138, com a submissão de todas as questões sociais e políticas relevantes à apreciação do Judiciário, o que retiraria do Parlamento a qualidade de instância máxima de deliberação democrática e de definição dos rumos futuros da nação ${ }^{139}$.

Contudo, essa crítica também a nosso ver é improcedente porque não se pode atribuir ao Poder Legislativo a supremacia máxima em relação aos demais poderes, inclusive em relação ao Judiciário, somente sob o argumento de que essa instância é a que detém a legitimidade popular por ter sido fruto do voto majoritário, porque também não se pode admitir a configuração de uma ditadura das maiorias; ${ }^{140}$ tendo especial relevância, nesse aspecto, o papel contramajoritário da jurisdição constitucional ${ }^{141}$.

of government can hardly be challenged. But the more it moves outside this realm - a vast realm in itself the more dubious its authority becomes. For then it becomes an unelected legislative body. In the guise of interpreting the Constitution - or, even more questionable, divining the obscure and often unknowable intentions of the Framers - the high court enacts important laws and policies that are the proper province of elected officials." DAHL, Robert. A. How Democratic is the American Constitution? New Haven: Yale University Press, 2000 (versão para kindle), posição 1209 e seguintes de 1503.

No mesmo sentido é a posição de Justice Hand, mencionada e analisada por Bickel, segundo a qual a jurisdição constitucional precisaria ser dotada de limitações graves sob pena de se criar, na realidade, uma "third legislative chamber", ou uma terceira instância legislativa. BICKEL, Alexander M. The Least Dangerous Branch - the Supreme Court at the Bar of Politics. New Haven: Yale University Press, 1962, pp. 46-49.

${ }^{138}$ Em tradução livre do termo "juristocracy" utilizado no seguinte sentido: "Over the past few years the world has witnessed an astonishingly rapid transition to what may be called juristocracy. Around the globe, in more than eighty countries in several supranational entities, constitutional reform has transferred an unprecedented amount of power from representative institutions to judiciaries. The countries that have hosted this expansion of judicial power stretch from the Eastern Bloc to Canada, from Latin America do South Africa, and from Britain to Israel. Most of these countries have a recently adopted constitution or constitutional revision that contains a bill of rights and establishes some form of active judicial review." HIRSCHL, Ran. Towards Juristocracy - the origins and consequences of the new constitutionalism. Cambridge: Harvard University Press, 2007. p. 1

139 "Por un lado, el controle en cuestión significa controlar la actividad legislativa del Parlamento, al que se considera como órgano soberano en toda forma republicana de Estado. Se critica el control del Parlamento porque hace del órgano de control un órgano funcionalmente superior al Parlamento." WRÓBLEWSKI, Jerzy. Constitución y teoria general de la interpretación jurídica. Madri: Cuadernos Civitas, 1985. P. 97. Ainda sobre a ascensão e o declínio da soberania parlamentar, vide GINSBURG, Tom. Judicial Review in New Democracies - Constitutional Courts in Asian Cases. Cambridge: Cambridge University Press, 2003 (versão para kindle), posição 43 e seguintes de 4024.

140 "De fato, a existência da maioria pressupõe, por definição, a existência de uma minoria e, por consequência, o direito da maioria pressupõe o direito à existência de uma minoria. Disto resulta não tanto a necessidade, mas principalmente a possibilidade de proteger a minoria contra a maioria Esta proteção da minoria é a função essencial dos chamados direitos fundamentais e liberdades fundamentais ou direitos do homem e do cidadão, garantidos por todas as modernas constituições das democracias parlamentaristas." KELSEN, Hans. A Democracia. São Paulo: Martins Fontes, 2000, p. 67.

141 "Costumam-se fazer certas objeções a esse sistema [de jurisdição constitucional]. A primeira, naturalmente, é que tal instituição seria incompatível com a soberania do Parlamento. Mas, à parte o fato de que não se pode falar de soberania de um órgão estatal particular, pois a soberania pertence no máximo à 
Ao nosso ver, a crítica em questão também confunde premissas e acaba por atacar aspectos que não são propriamente atribuíveis ao ativismo judicial, mas fazem parte, isso sim, da própria configuração da jurisdição constitucional e da possibilidade de realização de controle de constitucionalidade ${ }^{142}$.

Isso porque, como defendemos no presente capítulo, apenas pode ser considerado ativismo judicial aquilo que extrapolar as balizas previamente definidas pela própria Constituição como conformadoras da atuação do Poder Judiciário ${ }^{143}$. E é a própria Constituição brasileira, no caso, que prevê a possibilidade de realização de controle de constitucionalidade e de fiscalização da legitimidade dos atos do Poder Legislativo pelo Poder Judiciário, inclusive em nítida aplicação da moderna teoria da separação dos poderes, também já devidamente analisada acima.

Portanto, parece-nos que essa espécie de crítica quanto ao ativismo judicial é, primeiramente, melhor aplicável aos países em que não haja previsão específica na Constituição da prerrogativa de controle de constitucionalidade, tendo essa hipótese

própria ordem estatal, esse argumento cai por terra pelo simples fato de que é forçoso reconhecer que a Constituição regula no fim das contas o processo legislativo, exatamente da mesma maneira como as leis regulam o procedimento dos tribunais e das autoridades administrativas, que a legislação é subordinada à Constituição exatamente com o a jurisdição e a administração o são à legislação. E que, por conseguinte, o postulado da constitucionalidade das leis é, teórica e tecnicamente, absolutamente idêntico ao postulado da legalidade da jurisdição e da administração." KELSEN, Hans. Jurisdição Constitucional. São Paulo: Martins Fontes, 2007. pp. 150-151. Também analisando de forma concreta a constatação de que o sistema republicano não é por si só suficiente para preservar o direito das minorias, vide especificamente quanto ao modelo norte-americano, ELY, John Hart. Democracia e Desconfiança - uma teoria do controle judicial de constitucionalidade. São Paulo: Martins Fontes, 2010. pp. 106-115.

${ }^{142}$ No mesmo sentido, alertando para a possível confusão entre ativismo judicial e as características próprias da jurisdição constitucional, vide: "When we speak of 'judicial activism', we must be careful not to confuse it with the power of judicial review itself. The fact that the judiciary interprets the Constitution and other laws in one way or another is not in itself indicative of judicial activism at all. What the Supreme Court and the lower federal judiciary have been engaged in during the past fifty years is the systematic application of jurisdictional principles derived from the Constitution (and in many cases these derivations have been matters of intense controversy) to the reform of public institutions." POWERS, Stephen P. E ROTHMAN, Stanley. Op. cit., posição 30 de 3392.

${ }^{143}$ A esse respeito, é interessante a posição de Mark Tushnet no sentido de que, por muitas vezes, é do interesse da própria classe política delegar à Suprema Corte algumas decisões específicas, especialmente no que tange à declaração de inconstitucionalidade de leis cuja revogação poderia parecer politicamente custosa e impopular pelos próprios membros do Legislativo. TUSHNET, Mark. Why the Constitution Matters. New Haven: Yale University Press, 2010 (versão para kindle), posição 1069 e seguintes de 2135. Esse aspecto, no nosso ver, adiciona elementos à nossa resposta feita à crítica acima, na medida em que corrobora que o Legislativo faz uso político e prático da atividade da Suprema Corte, o que pode até mesmo influencia-lo quando da conformação das balizas de atuação daquele poder, permitindo que ele tenha grandes espaços de atuação. 
surgido de interpretação jurisprudencial, ainda que ampla e tradicionalmente consolidada, como é o caso dos Estados Unidos e de sua constituição enxuta e longeva.

Em segundo lugar, acreditamos que essa crítica também não deve ser dirigida ao Judiciário em si, mas ao próprio Legislativo e aos poderes constituintes que elaboraram as constituições hoje vigentes na maioria dos países. Referindo-nos especificamente ao Brasil, seria o Legislativo o destinatário da crítica porque teria sido ele a conformar as balizas de atuação do Poder Judiciário, permitindo e até determinando que ele se portasse como guardião da Constituição, realizando os controles de legitimidade necessários e protegendo a norma fundamental de maiorias inconstitucionais $^{144}$.

Vale ainda dizer que os conceitos utilizados para definir no que se constitui o ativismo não nos parecem compatíveis com as situações geralmente identificadas como ativistas. E isso se dá porque, ao nosso ver, parece haver uma nítida confusão entre Judiciário ativista e Judiciário ativo.

Quando identifica-se o ativismo judicial em alguma situação concreta sob o argumento de que, nessa situação, teria havido aplicação da técnica de ponderação e de princípios genéricos e sem regulamentação, parece-nos que a crítica não está voltada a uma atuação do Judiciário além das balizas conformadoras da atuação daquele Poder - o que propriamente caracterizaria o ativismo -, mas tão somente está voltada à postura

\footnotetext{
${ }^{144}$ Também é importante destacar aqui, a crítica de Carl Schmitt no sentido de que o Judiciário não seria a única instância dotada da atribuição de guardar, proteger e tornar eficaz a Constituição, nos seguintes termos: "Se nas constituições alemãs do século XIX está previsto um tribunal especial do Estado para a 'proteção judicial da Constituição' ao lado de outras garantias manifesta-se nelas a simples verdade de que a proteção judicial da Constituição só constitui uma parte das instituições para proteção e garantia da Constituição e que seria uma superficialidade sumária esquecer, por causa dessa proteção judicial, os limites muito estritos de toda judicância e os muitos outros tipos e métodos de uma garantia constitucional." SCHMITT, Carl. O Guardião da Constituição. Belo Horizonte: Del Rey, 2007, p. 15. Concordamos com Schmitt no ponto de que não podemos deixar de considerar as outras instâncias de guarda e proteção da Constituição, as quais inclusive nos referimos ao longo desse trabalho. Contudo, entendemos que o reconhecimento do importante papel do Judiciário não implica necessariamente o esquecimento da importância das demais instituições, mormente se a atuação judicial se der dentro das balizas conformadoras definidas pelo ordenamento jurídico. No mesmo sentido da posição de Schmitt, Mark Tushnet defende a consolidação de uma jurisdição constitucional fraca ("weak-form review") para permitir que também Executivo e Legislativo ajam como promotores dos valores constitucionais, ressaltando que uma interpretação racional dessas duas instâncias de poder deveriam ter o mesmo valor de uma interpretação racional advinda do Judiciário. TUSHNET, Mark. Weak Courts, Strong Rights - judicial review and social welfare rigts in comparative constitutional law. Princeton: Princeton University Press, 2008 (versão para Kindle). pp. 79-81.
} 
ativa e firme do Judiciário na aplicação de princípios constitucionalmente previstos, em respeito à própria função de guardião da Constituição também prevista na $\mathrm{CF}$ e em atendimento ao dispositivo que impõe que a aplicação de referidos princípios, como direitos fundamentais, seja feita de forma imediata.

Portanto, não nos parece que grande parte dessas identificações possa ser aplicada ao ambiente constitucionalmente conformado no Brasil, pois é a própria Constituição que atribui essas prerrogativas amplas e ativas ao Poder Judiciário, que agindo na aplicação de princípios, por meio da ponderação, apenas cumpre o mandamento constitucional e exerce a sua função.

O Professor Elival da Silva Ramos, por exemplo, aponta algumas situações em que entende ter havido atuação ativista por parte do STF, com as quais não concordamos integralmente.

$\mathrm{Na}$ primeira delas, ele indica o precedente em que o Supremo definiu a questão da fidelidade partidária e o mandato como sendo do partido, estipulando algumas exceções.

Para ele, no caso em questão, não obstante tenha a Corte se baseado em princípios constitucionais de representação proporcional e de monopólio das candidaturas pelos partidos, ela extrapolou os limites de sua atuação. Segundo o Professor Elival, o só fato de ter se tratado de argumentação eminentemente fundada em princípios retirou do julgado a sua legitimidade plena e o tornou um exemplo de ativismo ${ }^{145}$.

Para nós, contudo, não se tratou de hipótese de ativismo porque entendemos que a Constituição - ao descrever e elencar princípios e ao determinar que sua aplicação se dê de forma imediata - autoriza essa espécie de conduta e interpretação e até a incentiva; não havendo, no caso, atuação que transborde dos limites conferidos pelo ordenamento.

\footnotetext{
145 “Como já sucedera no âmbito dessa Justiça especializada, por se cuidar de argumentação centrada em princípios constitucionais, foram alguns dos magistrados votantes procurar apoio no moralismo jurídico e na 'principiologização' do direito, que lhe é característica, para construir a norma de decisão." RAMOS, Elival da Silva. Op. cit., p. 248.
} 
A segunda situação apontada por Elival Ramos se refere à elaboração e aprovação da Súmula Vinculante que veda o nepotismo na Administração Pública. Nesse ponto, concordamos com a afirmação do Professor ${ }^{146}$ de que houve uma postura ativista por parte do Supremo Tribunal Federal, uma vez que - não obstante a relevância da matéria e a concordância com a determinação expedida pela Corte - ela transbordou em muito as hipóteses constitucionais que autorizam a edição das súmulas, tendo atuado em total descompasso com os limites constitucionalmente fixados.

Como se percebe, o Poder Judiciário extrapola, em alguns casos concretos, esses poderes e prerrogativas já bem caracterizados acima ${ }^{147}$. Entendemos que apenas nessas hipóteses pode-se falar de Judiciário ativista, retomando-se a definição que acima adotamos, de que o ativismo judicial ocorre quando o Poder Judiciário ultrapassa as balizas de sua atuação normal e regulamentar.

Em todas as outras situações, discordando das críticas expostas e das situações concretas usualmente identificadas, entendemos que não se pode falar de ativismo judicial, mas sim meramente de um Judiciário ativo, o que é escolha, vale dizer, do próprio Poder Constituinte -- originário ou reformador -- que conformou as balizas de atuação judicial na própria Constituição de forma a conferir ao Poder ora analisado todas as prerrogativas já citadas: aplicação imediata de princípios e direitos fundamentais, o que implica, por si só, a autorização do uso da técnica da ponderação, bem como a edição de súmulas vinculantes e o controle de legalidade e constitucionalidade das leis.

Assim, definidas essas balizas, analisaremos se em algum dos exemplos selecionados de aplicação dos direitos fundamentais pode-se configurar indevido ativismo judicial, ou se apenas se verifica atuação ativa do Poder Judiciário, lembrando sempre que o nosso parâmetro de avaliação e comparação é a atuação dentro dos marcos legais e constitucionais, os quais são, por si sós, amplos.

\subsection{A mutação constitucional}

\footnotetext{
${ }^{146}$ RAMOS, Elival da Silva. Op. cit., pp. 256-264.

${ }^{147}$ Há até estudiosos que afirmam que "judicial activists are people, judges, who see truths that others so far do not." DOW, David R. America's Prophets - how judicial activism makes America great. Westport, Praeger, 2009, p. 5.
} 
Outra possível consequência da atuação do Supremo Tribunal Federal na aplicação e interpretação dos direitos fundamentais e que merece ser abordada no presente trabalho é a mutação constitucional.

A abordagem desse tema, ainda que de modo superficial, mostra-se de extrema importância uma vez que ela tem íntima relação com a interpretação e aplicação da Constituição e revela um outro lado dessa moeda que não aquele formal e teórico já demonstrado.

Por meio do exame do conceito ${ }^{148}$ e formas da mutação constitucional, poderemos entender como o Poder Judiciário, muitas vezes, pela aplicação dos princípios e normas constitucionais em geral, acaba por modificar o próprio sentido da Constituição, ainda que o seu texto permaneça o mesmo.

Não se trata aqui de atribuir um sentido a princípios de determinação vaga, mas propriamente de modificar sentidos anteriormente já atribuídos e consolidados, seja pela própria jurisprudência ou pela doutrina, ou mesmo os sentidos que inspiraram a inclusão da norma no texto constitucional.

Esses processos de mudança informal da Constituição são consequências, principalmente, de dois fatores: a concepção de Constituição rígida e suprema e as transformações sociais que, não obstante a rigidez da Constituição, devem provocar mudanças em seus sentidos a fim de que ela possa acompanhar a evolução social e, ainda assim, assegurar a sua força normativa suprema.

Konrad Hesse já estabelecia seis pressupostos dos quais dependeria a força normativa das Constituições, sendo eles: (a) coincidência entre conteúdo formal e a realidade social; (b) capacidade de adaptação da Constituição às mudanças sociais e políticas; (c) previsão de poucos princípios fundamentais que devem ter seu conteúdo aberto para definição; (d) ausência de constitucionalização de interesses momentâneos, o que pode ser obtido por um método rígido de reforma constitucional; (e) poucas

148 "Mutações constitucionais podem ser entendidas como alterações não formais na Constituição, mas que atingem o significado, alcance ou sentido do texto constitucional.” FERRAZ, Anna Cândida da Cunha. Processos Informais de Mudança da Constituição. São Paulo: Max Limonad, 1986, pp. 9, 12 e 13. 
mudanças constitucionais; e (f) conter previsões bilaterais -- a cada direito deve-se prever um dever ${ }^{149}$.

Como se vê, já se apontava a capacidade de adaptação do conteúdo formal do texto da Constituição como um pressuposto de sua força normativa, ao passo que indicava-se, como requisito necessário àquele fim, a realização de poucas mudanças textuais no diploma legal supremo.

E é exatamente nesse ponto que entra a possibilidade da mutação constitucional, para conciliar todos esses elementos e preservar a força normativa da Constituição e toda sua importância.

Karl Lowenstein, a respeito do tema, chega inclusive a mencionar que as mutações constitucionais são até mais frequentes que as reformas constitucionais, uma vez que essas últimas se dão no próprio texto e dependem de procedimentos rígidos e previamente definidos que, para preservar a rigidez e supremacia constitucionais, são sempre de difícil percurso ${ }^{150}$.

Nesse ponto, surge a ideia da Constituição como um compromisso ${ }^{151}$, já que as forças políticas que se juntam para elabora-la e aprova-la se modificam, assim como o contexto social no qual ela é realizada, de modo que a mutação constitucional aparece como importante método de preservação de sua eficácia normativa.

Essa ideia de Constituição como compromisso, ou pré-compromisso, é também adotada por Jon Elster, que aponta três formas diversas de compromisso constitucional, que coincidem parcialmente com os requisitos de preservação da eficácia normativa da Constituição apontados por Konrad Hesse: (i) diminuição do horizonte

\footnotetext{
${ }^{149}$ HESSE, Konrad. A Força Normativa da Constituição. Porto Alegre: Sergio Antonio Fabris Editor, 1991, pp. $20-21$

150 "En la mutación constitucional, por otra lado, se produce una transformación en la realidad de la configuración del poder político, de la estructura social o del equilibrio de intereses, sin que quede actualizada dicha transformación en el documento constitucional: el texto de la constitución permanece intacto. Este tipo de mutaciones constitucionales se da en todos los Estados dotados de una constitución escrita y son mucho más frecuentes que las reformas constitucionales formales. Su frecuencia e intensidad es de tal orden que el texto constitucional en vigor será dominado y cubierto por dichas mutaciones sufriendo un considerable alejamiento de la realidad, o puesto fuera de vigor." LOWENSTEIN, Karl. $O p$. cit.. p, 165.

${ }^{151}$ A esse respeito, vide TUSHNET, Mark. Op. cit.. pp. 40-42.
} 
temporal, ou seja, a busca pela estabilidade; (ii) redução de custos de transição, o que significa a minimização do parasitismo; e (iii) impedimento do advento da inconsistência agregada, ou seja, do surgimento de maiorias cíclicas ${ }^{152}$.

A própria concepção da Constituição como um pré-compromisso e, portanto, como uma forma de restrição das gerações passadas às gerações futuras, nos leva a concluir que referido compromisso somente seria válido na medida em que permanecesse condizente com os anseios populares e com a realidade social, sob pena de se comprometer a força normativa da Constituição ${ }^{153}$.

Isso significaria que o pré-compromisso assumido pelo Poder Constituinte, no momento da elaboração da Constituição, deveria ser adaptado à realidade contemporânea, por mais que alguns preceitos tivessem que ser reinterpretados à luz de novos acontecimentos e necessidades sociais, sob pena de comprometer a força normativa da Constituição.

Dessa forma, o que se conclui da própria concepção da Constituição como compromisso, ou pré-compromisso, é que, para que ela possa permanecer válida e, principalmente, eficaz, é necessário que se realizem mudanças no seu conteúdo, ainda que tais mudanças sejam informais, para fins de adaptá-la à realidade social pois, somente dessa maneira, sua força normativa estará preservada.

Também sobre esses processos de transformação informal da Constituição, é importante destacar que - conforme já foi pontuado acima quando analisamos os requisitos de Hesse e Elster para a preservação da força normativa do documento constitucional - esses processos de mudança devem estar restritos a questões efetivamente relevantes e, por essa razão, eles se dividem em momentos diferentes de

\footnotetext{
${ }^{152}$ ELSTER, Jon. Ulisses Liberto - estudos sobre racionalidade, pré-compromisso e restrições. São Paulo: Editora UNESP, 2009, pp. 151-152.

${ }^{153}$ Nesse ponto, Elster explica o que denomina de paradoxo da democracia e que assim define: "cada geração quer ser livre para restringir suas sucessoras, mas não quer sofrer restrições por parte de suas predecessoras". ELSTER, Jon. Op. cit., p. 151.
} 
mobilização social, os quais são bem explicados pela teoria de democracia dualista de Bruce Ackerman ${ }^{154}$.

Segundo esse autor, existiriam dois momentos distintos de manifestação de atividade política em uma sociedade: decisões tomadas pelo exercício de política constitucional $^{155}$ ou pelo exercício de política ordinária ${ }^{156}$.

O primeiro momento, segundo ele, seria o único a autorizar modificações substanciais na Constituição, com alteração do seu significado inicialmente definido pelo Poder Constituinte originário. Contudo, a política constitucional pressuporia efetiva mobilização popular, com debates qualificados nos fóruns especializados, o que autorizaria a dizer que suas decisões foram efetivamente tomadas pelo povo e estariam revestidas de legitimidade democrática.

Já a política ordinária consistiria no dia-a-dia da aplicação constitucional e da vivência da Constituição, consubstanciada nas decisões de governo. Nesses momentos, os cidadãos não estariam muito interessados nas questões políticas em pauta e, portanto, não havendo debates suficientes, apenas seria possível interpretar e aplicar a Constituição respeitando as diretrizes já previamente fixadas pelo Poder Constituinte originário, sem possibilidade de mutação.

Vale dizer que as mutações constitucionais - exatamente por terem que respeitar esses momentos específicos e raros de mobilização social para que possam ocorrer com respeito aos princípios democráticos - podem às vezes revelar-se inconstitucionais, ${ }^{157}$ quando por exemplo extrapolam os limites formais ou materiais fixados pelo constituinte.

\footnotetext{
${ }^{154}$ ACKERMAN, Bruce. Nós, o Povo Soberano - Fundamentos do Direito Constitucional. Belo Horizonte: Del Rey, 2006 e ACKERMAN, Bruce. Transformação do Direito Constitucional - Nós, o Povo Soberano. Belo Horizonte: Del Rey, 2008.

${ }^{155}$ Nas palavras de Ackerman: "[a]s decisões tomadas pelo povo raramente ocorrem e estão sujeitas a condições constitucionais especiais”. ACKERMAN, Bruce. Nós, O Povo Soberano - Fundamentos... Op. cit. p. 7

156 Ainda segundo Ackerman: "[a]s decisões tomadas pelo governo ocorrem diariamente; entretanto, mediante determinadas condições”. ACKERMAN, Bruce. Nós, O Povo Soberano - Fundamentos... Op. cit. p. 7

157 “As violações à Constituição assumem forma variada. Impossível registrá-las todas. Mencionem-se, portanto, algumas delas: as intepretações constitucionais legislativa, judicial e administrativa que, ao atuarem, contrariam a Constituição; as práticas ou costumes contra constitutionem - processos esses que se
} 
É importante atentar bem para a configuração de mutações inconstitucionais, pois elas não estão sujeitas a controle de constitucionalidade formal, uma vez que não estão refletidas no texto formal da Constituição, o que deve fazer com que se redobre o cuidado na sua identificação.

Ora, de tudo o quanto exposto até aqui a respeito da mutação constitucional, podemos concluir, primeiramente, que a mutação constitucional é um processo de modificação informal dos significados da Constituição de extrema relevância para a manutenção de sua força normativa.

Isso porque a Constituição, assumida como compromisso ou précompromisso, depende da mutação para que possa ajustar-se ao sempre cambiante contexto social e político, de forma a manter a sua supremacia e eficácia perante a sociedade.

Referidas modificações, contudo, devem ocorrer apenas em momentos de realização de política constitucional, ou seja, quando houver mobilização social intensa a respeito de um tema, a qual justifique que, por meio de procedimentos informais -- como a interpretação e aplicação judicial de normas -- o conteúdo da Constituição possa ser modificado de forma a não conflitar com os princípios democráticos.

E, por fim, concluímos que as mutações constitucionais devem sempre respeitar esses momentos específicos de mobilização, bem como os limites formais e materiais fixados pela Constituição, mormente porque elas não estão sujeitas a controle formal de constitucionalidade, o que pode acabar enfraquecendo a força normativa da Constituição ao invés de cumprir o seu principal objetivo de mantê-la.

Colocadas essas premissas a respeito da mutação constitucional, veremos nos casos analisados abaixo se é possível identificar essa mutação e se ela se deu de

contrapõem aos de mutação constitucional em razão das falhas apontadas. De outro lado, agrupam-se processos, violentos ou não, que podem ou não, ter, no início, base constitucional e que provocam, como resultado, mutações inconstitucionais multifárias: suspensão da Constituição, ilegitimidade do exercício do poder ou, como ultima ratio, a supressão da Constituição. Esses processos são examinados pela doutrina sob titulação variada: golpes de estado, ditaduras, revoluções." FERRAZ, Anna Candida da. Op. cit., p. 244. 
forma a respeitar o momento de política constitucional que adotamos como marco necessário a permitir essa mudança informal dos significados constitucionais.

\subsection{O processo de escolha dos casos concretos a serem analisados}

A análise do tema do nosso trabalho principia pelo exame da postura do Supremo Tribunal Federal na promoção - ou negação, a depender do ponto de vista - de direitos fundamentais mediante a decisão de casos concretos, tanto no exercício do controle difuso, quanto no exercício do controle concentrado de constitucionalidade.

Para tanto, selecionamos alguns direitos fundamentais que, segundo nossas pesquisas, tiveram maior destaque nas recentes decisões da Corte sobre o tema e que, por sua importância e pela relevância dos debates que em torno deles surgiram, são representativos da postura do Supremo em relação aos direitos fundamentais como um todo $^{158}$.

Optamos por escolher, também, julgados que nos pareceram apresentar a tendência de duração prolongada no tempo, para que os exames aqui realizados pudessem permanecer atuais por um período mais longo do que o esperado.

Principiamos, então, pela análise de julgados que abordaram o direito fundamental à dignidade da pessoa humana, à igualdade e à isonomia, ainda que de maneira transversa, os quais relatam aparentes conflitos entre esses direitos e outros de cunho fundamental e que delineiam os limites do exercício desses direitos, seus contornos, sua importância na construção do Estado Democrático de Direito e da cidadania.

O direito à dignidade da pessoa humana, por tão amplo, na realidade é aspecto invocado em todos os julgados que analisaremos, já que é feitio intrínseco de qualquer direito fundamental, mas nos casos que selecionamos para análise, ele parece obter um contorno especial.

\footnotetext{
${ }^{158}$ Vale dizer que a seleção de grupos de direitos fundamentais, ao invés de casos concretos específicos, foi uma opção considerada e decidida pela Banca no exame de qualificação que antecedeu a apresentação desse trabalho.
} 
Selecionamos, para tanto, o habeas corpus $\mathrm{HC}^{\circ} 82.424 / \mathrm{RS}^{159}$, em que o Supremo Tribunal Federal analisou a configuração do crime de racismo por meio da publicação de um livro. Apesar de não ter sido a discussão principal que permeou o julgamento, esse precedente trouxe importantes considerações acerca do princípio da liberdade de expressão e seu confronto com os princípios da dignidade da pessoa humana, da igualdade e da isonomia. E para confrontar com esse precedente, faremos a análise também do caso que entendeu constitucional o reconhecimento da união estável homoafetiva como instituto jurídico - ADPF n ${ }^{\circ} 132 / \mathrm{RJ}^{160}$.

Em seguida, analisaremos relevantes julgados que atribuíram significados distintos ao princípio da presunção de inocência, em que houve a análise de diversos princípios fundamentais e até mesmo do significado de Estado Democrático de Direito e em que também o Supremo Tribunal Federal teve que sopesar interpretações constitucionais consolidadas com os anseios populares, definindo, em uma hipótese, interpretação abrangente, e em outra, interpretação restritiva, a depender do momento histórico e político e das circunstâncias que envolveram os fatos.

Escolhemos, na espécie, a análise do habeas corpus $\mathrm{n}^{\circ} 84.078^{161}$, em que se definiu a inconstitucionalidade da execução antecipada da pena, e das ADCs n ${ }^{\circ} 29$ e 30 e ADI $4578^{162}$, que foram julgadas em conjunto, e que analisaram a constitucionalidade da chamada Lei da Ficha Limpa - Lei Complementar $n^{\circ}$ 135/10.

Em seguida, faremos o estudo da postura do Supremo Tribunal Federal frente aos direitos sociais, tomando como exemplos de análise o Agravo Regimental no Recuso Extraordinário com Agravo $\mathrm{n}^{\circ} 639.337^{163}$, em que se examinou a obrigatoriedade estatal de efetivar a matrícula de crianças em creches localizadas nas proximidades de suas residências e também o Agravo Regimental no Recurso Extraordinário $\mathrm{n}^{\mathrm{o}}$

\footnotetext{
${ }^{159} \mathrm{STF}, \mathrm{HC} \mathrm{n}^{\mathrm{o}}$ 82.242/RS, Rel. Ministro Moreira Alves, Redator para Acórdão, Min. Maurício Corrêa. Tribunal Pleno, julgado em 17.09.2003.

${ }^{160}$ STF, ADPF n ${ }^{\circ}$ 132/RJ, Rel. Min. Carlos Ayres Britto, Plenário, Julgado em 05.05.2011.

${ }^{161} \mathrm{HC}$ 84.078/MG, Rel. Min. Eros Grau, julgamento em 05-2-2009, Tribunal Pleno, DJE de 25.02.2010.

162 STF, ADC no 29, ADC $n^{\circ}$ 30, ADI 4578/DF, Rel. Min. Luiz Fux, Tribunal Pleno, julgado em 16.02.2012, DJE 29.06.2012.

${ }^{163}$ STF, AgRg no RE no 639.337/SP, Rel. Min. Celso de Mello, Segunda Turma, Julgado em 23.08.2011.
} 
271.286/RS ${ }^{164}$, em que se analisou a obrigatoriedade do Estado em fornecer gratuitamente medicamentos a pessoas destituídas de recursos financeiros.

Vale dizer que os dois julgados acima foram selecionados por serem representativos da controvérsia dos direitos sociais hoje tanto submetida ao Poder Judiciário, em diversas instâncias. Sua análise também se torna importante porque levanta o debate acerca dos limites da postura do Judiciário na análise dos direitos sociais, notadamente frente à intromissão na definição das políticas públicas e as consequências amplas de determinadas posturas.

Por fim, e como representativo da interpretação do Supremo Tribunal Federal acerca do direito à vida, analisaremos a $\mathrm{ADIN} \mathrm{n} \mathrm{n}^{0} 3.510 / \mathrm{DF}^{165}$, por meio da qual a Corte Suprema definiu a possibilidade da realização de pesquisas com células-tronco embrionárias, em um julgamento em que se colocou em destaque o aparente conflito entre valores religiosos e o progresso científico, em posicionamentos sempre permeados por considerações acerca da abrangência da dignidade da pessoa humana.

É evidente que os casos acima são apenas alguns dos inúmeros exemplos que a jurisprudência do Supremo Tribunal Federal oferece no tocante à análise e interpretação dos direitos fundamentais. Sabe-se, também, que muitos outros direitos fundamentais poderiam ter sido escolhidos como fonte de exame no presente trabalho.

Contudo, a seleção dos direitos fundamentais acima explicitados e dos julgados que escolhemos para representar a sua interpretação se deu não por uma questão de valoração de um ou de outro direito, pois consideramos que todos eles são de igual importância e devem receber a mesma atenção e concretização. A escolha se deu, em verdade, em decorrência de questões metodológicas para fins de análise crítica no presente trabalho.

Partimos, na realidade, de julgados que geraram debate público e que despertaram o interesse da sociedade, no que demonstra sua repercussão imediata na esfera da vida privada individual e seu consequente interesse direto para fins de análise

\footnotetext{
${ }^{164}$ STF, AgRg no RE no 271.286/RS, Rel. Min. Celso de Mello, Segunda Turma, Julgado em 24.11.2000.

${ }^{165}$ STF, ADI no 3510/DF, Rel. Min. Carlos Ayres Britto, Tribunal Pleno, julgado em 29.05.2008.
} 
acadêmica, mormente tendo em vista a ausência de perspectiva real de que haja alguma modificação nas interpretações conferidas em algum momento próximo.

Alguns deles, aliás, podem parecer não muito atuais, caso se leve em consideração a data de seu julgamento, mas até hoje repercutem e geram debate na sociedade, de forma que devem ser considerados como representativos de uma postura do Supremo Tribunal Federal, relevante para a análise que se pretende fazer por meio desse trabalho.

Portanto, as escolhas feitas não implicam opções de preferência ou prevalência de um direito sobre outro, ao mesmo passo em que não significam que um outro julgado, ou um outro direito se mostrem mais importantes ou tenham recebido atenções diversas do Supremo Tribunal Federal. As escolhas, com efeito, apenas se deram por razões de ordem metodológica que entendemos ficarão bem compreendidas com o raciocínio que se começará a desenvolver em seguida. 


\section{DO DIREITO FUNDAMENTAL À DIGNIDADE DA PESSOA HUMANA, À ISONOMIA E À IGUALDADE - INTERPRETAÇÃO DO SUPREMO TRIBUNAL FEDERAL ACERCA DOS INCISOS I, XLI E XLII, DO ARTIGO $5^{\circ}$ E DO INCISO III, DO ARTIGO $1^{\circ}$, TODOS DA CONSTITUIÇÃO FEDERAL}

O presente tópico revela-se bastante abrangente, uma vez que busca analisar a interpretação conferida pelo Supremo Tribunal aos postulados da isonomia, igualdade, não discriminação e dignidade da pessoa humana.

Quase todos os direitos fundamentais elencados no bojo da Constituição Federal, em última análise, levam a esses princípios básicos e basilares de qualquer Estado Democrático de Direito e pressupostos de vida digna de qualquer cidadão consciente. Por isso, por mais que pareçam tratar de matérias completamente distintas, analisaremos no presente tópico o julgamento da ADPF que decidiu sobre a constitucionalidade da união estável homoafetiva, ao passo em que examinaremos o posicionamento que a Corte adotou quando analisou conduta de racismo, definindo as suas hipóteses de configuração e incidência.

Em ambos os casos, o Supremo Tribunal Federal adotou interpretações extensivas de normas aparentemente fixas e perfeitamente estipuladas no bojo da Constituição Federal, tendo levado em consideração situações fáticas, contextos históricos e outros elementos para definir suas interpretações e conferir a máxima efetividade aos direitos fundamentais em jogo em ambos os casos.

Vejamos, primeiramente, o que restou decidido no julgamento do $\mathrm{HC} \mathrm{n}^{\mathrm{o}}$ 82.424-2/RJ, que apesar de ter ocorrido em 2003, é até hoje o acórdão paradigma do Supremo Tribunal Federal acerca do tema do racismo e que será analisado no presente tópico tendo em vista sua íntima relação com os princípios da igualdade, da isonomia, da dignidade da pessoa humana e da não-discriminação.

\subsection{Do julgamento do $\mathrm{HC} \mathrm{n}^{0}$ 82.424/RS -- a questão do racismo}


Trata-se de habeas corpus impetrado por um editor de livros acusado e condenado, em primeira e segunda instâncias, pela publicação e venda de títulos que veiculavam mensagens antissemitas, em que se considerou estar ele incurso nas penas do artigo 20 da Lei $n^{\circ} 7716 / 89^{166}$.

Condenado em segunda instância pelo crime de racismo -- considerado imprescritível --, o acusado impetrou habeas corpus perante o Superior Tribunal de Justiça buscando descaracterizar a condenação pelo racismo, a fim de que se reconhecesse a prescrição do crime que, para ele, seria meramente de discriminação.

Não tendo logrado êxito perante o STJ, impetrou novo habeas corpus perante o Supremo Tribunal Federal, em que houve ampla discussão pelo Plenário da Corte acerca dos elementos passíveis de configurar crime de racismo e dos princípios constitucionais relacionados a essa conduta que poderiam servir de norte para a decisão do caso.

Inicialmente, votou o Ministro Relator Moreira Alves, opinando pela concessão da ordem com base em argumentos que são assim passíveis de sintetização. Primeiramente, afirmou o Ministro que, de fato, o crime de racismo havia sido incluído pela Assembleia Constituinte no texto constitucional com a finalidade inicial de se preservar a raça negra das discriminações históricas havidas no país.

Para tanto, citou o Ministro os discursos proferidos pelo Deputado Constituinte que sugeriu a inclusão desse dispositivo na Constituição reforçando que a preocupação inicial dele era o combate à discriminação dos negros ${ }^{167}$ e reiterando que

\footnotetext{
166 Art. 20. Praticar, induzir ou incitar a discriminação ou preconceito de raça, cor, etnia, religião ou procedência nacional. (Redação dada pela Lei n ${ }^{\circ}$ 9.459, de 15/05/97)

Pena: reclusão de um a três anos e multa.

${ }^{167}$ Conforme mencionou em aparte feito após o voto divergente do Ministro Maurício Corrêa e em que reafirmou seu posicionamento inicial: "Para justificar juridicamente essa interpretação, em face inclusive da nossa realidade social sem qualquer conotação de atrocidade, vali-me de um critério lógico na exegese constitucional, que, nesse ponto, diferencia esta da interpretação das normas infraconstitucionais de direito público e privado. Com relação a essas normas infraconstitucionais, a partir do final do século $X I X$, quando sustentada tal posição por Josef Kohler, o que se interpreta é o que a norma diz (a mens legis) e não aquilo que, por meio dela, pretendeu dizer o legislador (a mens legislatoris), o que não é seguido na exegese de texto constitucional, que dá relevante importância ao elemento histórico do texto constitucional, e, portanto, ao que se pode extrair do que se discutiu na Assembleia Constituinte, especialmente quando entre a sua promulgação e o momento de sua aplicação não medeia longo espaço de
} 
entre a promulgação da Constituição e o momento do julgamento não havia ainda transcorrido período de tempo longo o suficiente para se considerar ter havido mudanças sociais a justificar uma interpretação evolutiva, mas que apenas se justificativa uma interpretação histórica.

Afirmou, ainda, o Relator, que a cláusula da imprescritibilidade atribuída pela Constituição ao crime de racismo era cláusula absolutamente excepcional, o que não permitia que se conferisse ao dispositivo em questão interpretação ampliada, sob pena de se atribuir significado muito extenso à norma, fugindo à sua interpretação teleológica.

Afirmou, também, com base em estudos científicos fundamentados constantes dos autos, que o judaísmo não poderia ser considerado uma raça na acepção correta do termo, o que impossibilitaria que qualquer discriminação do povo judeu viesse a ser considerada como racismo.

Assim, com base nesses argumentos principais, o Ministro Relator concedeu a ordem de habeas corpus para considerar que o crime pelo qual havia sido condenado o acusado não poderia configurar racismo e, como tal, não seria imprescritível, de forma que estava reconhecida a prescrição da pretensão punitiva no caso.

Contudo, logo em seguida, o Ministro Maurício Corrêa, após pedir vista dos autos, inaugurou a divergência com o Relator, considerando que, mesmo as manifestações antissemitas pelas quais havia sido condenado o acusado poderiam ser consideradas como racismo, sendo imprescritíveis as condutas, de forma que deveria ser negada a ordem de habeas corpus a que estava dando provimento o Relator.

O Ministro, que acabou sendo Relator para o acórdão, desenvolveu seu raciocínio também com base em laudos técnicos e estudos históricos apresentados nos autos do processo, buscando argumentar não no sentido de que os judeus seriam uma raça e que, portanto, sua discriminação configuraria crime de racismo, mas sim no sentido de

tempo a permitir a denominada interpretação evolutiva em que se leva em consideração a mudança das condições sociais." 
que não existem, na realidade, raças, sendo o ser humano uma única espécie cuja dignidade deveria ser preservada.

Segundo ele afirmou, em posicionamento que se sagrou vencedor, seria necessário não somente levar em consideração o contexto histórico de discriminação sofrido pelo povo judeu e as peculiaridades dos horrores vivenciados por esse povo, principalmente na $2^{\text {a }}$ Guerra Mundial, mas também a necessidade de se realizar uma interpretação teleológica e harmônica - e não meramente semântica - do termo "racismo" previsto no inciso XLII, do artigo $5^{\circ}$, da Constituição Federal.

Aduziu, ainda, que seria necessário realizar uma interpretação harmônica do termo em conjunto com todos os outros preceitos a ele relacionados na Constituição, possibilitando mensurar o seu real alcance por meio de análises e valorações antropológicas e sociológicas.

Para ele, a genética e seus recentes estudos foram responsáveis por banir o conceito tradicional de raça, não sendo possível o raciocínio desenvolvido pelo Relator no sentido de que a conduta do Paciente não estaria consubstanciada como racismo por ser o crime em questão o de discriminação contra o povo judeu, que sequer poderia ser considerado uma raça propriamente dita.

O Ministro Maurício Corrêa, aliás, realizou um estudo amplo do conceito de raça e da sua superação e concluiu que a interpretação a ser dada ao termo racismo constante da Constituição Federal deveria ser bem mais ampla, levando em consideração qualquer manifestação que pregasse a superioridade de um povo sobre o outro, fosse esse povo considerado ou não uma raça.

Nesse sentido, afirmou o Ministro em seu voto divergente que o que valeria na interpretação do caso concreto não seria configurar ou não a comunidade judaica como uma raça propriamente dita, mas sim de se averiguar se "quem promove o preconceito tem o discriminado com uma raça e, exatamente com base nessa concepção, promove e incita a sua segregação”. 
Como se percebe do raciocínio desenvolvido pelo Ministro Maurício Corrêa em seu voto, a interpretação conferida ao termo racismo previsto no inciso XLII, do artigo $5^{\circ}$, da Constituição Federal não se restringiu à perquirição histórica da origem e dos motivos que levaram o Constituinte a incluí-lo no texto constitucional, mas passou a uma análise mais ampla, tendo em conta outros princípios constitucionais (mencionando especificamente o artigo $3^{\circ}$, inciso IV e o artigo $4^{\circ}$, inciso VIII, da $\mathrm{CF}^{168}$ ) e circunstâncias históricas e político-sociais, realizando-se uma interpretação mais abrangente e que, ao nosso ver, pareceu mais consentânea com a finalidade de proteção dos direitos fundamentais resguardados pela norma constitucional em questão ${ }^{169}$.

Utilizou o Ministro, ainda, na fundamentação de seu voto, atos normativos internacionais sobre o tema, bem como a análise de casos semelhantes julgados por Cortes Constitucionais estrangeiras, afirmando e defendendo a universalidade e indivisibilidade dos direitos humanos e a consequente necessidade de se conferir uma interpretação única à extensão dos referidos direitos em âmbito nacional e externo.

Ressaltou ainda o Ministro que a busca pela correta acepção do termo racismo deveria levar em consideração dois aspectos fundamentais do Estado Democrático de Direito -- a dignidade da pessoa humana e a cidadania --, concluindo que qualquer interpretação harmônica com esses princípios não poderia deixar de considerar que a conduta em que incorreu o Paciente era perfeitamente enquadrável no tipo de racismo.

Também abordou-se no voto, ainda que de forma breve, a ausência de conflito entre o direito fundamental à liberdade de expressão e o direito à não discriminação. Mais uma vez recorrendo à necessidade de se realizar uma interpretação harmônica dos dispositivos constitucionais, concluiu o Ministro que não se poderia cogitar em colisão de direitos e que a ponderação jurídico-constitucional, tomando por

\footnotetext{
${ }^{168}$ Art. $3^{\circ}$ Constituem objetivos fundamentais da República Federativa do Brasil:(...)

IV - promover o bem de todos, sem preconceitos de origem, raça, sexo, cor, idade e quaisquer outras formas de discriminação.

Art. $4^{\circ}$ A República Federativa do Brasil rege-se nas suas relações internacionais pelos seguintes princípios: (...)

VIII - repúdio ao terrorismo e ao racismo;

${ }^{169}$ De acordo com o quanto foi analisado no Capítulo 2, pode-se afirmar que a interpretação conferida pelo Ministro Maurício Corrêa possuiu justificação externa mais ampla e utilizou-se de argumentos diversos mais abrangentes, sendo, portanto, melhor fundamentada e mais racional.
} 
norte o princípio da força normativa e da supremacia da Constituição, seria suficiente para resolver esse eventual conflito.

Por fim, analisando ele também os debates havidos na Assembleia Constituinte e que culminaram com a inclusão do dispositivo que previa a imprescritibilidade do racismo, afirmou que a referência aos negros decorria de natural dívida histórica da sociedade brasileira, mas que certamente não restringia a aplicabilidade do dispositivo constitucional para reparar quaisquer outras injustiças histórico culturais.

Em seguida, antecipou o seu voto o Ministro Celso de Mello, tendo acompanhado a divergência inaugurada pelo Ministro Maurício Corrêa, no sentido de se denegar a ordem pleiteada no habeas corpus.

Além de filiar-se ao entendimento exposto pelo voto que o antecedera no sentido de a própria ciência ter comprovado que o conceito tradicional de raça estava ultrapassado, o Ministro Celso de Mello focou o seu raciocínio na necessidade de preservação do princípio da dignidade da pessoa humana, como valor fundante do Estado e da ordem pública.

Utilizou-se também ele da legislação internacional, mencionando especificamente a Declaração Universal dos Direitos da Pessoa Humana, promulgada em 1948 pela $3^{\text {a }}$ Assembleia Geral da ONU e afirmando ter o Supremo Tribunal Federal o papel de preservar e de zelar pelo cumprimento e pela máxima eficácia dos direitos fundamentais assegurados naquele instrumento internacional e na Carta Magna nacional.

Além do mais, reforçou o Ministro Celso de Mello a interpendência entre democracia, direitos humanos e desenvolvimento, arguindo a necessária observância concomitante dos três valores e a circunstância de que a máxima efetividade de cada um deles apenas poderia ser obtida caso assegurada a máxima eficácia dos outros dois valores.

Em seguida, ressaltando a inexistência de direitos absolutos, afirmou que no caso em questão não se poderia cogitar da violação ao direito da liberdade de 
expressão porque a publicação pela qual era responsável o Paciente transbordava em muito do direito ao livre pensamento, passando a configurar-se mero insulto e estímulo à intolerância, não permitindo sequer a assunção de que haveria, na hipótese, algum conflito efetivo entre direitos fundamentais, figurando de um lado a liberdade de expressão e de outro o direito à igualdade e à não discriminação.

Votou em seguida o Ministro Gilmar Mendes, que houve por bem acompanhar o voto dos Ministros Maurício Corrêa e Celso de Mello. Partindo também ele de uma análise histórica sobre o antissemitismo e as suas diversas manifestações, concluiu o Ministro ser impossível evadir-se à conclusão de que também o antissemitismo poderia ser considerado uma forma de racismo, notadamente tendo em consideração as ideologias discriminatórias e seu traço fundamental de buscar convencer os demais da inferioridade da comunidade judaica, em diversos aspectos.

Em seguida, iniciou o Ministro Gilmar Mendes uma análise acerca do possível conflito entre o princípio da liberdade de expressão e o da igualdade. Para ele, a divulgação de discursos de incitação à discriminação -- aos quais se refere como "hate speech" -- é, na realidade, não decorrência do exercício da liberdade de pensamento, mas sim ameaça à própria higidez democrática, uma vez que atinge frontalmente um dos principais pilares da democracia: a igualdade.

E no presente caso, aplicando-se um juízo de ponderação por meio da incidência também do princípio da proporcionalidade -- em suas três facetas de adequação (ou proibição de excesso), necessidade e proporcionalidade stricto sensu --, resta evidente que a restrição aplicada ao princípio da liberdade de expressão encontra guarida e justificativa na eficácia do princípio da igualdade, sendo evidente que a limitação do primeiro permite que o segundo tenha efetividade, ao passo que a ausência de qualquer restrição ao primeiro anularia por completo qualquer conteúdo do segundo $^{170}$.

${ }^{170}$ Assim foi a explicação do Ministro Gilmar Mendes: "Em sintese, a aplicação do princípio da proporcionalidade se dá quando verificada restrição a determinado direito fundamental ou um conflito entre distintos principios constitucionais de modo a exigir que se estabeleça o peso relativo de cada um dos direitos por meio da aplicação das máximas que integram o mencionado princípio da proporcionalidade. São três as máximas parciais do princípio da proporcionalidade: a adequação, a necessidade e a proporcionalidade sem sentido estrito. Tal como já sustentei em estudo sobre a proporcionalidade na jurisprudência do Supremo Tribunal Federal (...), há de perquirir-se na aplicação 
Reforçou o Ministro a necessidade de se verificar a conformação da decisão atacada pelo habeas corpus com o princípio da proporcionalidade, ou seja, se a condenação do Paciente por racismo pela divulgação de livros com conteúdo antissemita de fato poderia ser qualificada como tal e considerada imprescritível.

Ressaltou que a necessidade de se averiguar a conformação da decisão em questão com o princípio da proporcionalidade decorria do fato de que a cláusula constitucional em foco -- sobre o racismo -- seria aberta, possuindo interpretações e definições que não seriam passíveis de delimitação completa pelo legislador, nascendo daí a necessidade de se verificar se a sua aplicação aos casos concretos de fato atendia aos parâmetros da proporcionalidade.

Por fim, concluiu que a decisão condenatória impugnada por meio do habeas corpus atendia ao princípio da proporcionalidade em todos os seus três desdobramentos. Ela seria adequada, tendo em vista atingir a sua finalidade de resguardar uma sociedade pluralista e tolerante. Seria, também, necessária, tendo em vista inexistir outro meio disponível para atingir a finalidade já mencionada e também seria estritamente proporcional, por restringir a liberdade de expressão apenas até o ponto necessário para se proteger o direito à igualdade e à não discriminação, preservando a eficácia desse último direito, sem negar vigência ao primeiro.

Assim, com três votos pela denegação da ordem e apenas o voto do Relator no sentido de concedê-la, iniciou seu voto o Ministro Carlos Velloso, que também acompanhou a divergência, filiando-se ao entendimento de que, no caso concreto, não haveria violação à liberdade de expressão e a manifestação analisada seria reflexo de racismo, merecendo reprimenda nos termos constitucionais, para fins de proteção ao princípio democrático e ao da dignidade da pessoa humana. Votaram em seguida os Ministros Nelson Jobim e Ellen Gracie, ambos também acompanhando as divergências.

do princípio da proporcionalidade, se em face do conflito entre dois bens constitucionais contrapostos, o ato impugnado afigura-se adequado (isto é, apto para produzir o resultado desejado), necessário (isto é,, insubstituivel por outro meio menos gravoso e igualmente eficaz) e proporcional em sentido estrito (ou seja, se estabelece uma relação ponderada entre o grau de restrição de um princípio e o grau de realização do princípio contraposto." 
Dando continuidade ao julgamento, proferiu seu voto o Ministro Cezar Peluso, que reforçou a necessidade de se realizar uma interpretação harmônica da Constituição, semelhante a uma "interpretação teleológica" e que levasse em consideração a integridade e a dignidade humanas, bem como os fundamentos próprios da República.

Finalizados esses votos, pediu vista dos autos o Ministro Ayres Britto, que, quanto ao mérito da questão, discorreu, em longo voto, sobre a configuração de um conflito entre direitos fundamentais, situando de um lado a liberdade de expressão lato sensu e, de outro, a igualdade, a democracia e o pluralismo, todos eles como frutos do direito à não discriminação e da vedação ao preconceito constantes da Constituição Federal.

Afirmou ainda o Ministro que o racismo, da forma como previsto no texto constitucional, deveria ser interpretado de maneira ampla, em todas as suas acepções históricas possíveis, uma vez que qualquer espécie de interpretação restritiva no caso concreto poderia até mesmo prejudicar a força normativa da Constituição.

Fixadas essas premissas e partindo à análise do caso concreto, o Ministro Ayres Britto acabou por considerar que o Paciente, na divulgação e elaboração das obras impugnadas e tachadas de preconceituosas e antissemitas, na realidade havia apenas construído, com pretenso rigor histórico e citação de fontes diversas, uma tese representativa de ideologia revisionista que pretendia contar a história da Segunda Guerra Mundial e de suas consequências sob a perspectiva das nações vencidas, ao invés do naturalmente divulgado ponto de vista das nações vencedoras.

Segundo o Ministro, a própria Constituição Federal assegura não ser crime a construção e manifestação de uma ideologia, inclusive em decorrência do pluralismo político -- que é um dos fundamentos da República -- e da vedação, constante do texto constitucional, à privação de convicção política ou filosófica por parte dos cidadãos.

Em sua argumentação reforçou o Ministro Ayres Britto que, na construção realizada na obra de autoria do Paciente, ele pretende distinguir o que denomina de 
Sionismo Internacional dos judeus em si, o que reforçaria apenas a construção e manifestação de uma ideologia e não a incitação ao preconceito e discriminação contra o povo judeu.

Assim, concluiu no presente caso que o uso da liberdade de expressão pelo Paciente não poderia ser considerado abusivo, tendo em vista não ter se configurado como prática preconceituosa, discriminatória ou racista, mas tão somente poderia ser considerado expressão de convicção político-ideológica, cuja liberdade é também especialmente assegurada pela Constituição Federal. Por essa razão, votou pela concessão da ordem de habeas corpus, acompanhando o Ministro Relator.

Em seguida, votou o Ministro Marco Aurélio, após pedido de vista. Referido Ministro colocou, então, como questão constitucional central a ser dirimida pelo julgamento do habeas corpus, o conflito entre dois direitos fundamentais que nomeou expressamente: a liberdade de expressão e o direito à proteção da dignidade do povo judeu. E partindo dessa premissa chegou às conclusões que abaixo expomos ${ }^{171}$.

Inicialmente, o Ministro Marco Aurélio reforçou a importância dos direitos fundamentais e de seu regime como bases propiciadoras do desenvolvimento da Democracia, ressaltando a necessidade de amplo cuidado do Supremo Tribunal Federal na análise desses princípios e direitos fundamentais, mormente quando configurado o seu conflito, como no caso sob análise.

Colocada essa premissa, o Ministro passou a analisar a importância da liberdade de expressão também na concretização dos valores democráticos e o seu papel essencial na concretização do pluralismo, do direito à crítica e da autonomia individual que, contudo, fica sobreposta pela preservação da autonomia social e da dimensão social desse direito, tendo em vista a sua capacidade de formar opiniões, de possibilitar críticas e de, dessa forma, estabilizar as instituições políticas e a democracia.

\footnotetext{
${ }^{171}$ Nesse sentido, manifestou a seguinte preocupação com a eficácia plena dos direitos fundamentais: "Dando fim a período inaceitável de ditadura militar, a Constituição de 1988 resgatou as bases do Estado Democrático de Direito, a partir da restauração concreta de um sistema de valores e princípios de direitos fundamentais que hoje constitui a verdadeira essência de uma sociedade plural e democrática. Nesse sentido, a eficácia plena dos direitos fundamentais previstos no artigo $5^{\circ}$ da Constituição, bem como de outros direitos advindos do regime e de tratados internacionais, na forma do $\$ 2^{\circ}$ desse mesmo artigo $5^{\circ}$, é condição essencial para a consolidação e amadurecimento de nossas instituições políticas e para a conservação e promoção da democracia."
} 
Em seguida, afirmou que, configurada a colisão de princípios fundamentais e surgindo a necessidade de se resolver um caso concreto mediante a técnica de ponderação, os julgadores deveriam tomar cuidado excessivo, pois a solução do caso concreto implicaria, necessariamente, limitação e restrição ao âmbito de incidência e eficácia de um ou dos dois direitos em conflito, o que exigia atenção redobrada ao caso concreto analisado, para permitir um juízo de ponderação bem fundamentado.

E mediante a análise do caso concreto, concluiu o Ministro Marco Aurélio, na esteira do quanto já havia sido afirmado pelo Ministro Ayres Britto, que a publicação de autoria do Paciente, bem como as outras por ele editadas, não poderiam ser consideradas como racistas, a despeito da necessidade de se interpretar de forma ampla o termo e de se considerar a publicação e edição de livros como meio passível de incitação de discriminação.

Afirmou o Ministro que a publicação de autoria do Paciente não continha expressões de incitação ao ódio ou à violência e nem afirmações no sentido de que o povo judeu seria inferior quando comparado a outros povos. E dessa forma, a publicação em questão apenas divulgava uma ideologia -- por mais equivocada que parecesse aos olhos de todos. E sendo apenas uma divulgação de ideologia, não poderia configurar abuso do direito de liberdade de expressão que, no caso, deveria receber máxima eficácia e proteção.

E ainda, por mais que a divulgação de uma ideologia pudesse ser considerada como um ato discriminatório e até racista em algumas hipóteses, afirmou que esse risco não estava comprovado no presente caso, tendo em vista que as publicações em questão eram antigas e tinham pouca difusão na sociedade brasileira que, além do mais, não possuía tradição histórica alguma de discriminação do povo judeu, o que reforçava a ausência de incitação ao racismo nas obras analisadas.

E adiantadas essas conclusões, o Ministro Marco Aurélio passou a realizar um juízo de ponderação acerca da colisão entre os dois princípios. E examinando o mesmo caso, sob o enfoque da mesma colisão de princípios e utilizando ainda como 
intermediador o princípio da proporcionalidade, chegou a conclusão diversa daquela haurida pelo Ministro Gilmar Mendes, ainda que realizando o mesmo raciocínio.

Para ele, a medida não seria adequada porque não teria o condão de preservar a dignidade do povo judeu. Da mesma forma, também não seria necessária, porque haveria outros meios menos gravosos aos direitos fundamentais em jogo de se preservar a dignidade daquele povo que, pelos fatos analisados, sequer havia sido atingida. Da mesma forma, então, não se revelava a pena imposta pelo Tribunal de Justiça do Rio Grande do Sul proporcional em sentido estrito, porque o fato em questão não justificava tão grave restrição à liberdade de expressão que, na realidade, implicava de fato negativa de eficácia ao princípio em jogo.

Além disso, alertou o Ministro que o Supremo Tribunal Federal, ao denegar o habeas corpus e chancelar a decisão proferida pelo Tribunal de Justiça do Rio Grande do Sul, estaria se arvorando na condição de censor de obras literárias o que implicaria, futuramente, ações para o banimento de outras obras diversas que continham passagens inegavelmente preconceituosas e discriminatórias, citando alguns conhecidos exemplos da literatura nacional e estrangeira.

Feitas essas considerações, o Ministro a afirmou que o julgamento desse habeas corpus representava "jurisprudência simbólica", no sentido de que o Tribunal adotaria uma posição de repúdio a qualquer ato antissemita quando, na verdade, o caso concreto tratava de uma análise da liberdade de expressão, a qual estava sendo relegada a último plano pela Corte ${ }^{172}$. Disse, ainda, que a postura do Supremo no caso em questão poderia se configurar também como jurisprudência-álibi, na tentativa de demonstrar à população as boas intenções do julgador no caso concreto.

\footnotetext{
${ }^{172}$ Foram essas as palavras do Ministro Marco Aurélio a esse respeito: "Pode-se, perfeitamente, trazer a teoria do simbolismo para o âmbito desta Suprema Corte. Mais especificamente, para o caso em questão. É que o Tribunal, à medida que venha a relativizar a garantia da liberdade de expressão enquadrando como manifestação racista o livro de autoria do paciente, bem como as publicações de que fora editor, terminará por praticar função simbólica, implementando uma imagem politicamente correta perante a sociedade. Estaríamos, então diante de uma hipótese de 'Jurisprudência Simbólica', sobressaindo a defesa do pensamento antinazista, quando em jogo se faz, isto sim, a liberdade de expressão, de pensamento, alfim, de opinião política. Na quadra vivida, aumenta-se o clamor social por um maior rigor penal relativamente aos fatos de grande repercussão. Assim, muitas vezes ocorre uma verdadeira inversão de valores, conduzindo à falta de proporcionalidade entre a lesão decorrente do crime e o gravame a ser suportado pelo autor. O Judiciário então surge como representante do Estado para garantir à sociedade a punição, o que foi interpretado por Kindermann, relativamente às leis, como 'confirmações de valores sociais'.,"
} 
Por fim, o Ministro analisou o significado constitucional da expressão "racismo" e defendeu que, por prever uma restrição gravíssima ao direito fundamental do devido processo legal e da prescritibilidade das condutas, a norma somente poderia ter interpretação restritiva, tendo em vista a previsão restritiva de direitos fundamentais.

E de acordo com essa interpretação restritiva necessária que deveria ser dada ao termo "racismo" e levando em conta as discussões que, na Assembleia Constituinte, levaram à inclusão do inciso XLII do artigo $5^{\circ}$ na Constituição Federal, defendeu o Ministro Marco Aurélio que racismo só poderia ser considerado como discriminação do povo negro. Assim, com base nessas razões, acompanhou o relator e o Ministro Ayres Britto para conceder a ordem de habeas corpus.

Em seguida a seu voto, o Ministro Celso de Mello pediu para confirmar o voto que havia proferido, ressaltando concordar com todos os aspectos de importância conferido pelo Ministro Marco Aurélio à liberdade de expressão, mas reafirmando ter entendido configurado o abuso a esse direito pela incitação ao ódio ao povo judeu, fator que o Ministro Marco Aurélio e os que ele acompanhou não verificaram estar configurado no caso concreto.

Por fim, o Ministro Sepúlveda Pertence acompanhou o voto divergente do Ministro Maurício Corrêa e denegou a ordem, ficando vencidos o Ministro Moreira Alves, Relator e os Ministros Ayres Britto e Marco Aurélio.

\subsection{Do julgamento sobre a união estável homoafetiva}

Ainda como bom exemplo da postura do Supremo Tribunal Federal na aplicação dos direitos fundamentais e, mais especificamente, na interpretação e eficácia do direito à dignidade da pessoa humana, vamos analisar em seguida o quanto restou decidido pela Corte Suprema no julgamento da ADPF 132/RJ, que questionou a validade das uniões estáveis homoafetivas e a sua aceitação pela Constituição Federal de 1988.

Segundo narrou em seu relatório o Ministro Ayres Britto, relator da causa, o Governo do Estado do Rio de Janeiro ajuizou a arguição de descumprimento de 
preceito fundamental em face de Decreto-Lei 220/1975, cuja interpretação vinha alijando as famílias homoafetivas dos direitos inerentes às famílias heterossexuais, em frontal violação aos direitos fundamentais da igualdade, da segurança jurídica, da liberdade e da dignidade da pessoa humana. Pediu, no mérito, a aplicação do regime jurídico da união estável às relações homoafetivas.

Ainda, por entender configurada a pertinência temática entre a ADPF 132/RJ e a ADI no 4277, ajuizada pela Procuradoria Geral da República, determinou a sua reunião e julgou-as conjuntamente. Essa ADI, como se constata, pedia ao STF que declarasse obrigatório o reconhecimento, no Brasil, da união entre pessoas do mesmo sexo como entidade familiar, aplicando-se às uniões homoafetivas, em consequência, os mesmos direitos reservados às uniões heteroafetivas. Requeria, então, em termos técnicos, que se conferisse interpretação conforme ao artigo 1.723 do Código Civil ${ }^{173}$.

Iniciando o mérito de seu voto - que é o que nos interessa no presente trabalho -, o Ministro Relator consignou que o Constitucionalismo no Brasil pode ser caracterizado como um constitucionalismo fraternal, em que se busca a integração comunitária das pessoas, como forma de concretizar o pluralismo sócio-político-cultural típico de uma democracia substancialista.

E partido desse pressuposto, invocou a norma geral negativa kelseniana (segundo a qual o que não está expressamente proibido está, consequentemente, juridicamente permitido) para afirmar que, em relação à liberdade sexual, a Constituição brasileira é silente exatamente para permitir o exercício da autonomia da vontade de forma ampla, aceitando-se qualquer manifestação de opção sexual.

Acrescentou, ainda, o Ministro Relator, que a vedação de discriminação constante do inciso IV, do artigo $3^{\circ}$ da Constituição Federal ${ }^{174}$, no que menciona a impossibilidade de discriminação pelo sexo, quer dizer a proteção do homem e da mulher

\footnotetext{
${ }^{173}$ Art. 1.723. É reconhecida como entidade familiar a união estável entre o homem e a mulher, configurada na convivência pública, continua e duradoura e estabelecida com o objetivo de constituição de família.

${ }^{174}$ Art. $3^{\circ}$ Constituem objetivos fundamentais da República Federativa do Brasil:(...)

IV - promover o bem de todos, sem preconceitos de origem, raça, sexo, cor, idade e quaisquer outras formas de discriminação.
} 
como um todo, em suas mais diversas dimensões, inclusive abarcando as preferências sexuais.

Afirmou, ainda, que a preferencia sexual é decorrência direta do princípio da dignidade da pessoa humana e consequência da autonomia da vontade, constituindose, portanto, em direito subjetivo e em liberdade concretizada no respeito à privacidade $\mathrm{e}$ à intimidade dos indivíduos. E tendo em vista a regra constitucional de autoaplicabilidade dos direitos fundamentais (artigo $5^{\circ}, \S 1^{\circ}$, da $\mathrm{CF}$ ), conjugada com a ausência de qualquer preceito constitucional divergente à interpretação que afirma $o$ direito à liberdade sexual, indiscutível seria a configuração desse direito decorrente da interpretação constitucional de todos os princípios até então citados.

E partindo dessas premissas e raciocínios, concluiu o Ministro Relator:

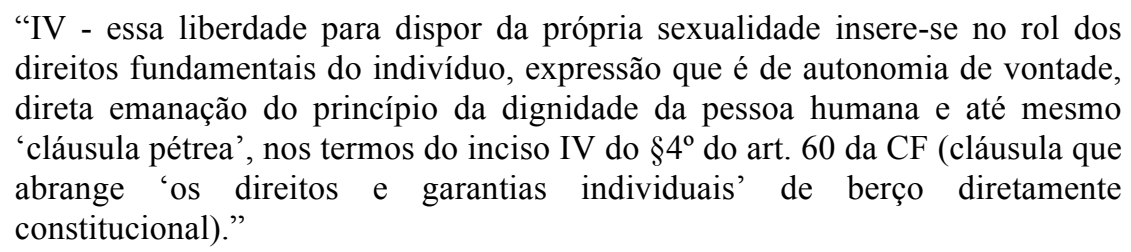

Definidas as premissas do raciocínio, o Ministro passou a analisar as disposições constitucionais a respeito da família, ressaltando a importância do caput do artigo $226^{175}$, que prevê a especial proteção estatal à família, expressão que deve ser interpretada de forma ampla, cultural e espiritual, como núcleo doméstico, sem importar se composto por um casal homo ou heteroafetivo.

E como figura central e "base da sociedade", esse conceito amplo de família deveria servir como norte para a interpretação de todos os outros conceitos dele derivados no capítulo da Constituição respectivo, como casamento civil, união estável, adoção ou planejamento familiar. Assim, a concepção abrangente de família definida pelo Ministro deveria, segundo ele, nortear a interpretação de todos os demais conceitos na Constituição Federal, e não o contrário.

${ }^{175}$ Art. 226. A família, base da sociedade, tem especial proteção do Estado. 
E analisando os demais dispositivos constitucionais que mencionam a família (especificamente os artigos 205, 227 e 230 ${ }^{176}$ ), concluiu que a Constituição não fez qualquer distinção na conceituação desse instituto, considerando como família aquela formalizada ou não, bem como aquela hetero ou homoafetiva. Afirmou, assim, que a Constituição não teria imposto à família nenhum significado ortodoxo, acolhendo referido termo apenas em seu sentido coloquial e aberto que deveria refletir as diversas formas de sua representação no seio social.

E concluiu que:

\begin{abstract}
“47. Assim, interpretando por forma não-reducionista o conceito de família, penso que este STF fará o que lhe compete: manter a Constituição na posse do seu fundamental atributo da coerência, pois o conceito contrário implicaria forçar o nosso Magno Texto a incorrer, ele mesmo, em discurso indisfarçavelmente preconceituoso ou homofóbico. Quando o certo - data vênia de opinião divergente - é extrair do sistema de comandos da Constituição os encadeados juízos que precedentemente verbalizamos, agora arrematados com a proposição de que a isonomia entre casais heteroafetivos e pares homoafetivos somente ganha plenitude de sentido se desembocar no igual direito subjetivo à formação de uma autonomizada família. Entendida esta, no âmbito das duas tipologias de sujeitos jurídicos, como um núcleo doméstico independente de qualquer outro e constituído, em regra, com as mesmas notas factuais da visibilidade, continuidade e durabilidade."
\end{abstract}

Analisando especificamente os desdobramentos normativos do artigo 226, o Ministro ainda concluiu que, quanto aos parágrafos $1^{\circ}$ e $2^{\circ}$ ("o casamento é civil e gratuita a celebração" e "o casamento religioso tem efeito civil nos termos da lei"), nada mais são o casamento civil e o religioso que formas possíveis de constituição de família, não sendo, todavia, as únicas. Ressaltou nessa análise, mais uma vez, que a Constituição de 1988 mudou o núcleo e a ênfase do "casamento" para a "família", o que necessariamente teria que ser levado em consideração pelos intérpretes.

Passou então, o Ministro, à análise do $\S 3^{\circ}$ do artigo 226 e à interpretação da "entidade familiar" ou "união estável". Referido dispositivo constitucional prevê

\footnotetext{
${ }^{176}$ Art. 205. A educação, direito de todos e dever do Estado e da família, será promovida e incentivada com a colaboração da sociedade, visando ao pleno desenvolvimento da pessoa, seu preparo para o exercício da cidadania e sua qualificação para o trabalho.

Art. 227. É dever da família, da sociedade e do Estado assegurar à criança, ao adolescente e ao jovem, com absoluta prioridade, o direito à vida, à saúde, à alimentação, à educação, ao lazer, à profissionalização, à cultura, à dignidade, ao respeito, à liberdade e à convivência familiar e comunitária, além de colocá-los a salvo de toda forma de negligência, discriminação, exploração, violência, crueldade e opressão.

Art. 230. A família, a sociedade e o Estado têm o dever de amparar as pessoas idosas, assegurando sua participação na comunidade, defendendo sua dignidade e bem-estar e garantindo-lhes o direito à vida.
} 
textualmente que "[p]ara efeito da proteção do Estado, é reconhecida a união estável entre o homem e a mulher como entidade familiar, devendo a lei facilitar sua conversão em casamento".

Para o Ministro, a intepretação do referido dispositivo, apesar da menção expressa à dualidade na formação da união estável - homem e mulher - deveria levar em consideração que a dualidade em questão decorreu de aspectos outros que nenhuma relação tinham com a distinção entre homoafetividade e heteroafetividade.

Para ele, essa dualidade prevista seria resultado, primeiramente, de uma homenagem à tradição sócio-cultural-religiosa brasileira, ao passo em que representava mais um dispositivo de reforço à isonomia entre o homem e o mulher, como tantos outros semelhantes ao longo do texto constitucional. E mais do que isso, afirmou que não se poderia interpretar de forma restrita esse dispositivo, sob pena de tornar ineficaz o caput do artigo 226. Ressaltou, ainda que a expressão "entidade familiar" não possuía sentido inferior em relação à expressão família, sendo que a Constituição não havia reservado a essa última expressão qualquer colocação restritiva que determinasse ser ela formada apenas por homem e mulher.

Assim, sendo tanto o casamento como a união estável modalidades de constituição de famílias e, não havendo na Constituição Federal qualquer restrição ou especificação das características formadoras desse núcleo familiar, não haveria razão para se impedir que as entidades familiares, ou uniões estáveis, não pudessem ser formadas por duas pessoas do mesmo sexo. Ademais, a afirmação desse direito dos casais homoafetivos não prejudica em nada qualquer direito de outrem, não havendo razão justificável para a sua restrição. ${ }^{177}$

Concluindo, então, a análise dos parágrafos do artigo 226, o Ministro referiu-se ao $\S 4^{\circ}$ e à modalidade de família monoparental protegida especificamente pela Constituição Federal. Da mesma forma, na análise do $\S 5^{\circ}$, conclui que a Constituição Federal não faz qualquer distinção entre a possibilidade de adoção de crianças por casais

\footnotetext{
${ }^{177}$ Segundo o Ministro Ayres Britto, em seu voto, “Aqui o reino é da igualdade pura e simples, pois não se pode alegar que os heteroafetivos perdem se os homoafetivos ganham."
} 
homo ou heteroafetivos ou mesmo por uma única pessoa, desde que preenchidas outras condições relevantes para o interessante da criança.

Assim, levando em consideração a proibição do preconceito e a regra do inciso II do art. $5^{\circ}$ da CF, combinado com o inciso IV, do artigo $3^{\circ}$ e o $\S 1^{\circ}$ do artigo $5^{\circ}$ também da Carta Magna, o Ministro Relator votou por dar interpretação conforme ao artigo 1.723 do Código Civil para "dele excluir qualquer significado que impeça o reconhecimento da união contínua, pública e duradoura entre pessoas do mesmo sexo como 'entidade familiar', entendida esta como sinônimo perfeito de 'família'”.

Em seguida, votou o Ministro Luiz Fux. Inicialmente, fez ele um interessante juízo acerca da pertinência temática que autorizaria a legitimidade do Governador do Rio de Janeiro para propor a medida então apreciada. Segundo ele mencionou, essa pertinência e a consequente legitimidade decorreriam dos deveres de proteção do Estado como consequência da dimensão objetiva dos direitos fundamentais. Lembrou ele que, em decorrência dessa dimensão objetiva, segundo a qual os direitos fundamentais irradiam os seus efeitos para todo o ordenamento jurídico passando a vincular as relações inclusive entre os particulares, o Estado passa a ter não só o dever de abstenção de intervenção indevida na esfera de direitos dos particulares, como também adquire o dever de proteção desses direitos nessas relações.

Assim, levando em consideração essa dimensão objetiva dos direitos fundamentais e o consequente dever de proteção do Estado em relação a esses direitos, perante os particulares, sempre na tentativa de promover a sua máxima eficácia, deve-se reconhecer a pertinência temática e a legitimidade do Governador de Estado-membro de provocar a jurisdição constitucional para concretizar o seu dever de proteção e buscar a máxima eficácia dos direitos fundamentais de seus cidadãos.

Superadas as questões preliminares, fixou o Ministro Luiz Fux cinco premissas que norteariam o seu raciocínio futuro, a saber: (i) a homossexualidade é um fato da vida; (ii) a homossexualidade é uma orientação e não uma opção; (iii) a homossexualidade não é uma ideologia ou uma crença; (iv) os homossexuais constituem relações contínuas, duradouras e de afeto e assistência recíprocos; e (v) não há qualquer 
inconstitucionalidade ou ilegalidade no estabelecimento de uniões homoafetivas, as quais não são vedadas pelo direito brasileiro.

Fixadas essas premissas, afirmou o Ministro que o Supremo Tribunal Federal, no presente caso, deveria agir como instância contramajoritária para assegurar o usufruto dos direitos fundamentais pela minoria homossexual. Afirmou, ainda, no que poderia ser considerado um argumento de extrapolação dos limites da atividade jurisdicional e invasão da competência legislativa, que "o ato de constituição da união homoafetiva existe, ocorre e gera efeitos juridicamente relevantes, que, portanto, merecem tratamento pelo direito".

Em seguida, filiando-se ao ponto central do raciocínio desenvolvido pelo Ministro Relator, o Ministro Luiz Fux partiu do pressuposto de família como "base da sociedade" e como instituição merecedora de proteção especial por parte do Estado, bem como da evolução da proteção constitucional, que passou do privilégio à instituição do casamento para o foco central na instituição da família, para concluir no mesmo sentido do voto proferido anteriormente.

Para ele, a família deveria ser considerada como um ambiente de realização, fomento e desenvolvimento dos direitos fundamentais, de forma que nenhuma interpretação que implicasse restrição ou negativa de eficácia a qualquer um desses direitos fundamentais poderia servir para atribuir o conceito correto do termo "família"178.

Em decorrência disso, e levando em consideração que a família é distinguida e definida por três aspectos em comum: (i) amor familiar; (ii) identidade; e (iii) comunhão, concluiu o Ministro que, sob pena de se ferir de morte o princípio da isonomia, não se pode apontar qualquer diferenciação ontológica entre uniões estáveis homoafetivas e heteroafetivas.

Ademais, também na mesma esteira do raciocínio desenvolvido pelo Ministro Relator, argumentou em seu voto que "inexistindo razão suficiente para o

\footnotetext{
${ }^{178}$ Para o Ministro Luiz Fux, "não pode haver compreensão constitucionalmente adequada do conceito de família que aceite o amesquinhamento de direitos fundamentais”.
} 
tratamento jurídico diferenciado, impõe-se o tratamento jurídico idêntico", de forma que todos os indivíduos devem ser tratados com o mesmo respeito, sob pena de se configurar preconceito e intolerância expressamente vedados por dispositivos constitucionais localizados no seu preâmbulo, no inciso IV do artigo $3^{\circ}$ e no caput do artigo $5^{\circ}$.

E não apenas mencionou o Ministro a violação ao princípio da isonomia e da igualdade, mas reforçou também ocorrer violência ao princípio da dignidade da pessoa humana, na sua faceta da autonomia da vontade, em virtude do silêncio do legislador a respeito da união homoafetiva, em total desrespeito à dignidade das minorias homossexuais e ao seu direito da personalidade.

Aí é que o Ministro Luiz Fux apresenta um raciocínio adicional àquele desenvolvido pelo Ministro Relator, quando argumenta que, no caso do direito dos homossexuais no Brasil, não se pode entender que a mera pregação de política de igualdade e respeito, com base na inexistência de vedação legal à sua união seja suficiente para promover a igualdade material.

Isso porque o silêncio legislativo, nessa hipótese, não significa tolerância, na prática, mas sim rejeição. Isso implica, consequentemente, a necessidade de se realizarem o que ele denomina de "políticas de reconhecimento", inclusive para promover segurança jurídica nesse aspecto.

Assim, fazendo referência à força normativa da Constituição e da necessidade de adequar sempre a sua interpretação às mudanças sociais havidas no seio da sociedade, concluiu o Ministro Luiz Fux que deveria ser dada interpretação conforme ao artigo 1.723 do Código Civil, esclarecendo que a aparente restrição nele contida quando prevê a união entre homem e mulher - tinha objetivo integrador e, portanto, não pode ser agora interpretada como vedação à plena concretização dos direitos fundamentais dos casais homoafetivos.

Votou em seguida, então, a Ministra Cármen Lúcia, também acompanhando o voto do Ministro Relator. Reforçou a Ministra em seu voto que a função do Tribunal e a do direito constitucional era precisamente defender e garantir os direitos fundamentais, devendo repudiar qualquer forma de preconceito. 
Ressaltou que a Constituição, como um sistema que é, deve ser interpretada de forma harmônica com todo o seu conjunto de princípios. E, dessa forma, a norma do $\S 3^{\circ}$ do artigo 226 da Constituição não poderia receber qualquer interpretação que implicasse a diferenciação injustificada de tratamento entre os casais homoafetivos e os heteroafetivos, mormente tendo em vista os postulados da liberdade, da dignidade da pessoa humana, da igualdade, do pluralismo social, da intimidade e da vedação ao preconceito.

Logo após proferiu seu voto o Ministro Ricardo Lewandowski, também acompanhando os Ministros que o antecederam e acrescentando, na fundamentação, alguns pontos que detalharemos em seguida.

Invocou ele, inicialmente, discussões havidas na Assembleia Constituinte para defender que a previsão do $\S 3^{\circ}$, mormente na parte em que restringia a união estável à relação entre homem e mulher, queria deixar clara a possibilidade única desse instituto se configurar nas relações heterossexuais ${ }^{179}$.

Além disso, mencionou que a Constituição erigiu à condição de cláusula pétrea a garantia da "separação dos poderes" de modo que a atuação do Judiciário, por mais criativa que pudesse ser, deveria observar os limites objetivos da norma, os quais estavam bem definidos pelo texto e pelo contexto que culminaram com a redação do $\S 3^{\circ}$ do artigo 226.

Sendo assim, segundo o Ministro Lewandowski, para se permitir a união estável homoafetiva, teria que se considerar a existência de uma outra espécie de entidade familiar não prevista originalmente no texto do artigo 226 e em seus parágrafos. E essa nova entidade familiar poderia ser deduzida de uma leitura sistemática do texto constitucional, levando em conta os princípios da dignidade da pessoa humana, da igualdade, da liberdade, da preservação da intimidade e da não-discriminação.

${ }^{179}$ E como consequência dessa afirmação, vaticinou o Ministro Lewandowski: "Não há, aqui, penso eu, com o devido espeito pelas opiniões divergentes, como cogitar-se de uma de mutação constitucional ou mesmo de proceder-se a uma interpretação extensiva do dispositivo em foco, diante dos limites formais e materiais que a própria Lei Maior estabelece no tocante a tais procedimentos, a começar pelo que se contém no art. 60, $\$ 4^{\circ}$, III, o qual erige a 'separação dos Poderes' à dignidade de 'cláusula pétrea', que sequer pode ser alterada por meio de emenda constitucional". 
E assumindo que a união estável homoafetiva seria uma quarta modalidade de entidade familiar decorrente apenas de interpretação sistemática e harmônica da Constituição e não de interpretação conforme de dispositivos já previstos constitucional e legalmente, o Ministro teve que lançar mão da integração analógica para, na falta de normatização legislativa, definir os critérios para configuração desse novo gênero familiar ainda não positivado ${ }^{180}$.

Vale fazer uma observação pessoal nesse ponto da análise dos votos. Curiosamente, o Ministro Lewandowski invocou o princípio da separação dos poderes para justificar a impossibilidade de modificar o sentido que pretendia a Assembleia Constituinte conferir ao $\S 3^{\circ}$ do artigo 226. Ora, a adoção da interpretação conforme daquele dispositivo significaria apenas integração interpretativa. Todavia, preferiu o Ministro, em atitude que nos parece afrontar muito mais o princípio por ele invocado da separação de poderes, criar interpretativamente uma nova norma, lançando mão da técnica de integração analógica para definir os seus parâmetros, assumindo fazê-lo em decorrência da ausência de regramento legal específico.

Independentemente dessa aparente contradição, o Ministro concluiu que o rol de entidades familiares previsto no artigo 226 da Constituição Federal é meramente exemplificativo e, não obstante o $\S 3^{\circ}$ previsse apenas a união estável entre homem e mulher, não haveria qualquer impedimento legal ou constitucional para a $o$ reconhecimento também de uniões estáveis públicas, contínuas e duradouras homoafetivas, o que deveria ser feito pelo método de integração analógica a suprir uma lacuna normativa até manifestação legislativa específica sobre a matéria.

Tendo votado o Ministro Ricardo Lewandowski que, apesar de acompanhar os demais Ministros no resultado, divergiu amplamente na fundamentação, foi a vez de se pronunciar o Ministro Joaquim Barbosa.

\footnotetext{
${ }^{180}$ A esse respeito, esclareceu o Ministro Lewandowski: "Como se sabe, ante a ausência de regramento legal específico, pode o intérprete empregar a técnica da integração, mediante o emprego da analogia, com o fim de colmatar as lacunas porventura existentes no ordenamento legal, aplicando, no que couber, a disciplina normativa mais próxima à espécie que lhe cabe examinar, mesmo porque o Direito, como é curial, não convive com a anomia”.
} 
Para ele, o descompasso existente entre o mundo dos fatos e o universo do direito, muito bem representado pela controvérsia sob análise, deveria ser solucionado pela Corte Constitucional, sendo um de seus fundamentais papeis exatamente a criação de pontes entre a realidade fática e a ordem jurídica. Reforçou, ainda, que na sua concepção o constituinte não havia pretendido excluir o direito dos casais homoafetivos com a previsão do $\S^{\circ}$ do artigo 226.

Todavia, concluiu que, não por interpretação desse $\S 3^{\circ}$, mas pela análise integrativa dos princípios da dignidade da pessoa humana, da igualdade e da nãodiscriminação, deveria ser considerada constitucional a união estável homoafetiva.

Votou em seguida o Ministro Gilmar Mendes que, destacando que inicialmente havia manifestado preocupação com a forma como exposto o pedido nas ações - interpretação conforme de dispositivo legal que apenas reproduzia literalmente dispositivo constitucional -, pontuou que, tendo constatado, contudo, que o dispositivo legal em comento servia como fundamento para decisões que negavam a pretensão de ver reconhecida a união estável homoafetiva, acompanhava o entendimento dos demais colegas no sentido de conferir a interpretação conforme de acordo com o quanto formulado nos pedidos iniciais.

Fez uma pequena digressão inicial sobre os limites da interpretação conforme e de outras técnicas interpretativas da jurisdição constitucional para concluir que o Supremo Tribunal Federal, na esteira de outras Cortes Constitucionais do Direito Comparado, estava aos poucos se livrando da tradicional postura de legislador negativo para adotar cada vez mais decisões interpretativas com eficácia aditiva ${ }^{181}$, como poderia vir a ser o caso da decisão tomada no presente julgamento.

O Ministro ainda fez importante observação quanto ao papel do Supremo Tribunal Federal e as frequentes críticas que recebe de setores da sociedade por encampar

\footnotetext{
${ }^{181}$ Como exemplos de decisões manipulativas de efeitos aditivos, o Ministro Gilmar Mendes citou o Mandado de Injunção que decidiu sobre o direito de greve dos servidores públicos (MI $\left.n^{\circ} 670\right)$, a questão da demarcação da terras indígenas na reserva Raposa Serra do Sol (Pet 3388/RR), RE em que se discutiu isonomia de isenção tributária (RE 405.579) e a possibilidade de vir a ocorrer o mesmo no julgamento da ADPF 54, que julgaria a questão do aborto dos fetos anencéfalos.
} 
decisões que podem ser consideradas - inadequadamente, segundo externou o Ministro como atos privativos do legislador positivo.

Aliás, a esse respeito, manifestou-se da seguinte forma o Ministro Gilmar

Mendes:

\begin{abstract}
"É. Não há nenhuma dúvida de que aqui o Tribunal está assumindo um papel, ainda que, provisoriamente, pode ser que o legislador venha a atuar, mas é inequívoco que o Tribunal está dando uma resposta de caráter positivo. Na verdade, essa afirmação - eu já tive oportunidade de destacar - tem de ser realmente relativizada diante de prestações que envolvem a produção de norma ou a produção de um mecanismo de proteção; tem de haver aí uma resposta de caráter positivo. E se o sistema, de alguma forma, falha na composição desta resposta e se o Judiciário é chamado, de alguma forma, a substituir ao próprio sistema político, óbvio que a resposta só poderá ser esta de caráter positivo. $\mathrm{Na}$ verdade, essa própria afirmação já envolve um certo engodo metodológico. Eu dizia que até a fórmula puramente cassatória, quando se cassa uma norma por afirma-la inconstitucional - na linha tradicional de Kelsen -, essa própria fórmula já envolve também uma legislação positiva no sentido de se manter um status quo contrário à posição que estava a ser...”
\end{abstract}

Argumentou ainda o Ministro Gilmar Mendes que, de fato, o ideal seria que o Legislativo fornecesse uma resposta à questão socialmente colocada. Contudo, o sistema representativo, nesse caso, apresentava uma inércia natural da aprovação popular e, a despeito de inúmeros projetos sobre a matéria, o Congresso Nacional não deliberava definitivamente sobre a matéria.

Assim, tendo em vista a inércia legislativa e, ainda, o fato de que referida inércia acabava por chancelar situações discriminatórias claramente vedadas pela Constituição Federal, não restava outra alternativa à Corte que não o oferecimento de uma solução, ainda que ela representasse uma prestação positiva ${ }^{182}$. Havendo direitos fundamentais envolvidos, havia consequente dever de proteção por parte do Estado que, como se negava a cumprir esse dever legislando sobre o tema, teria que passar a cumprilo em virtude de um mandamento jurisdicional.

Contudo, tratando-se de inegável prestação positiva, que poderia resvalar em críticas de excesso e ativismo judicial, o Ministro Gilmar Mendes demonstrou

\footnotetext{
${ }^{182}$ Nesse sentido é a seguinte afirmação no voto do Ministro Gilmar Mendes: "Nós estamos a falar, realmente, do reconhecimento do direito de minorias, de direitos fundamentais básicos. E, nesse ponto, não se trata de ativismo judicial, mas de cumprimento da própria essência da jurisdição constitucional."
} 
preocupação com a devida fundamentação da decisão da Corte, passando a analisar tecnicamente o pedido feito e o texto do dispositivo constitucional analisado.

Assim, considerando que a Constituição é norma aberta e que, com o desenvolvimento social ela apresenta lacunas axiológicas, há que se reconhecer a possibilidade de o Supremo Tribunal Federal realizar interpretações analógicas a fim de suprir essas lacunas, dentro do contexto aberto da Constituição, permitindo a contemplação normativa de situações já consolidadas de fato no âmbito social ${ }^{183}$.

Invocou, então, o Ministro Gilmar Mendes, a teoria do "Pensamento do Possível” como norte para a colmatação dessas lacunas. Por essa teoria, a análise das situações fáticas existentes permitiria concluir que, apesar de o texto legal parecer vedar ou não permitir uma dada interpretação, por um raciocínio analógico e reconhecendo-se a existência de uma lacuna a respeito da questão tratada, poder-se-ia adotar um resultado interpretativo aparentemente incompatível com o texto ${ }^{184}$.

E com base nesse raciocínio e também na aplicação analógica sugerida pelo voto do Ministro Ricardo Lewandowski, o Ministro acompanhou o relator, ressalvando as divergências na fundamentação já acima pontuadas.

\footnotetext{
183 Assim manifestou-se o Ministro Gilmar Mendes, in verbis: "Um outro aspecto que me parece importante de ser mencionado - eu já tive a oportunidade de destacar isso em outras ocasiões - é que, diante de um texto constitucional aberto, que exige novas aplicações, de quando em vez, nós nos encontramos diante dessas situações de lacunas, às vezes, de lacunas de caráter axiológico. Então, se por acaso não pudermos aplicar a norma tal como ela está posta, poderíamos fazê-lo numa perspectiva estritamente analógica, aplicando-a naquilo que coubesse, naquilo que fosse possível."

${ }^{184}$ Um dos exemplos que o Ministro Gilmar Mendes citou para exemplificar o uso do raciocínio do "Pensamento do Possível" na jurisprudência foi o seguinte: "No Eleitoral, eu me lembro, também, que tivemos um outro caso em que se aplicou essa mesma estrutura argumentativa. De que se cuidava? Pedido formulado por várias pessoas para que aqueles casos da chamada deficiência grave houvesse uma dispensa ou uma isenção de participação no processo eleitoral. São familiares que reclamam que determinadas pessoas estão tão doentes ou acometidas de limitações tão graves que deveria ficar isentas de participar do processo eleitoral - a cada dois anos, a obrigação de comparecer ou de fazer a justificação. A leitura do artigo 14 - diziam muitos dos colegas no Eleitoral - impossibilitava essa compreensão, porque não facultava sequer ao legislador, tal como fizera o teto anterior, essa flexibilização. De novo também, aqui citei essa indagação para dizer que o texto constitucional tornou o voto facultativo para os maiores de 70 anos, presumindo, pelo menos, uma possível limitação ou incômodo, o que parecia justificar também, na hipótese, a possibilidade de que vislumbrássemos aqui a existência de uma lacuna, de uma imperfeição, de uma incompletude que justificaria então a exceção pretendida."
} 
Em seguida, foi a vez de votar o Ministro Marco Aurélio, que iniciou o seu raciocínio pela afirmativa de que Direito e Moral e, apesar de terem cada um seus critérios, devem caminhar juntos, como deveria ocorrer na análise do caso em questão.

E mais do que isso, afirmou que, por se tratar de hipótese de nítida aplicabilidade de direito fundamental - destacando, no caso, o princípio da dignidade da pessoa humana -, sequer haveria que se considerar que a eficácia do direito estaria subordinada à atuação legislativa.

Nesse aspecto, concluiu que a aplicação dos direitos fundamentais tem caráter tipicamente contramajoritário e que compete ao Supremo Tribunal Federal realizar interpretações que privilegiem a eficácia e aplicabilidade desses direitos a todos, mas especialmente às minorias que não se veem amparadas pela legislação em vigor.

Partindo dessa premissa, então, o Ministro analisou a evolução e até mesmo a democratização do conceito de família proporcionada pela Constituição de 1988, que passou a prever como família outras entidades e construções diferentes daquela tradicionalmente constituída pelo casamento. Hoje, o patrimônio deixa de ser o valor central a definir uma família, cujas características essenciais passam a ser o amor, a afetividade e o carinho. Da mesma forma, a família passou a ser uma instituição com a "qualidade de instrumento a serviço da dignidade de cada partícipe”.

Diante disso, ressaltou o processo de viragem paradigmática do Direito Civil decorrente da chamada "constitucionalização" do direito, de forma que o direito civil e seus institutos passam a ser permeados pelos valores e princípios constitucionais, deixando o seu viés patrimonial em segundo plano e elevando à condição de centralidade o "ser".

Nesse sentido, o Estado tem a função de ajudar os indivíduos a realizar os seus projetos de vida, concretizando os postulados que decorrem da dignidade da pessoa humana, não sendo admissível a funcionalização ou instrumentalização do ser humano em função do Estado, como é costumeiro que se ocorra nos regimes totalitários ${ }^{185}$.

\footnotetext{
${ }^{185}$ Nesse sentido é interessante o seguinte trecho do voto do Ministro Marco Aurélio: “O Estado existe para auxiliar os indivíduos na realização dos respectivos projetos pessoais de vida, que traduzem o livre e
} 
Assim, com base nesses argumentos, o Ministro Marco Aurélio acompanhou o voto do Relator, e iniciou a votação o Ministro Celso de Mello.

Inicialmente, destacou o Ministro Celso de Mello que a participação ampla de amici curiae na tramitação do processo permitiu uma democratização da jurisdição constitucional que, ao final, confere legitimidade democrática à decisão que será definitivamente proferida pela Corte Constitucional.

Nesse passo, acompanhou a conclusão e a fundamentação expostas pelo Ministro Relator, ressaltando não identificar, na interpretação concreta do $\S 3^{\circ}$ do artigo 226 da $\mathrm{CF}$, nenhuma lacuna voluntária ou consciente que tivesse o condão de excluir da proteção da norma os casais homoafetivos, inclusive reforçando a mudança de paradigma da Constituição no que diz respeito ao ponto focal da entidade familiar - que passou a ser o afeto.

Assim, tendo a norma acima o sentido de inclusão, não poderia ter outra interpretação que não a de permitir e reconhecer a legitimidade das uniões estáveis homoafetivas, inclusive com supedâneo nos princípios da igualdade, liberdade, dignidade, segurança jurídica e no "postulado constitucional implícito que consagra o direito à busca da felicidade”.

Feitas essas considerações, passou também o Ministro Celso de Mello a tecer comentários sobre o papel contramajoritário do Supremo Tribunal Federal. Para ele, seria indiscutível a importância do princípio majoritário no Estado Democrático de Direito. Contudo, referido princípio deveria ser aplicado com atenuantes, uma vez que

pleno desenvolvimento da personalidade. O Supremo já assentou, numerosas vezes, a cobertura que a dignidade oferece às prestações e cunho material, reconhecendo obrigações públicas em matéria de medicamentos creche, mas não pode olvidar a dimensão existencial do princípio da dignidade da pessoa humana, pois uma vida digna não se resume à integridade física e à suficiência financeira. A dignidade da vida requer a possibilidade de concretização de metas e projetos. Daí se falar em dano existencial quando o Estado manieta o cidadão nesse aspecto. Vale dizer: ao Estado é vedado obstar que os indivíduos busquem a própria felicidade, a não ser em caso de violação ao direito de outrem o que não ocorre na espécie." 
não poderia permitir a frustração de direitos fundamentais de uma ou outra minoria, o que acabaria por desqualificar a própria essência de Estado Democrático de Direito ${ }^{186}$.

Assim, aduziu que nem os grupos majoritários podem se sobrepor aos princípios fundamentais da Constituição da República para que haja efetiva concepção democrática do Estado de Direito. E assim sendo, deve-se assegurar às minorias mecanismos de invocar a proteção de seus direitos, inclusive judicialmente.

Feitas essas considerações, o Ministro prosseguiu em seu voto insistindo na questão do direito constitucional implícito à busca da felicidade, como postulado derivado da dignidade da pessoa humana. Para ele, o neoconstitucionalismo, com seus pressupostos teóricos que reconhecem força normativa aos princípios constitucionais e primazia à jurisdição constitucional, justifica atitudes concretas no sentido de buscar a maior concretização do texto normativo da Constituição, permitindo o reconhecimento e a utilização, como vetor interpretativo, do princípio implícito da busca da felicidade.

O Ministro ainda afirmou a consonância desse posicionamento com os "Princípios de Yogyakarta", invocando norma de direito internacional a reforçar a fundamentação de voto e rejeitando, por fim, qualquer eventual acusação de ativismo judicial na posição adotada pela Corte, tendo em vista que, no caso em questão, a Suprema Corte apenas estava a cumprir o seu papel de proteção e de promoção à efetividade dos direitos fundamentais e da própria Constituição ao não aceitar a inércia do Congresso Nacional sobre a matéria.

\footnotetext{
"Práticas de ativismo judicial, embora moderadamente desempenhadas pela Corte Suprema em momentos excepcionais, tornam-se uma necessidade institucional, quando os órgãos do Poder Público se omitem ou retardam, excessivamente, o cumprimento de obrigações a que estão sujeitos, ainda mais se se tiver presente que o Poder Judiciário, tratando-se de comportamentos estatais ofensivos à Constituição, não pode se reduzir a uma posição de pura passividade.
}

\footnotetext{
186 Assim manifestou-se especificamente o Ministro Celso de Mello: "Com efeito, a necessidade de assegurar-se, em nosso sistema jurídico, proteção às minorias e aos grupos vulneráveis qualifica-se, na verdade, como fundamento imprescindivel à plena legitimação material do Estado Democrático de Direito, havendo merecido tutela efetiva, por parte desta Suprema Corte, quando grupos majoritários, por exemplo, atuando no âmbito do Congresso Nacional, ensaiaram medidas arbitrárias destinadas a frustrar o exercício, por organizações minoritárias, de direitos assegurados pela ordem constitucional (MS 24.831/DF, Rel. Min. Celso de Mello - MS 24849/DF, Rel. Min. Celso de Mello - MS 26441/DF, Rel. Min. Celso de Mello, v.g.)."
} 


\begin{abstract}
A omissão do Estado - que deixa de cumprir, em maior ou menor extensão, a imposição ditada pelo texto constitucional - qualifica-se como comportamento revestido da maior gravidade político-jurídica, eis que, mediante inércia, o Poder Público também desrespeita a Constituição, também ofende direitos que nela se fundam e também impede, por ausência (ou insuficiência) de medidas concretizadoras, a própria aplicabilidade dos postulados e princípios da Lei Fundamental, tal como tem advertido o Supremo Tribunal Federal"
\end{abstract}

Assim concluindo, acompanhou o Ministro Relator, ressaltando a importância do julgamento e do papel que o Supremo assumia então, inclusive para a salvaguarda das instituições democráticas.

Por fim, o último a votar foi o Ministro Cezar Peluso, então Presidente da Suprema Corte, o qual igualmente acompanhou a conclusão do Ministro Relator, adotando, contudo, a fundamentação do Ministro Gilmar Mendes, especialmente no reconhecimento da existência de uma lacuna no texto constitucional a ser colmatada pelos demais princípios de ordem constitucional. E concluiu o então Ministro Presidente afirmando que a decisão do Supremo não pretendia suprir a atuação legislativa, mas sim convocar o Legislativo a realizar essa atuação, de forma até mesmo a regulamentar os efeitos da decisão da Suprema Corte.

Assim, por unanimidade, o Supremo Tribunal Federal reconheceu a legitimidade das uniões estáveis homoafetivas, conferindo interpretação conforme à Constituição ao artigo 1.723 do Código Civil, ainda que por fundamentos diversos, que cada um dos Ministros especificou e que foram individualmente analisados acima.

\title{
4.3 Conclusão parcial sobre a postura do Supremo Tribunal Federal nas hipóteses
}

Analisados os primeiros julgados do primeiro bloco de direitos fundamentais, podemos agora identificar, pelos posicionamentos expostos, como se enquadra a posição do Supremo Tribunal Federal, em geral, quando instado a se manifestar sobre os direitos fundamentais da dignidade da pessoa humana, da igualdade e da isonomia.

No que diz respeito ao precedente do racismo, certamente haverá quem se posicione no sentido de que se tratou de manifestação ativista do Supremo Tribunal 
Federal na interpretação do termo "racismo" constante do texto constitucional, mormente porque se extrapolou de seu sentido semântico adotando-se interpretação mais ampla com base em análises inclusive históricas e sociológicas.

E como destacamos, o Relator para o acórdão ainda realizou uma interpretação sistemática da Constituição, analisando outros princípios de mesma hierarquia, invocando disposições gerais e principiológicas a fim de justificar o seu raciocínio mais amplo e a sua interpretação mais generosa.

E é exatamente nesse ponto que divergiremos daqueles que apontam a posição majoritária no julgamento do $\mathrm{HC} 82.424$ como ativista, pois entendemos que houve, na realidade, a aplicação correta de interpretação ampla que levou em consideração toda a gama de princípios constitucionais que permeiam o ordenamento e que devem servir de guias para a interpretação e aplicação da Constituição.

É importante também notar o aspecto de que o intérprete não está vinculado ao sentido que pretendeu o Constituinte estabelecer à norma, mormente quando a interpretação desse dispositivo de acordo com situações sociais atualizadas exige a ampliação de seu sentido.

E essa exigência de ampliação de sentido se dá em decorrência da dimensão objetiva dos direitos fundamentais e do reconhecimento de que eles formam uma ordem objetiva de valores, possuindo eficácia irradiante e impondo, ao Poder Público, deveres de proteção aos quais correspondem, para os cidadãos, direitos subjetivos de verem protegidas suas garantias fundamentais.

Como vimos acima, essa ampliação do sentido semântico do termo "racismo" configura hipótese de verdadeira mutação constitucional decorrente de interpretação, que leva em conta não só a consideração sistemática dos princípios constitucionais, como também o contexto fático e social que deve orientar as interpretações e atribuições de significado ao texto constitucional, sob pena de torna-lo engessado e subdesenvolvido e, consequentemente, correr o risco de perder efetividade e credibilidade. 
O caso em questão, é importante que se diga, traz um outro elemento que é levado em conta para justificar a interpretação ampliada do texto constitucional que prevaleceu como tese vencedora. Estamos nos referindo à repercussão social do tema e à possibilidade de se construir, na interpretação em questão, uma jurisprudência simbólica, a transmitir à sociedade a mensagem de que o Supremo Tribunal Federal será intolerante com qualquer discriminação, interpretando de forma ampla o dispositivo sobre a imprescritibilidade e não hesitando em adotar uma postura ativa para preservar a dignidade da pessoa humana e o princípio da não discriminação.

Ora, esse próprio viés adotado pela Corte no julgamento desse HC não necessariamente se repetiria em outras situações, pois não se configura como um comportamento típico facilmente perceptível em relação à interpretação de outros termos aparentemente bem definidos e com pouco espaço de conformação, podendo ser até mesmo identificados como enunciados dogmáticos.

Da mesma forma, certamente que a decisão teria sido muito mais objeto de críticas dos opositores do ativismo judicial caso a matéria versada fosse outra, de menos impacto social e indiscutível apelo popular.

Não obstante todos esses aspectos, entendemos ser plenamente aceitável e correta a interpretação conferida pelo STF ao caso, e não concordamos ter havido posição ativista por parte da Corte, tendo em vista que ela agiu dentro das balizas de atuação que lhe foram definidas pela própria Constituição, utilizando justificações externas amplas, com base em interpretações sistemáticas de princípios, enunciados dogmáticos e argumentos empíricos, sempre dentro da configuração constitucional como condicionada por uma ordem objetiva de valores composta pelos direitos fundamentais.

Consideramos, todavia, que apesar de não se ter configurado ativismo judicial - não obstante tenhamos verificado postura ativa da Corte -, houve mutação constitucional, a qual é salutar por permitir a adaptação da Constituição às realidade sociais mutantes e consolidadas e por proporcionar mais eficácia aos princípios constitucionais interpretados como um todo único. 
Por fim, também nos pareceu absolutamente correto o raciocínio de ponderação adotado pelo Ministro Gilmar Mendes em relação aos direitos de liberdade de expressão e igualdade, tendo ele afirmado a indiscutível prevalência do último em relação ao primeiro, tendo em vista que dessa forma seria possível preservar o conteúdo de ambos, ao passo que se fosse dada prevalência ao direito à liberdade de expressão no caso, negar-se-ia validade a qualquer conteúdo da igualdade, o que não poderia ser autorizado por um juízo de ponderação corretamente realizado, nos termos que já explicamos acima.

Entendemos que o juízo de ponderação realizado pelo Ministro Gilmar Mendes mostrou-se mais racionalmente fundamentado do que aquele realizado pelo Ministro Ayres Britto que, sopesando os mesmos princípios em conflito, decidiu que no caso concreto dever-se-ia privilegiar o postulado da liberdade de expressão, uma vez que o conteúdo divulgado no livro de autoria do Paciente veiculava apenas uma ideologia e não propriamente um preconceito. E sendo a divulgação de ideologia também assegurada pela Constituição e postulado da própria ideia republicana de governo, entendeu o último Ministro pela preservação do princípio da liberdade de expressão com restrições ao da igualdade.

Votou no mesmo sentido, realizando a mesma ponderação de valores, o Ministro Marco Aurélio. Apesar de afirmar, na esteira dos votos majoritários, que de fato o termo "racismo" deveria ser interpretado de forma ampla e a despeito de aceitar que a publicação de livros poderia ser considerada uma forma de incitação ao racismo, o Ministro entendeu que, na análise do caso concreto, não se poderia afirmar que o conteúdo das publicações do Paciente estivesse enquadrado na hipótese de racismo.

Certamente essa divergência entre os dois ministros na realização do mesmo juízo de ponderação entre os mesmos princípios em jogo traria supostos argumentos aos críticos do método sob o fundamento de que os resultados divergentes provariam a ausência de racionalidade da técnica de interpretação em questão.

Contudo, desde logo rechaçamos essa crítica, tendo em vista que a mera divergência nos resultados da ponderação não podem significar a falta de racionalidade do procedimento, mesmo porque, conforme demonstramos acima, Robert Alexy, 
defensor dessa técnica, sequer admite a existência de uma única resposta correta para uma questão controversa. Portanto, não pretende a ponderação conferir ao caso concreto esse único resultado possível - que inexiste -, mas sim fornecer elementos de fundamentação e convicção que, se corretamente utilizados, podem chegar a resultados válidos, uma vez que racionalmente fundamentados, ainda que divergências sejam possíveis e continuem sempre a existir.

Também em relação ao segundo caso que analisamos e que tratou da união estável homoafetiva, é certo que os críticos do ativismo provavelmente vão apontar características de interpretação ampliativa do texto constitucional, com suposta extrapolação dos limites e balizas semânticos definidos e com a atribuição de significados inexistentes a expressões que permitem pouca margem de interpretação.

Todavia, no esforço de fundamentar racionalmente a sua posição, o Ministro Relator Ayres Britto afirmou que o silêncio da Constituição acerca do direito à liberdade sexual era eloquente na medida em que significava a plena liberdade de escolha nessa área, protegida e assegurada pelo documento constitucional, inclusive no artigo em que previa a vedação à discriminação pelo sexo (artigo $3^{\circ}$, inciso IV).

E fundado, novamente, em princípios e direitos fundamentais constitucionalmente previstos, em especial o da autonomia da vontade, da vedação à discriminação e da dignidade da pessoa humana, o Ministro realizou uma interpretação extensiva do conceito constitucional de família, afirmando que o termo deveria ser entendido em seu significado mais amplo, abrangendo quaisquer espécies de vínculos familiares, todos eles sujeitos a proteção estatal.

Observa-se aqui, mais uma vez, o recurso da Corte aos princípios constitucionais a fim de fazer valer a interpretação mais condizente com a realidade social e, porque não, mais consentânea com os valores assegurados pela Constituição Federal.

Portanto, mais uma vez aqui, no ponto em que os críticos enxergam ativismo pelo recurso extenso a princípios constitucionais a fim de se interpretar dispositivos legais aparentemente concretos o suficiente para não exigir interpretação 
extensiva, nós enxergamos atuação regulamentar, dentro dos parâmetros autorizados pela Constituição e absolutamente recomendáveis para fins de assegurar a sua força normativa, tendo em vista a importância e prevalência que os direitos fundamentais devem ter sobre os demais princípios, sendo eles pressupostos do Estado de Direito que a Constituição pretende promover e proteger.

Da mesma forma, considerou o Relator que sequer se vislumbrava o conflito dos direitos fundamentais em foco com qualquer outro direito de mesma hierarquia, tratando-se somente de se conferir plena eficácia aos postulados da igualdade e da dignidade da pessoa humana, sem qualquer restrição a nenhum outro direito ou garantia de igual hierarquia.

Esse é mais um dos motivos pelos quais entendemos que também aqui não se cabe falar em ativismo judicial. É evidente, todavia, que o Judiciário atuou, no caso em questão, de forma ativa, buscando fundamentar a possibilidade da união estável homoafetiva em interpretação conjunta, sistemática e de eficácia aditiva de diversos dispositivos constitucionais, notadamente aqueles revestidos de caráter principiológico, como o da dignidade da pessoa humana, da igualdade e até mesmo da isonomia.

Também aqui vislumbrou-se justificação externa perfeitamente fundamentada, com o recurso a argumentos de interpretação legal e principiológica, enunciados dogmáticos, argumentos empíricos, históricos, genéticos e comparativos, tudo a reforçar a racionalidade do resultado a que chegaram os Ministros do Supremo Tribunal Federal.

É importante ressaltar que a prestação positiva assumida pela Corte nesse julgamento teve plena justificativa na inércia do Legislativo, que não obstante possuísse diversos projetos sobre a matéria aguardando votação, permanecia insensível à questão. E essa inércia -- por permitir que direitos fundamentais restassem desguarnecidos -- deveria ser suprida pelo provimento jurisdicional buscado, mormente porque o Estado possui dever de proteção dos direitos fundamentais, ao qual correspondem direitos subjetivos dos cidadãos a verem seus direitos efetivamente garantidos e promovidos, reclamando provimentos jurisdicionais. 
Além disso, os direitos fundamentais, por força até de disposição expressa da Constituição, não dependem de regulamentação legislativa para sua plena eficácia.

Nesse ponto, vale até uma reflexão sobre a efetiva representatividade do Legislativo, que mesmo confrontado com a necessidade de examinar a questão, por pressão de diversos setores sociais, preferiu deixa-la adormecida sem qualquer resposta, ao passo que o Judiciário, também pressionado pelos mesmos setores sociais, teve de suprir essa omissão e posicionar-se sobre o caso.

O Supremo Tribunal Federal, instigado que foi a se manifestar, não poderia ter adotado postura diversa e quedado inerte como o legislador sob o argumento de que eventual atuação estaria em confronto com a supremacia legislativa, a qual já demonstramos acima ser absolutamente improcedente.

No nosso entender, não há que se falar, por nenhum dos motivos alegados acima, que a postura adotada pelo Supremo tenha sido ativista, pois tratou-se meramente de postura ativa, necessária à guarda dos princípios da igualdade e da dignidade da pessoa humana.

Não obstante não se tenha configurado ativismo judicial, acreditamos que houve, também nesse caso, mutação constitucional, notadamente no que se refere à interpretação não propriamente do conceito de família, mas do conceito de união estável, mormente tendo em vista que o texto constitucional é claro ao estabelecer restrição desse instituto a uma relação sócio-afetiva constituída por “um homem e uma mulher”.

É certo que nesse ponto não se pode negar a configuração de mutação constitucional, com a alteração e expansão do conceito já constitucionalmente definido de união estável, para fazer abranger, novamente em resposta aos anseios sociais há muito consolidados, o direito das famílias homoafetivas.

Acreditamos que aqui, também, é possível vislumbrar um traço da chamada "jurisprudência simbólica" invocada pelo Ministro Marco Aurélio no julgamento do habeas corpus acima analisado, mormente porque não só houve uma interpretação extensiva e abrangente, como também uma própria alteração no sentido do 
texto escrito de forma claramente restritiva que, contudo, foi superada por considerações históricas, sociais e relativas à preservação da dignidade da pessoa humana.

A atuação contramajoritária do Supremo no caso em questão se revela incontestável, mas decorre, ao nosso ver, da própria dimensão objetiva dos direitos fundamentais, já amplamente abordada acima, a qual torna o Estado devedor do cidadão no sentido de lhe proporcionar proteção aos seus direitos fundamentais frente ao próprio Estado e também frente aos particulares. Vale dizer que esse também foi o raciocínio do Ministro Luiz Fux na assentada.

Em resumo, todos esses pontos em comum entre ambos os julgados -notadamente a posição ativa adotada pelo Supremo na interpretação de institutos jurídicos cujo significado parecia dotado de concretude tal que não permitiria a sua interpretação extensiva -- levam-nos a concluir que, quando em jogo a preservação de princípios de alto calibre como o são o da dignidade da pessoa humana e o da igualdade, o Supremo está disposto a realizar interpretações mais amplas, promovendo verdadeira mutação constitucional ao conferir sentidos adicionais a dispositivos aparentemente bem definidos semanticamente.

Portanto, ao nosso ver, referida postura diante dos princípios em jogo é absolutamente justificável e está em conformidade com as balizas de atuação definidas pelo ordenamento jurídico, demonstrando um Judiciário de caráter ativo, mas não ativista. 


\section{DO DIREITO FUNDAMENTAL À PRESUNÇÃO DE INOCÊNCIA}

-- INTERPRETAÇÃO DO SUPREMO TRIBUNAL FEDERAL ACERCA DO INCISO LVII, DO ARTIGO 5 ${ }^{\circ}$ DA CONSTITUIÇÃO FEDERAL

O postulado da presunção de inocência - ou da não-culpabilidade - é condição de qualquer Estado Democrático de Direito e é previsão constitucional em qualquer sociedade que se pretende livre e justa, uma vez que é pressuposto de limitação das arbitrariedades estatais e respeito ao indivíduo ${ }^{187}$.

Referido princípio foi positivado na Constituição Federal de 1988 no inciso LVII, do artigo $5^{\circ}$, que dispõe que "ninguém será considerado culpado até o trânsito em julgado de sentença penal condenatória”.

Como veremos a seguir, pela análise de dois julgados do Supremo Tribunal que examinaram o princípio em questão, os seus desdobramentos tendem a acarretar fortes reações populares, as quais podem ou não influenciar o posicionamento da Suprema Corte quanto à efetividade do princípio em questão.

Por essa razão, escolhemos os dois acórdãos que serão aqui analisados. No primeiro deles, em que foi julgado o $\mathrm{HC} \mathrm{n}^{\circ}$ 84.078/MG, o Supremo Tribunal Federal consolidou novo posicionamento, superando seu entendimento anterior, de máxima efetividade à presunção de inocência, passando a impedir a chamada execução antecipada da pena, consignando que todos os acusados deveriam ter respeitado o direito de responder ao processo em liberdade até o seu trânsito em julgado, independentemente de os recursos pendentes possuírem ou não efeito suspensivo.

É possível perceber que o posicionamento em questão desencadeia, no caso concreto, fortes reações sociais, mormente porque a análise crua das suas consequências iniciais pode muitas vezes soar como manutenção ou chancela da

${ }^{187}$ A esse respeito, ver MORAES, Alexandre de. Direito Constitucional. São Paulo: Atlas, 2009. pp. 118119. E, ainda, MENDES, Gilmar Ferreira; COELHO, Inocêncio Mártires e BRANCO, Paulo Gustavo Gonet. Curso de Direito Constitucional. São Paulo: Saraiva, 2007. pp. 593-602 
impunidade. Contudo, mesmo considerando esses aspectos, o STF consolidou esse novo entendimento, hoje vigente.

O segundo acórdão que analisaremos, por sua vez, mostrou uma Corte mais atenta e mais responsiva aos anseios sociais, tendo havido relativização inconteste do princípio da presunção de inocência, inclusive sob a alegação de que a vontade popular exigia esse posicionamento da Corte naquela situação.

Trata-se, aqui, do julgamento a respeito da constitucionalidade material da Lei da Ficha Limpa, em que focaremos principalmente no posicionamento dos Ministros acerca da adequação dos preceitos legais que previam a possibilidade de se tornarem inelegíveis candidatos ainda não condenados definitivamente, na esfera eleitoral, criminal ou administrativa.

Assim, com a escolha dos dois julgados acima, buscaremos identificar qual tem sido a postura do Supremo Tribunal Federal acerca do princípio da presunção da inocência, quais têm sido os limites impostos ao exercício e à eficácia desse direito e, principalmente, quais fatores têm sido utilizados pela Corte na sua aplicação, na sua interpretação e na promoção de sua plena eficácia.

\subsection{Do julgamento do $\mathrm{HC}^{0}$ 84.078/MG}

Iniciaremos com o exame do Habeas Corpus $n^{\circ} 84.078$, em que o Tribunal Pleno, conforme já adiantamos, modificou o entendimento anteriormente consolidado da Corte, para consignar que o respeito ao princípio da presunção de inocência deveria impedir a execução antecipada da pena, passando o acusado a ter o direito de responder em liberdade a todo o processo criminal, até o seu trânsito em julgado, independentemente de os recursos pendentes possuírem ou não efeito suspensivo.

Em seu voto, o Ministro Relator Eros Grau levantou a necessidade de, a seu ver, modificar-se o posicionamento tradicional do STF no sentido de que, havendo acórdão condenatório e pendentes apenas os recursos de índole extraordinária - não dotados de efeito suspensivo -, seria possível antecipar a execução da pena restritiva de liberdade, mesmo que não estivesse configurado ainda o trânsito em julgado. 
Invocou, então, inicialmente, a preponderância do dispositivo da Lei de Execuções Penais (Lei $\left.n^{0} 7.210 / 84\right)^{188}$ que previa a possibilidade de execução da pena somente com o advento do trânsito em julgado do processo, afirmando que esse preceito legal se sobreporia ao restritivo do artigo 637 do Código de Processo Penal (Decreto-lei $\left.\mathrm{n}^{\mathrm{o}} 3.689 / 41\right)^{189}$, tanto por ser compatível com a Constituição, quanto temporalmente.

Superado o argumento eminentemente legal, passou a asseverar o Ministro Relator que o princípio da presunção da inocência era claro ao prever a possibilidade de se executar a pena apenas com o trânsito em julgado do processo, sob pena de se configurar um desequilíbrio entre o interesse estatal de aplicar a punição e o direito da defesa de elidir a culpabilidade defendendo-se até as suas últimas possibilidades.

Assim, para o Ministro Relator, o princípio da presunção de inocência estaria até mesmo intimamente ligado ao princípio da ampla defesa, uma vez que a ampla eficácia desse último princípio também impediria que se executasse a pena antes que se permitisse ao acusado usar de todos os meios possíveis para a sua defesa, fossem eles recursos de índole extraordinária ou não, tivessem eles ou não efeito suspensivo.

Pontuou ainda o Ministro Eros Grau que essa interpretação seria igualmente corolário lógico do princípio da isonomia de direitos entre os acusados aos quais tivesse sido imposta pena restritiva de liberdade e aqueles que houvessem enfrentado penas restritivas de direitos, mormente porque, quanto a esses últimos, o Supremo já não aceitava a execução antecipada da pena, a despeito da gravidade menor da penalidade aplicada.

Em seguida, lembrou o Relator que os oponentes da nova interpretação que pretendia ele conferir ao princípio da presunção de inocência acabariam por criticar esse posicionamento sob o argumento de que os Tribunais Superiores passariam a ser inundados de recursos e que não se veriam mais prisões, chancelando-se a impunidade.

\footnotetext{
${ }^{188}$ Art. 105. Transitando em julgado a sentença que aplicar pena privativa de liberdade, se o réu estiver ou vier a ser preso, o Juiz ordenará a expedição de guia de recolhimento para a execução.

189 Art. 637. O recurso extraordinário não tem efeito suspensivo, e uma vez arrazoados pelo recorrido os autos do traslado, os originais baixarão à primeira instância, para a execução da sentença.
} 
Todavia, a esses críticos, já respondeu adiantadamente o Relator, quando afirmou que o Supremo Tribunal Federal tinha exatamente o papel de apontar as inconstitucionalidades existentes nos dispositivos legais, mormente quando eles refletissem positivação oriunda de reações sociais casuísticas, de momentos de revolta e de pouca reflexão acerca dos primados constitucionais.

Ressaltou, então, o Ministro Relator, a postura que deveria o Supremo Tribunal Federal tomar em situações em que os anseios populares, ainda que refletidos em legislação efetivamente aprovada pelo Congresso Nacional $^{190}$, conflitassem com princípios e garantias constitucionais:

\footnotetext{
"É bom que estejamos bem atentos, nesta Corte, em especial nos momentos de desvario, nos quais as massas despontam na busca, atônita, de uma ética -qualquer ética -- o que irremediavelmente nos conduz ao 'olho por olho, dente por dente'. Isso nos incumbe impedir, no exercício da prudência do direito, para que prevaleça contra qualquer outra, momentânea, incendiária, ocasional, a força normativa da Constituição. Sobretudo nos momentos de exaltação. Para isso fomos feitos, para tanto aqui estamos."
}

E no mesmo passo, afirma o Relator que não se pode usar a conveniência dos Tribunais Superiores no recebimento de cada vez menos recursos para se justificar a relativização da aplicação de uma garantia constitucional. Afirma ele que não se pode utilizar a jurisprudência defensiva para se limitar ou até mesmo amputar direitos fundamentais constitucionalmente previstos.

Frisa também o Ministro Eros Grau a íntima relação entre o princípio da presunção de inocência e o Estado Democrático de Direito, afirmando que nas democracias também os criminosos devem ser considerados sujeitos de direito e a Constituição e suas garantias devem valer para todos.

Assim, votou o Ministro pela concessão da ordem e pela fixação do entendimento de que, pela aplicação do princípio da presunção de inocência, seria inconstitucional qualquer dispositivo na legislação brasileira que permitisse a execução

190 O Ministro Relator citou como exemplos desse "casuísmo do legislador" a aprovação da Lei $\mathrm{n}^{\mathrm{o}}$ 8.072/90 - lei dos crimes hediondos - e da Lei $\mathrm{n}^{\circ}$ 8.038/90 - que regula os processos nos tribunais superiores -, mencionando que ambas decorreram das reações populares aos episódios de sequestro do empresário Abílio Diniz e de Roberto Medina. 
antecipada da pena, sendo permitida essa execução apenas com o trânsito em julgado do processo condenatório.

Levantada a questão pelo Ministro Relator, mormente no tocante à proposta de alteração do entendimento que até então prevalecia na Corte - apesar de haver divergências entre as duas Turmas, o Ministro Menezes Direito pediu vistas do processo e inaugurou divergência com o Ministro Relator, manifestando-se favoravelmente à manutenção do posicionamento tradicional da Corte quanto à matéria.

Argumentou, para tanto, que a interpretação que vedasse a execução da pena quando pendentes apenas os recursos de índole extraordinária não dotados de efeito suspensivo acabaria aplicando, por interpretação, efetivo efeito suspensivo a esses recursos. Além do mais, arguiu que havia compatibilidade entre o princípio da presunção de inocência e a execução antecipada da pena, tanto que se admitia a prisão cautelar para garantir a persecução penal e, sendo o acórdão definitivo condenatório, mais razão ainda haveria para se assegurar a sua eficácia permitindo desde logo o início da execução da pena.

Alegou, também, com base em precedentes antigos da Corte que invocou, que a Convenção Americana Sobre Direito Humanos, apesar de assegurar o princípio da presunção de inocência, não assegura ao condenado o direito de recorrer sempre em liberdade.

Invocou, então, os magistérios de Ronald Dworkin e Robert Alexy para afirmar que os princípios ou se aplicam, ou não se aplicam e, quando aplicáveis, devem promover sempre o mesmo resultado para situações equivalentes. Assim, segundo o raciocínio do Ministro Menezes Direito, tanto a execução provisória da pena quanto a possibilidade de prisões cautelares seriam situações idênticas, pois ambas permitiriam aplicação de penalidade antes do trânsito em julgado. Assim, como não se considera a possibilidade de prisão cautelar inconstitucional, pela coerência na aplicação dos princípios, segundo o Ministro Menezes Direito, também não seria possível considerar inconstitucional a chamada execução antecipada da pena. 
Justificou ainda o seu posicionamento no duplo caráter da sanção penal, afirmando que a execução provisória da pena seria um desdobramento do caráter preventivo da pena, aceito inclusive em países de caráter liberal, o que retiraria dela qualquer viés autoritário.

Por fim, utilizou como fundamento de sua posição a constatação de que o impedimento de se realizar a execução antecipada da pena apenas iria incentivar manobras protelatórias por parte das defesas, principalmente aquelas tendentes a buscar a configuração da prescrição. E manifestou ainda a existência de um conflito, a ser solucionado com a aplicação do princípio da proporcionalidade, entre a proibição de excesso e a proibição de proteção deficiente, em que esse último deveria prevalecer para permitir a execução antecipada da pena.

Em seguida, votou o Ministro Celso de Mello, que iniciou por afirmar que a prisão cautelar, em qualquer uma das suas modalidades, é medida excepcional apenas passível de deferimento mediante decisão efetivamente fundamentada com a demonstração do atendimento inequívoco aos pressupostos legais.

Ademais, ressaltou o Ministro, a prisão cautelar não teria função punitiva, mas simplesmente de preservação da efetividade do processo penal, de forma que, não tendo ela essa função de punição, não poderia ser utilizada para executar antecipadamente pena aplicada por decisão condenatória ainda recorrível.

Reiterou o Ministro Celso de Mello o mesmo posicionamento do Ministro Relator no sentido de que o cidadão submetido à persecução penal permanece sujeito de direitos que devem ser preservados pelos magistrados e Tribunais, especialmente pelo STF, guardião da Constituição, sendo certo que dentre esses direitos encontra-se o postulado da presunção de inocência segundo o qual nenhum indivíduo poderá ser considerado culpado antes do trânsito em julgado de decisão penal condenatória.

Continuou afirmando que o entendimento do Supremo Tribunal Federal acerca da aplicação do princípio da presunção de inocência - inclusive no julgamento da 
ADPF $144^{191}$ - apenas garantia a força normativa da Constituição e sua supremacia e era corolário lógico do próprio princípio democrático.

Ressaltou, ainda, o Ministro Celso de Mello, que o princípio da presunção de inocência não seria esvaziado progressivamente na medida em que se sucederiam os graus de jurisdição, de forma que não se poderia condicionar a sua aplicação até a prolação do acórdão, relativizando-o enquanto perdurassem os recursos de índole extraordinária, sob pena de lhe negar vigência e eficácia plenas.

Assim, acompanhou integralmente o voto do Ministro Relator.

Em seguida, acompanhando a divergência, votou o Ministro Joaquim Barbosa, que destacou que se filiava ao entendimento tradicional da Corte, sob pena de não se reconhecer a legitimidade das instâncias ordinárias para proferir decisões condenatórias efetivas e de ser criar estado de impunidade.

Destacou ainda o Ministro Joaquim Barbosa que o princípio da não culpabilidade deveria ser interpretado de forma a conciliar-se o seu significado com a regra constitucional da repercussão geral, ponderando aquele valor com a restrição de conhecimento de matérias, pelo Supremo Tribunal Federal, que transcendam o mero interesse subjetivo.

O próximo a votar foi o Ministro Ayres Britto, que acompanhou o relator e votou pela concessão da ordem. Argumentou o Ministro que a liberdade de ir e vir é um valor caro à Constituição, que o privilegia sobremaneira e que prevê poucas e pontuais exceções à sua preservação. Ainda, afirmou que a possibilidade de efetivar-se a prisão cautelar seria um meio de conciliar o valor da liberdade com o da eficácia da persecução penal, não havendo justificativa para se permitir a execução antecipada da pena.

No mesmo sentido foi o posicionamento do Ministro Cezar Peluso. Partiu ele de um raciocínio histórico, indicando que o princípio ora analisado primeiramente

${ }^{191}$ No julgamento dessa ADPF, o STF definiu a aplicabilidade do princípio da presunção de inocência também em âmbito eleitoral. Contudo, conforme será visto na análise do próximo julgado, esse entendimento foi posteriormente superado especificamente no tocante ao âmbito eleitoral. 
havia sido concebido como uma garantia do indivíduo contra o processo estatal, passando posteriormente a ser uma discussão acerca do modelo de processo que o Estado deveria adotar, para então finalmente girar em torno da definição do ônus da prova no processo penal.

Em cada uma dessas fases - todas elas incorporadas ao significado atual do princípio - acrescentou-se uma característica específica, de forma a se conceituar, ao final, o princípio da não culpabilidade como uma valor político-ideológico para garantir a tutela da dignidade da pessoa humana. Nesse sentido, afirmou o Ministro Cezar Peluso em seu voto:

\footnotetext{
"Diante desse quadro, o conteúdo jurídico do princípio é, nada mais nada menos, que a expressão de uma garantia no sentido substancial, não no sentido de remédio processual; no sentido substancial de o ordenamento jurídico, em relação ao réu, não the poder impor nenhuma medida que atinja sua esfera ou patrimônio jurídico, no sentido largo do termo, enquanto não sobrevenha sentença definitiva condenatória. Ou seja, o ordenamento jurídicoconstitucional não tolera, por força do princípio, que o réu, no curso do processo penal, sofra qualquer medida gravosa, cuja justificação seja um juízo de culpabilidade que ainda não foi emitido em caráter definitivo. Toda medida que se aplique, mediante lei, ao réu, no curso do processo, e que não possa ser justificada ou explicada por outra causa jurídica, senão por um juízo de culpabilidade, ofende a garantia constitucional."
}

Por fim, utilizou-se do princípio do devido processo legal para afirmar o conteúdo do princípio da presunção de não culpabilidade, esclarecendo que, a seu ver, o devido processo legal não significa apenas o atendimento à lei e aos pressupostos regulamentares do processo, mas também à justiça do seu proceder. E sendo a justiça pressuposto constitucional de validade dos processos, certamente não se poderia considerar a execução antecipada da pena - absolutamente injusta - como compatível com os princípios constitucionais em questão.

Encerrado o voto do Ministro Cezar Peluso, votou a Ministra Ellen Gracie que também houve por bem acompanhar a divergência inaugurada pelo Ministro Menezes Direito. Para ela, a afirmação de que os valores da preservação da ordem pública e efetividade da persecução penal estariam preservados por meio da possibilidade de se decretar prisão cautelar seria improcedente. Isso porque as hipóteses de prisão cautelar dificilmente se configurariam no caso de execução provisória de sentença ou acórdão condenatórios, tendo em vista a dificuldade de se configurar hipótese de proteção 
à ordem pública ou à ordem econômica, a inaplicabilidade da prisão para assegurar a instrução penal (que já terá sido encerada), restando apenas a possibilidade de prisão cautelar para assegurar a aplicação da lei penal.

Votou, então, o Ministro Marco Aurélio, acompanhando o Relator e ressaltando que a execução provisória é permitida no âmbito patrimonial, principalmente porque há a hipótese de se prestar caução ou de se devolver o bem dado como garantia da execução. Contudo, não há como se devolver ao condenado injustamente a liberdade que ele perdeu no momento da execução provisória da pena, sendo evidente o conflito entre essa possibilidade e o princípio da presunção de inocência.

Por fim, votou o então Ministro Presidente, Gilmar Mendes, também acompanhando o Relator e ressaltando a possibilidade de mudança de entendimento pelo Supremo Tribunal Federal, ainda que o posicionamento anterior estivesse consolidado há mais de 20 anos na Corte. Ressaltou a ausência de vinculação do Tribunal aos seus posicionamentos anteriores e mencionou que a interpretação constitucional deve se dar de forma dinâmica, ainda que sempre observando a tensão entre sua adequação com o tempo atual e a segurança jurídica e previsibilidade de seus pronunciamentos.

Ressaltou, o Ministro Gilmar Mendes, que o postulado da presunção de inocência é consequência não só do devido processo legal, mas também da dignidade da pessoa humana, sendo inclusive indicativo de efetividade do Estado Democrático de Direito, diferenciando civilização de barbáries.

Da mesma forma, utilizou-se da análise do princípio da proporcionalidade - ou da proibição do excesso - para afirmar que existe um limite até o qual pode ser relativizada a norma de direito fundamental, mas a partir do qual é impossível qualquer relativização, sob pena de desnaturar-se o princípio em questão.

Realizando juízo de ponderação pautado sobre os postulados do princípio da proporcionalidade - adequação, necessidade e proporcionalidade em sentido estrito - o Ministro analisou se os mandamentos legais de recolhimento do acusado à prisão após acórdão condenatório e quando pendentes apenas recursos de índole extraordinária, frente 
ao postulado do princípio da inocência, permitiriam flexibilização proporcional, adequada e necessária.

Para ele, não haveria necessidade da execução provisória da pena mormente tendo em vista as previsões legais de prisão cautelar - o que significaria que qualquer medida nesse sentido não seria adequada à Constituição, de forma que a execução antecipada da sentença condenatória violaria não só o postulado da presunção de inocência, mas também os princípios da dignidade da pessoa humana e da proporcionalidade.

Por fim, retornando à análise da mudança de jurisprudência consolidada no Supremo Tribunal Federal por meio do julgamento em questão, o Ministro Gilmar Mendes foca no ensinamento de Häberle no sentido de que qualquer norma somente é norma quando interpretada. E sendo as construções todas dependentes da interpretação, são naturalmente mutáveis, junto com a realidade, as circunstâncias e os contextos, sendo evidente o condicionamento da interpretação a esses aspectos e, consequentemente, sendo a mutação constitucional derivada naturalmente desse processo natural de mudanças interpretativas $^{192}$.

E por fim ressaltou o Ministro que esse fenômeno da mutação constitucional é ainda mais evidente quando se trata da interpretação de direitos fundamentais, citando exemplos do direito comparado, mais especificamente nos Estados Unidos e na Alemanha.

Assim, finalizada a votação, foi concedida a ordem de habeas corpus por maioria de votos, vencidos os Ministros Menezes Direito, Carmen Lúcia, Joaquim Barbosa e Ellen Gracie.

O julgamento acima, além das diversas interpretações sobre o princípio constitucional da presunção de inocência é muito interessante para os objetivos do

\footnotetext{
${ }^{192}$ Em seu voto, assim se manifesta o Ministro Gilmar Mendes a esse respeito: "Tal concepção permite a Häberle afirmar que, em sentido amplo, toda lei interpretada - não apenas as chamadas leis temporárias - é uma lei de duração temporal limitada (...). Em outras palavras, o texto, confrontado com novas experiências, transforma-se necessariamente em um outro."
} 
presente trabalho, porque suscita não só questões de conflito de valores, ponderação de princípios e interpretação constitucional.

Ele é interessante também porque implica a mudança de um entendimento consolidado há mais de 20 (vinte) anos perante o Tribunal, que pode ser considerado uma verdadeira mutação constitucional - ainda que tenha havido mera reinterpretação de princípios e normas e não propriamente alteração do texto constitucional.

E também no mesmo sentido é interessante o julgado que analisaremos em seguida, ainda sob o enfoque do princípio da presunção de inocência, em que se refletirá uma outra forma de mutação constitucional, por outras razões, podendo se vislumbrar uma postura ainda diferente do Supremo Tribunal Federal, por mais que estivesse diante do mesmo princípio constitucional e por mais que o resultado de sua interpretação também implicasse, ao final, uma mutação constitucional. É o que veremos em seguida.

\subsection{Do julgamento da constitucionalidade da Lei da Ficha Limpa}

Quando da análise das ADCs n 29 e 30 em conjunto com a ADI n ${ }^{\circ} 4.578$, no que tange ao princípio da presunção de inocência, o Supremo Tribunal Federal analisou se as novas hipóteses de inelegibilidade criadas pela Lei Complementar $n^{\circ}$ 135/10, notadamente aquelas que incluíam a expressão "ou proferida por órgão colegiado $^{193}$ afrontariam esse princípio constitucional, ou se estariam em conformidade com o quanto previsto no artigo $14, \S 9^{\circ}$, da Constituição Federal ${ }^{194}$.

${ }^{193}$ Art. $1^{\circ}$ São inelegíveis:

I - para qualquer cargo: (...)

d) os que tenham contra sua pessoa representação julgada procedente pela Justiça Eleitoral, em decisão transitada em julgado ou proferida por órgão colegiado, em processo de apuração de abuso do poder econômico ou político, para a eleição na qual concorrem ou tenham sido diplomados, bem como para as que se realizarem nos 8 (oito) anos seguintes;

e) os que forem condenados, em decisão transitada em julgado ou proferida por órgão judicial colegiado, desde a condenação até o transcurso do prazo de 8 (oito) anos após o cumprimento da pena, pelos crimes:

1. contra a economia popular, a fé pública, a administração pública e o patrimônio público;

2. contra o patrimônio privado, o sistema financeiro, o mercado de capitais e os previstos na lei que regula a falência;

3. contra o meio ambiente e a saúde pública;

4. eleitorais, para os quais a lei comine pena privativa de liberdade;

5. de abuso de autoridade, nos casos em que houver condenação à perda do cargo ou à inabilitação para o exercício de função pública;

6. de lavagem ou ocultação de bens, direitos e valores;

7. de tráfico de entorpecentes e drogas afins, racismo, tortura, terrorismo e hediondos;

8. de redução à condição análoga à de escravo; 
Dentre todas as hipóteses em questão, uma delas foi de maior interesse para o exame da suposta ofensa ao princípio. Trata-se da previsão de que tornar-se-iam inelegíveis os cidadãos que houvessem sido condenados por um órgão colegiado independentemente dessa condenação ser definitiva ou não - por ilícitos penais, eleitorais, ou de improbidade administrativa.

Como se percebe do dispositivo acrescentado pela Lei Complementar $n^{\circ}$ 135/10, o legislador promoveu uma flexibilização do princípio da presunção de inocência ao permitir que se aplicasse ao cidadão uma sanção - a de não poder se candidatar, alijando-o da plena participação do processo político - antes mesmo que se confirmasse essa condenação como definitiva.

Essa inovação legislativa, frente à jurisprudência até então consolidada pelo Supremo Tribunal Federal - especialmente em julgados como o analisado acima aparentava ter todas as características de inconstitucionalidade a serem reconhecidas pelo Tribunal no momento em que provocado.

Todavia, surpreendentemente, a Corte Suprema entendeu constitucional o referido dispositivo, mediante uma análise que pode ser resumida da seguinte forma.

9. contra a vida e a dignidade sexual; e

10. praticados por organização criminosa, quadrilha ou bando;(...)

h) os detentores de cargo na administração pública direta, indireta ou fundacional, que beneficiarem a si ou a terceiros, pelo abuso do poder econômico ou político, que forem condenados em decisão transitada em julgado ou proferida por órgão judicial colegiado, para a eleição na qual concorrem ou tenham sido diplomados, bem como para as que se realizarem nos 8 (oito) anos seguintes;(...)

j) os que forem condenados, em decisão transitada em julgado ou proferida por órgão colegiado da Justiça Eleitoral, por corrupção eleitoral, por captação ilícita de sufrágio, por doação, captação ou gastos ilícitos de recursos de campanha ou por conduta vedada aos agentes públicos em campanhas eleitorais que impliquem cassação do registro ou do diploma, pelo prazo de 8 (oito) anos a contar da eleição; (...)

1) os que forem condenados à suspensão dos direitos políticos, em decisão transitada em julgado ou proferida por órgão judicial colegiado, por ato doloso de improbidade administrativa que importe lesão ao patrimônio público e enriquecimento ilícito, desde a condenação ou o trânsito em julgado até o transcurso do prazo de 8 (oito) anos após o cumprimento da pena; (...)

p) a pessoa física e os dirigentes de pessoas jurídicas responsáveis por doações eleitorais tidas por ilegais por decisão transitada em julgado ou proferida por órgão colegiado da Justiça Eleitoral, pelo prazo de 8 (oito) anos após a decisão, observando-se o procedimento previsto no art. 22;

${ }^{194} \S 9^{\circ}$ Lei complementar estabelecerá outros casos de inelegibilidade e os prazos de sua cessação, a fim de proteger a probidade administrativa, a moralidade para exercício de mandato considerada vida pregressa do candidato, e a normalidade e legitimidade das eleições contra a influência do poder econômico ou o abuso do exercício de função, cargo ou emprego na administração direta ou indireta. (Redação dada pela Emenda Constitucional de Revisão no 4, de 1994) 
Inicialmente, entenderam os Ministros, acompanhando o Ministro Relator Luiz Fux, que o direito de ser votado - ius honorum - não pode ser equiparado com direitos políticos lato sensu, de forma que a suspensão do exercício dessa prerrogativa não poderia ser considerada uma punição propriamente dita. Isso porque, segundo o raciocínio desenvolvido pela Corte, os cidadãos têm mera expectativa de direto à candidatura, a qual somente se concretiza quando há a comprovação do atendimento aos requisitos legais e constitucionais de elegibilidade.

Assim, a impossibilidade de ser votado, aferida no momento em que registrada a candidatura, não representaria a aplicação de uma sanção e não deveria observar a interpretação restritiva do princípio da presunção de inocência conferida aos ilícitos penais pelo próprio Supremo Tribunal Federal.

Nesse exato sentido, foi a seguinte manifestação do Ministro Luiz Fux, relator do processo:

\footnotetext{
"Questiona-se, então: é razoável a expectativa de candidatura de um indivíduo já condenado por decisão colegiada? A resposta há de ser negativa. Da exigência constitucional de moralidade para o exercício de mandatos eletivos (art. 14, $9^{\circ}$ ) se há de inferir que uma condenação prolatada em segunda instância ou por um colegiado no exercício da competência de foro por prerrogativa de função, a rejeição de contas públicas, a perda de cargo público ou o impedimento do exercício de profissão por violação de ver éticoprofissional excluirão a razoabilidade da expectativa. A rigor, há de se inverter a avaliação: é razoável entender que um indivíduo que se enquadre em tais hipóteses qualificadas não esteja, a priori, apto a exercer um mandato eletivo.
}

Como se percebe da manifestação acima, a premissa utilizada pelo Supremo Tribunal Federal para relativizar a aplicação do princípio da presunção de inocência funda-se na consideração de que o direito de ser votado é, na realidade, uma mera expectativa de direito, a ser concretizada mediante a análise do preenchimento de requisitos legais e constitucionais, a ser feita no momento do registro da candidatura.

E partindo dessa premissa, permite-se a conclusão de que, no caso concreto, deve-se conferir prevalência ao princípio da moralidade para o exercício de cargos públicos, previsto constitucionalmente pelo $\S 9^{\circ}$, do artigo 14 , da Constituição Federal, frente ao interesse privado de se eleger, o qual sequer pode ser considerado como um direito em si, mas meramente como uma expectativa de direito. 
Ademais, a ponderação realizada pelo Ministro Relator contrapôs de um lado da balança os direitos políticos passivos e, do outro, os princípios da moralidade e da própria democracia, tendo ele concluído que a balança certamente deveria pender para o segundo lado, tendo em vista não haver sequer lesão ao núcleo essencial dos direitos políticos, uma vez que, no caso em questão, tratava-se de mera relativização apenas da faceta passiva (de candidatar-se e de ser votado) desses direitos.

E ainda no tocante à ponderação, alegou o Ministro Relator a necessidade de se conferir validade à "ponderação efetuada pelo próprio legislador”, sendo hipótese de "interpretação da Constituição conforme a lei", inclusive pela colocação de conceitos indeterminados na diploma constitucional, como "vida pregressa".

Para tanto, o STF perquiriu a aplicabilidade e irradiação do princípio da presunção de inocência - positivado no inciso LVII, artigo $5^{\circ}$, da CF - ao processo eleitoral, revisitando o entendimento que havia sido firmado no julgamento da ADPF $\mathrm{n}^{\mathrm{o}}$ 144, em que o Ministro Relator, Celso de Mello, houvera afirmado a aplicação do referido princípio também ao processo eleitoral, como decorrência lógica da cláusula constitucional do Estado Democrático de Direito ${ }^{195}$.

Vale dizer que todo o juízo desenvolvido e o próprio resultado a que se chegou, decorreu também de uma análise de aplicabilidade e adequação da interpretação constitucional ao estado espiritual do povo brasileiro como então entendido pelo Supremo Tribunal Federal. Chegou a afirmar o Ministro Relator que "ou bem se realinha a interpretação da presunção de inocência, ao menos em termos de Direito Eleitoral, com o estado espiritual do povo brasileiro, ou se desacredita a Constituição”.

Na mesma toada, propôs o Eminente Ministro que o STF adotasse um constitucionalismo democrático, não se furtando a dar ouvidos aos anseios populares e às contestações e divergências surgidas no seio social em relação às suas decisões e, ao

\footnotetext{
195 A esse respeito, o Ministro Luiz Fux justificou o "overruling dos precedentes relativos à material da presunção de inocência vis-à-vis inelegibilidades" em decorrência de uma suposta "incongruência sistêmica ou social".
} 
mesmo tempo, não abandonando o seu papel contramajoritário de proteção aos direitos fundamentais.

A fundamentação do voto do Ministro Luiz Fux também passou pela consideração de que a cláusula constitucional da presunção de inocência não teria conteúdo principiológico, mas seria mera regra, de forma que a interpretação extensiva anteriormente conferida pela Corte ao referido dispositivo deveria ser novamente reduzida - por meio de uma denominada redução teleológica - para que sua interpretação pudesse reencontrar o seu sentido inicial e literal, de regra que não admite a mesma extensão interpretativa que os princípios ${ }^{196}$.

E em decorrência do raciocínio acima exposto, o próprio Ministro Relator já rechaçou a possibilidade de que sua interpretação pudesse configurar violação ao princípio da vedação do retrocesso, segundo o qual não pode uma norma legal posterior restringir o grau de concretização legislativa de um princípio fundamental alcançado anteriormente. E rechaçou essa possibilidade sob o fundamento de que não havia consenso básico social acerca da aplicabilidade da presunção de inocência às questões eleitorais e de que a restrição ora imposta pela Lei Complementar $n^{\circ} 135 / 10$ seria razoável e proporcional, diante da concretização do princípio da moralidade disposto no $\S 9^{\circ}$, do artigo 14, da CF.

Ainda como reforço de argumentação, o Ministro Relator afirmou que uma interpretação sistemática dos dispositivos constitucionais também levaria à conclusão da constitucionalidade das hipóteses de inelegibilidade previstas pela Lei Complementar $n^{\circ}$ 135/10, uma vez que o artigo 15 da Constituição Federal já prevê a perda dos direitos políticos (ativos e passivos) com a condenação definitiva em processo criminal ou por improbidade administrativa, de forma que a previsão do $\S 9^{\circ}$, do artigo 14 , da Constituição Federal, somente poderia ter efetividade e lógica caso se permitisse incluir, pela legislação complementar, hipóteses de perda ou suspensão dos referidos direitos por meio de decisões ainda não definitivas.

\footnotetext{
196 "Destarte, reconduzir a presunção de inocência aos efeitos próprios da condenação criminal se presta a impedir que se aniquile a teleologia do art. $14, \S 9^{\circ}$, da Carta Política, de modo que, sem danos à presunção de inocência, seja preservada a validade de norma cujo conteúdo, como acima visto, é adequado a um constitucionalismo democrático". Voto do Ministro Luiz Fux, Relator da ADI n 4.578
} 
Assim, votou o Ministro Relator, Luiz Fux, pela constitucionalidade dos dispositivos da Lei Complementar $n^{\circ} 135 / 10$ que adicionaram novas hipóteses de inelegibilidade ao ordenamento jurídico nacional.

Quanto à constitucionalidade do disposto nos incisos "e" e "l" da LC n 135/10 $0^{197}$, o Ministro Relator entendeu pela necessidade de se realizar uma interpretação conforme à Constituição, para que fosse possível do prazo de inelegibilidade de 8 (oito) anos posterior ao cumprimento da pena, o período de inelegibilidade já decorrido entre a condenação não definitiva e o respectivo trânsito em julgado, sob pena de, em alguns casos, subsistir pena extremamente longa e gravosa que pudesse ser equiparada à cassação de direitos políticos, vedada pela ordem constitucional.

Em seguida, o Ministro Joaquim Barbosa apresentou o seu voto-vista, em que acompanhou o Ministro Relator, acrescentando de interessante, em sua fundamentação, o que passamos a analisar.

O Ministro Joaquim Barbosa também confere especial relevância à mobilização social que deu origem à Lei Complementar $n^{\circ} 135 / 10$, afirmando que o movimento que subsistiu "[r]evela, sobretudo, um despertar de consciência a respeito do real significado da democracia e de um dos elementos constitutivos essenciais que é a representação política”.

E na mesma toada, afirma analisar o referido normativo sob a ótica da prevalência do interesse público e da valorização da moralidade e não para fíns de proteção de interesses individuais e privados, afirmando, no caso, dever haver nítida separação entre as esferas pública e privada e a conferência de prioridade à primeira.

Quanto à aplicabilidade das penas de inelegibilidade em períodos ainda posteriores ao cumprimento das eventuais penas definitivamente aplicadas - alíneas "e" e

\footnotetext{
197 e) os que forem condenados, em decisão transitada em julgado ou proferida por órgão judicial colegiado, desde a condenação até o transcurso do prazo de 8 (oito) anos após o cumprimento da pena, pelos crimes: (...)

1) os que forem condenados à suspensão dos direitos políticos, em decisão transitada em julgado ou proferida por órgão judicial colegiado, por ato doloso de improbidade administrativa que importe lesão ao patrimônio público e enriquecimento ilícito, desde a condenação ou o trânsito em julgado até o transcurso do prazo de 8 (oito) anos após o cumprimento da pena; (...)
} 
"l”, do inciso I, do artigo $1^{\circ}$, da LC n 135/10 -, o Ministro Joaquim Barbosa entendeu por bem julgar os dispositivos constitucionais.

Em seguida votou o Ministro Dias Toffoli, que inaugurou a divergência, iniciando sua argumentação pela análise do papel contramajoritário que deve exercer o STF e pela importância da faceta passiva do direito político - ius honorum - e da necessidade de se conferir prevalência a ela, sob pena de se restringir a ampla participação democrática no processo eleitoral.

Afirmou, ainda, que a prevalência do interesse público sobre o individual não poderia culminar com a anulação desse último e que a manutenção das expressões "ou proferida por órgão colegiado" e "ou proferida por órgão colegiado da Justiça Eleitoral" implicariam ofensa ao postulado da presunção de inocência e consequente violação de direito individual.

Concluiu que, em consequência mesmo dessa violação ao princípio da presunção de inocência, ao permitir que condenações ainda não definitivas operassem seus efeitos, haveria também transgressões ao postulado da segurança jurídica e também ao postulado da isonomia.

Reportou-se ao quanto restou definido pelo Supremo Tribunal Federal no julgamento do $\mathrm{HC} \mathrm{n}^{\circ}$ 84.078/MG, acima analisado, e argumentou que o próprio artigo 15, inciso III, da Carta Política, não permite que o preso provisório perca os seus direitos políticos, mas o advento da Lei Complementar passaria a permitir que a provisoriedade de uma sentença seria suficiente para tornar o indivíduo processado inelegível.

Argumentou, ainda, o Ministro Dias Toffoli, em seu voto divergente, que a previsão do artigo $26-C^{198}$ da Lei Complementar não seria suficiente para impedir

\footnotetext{
198 “Art. 26-C. O órgão colegiado do tribunal ao qual couber a apreciação do recurso contra as decisões colegiadas a que se referem as alíneas $d, e, h, j, l$ e $n$ do inciso I do art. $1^{\circ}$ poderá, em caráter cautelar, suspender a inelegibilidade sempre que existir plausibilidade da pretensão recursal e desde que a providência tenha sido expressamente requerida, sob pena de preclusão, por ocasião da interposição do recurso.

$\S 1^{\circ}$ Conferido efeito suspensivo, o julgamento do recurso terá prioridade sobre todos os demais, à exceção dos de mandado de segurança e de habeas corpus.

$\S 2^{\circ}$ Mantida a condenação de que derivou a inelegibilidade ou revogada a suspensão liminar mencionada no caput, serão desconstituídos o registro ou o diploma eventualmente concedidos ao recorrente.
} 
eventuais incongruências, mas pelo contrário, representaria incongruências ainda mais evidentes, uma vez que significaria regra de inversão do postulado da presunção de inocência, fragilização desse mesmo postulado, injustiça dos dispositivos legais e oportunidade de conferência de poderes excessivos aos juízes, que podem acabar sendo os responsáveis por definir aqueles que poderão ou não participar da disputa eleitoral, com base em critérios subjetivos que muitas vezes serão questionáveis.

Ressalte-se aqui, novamente, que estamos a nos cingir aos argumentos que tinham relação com o direito fundamental à presunção de inocência, sendo certo que muitos outros aspectos discutidos nos votos não foram e não serão detalhados aqui, por fugirem ao objeto da nossa pesquisa.

Quanto à aplicabilidade das penas de inelegibilidade em períodos ainda posteriores ao cumprimento das eventuais penas definitivamente aplicadas - alíneas "e" e "l", do inciso I, do artigo $1^{\circ}$, da LC n ${ }^{\circ} 135 / 10$-, o Ministro Dias Toffoli entendeu por bem acompanhar o Relator na interpretação conforme a Constituição sugerida.

Após a conclusão do voto do Ministro Dias Toffoli, que suscitou diversos debates entre os membros da Corte especialmente no tocante ao papel contramajoritário do Tribunal e à extensão e consequências da interpretação que o Ministro Relator propunha para o postulado da presunção de inocência, iniciou seu voto a Ministra Rosa Weber.

A Ministra Rosa Weber acompanhou o voto do Ministro Relator também forte na premissa de que a inelegibilidade não configura uma pena em si, muito menos de característica penal, sendo evidente, então, o objetivo da Lei Complementar no 135/10 de fazer valer os princípios da probidade e da moralidade cujo atendimento o $\S 9^{\circ}$ do artigo 14 da CF delegou à lei complementar definir ${ }^{199}$.

$\S 3^{\circ}$ A prática de atos manifestamente protelatórios por parte da defesa, ao longo da tramitação do recurso, acarretará a revogação do efeito suspensivo."

${ }^{199}$ Segundo a Ministra Rosa Weber afirmou em seu voto: "O escopo da inelegibilidade não é punir. A norma jurídica não tem no indivíduo seu destinatário primeiro - outro o foco - é sim a coletividade, buscando preservar a legitimidade das eleições, a autenticidade da soberania popular e, em última análise, a assegurar o processo de concretização do Estado Democrático de Direito". 
Também como o Relator, a Ministra Rosa Weber conferiu especial destaque à origem da Lei Complementar $n^{\circ}$ 135/10, relembrando que, desde o advento da Constituição da República de 1988, essa havia sido apenas a quarta lei de iniciativa popular aprovada, o que, diante dos requisitos restritivos de aprovação, conferia ao dispositivo legal relevância ímpar que deveria ser levada em consideração pelo STF.

E quanto ao papel contramajoritário do STF, afirmou a Ministra que o Tribunal não poderia ser insensível às aspirações da maioria, já que, "em uma democracia pluralista, todos compõem a sociedade aberta dos intérpretes da Constituição" e, por essa razão, as opiniões diversas devem ser sempre levadas em consideração para se construir uma interpretação consentânea com a unicidade da Constituição Federal.

Ainda no tocante à aplicação do princípio da presunção de inocência, a Ministra não negou a sua aplicabilidade ao âmbito eleitoral, mas simplesmente afirmou que a sua aplicabilidade naquele âmbito não pode ter a consequência de impedir que se estabeleçam medidas restritivas de direitos ainda sob o manto de decisões provisórias, uma vez que até mesmo o próprio processo penal admite restrições ao princípio da presunção de inocência como, por exemplo, a possibilidade de prisão provisória antes do julgamento definitivo do processo.

Por fim, no que diz respeito à aplicabilidade da sanção de inelegibilidade em período posterior ao cumprimento da pena - previsto nas alíneas "e" e "l", do inciso I, do artigo $1^{\circ}$, da $\operatorname{LC} n^{\circ} 135 / 10$-, a Ministra Rosa Weber entendeu ser constitucional a hipótese.

Vale dizer que, após seu voto, houve extensa discussão a respeito da matéria, em que os Ministros Dias Toffoli, Luiz Fux, Cezar Peluso e Gilmar Mendes ponderaram com a Ministra Rosa Weber que a consideração da constitucionalidade da aplicabilidade da penalidade após o cumprimento da pena acabaria por tornar o direito ao duplo grau de jurisdição uma opção funesta ao acusado, uma vez que ele teria a pena de inelegibilidade perpetuada por período extremamente longo, desproporcional e que poderia se assemelhar a uma cassação de seus direitos políticos. 
Encerrado esse debate, proferiu seu voto a Ministra Cármen Lúcia, acompanhando o Ministro Relator, mas conferindo ainda maior extensão a seu voto para considerar também constitucionais as previsões das alíneas " $\mathrm{e}$ " e "l" do inciso I, do artigo $1^{\circ}$, especificamente no ponto em que previam a aplicação da sanção por período que excedesse o cumprimento da pena ao final aplicada ${ }^{200}$.

Para a Ministra Cármen Lúcia, o princípio da presunção de inocência não seria aplicável à $L C n^{\circ} 135 / 10$, porque, a uma, a inelegibilidade não configuraria pena e, a duas, porque o postulado da presunção de inocência seria aplicável ao âmbito do Direito Penal, e não do Direito Eleitoral. Ademais, reforçou a Ministra que a Lei da Ficha Limpa teria complementado o sentido do $\S 9^{\circ}$ do artigo 14 , da CF, tornando-o plenamente eficaz e exigível, fazendo prevalecer os princípios de moralidade e probidade na seara eleitoral.

Após, votou o Ministro Ricardo Lewandowski, acompanhando também o voto do Ministro Relator e naquela oportunidade, houve o debate entre ele e o Ministro Celso de Mello acerca da ponderação de valores constitucionais, situando-se de um lado o direito político individual e, de outro, os direitos coletivos à probidade e à moralidade que, no entendimento do Ministro Lewandowski deviam-se sobrepor aos direitos individuais no caso concreto.

Em seguida, também acompanhando integralmente o voto do Ministro Joaquim Barbosa, pronunciou-se o Ministro Carlos Ayres Britto, focando no fato de que a $\operatorname{LC} n^{\circ} 135 / 10$ trazia complementação e eficácia ao dispositivo constitucional do $\S 9^{\circ}$, do artigo 14. Ressaltou, ainda, a ambição da LC de mudar a cultura nacional no aspecto da malversação da coisa pública.

Focou também o Ministro Ayres Britto a relevância da iniciativa popular que originou o projeto da $\operatorname{LC} n^{\circ} 135 / 10$, afirmando que a iniciativa popular fazia combinar a democracia representativa com o exercício da democracia direta e participativa, conferindo ao dispositivo legal dela oriundo um "tônus de legitimidade ainda maior, ainda mais denso".

200 Vale dizer que o posicionamento da Ministra Carmen Lúcia quanto a esse ponto específico foi confirmado apenas ao final dos debates, quando ela mudou o seu voto original no aspecto, que acompanhava inicialmente a interpretação conforme sugerida pelo Ministro Relator, Luiz Fux. 
Ademais, o Ministro trouxe dados que o permitiram realizar uma interpretação histórica do postulado da presunção de inocência na Constituição Federal de 1988, quando afirmou que, à época da Constituinte, foi proposta uma emenda em que a redação correspondente ao princípio aqui tratado não preveria a restrição ao âmbito do processo penal. Referida emenda, todavia, conforme informado pelo Ministro Ayres Britto, teria sido rejeitada pelos constituintes, que tiveram de fato a intenção de restringir o âmbito de aplicação do referido princípio ao processo penal.

Em seguida, foi a vez de o Ministro Gilmar Mendes proferir seu voto, que acompanhou a divergência inaugurada pelo Ministro Dias Toffoli. O Ministro destacou que a presunção de inocência é um postulado estabelecido constitucionalmente em favor das pessoas contra "abuso de poder e a prepotência do Estado" e por isso é garantia da mais ampla importância, devendo ser respeitada e irradiada para outros âmbitos que não apenas o penal.

Em seguida, contrapondo-se ao voto do relator, o Ministro Gilmar Mendes fez uma digressão acerca da democracia crítica, cuja concepção alerta para os riscos de uma “divinização do povo”, reforçando a necessidade de se assumir que também o povo é falível, assim como todo e qualquer cidadão. E na mesma toada, a respeito da relevância que os demais Ministros conferiram ao fato de a $\mathrm{LC}^{\circ}$ 135/10 ter origem em iniciativa popular, assim afirmou em seu voto:

\footnotetext{
“O argumento de que a lei é de iniciativa popular não tem peso suficiente para minimizar ou restringir o papel contramajoritário da Jurisdição Constitucional. É compreensível a ação das várias organizações sociais tendo em vista a repercussão que esse tema da 'ficha-limpa' tem na opinião pública. Sabemos que, para temas complexos em geral, há sempre uma solução simples e em geral errada. E para esse caso a população passa a acreditar que a solução para a improbidade administrativa, para as mazelas da vida política, é a Lei da Ficha Limpa. A partir daí há, na verdade, a tentativa de aprisionar, o que nos dificulta enormemente a missão nesta Corte, como em outros casos, porque acabamos tendo de nos pronunciar de forma contramajoritária, claro, tendo em vista a opinião pública, segundo as pesquisas manifestadas de opinião. Mas a missão desta Corte é aplicar a Constituição, ainda que contra a opinião majoritária. Esse é o ethos de uma Corte Constitucional. É fundamental que tenhamos essa visão."
}

Assim, no caso específico, manifestou o Ministro que não compete ao STF relativizar princípios constitucionais para atender aos anseios populares, ressaltando que 
as decisões contramajoritárias eventualmente tomadas pela Corte Suprema costumam originar movimentos de diálogo institucional, com debate intensos sobre as questões no meio social e político.

Ademais, focou o Ministro outro importante argumento até então não aventado por nenhum de seus outros pares, no sentido de que o regime democrático confere aos cidadãos, ao povo em geral, mecanismos outros de controle da moralidade no âmbito político, sendo o primeiro e mais elementar desses mecanismos o próprio voto.

Outro mecanismo de controle seria a própria nomeação dos candidatos feita pelos partidos políticos, os quais têm importância ímpar no processo democrático, conferida e assegurada constitucionalmente.

Ademais, reforçou o Ministro que o postulado da não culpabilidade (ou da inocência), ao contrário do quanto afirmado pelo Ministro Relator, não poderia ser considerado uma regra, mas sim efetivamente um princípio, tanto pela sua estrutura normativa, pela sua forma de aplicação e pelo seu caráter fundamental.

Refutou, ainda, o Ministro, os argumentos no sentido de que os julgamentos por órgãos colegiados se revestiriam de certeza e segurança jurídica, uma vez que se encerraria em segunda instância a possibilidade de análise fático-probatória.

Importante notar que também outra premissa constante nos votos proferidos pelo Ministro Relator e por aqueles que o acompanharam foi rechaçada pelo Ministro Gilmar Mendes. Para ele, a perda do direito político passivo (ius honorum), considerada de menor importância pelos Ministros filiados ao outro lado da controvérsia, foi vista por ele como uma "espécie de nulificação da própria cidadania, ainda que temporariamente", uma vez que os direitos políticos, em todas as suas facetas - passiva ou ativa - correspondem ao direito amplo de participação na vida política do país, sendo essenciais à "saúde da vida democrática".

Por fim, no tocante às alíneas "e" e "l" do inciso $\mathrm{I}$, do artigo $1^{\circ}$, da $\mathrm{LC} \mathrm{n}^{\mathrm{o}}$ 135/10, o Ministro acompanhou o voto do Ministro Relator no sentido de conferir aos dispositivos interpretação conforme, de acordo com o princípio da proporcionalidade. 
Em seguida, votou o Ministro Marco Aurélio que acompanhou o Ministro Relator no aspecto atinente à inexistência de violação ao princípio da presunção de inocência. Contudo, no tocante à parte do voto do Relator que deu interpretação conforme às alíneas "d" e "l” do artigo $1^{\circ}$, inciso $\mathrm{I}$, da LC n ${ }^{\circ}$ 135/10, travou discussão no Plenário no sentido de que aplicar outra interpretação a esses dispositivos corresponderia a realizar o trabalho do legislador positivo, vedado ao Supremo Tribunal Federal.

Votou, então o E. Ministro Celso de Mello, que acompanhou a divergência.

Por fim, o então Presidente do STF, Ministro Cezar Peluso, proferiu o seu voto no sentido da divergência inaugurada pelo Ministro Dias Toffoli no tocante à configuração de violação ao postulado da presunção de inocência.

Contudo, restou vencida a posição do Ministro Relator pela constitucionalidade da lei, vencidos os Ministros Dias Toffoli, Gilmar Mendes, Celso de Mello e Cezar Peluso.

\subsection{Conclusão parcial sobre a postura do Supremo Tribunal Federal nas hipóteses}

Ao contrário do que constatamos no bloco de direitos analisado no capítulo anterior, no que toca à presunção de inocência, o Supremo Tribunal Federal adotou dois posicionamentos distintos tanto no resultado quanto na fundamentação. No primeiro deles, que tratou da vedação da execução antecipada da pena em respeito ao princípio da presunção de inocência, definiu a Corte que a interpretação do princípio em questão deveria ser feita ainda que contrariamente aos anseios populares e até mesmo como uma defesa aos casuísmos comuns na interpretação do direito penal, servindo a Corte como protetora do núcleo essencial do princípio, tantas vezes esquecido pelas manifestações populares em situações específicas e pontuais de alta criminalidade.

Portanto, nesse primeiro caso, posicionou-se a Corte favoravelmente a restringir a influência das pressões populares, tomando posição passível de críticas até 
hoje. Essa postura contramajoritária explícita foi necessária, a nosso ver, para preservar garantias fundamentais duramente conquistadas e cuja importância muitas vezes não se reconhece quando não se está vivendo um regime político de concreta e sistemática ameaça a esses postulados.

É importante levar em consideração que os princípios e garantias constitucionais devem valer para todos os cidadãos - sejam eles criminosos ou não. A Constituição, como diploma supralegal legítimo, deve tutelar e preservar os direitos de todos, que devem ser igualitariamente vistos pelos aplicadores da lei, sob pena de se permitir a criação de regimes excludentes, totalmente incompatíveis com o Estado Democrático de Direito.

No caso em questão, para facilitar a concordância com a opinião externada pela Corte e contrária aos anseios populares, devemos nos focar nas possíveis injustiças que podem advir da não preservação do princípio em toda a sua expressão e não propriamente em casos isolados em que a pressão popular extrapola os limites das garantias fundamentais de qualquer cidadão.

E ainda que se argumente que, em alguns casos, a violação do direito fundamental de um indivíduo (como o direito à vida) só seria reparada com a violação do direito fundamental à presunção de inocência de outro indivíduo, o nosso posicionamento vai no sentido de que o Estado, como portador do dever de proteção dessas garantias, jamais deve chancelar posturas de afronta, nem tampouco caracterizar-se como o próprio violador de direitos fundamentais.

Também entendemos não haver procedência na divergência inaugurada pelo Ministro Menezes Direito, especialmente quando invocou os postulados de Dworkin e Alexy para defender que a execução antecipada da pena e as medidas cautelares de privação de liberdade deveriam ter a mesma interpretação, uma vez que regulariam situações fáticas idênticas e veiculariam princípios iguais, que deveriam ter a mesma aplicação em uma e em outra hipótese.

A inconsistência do raciocínio, ao nosso ver, reside na própria premissa adotada pelo Ministro, uma vez que os postulados de interpretação e aplicação dos 
princípios tanto em Dworkin quanto em Alexy preveem que eles podem sim levar a resultados diferentes quando as situações fáticas são diferentes, como é o caso. Isso porque as hipóteses de medidas cautelares de privação da liberdade são exatamente as exceções ao postulado geral e fundamental de que a presunção de inocência deve ser preservada até o trânsito em julgado da condenação.

Portanto, não há sequer que se falar, aqui, em vedação da proteção deficiente de um princípio, pois a garantia máxima da aplicação da presunção da inocência não ofende outros postulados ou garantias constitucionais, mormente porque existe a previsão excepcional das medidas cautelares de privação da liberdade, as quais são previstas exatamente com a finalidade de evitar proteção deficiente, não havendo argumentação plausível para justificar a execução antecipada da pena sem que ela viole por si só a presunção da não-culpabilidade e até, em última instância, a dignidade da pessoa humana.

E a postura adotada pela Corte naquela hipótese, a nosso ver, é a mais correta e a única que preserva em sua integralidade o sentido do princípio da presunção de inocência, de importância basilar para a concretude do Estado Democrático de Direito.

Assim, além de postura ativa do Supremo Tribunal Federal na interpretação adequada do princípio, com o exercício de sua função contramajoritária e com a promoção de justificação interna e externa absolutamente corretas, também houve, no caso concreto, mutação constitucional no tocante à extensão do princípio da presunção de inocência, tendo em vista que a jurisprudência consolidada do Tribunal pelos vinte anos que antecederam esse julgamento era no sentido de se permitir a execução antecipada da pena quando pendentes de julgamento recursos não dotados de efeito suspensivo.

Referida mutação constitucional, todavia, se deu apenas no tocante ao sentido atribuído ao princípio, cuja definição já não se encontra positivada na Constituição, sendo ele dotado de conteúdo genérico apto a ser definido pelo próprio intérprete. Portanto, tratou-se de hipótese de mutação constitucional porque houve modificação do sentido atribuído tradicionalmente ao princípio, sem que isso implicasse, 
contudo, qualquer modificação no texto da Constituição ou a atribuição de significados aparentemente incompatíveis com aqueles advindos do termo interpretado.

Vale dizer que, por ter havido superação de precedentes, o ônus argumentativo do Supremo no caso tornou-se ainda mais agravado. Todavia, ele foi devidamente superado pelos Ministros que -- por meio de aplicação de cânones de argumentação semântica, histórica, comparativa, teleológica, sistemática e genética, somados a análises empíricas --, conseguiram atribuir racionalidade aos resultados a que chegaram.

Entretanto, todo esse raciocínio que, na nossa visão, consolidou de forma plena e adequada o significado do princípio da presunção de inocência, cedeu espaço às pressões populares quando da interpretação da constitucionalidade da chamada Lei da Ficha Limpa, em julgamento cuja conclusão flexibilizou a extensão do princípio sob análise, permitindo restrições aos direitos políticos dos cidadãos condenados por colegiados, ainda que referida condenação fosse passível de revisão por meio de recurso.

As inconsistências do referido julgamento são muito claras após a constatação da relevância do princípio da presunção de inocência para a dignidade da pessoa humana e para o Estado Democrático de Direito.

Tanto é verdade que, a nosso ver, o Supremo Tribunal Federal precisou relativizar a extensão dos direitos políticos para permitir que, na ponderação de valores realizada no exame da constitucionalidade da norma em si, a balança pendesse contrariamente ao princípio da presunção de inocência.

Dessa forma, parece-nos que, não obstante tenha a Corte adotado a técnica de interpretação de direitos fundamentais que entendemos como a mais adequada, ela não foi aplicada com a racionalidade necessária, pois as premissas adotadas para sopesar os direitos em conflito acabaram por desnaturar um deles, o que prejudicou o processo e o resultado da ponderação.

Estamos nos referindo especificamente à diferenciação feita inicialmente pelo Ministro Relator entre direitos políticos passivos e ativos, dotando-se os últimos de 
uma maior relevância do que os primeiros. Para essa corrente que se sagrou majoritária no Supremo, o direito de votar seria postulado supremo da democracia, ao passo que o direito de ser votado seria mera expectativa de direito, de hierarquia inferior à sua faceta ativa.

E foi precisamente essa distorção do significado dos direitos políticos que permitiu o resultado a que chegou o Supremo, em que se conferiu prevalência aos princípios da moralidade e da democracia frente a direitos políticos despidos de sua real significação; portanto, enfraquecidos no conflito resolvido pela Corte.

Fica claro, da análise acima, que o resultado a que chegou a Corte, derivado do seu juízo de ponderação, não pode ser considerado racional porque falha no seu processo de justificação externa ao realizar distorções de premissas, prejudicando todo o desenvolvimento da técnica interpretativa.

Outra inconsistência que nos pareceu flagrante no julgamento foi a afirmação de que, na realização do juízo de ponderação, deveria ser conferida prevalência à própria ponderação feita pelo legislador ordinário quando da promulgação da lei.

Ora, a Corte Constitucional reafirmou em todos os julgados até agora analisados, e em muitos outros ao longo de sua história, a importância do seu papel contramajoritário na preservação da máxima eficácia dos direitos fundamentais quando confrontados com legislação que, a despeito de ter sido aprovada pela maioria do Congresso e de ter evidente apoio popular, confrontava com algum dispositivo constitucional. Todavia, nesse caso específico, preferiu o Supremo ignorar esse papel.

Não estamos aqui a afirmar que a Corte tem sempre que assumir função contramajoritária, mas apenas que no presente caso esse era o papel que ela deveria ter assumido, mesmo porque a argumentação utilizada por ela para reconhecer a constitucionalidade do dispositivo invocado precisou contar com a flexibilização do próprio conceito e extensão dos direitos políticos, tendo a ponderação em si representado inadequada e desproporcional restrição ao princípio da presunção de inocência, por meio da desnaturação dos direitos políticos fundamentais. 
Ou seja, a própria ponderação em si foi totalmente desconfigurada, pois ela é uma técnica que visa exatamente a evitar que os princípios fundamentais, quando em conflito, tenham seu conteúdo essencial atingido. E no caso concreto, o próprio Supremo feriu conteúdo essencial dos direitos políticos para chegar a um resultado de ponderação que, automaticamente, também prejudicou a plena eficácia do princípio da presunção de inocência.

E ao contrário do que argumentou o Ministro Relator, entendemos que a nova posição do Supremo referente à extensão do princípio da presunção de inocência no presente caso representou efetiva vedação à proibição de retrocesso, uma vez que reduziu o nível de concreção normativa a que tinha chegado o princípio tanto no julgamento do HC 84078 acima analisado, quando no julgamento da ADPF 144, que houvera decidido pela sua aplicabilidade também no âmbito eleitoral.

Vale dizer que, na linha oposta à defendida pelo Relator, a presunção de inocência não é regra, mas sim efetivo princípio cuja efetividade depende do significado que lhe é atribuído por seus intérpretes. Portanto, aqui se verifica mais uma tentativa de burlar as premissas para conseguir uma pretensa fundamentação do resultado pretendido, o qual se torna, consequentemente e desde logo, improcedente e carente de racionalidade.

Além disso, foi argumento frequente no julgamento a supremacia do interesse público sobre o interesse privado dos cidadãos de se candidatar para o exercício de cargos de públicos. Contudo, referido argumento é também frágil, uma vez que não se vislumbra, na atual configuração constitucional e social, uma nítida separação entre o público e o privado, sendo evidente que os direitos políticos, além de dimensão privada, têm nítida conformação pública, porque dizem respeito diretamente ao exercício da democracia e à plena configuração do Estado de Direito.

Vale dizer que todas essas manobras nas premissas interpretativas que permitiram a conclusão a que chegou o Ministro Relator foram justificadas, ao nosso ver, pela pressão política exercida por diversos setores da sociedade em favor da aprovação da Lei da Ficha Limpa. 
Foi referido instrumento legal uma das únicas quatro leis de iniciativa popular aprovadas na história da Constituição, o que aos olhos do Supremo deve ter-lhe conferido legitimidade adicional quando do enfrentamento de sua constitucionalidade.

Contudo, a participação popular na aprovação da lei não tem o condão de flexibilizar violação a princípios constitucionais, mormente quando revestidos de fundamentalidade indiscutível e de importância basilar para a consolidação do Estado Democrático de Direito.

A despeito de todas essas razões, o Supremo Tribunal Federal houve por bem alterar novamente a interpretação do princípio da presunção da inocência, ainda que tivesse buscado focar o conflito de interesses em jogo ao embate entre o direito político passivo e os princípios da moralidade e da democracia.

Observando ambos os julgados entendemos que, no primeiro, é possível verificar-se mutação constitucional, enquanto que no segundo caso, relativo à Ficha Limpa, é possível identificar não só mutação constitucional -- que entendemos ser inconstitucional na hipótese --, como também ativismo judicial.

Isso porque, conforme já amplamente debatido acima, o ativismo judicial caracteriza-se quando há a interpretação e aplicação de direitos pelo Supremo Tribunal Federal em atuação que exacerba os limites definidos pelo ordenamento jurídico.

À primeira vista, poderia o leitor afirmar que, no caso da Lei da Ficha Limpa, a Corte tão somente realizou os juízos de ponderação por nós mesmos defendidos e que, contudo, tendo chegado a resultado incompatível com o almejado por nós, levounos a atribuir a pecha de ativista à decisão.

De fato, se realmente tivesse ocorrido apenas isso não haveria que se falar em ativismo. Todavia, entendemos que o que ocorreu e foi objeto de análise pormenorizada acima, foi o mascaramento das premissas de fundamentação, com a distorção de sentido dos princípios em jogo, em articulada tentativa de fundamentação que buscou, no nosso sentir, simplesmente chancelar as expectativas populares no tocante à aprovação e constitucionalidade da Lei da Ficha Limpa. 
Mais ainda, defendemos que agindo dessa forma -- privilegiando os anseios populares em detrimento dos princípios constitucionais fundamentais e utilizando-se, para tanto, de premissas equivocadas e distorcidas sobre os fatos e princípios em jogo --, certamente há que se considerar que o Supremo Tribunal Federal extrapolou os limites de atuação que lhe impõe a própria Constituição, acabando por representar a sua violação, ao invés de sua guarda.

E essa postura ativista com ênfase no atendimento a pressões e anseios populares, vale dizer, implicou também, a nosso ver, mutação constitucional inconstitucional, ao passo em que modificou o sentido já consolidado e a extensão de eficácia do princípio da presunção de inocência.

E essa mutação se deu tanto em relação aos sentidos definidos no julgamento do HC 84078 quanto àquele consolidado no julgamento da ADPF 144, pois não só o Supremo Tribunal Federal permitiu que decisão ainda não transitada em julgado fosse passível de acarretar restrição ao direito político fundamental do cidadão -- o que não pode ser outra coisa que não uma sanção --, como acabou por reformar entendimento no sentido de que o princípio em questão não seria aplicável ao âmbito eleitoral.

E precisamente por ter representado retrocesso aos sentidos e à extensão de efeitos já anteriormente consolidados pelo STF em relação ao princípio da presunção da inocência, além de não se encontrar qualquer justificativa adequada e proporcional que justificasse a restrição imposta, há que se reconhecer que a mutação constitucional empreendida no segundo caso foi inconstitucional, uma vez que restringiu, sem qualquer justificativa plausível, o sentido e a extensão do princípio da presunção de inocência, tão caro à democracia e ao Estado de Direito. 


\section{A POSTURA DO SUPREMO TRIBUNAL FEDERAL QUANTO À EFETIVIDADE DOS DIREITOS SOCIAIS}

O próximo grupo de direitos fundamentais que será objeto de nossa análise é o dos direitos sociais.

Pelas peculiaridades de que se revestem esses direitos, sua análise se torna ainda mais interessante, considerando a importância discutível de sua positivação no texto constitucional e a dificuldade de se determinar a sua eficácia, tendo em vista que a concretização de tais direitos depende de políticas públicas, de viabilidade orçamentária e de outros fatores políticos que não só a vontade de fazer valer o direito em si.

Como direitos de segunda geração (ou dimensão), os direitos sociais passaram a ser positivados pelos ordenamentos quando se percebeu que apenas o dever de abstenção do Estado de interferir na autonomia privada e na esfera de liberdade dos indivíduos não era suficiente para garantir uma vida digna, fazendo surgir a necessidade de se prever deveres de proteção por parte do Estado que, assegurados, permitissem a correta fruição dos direitos individuais de primeira geração, conquistados principalmente com as Revoluções Francesa e Norte-Americana.

E esses direitos sociais compreendem, pelo próprio texto do artigo $6^{\circ}$ da Constituição Federal, “a educação, a saúde, a alimentação, o trabalho, a moradia, o lazer, a segurança, a previdência social, a proteção à maternidade e à infância, a assistência aos desamparados, na forma desta Constituição”.

Como se observa do próprio rol de direitos sociais constitucionalmente previstos, a apreciação de questões concretas que envolvam a sua efetividade implica análise de questões outras que não apenas a pura e simples determinação de vigência desses direitos, mormente porque são eles prestações que dependem de ação estatal.

E a ação estatal, em seu sentido amplo, depende de diversos outros fatores

que não se restringem apenas às disponibilidades orçamentárias, mas também às conjunturas políticas, ao estabelecimento e definição discricionários de prioridade de 
atuação pelos entes estatais e tantos outros fatores que, muitas vezes, o Poder Judiciário não tem a condição de sopesar na decisão de um caso concreto específico.

É evidente, portanto, que para apreciar e decidir um caso que implique efetividade dos direitos sociais, o Supremo Tribunal Federal, além de analisar se houve a violação no caso concreto, precisa considerar uma série de outros elementos na tomada de sua decisões, os quais muitas vezes sequer são de seu específico conhecimento, o que pode acabar eivando de ineficácia um futuro provimento jurisdicional e desacreditando a jurisdição constitucional e a própria Corte Suprema.

Exemplos concretos do que estamos falando são atualmente fartos, principalmente quando o Poder Judiciário determina, no julgamento de um caso concreto, a realização de uma medida que o Poder Público simplesmente não possui condições para atender.

É o caso, por exemplo, dos familiares de um paciente que necessita ser internado em leito de UTI de um hospital público e que apela ao Poder Judiciário, conseguindo uma determinação judicial para que seja imediatamente internado.

O hospital, contudo, não o internou porque não existiam vagas disponíveis naquela UTI e os médicos não podem assumir a responsabilidade de escolher retirar um paciente para ocupar a sua vaga com outro, por conta de uma determinação judicial tomada com base apenas na alegação individual de um sujeito, sem considerar a situação concreta do hospital, dos demais pacientes, do orçamento da Secretaria de Saúde, da definição de prioridades e metas de gastos e tantos outros fatores que acabam culminando com a negativa de eficácia do direito social à saúde de um, para garantir a mesma eficácia para outro, ou outros, às vezes até de outras formas e por meio da aplicação de novas e diferentes políticas públicas.

Da mesma forma, o Poder Judiciário não pode, quando confrontado com uma situação concreta de inegável violação ou negativa de eficácia de um direito social de base constitucional, simplesmente negar-se a conferir a prestação jurisdicional cabível no caso concreto, sob pena de total descrédito à jurisdição. 
Ao mesmo tempo, a concessão de um provimento jurisdicional que revelase absolutamente inexequível, na prática, pode acabar acarretando descrédito à própria função jurisdicional, dada a ineficácia de seus provimentos.

Feitas essas considerações iniciais, verificaremos como o Supremo Tribunal Federal tem agido quando confrontado com questões de efetividade dos direitos fundamentais sociais e como todos esses fatores têm sido contrabalanceados em suas decisões de casos concretos, a fim de que possamos concluir como tem sido a postura da Suprema Corte também no caso de promoção da eficácia desses já mencionados direitos sociais.

\subsection{Do direito à educação}

Inicialmente, vamos analisar o Agravo Regimental no Recurso Extraordinário com Agravo $\mathrm{n}^{\mathrm{0}}$ 639.337/ $\mathrm{DF}^{201}$, de que foi Relator o Ministro Celso de Mello, julgado pela Segunda Turma em agosto de $2011^{202}$.

Tratava-se de recurso interposto pelo município de São Paulo contra decisão que obrigava a Municipalidade a efetuar a matrícula de toda e qualquer criança em idade de até 5 (cinco) anos, em creche próxima a sua residência ou ao local de trabalho dos pais, sob pena do pagamento de multa pelo Estado por cada criança a quem fosse negada a matrícula respectiva.

A controvérsia toda girou em torno da eficácia do inciso IV do artigo 208 da Constituição Federal, o qual prevê que uma das formas de se efetivar o dever do Estado com a educação é garantir educação infantil, em creche e pré-escola, às crianças de até 5 (cinco) anos de idade ${ }^{203}$.

\footnotetext{
${ }^{201}$ Esse tema já foi analisado pelo Supremo Tribunal Federal também em outros casos, dentre os quais podemos citar como exemplo: AI 455.802/SP, Rel. Min. Marco Aurélio; AI 475.571, Rel. Min. Marco Aurélio; RE 401.673/SP, Rel. Min. Marco Aurélio; RE 411.518-AgR/SP, Rel. Min. Marco Aurélio; RE 410.715-AgR/SP, Rel. Min. Celso de Mello; RE 595.595-SgR/SC, Rel. Min. Eros Grau; e RE 436.996/SP, Rel. Min. Celso de Mello.

202 ARE 639337 AgR, Relator(a): Min. CELSO DE MELLO, Segunda Turma, julgado em 23/08/2011, DJe-177 DIVULG 14-09-2011 PUBLIC 15-09-2011 EMENT VOL-02587-01 PP-00125

${ }^{203}$ Art. 208. O dever do Estado com a educação será efetivado mediante a garantia de:(...)

IV - educação infantil, em creche e pré-escola, às crianças até 5 (cinco) anos de idade;
} 
O início do voto do Ministro Relator, que foi acompanhado por todos os demais integrantes da Turma na íntegra, diz respeito desde seu início à possibilidade de intervenção judicial em matéria de políticas públicas, como no caso dos autos.

Para o Relator, o caso específico poderia ser considerado como hipótese de política pública constitucionalmente definida, de forma que qualquer omissão governamental a respeito da sua implementação deveria ser considerada como omissão estatal injustificável apta a frustrar, por inércia, a prestação imposta pela Constituição, deixando de concretizar, por consequência, o direito social a ela correlato ${ }^{204}$.

Assim, tratando-se de hipótese de eficácia ou negativa de eficácia a mandamentos constitucionais, teria que ser diminuído o espaço de discricionariedade inicialmente conferido aos entes políticos, uma vez que juízos de conveniência e oportunidade não podem ser considerados aptos a restringir a eficácia de um direito fundamental ${ }^{205}$. E nessas hipóteses, seria possível ao Poder Judiciário que determinasse a implantação de políticas públicas já definidas na Constituição, ainda que essa possibilidade fosse excepcional.

Além do mais, pontuou o Ministro Celso de Mello tratar-se de hipótese de implementação de política pública, condicionada por fatores reais como o de disponibilidade orçamentária, escassez de recursos públicos e juízo de ponderação entre valores de igual importância que acabam por entrar em conflito na impossibilidade de se concretizar ambos, por insuficiência de recursos.

\footnotetext{
${ }^{204}$ Assim argumentou o Relator nesse ponto: "Tenho para mim, desse modo, prestem tal contexto, que os Municípios (à semelhança das demais entidades políticas) não poderão demitir-se do mandato constitucional, juridicamente vinculante, que lhes foi outorgado pelo art. 208 da Constituição, e que representa fator de limitação da discricionariedade político-administrativa do Poder Público, cujas opções, tratando-se de proteção à criança e ao adolescente, não podem ser exercidas de modo a comprometer, com apoio em juízo de simples conveniência ou de mera oportunidade, a eficácia desse direito básico de índole social."

${ }^{205}$ Nesse sentido é o seguinte item da ementa, por si só bastante esclarecedor: "a inércia estatal em adimplir as imposições constitucionais traduz inaceitável gesto de desprezo pela autoridade da Constituição e configura, por isso mesmo, comportamento que deve ser evitado. É que nada se revela mais nocivo, perigoso e ilegítimo do que elaborar uma Constituição, sema vontade de fazê-la cumprir integralmente, ou, então, de apenas executá-la com o propósito subalterno de torna-la aplicável somente nos pontos que se mostrarem ajustados à conveniência e aos desígnios dos governantes, em detrimento dos interesses maiores dos cidadãos."
} 
Não obstante esses aspectos práticos e de decisão eminentemente política, o Ministro ponderou que o provimento jurisdicional no caso concreto não poderia representar intrusão na esfera de outros Poderes, por se tratar de jurisprudência afirmativa autorizada, uma vez que buscava consagrar a primazia da Constituição em face de omissões injustificadas do Poder Público ${ }^{206}$.

E para evitar que "escolhas trágicas" sejam tomadas nessa ponderação de valores, deve o intérprete sempre guiar-se pelo critério de "intangibilidade do mínimo existencial", que é o desdobramento do princípio da dignidade da pessoa humana em todas as suas vertentes.

Vale dizer, nesse aspecto, que não se poderá sobrepor a cláusula da reserva do possível ao mínimo existencial, devendo sempre esse último prevalecer sobre o primeiro, inclusive nas hipóteses em que surja a necessidade de ponderação de valores constitucionais para a definição prioritária de uma dentre muitas políticas públicas necessárias e possíveis.

Todavia, ponderou o Relator que, nas hipóteses em que o Poder Público comprove irrefutavelmente que não possui condições financeiras para suprir a omissão em que incorre e que o Poder Judiciário busca reparar, deverá então ser levado em consideração esse ponto para que não se exija do Poder Público, nessa hipótese específica, a efetivação imediata daquele comando constitucional.

Por fim, invocando o princípio da proibição do retrocesso, o Ministro argumentou que, uma vez definido o direito social a que deve obediência o Estado, esse jamais poderá tomar qualquer postura que restrinja esse direito já reconhecido, devendo ainda tomar providências adicionais de efetivação e proteção dos referidos direitos.

\footnotetext{
206 Pontuou o Ministro textualmente: “É que, dentre as inúmeras causas que justificam esse comportamento afirmativo do Poder judiciário (de que resulta uma positiva criação jurisprudencial do direito), inclui-se a necessidade de fazer prevalecer a primazia da Constituição da República, muitas vezes transgredida e desrespeitada por pura, simples e conveniente omissão dos poderes públicos. Na realidade, o Supremo Tribunal Federal, ao suprir as omissões inconstitucionais dos órgãos estatais e ao adotar medidas que objetivem restaurar a Constituição violada pela inércia dos Poderes do Estado, nada mais faz senão cumprir a sua missão institucional e demonstrar, com esse gesto, o respeito incondicional que tem pela autoridade da Lei Fundamental da República."
} 
O Relator ainda mencionou que a necessidade de provimento jurisdicional positivo nas hipóteses de omissão inconstitucional por parte do Poder Público -- fosse essa omissão total ou parcial, como no caso concreto -- era inquestionável diante da constatação de que a omissão estatal pode configurar um processo informal de mudança da Constituição. E sendo um processo derivado de uma atitude de desrespeito a mandamento constitucional, certamente que o ato deveria ser combatido antes que lograsse a mudança específica, fazendo de vez inválida a norma inserta no texto constitucional.

Explicou que a interpretação das normas programáticas precisa conduzirse de forma a não torna-las meras promessas inconsequentes e ineficazes. Dessa forma, as normas programáticas devem ser consideradas como normas vinculantes, cujas disposições obrigam o Poder Público a tomar as medidas concretas necessárias a sua completa efetividade.

E foi com base nesses argumentos que o Ministro Celso de Mello negou provimento ao recurso interposto pelo Município de São Paulo, reafirmando o seu dever de tomar todas as medidas possíveis para tornar plenamente eficaz a norma do artigo 208, inciso IV, da Constituição Federal, considerando como auto-executável e absolutamente vinculante referido dispositivo constitucional, inclusive determinando a aplicação de multa ao ente estatal no caso de descumprimento da regra em questão.

\subsection{Do direito à saúde}

O precedente escolhido para representar, na nossa análise, o posicionamento do Supremo Tribunal Federal em relação ao direito social à saúde foi o Recurso Extraordinário $\mathrm{n}^{\mathrm{o}} 271.286 / \mathrm{RS}^{207}$, também de relatoria do Ministro Celso de Mello ${ }^{208}$.

\footnotetext{
${ }^{207}$ RE 271286 AgR, Relator(a): Min. CELSO DE MELLO, Segunda Turma, julgado em 12/09/2000, DJ 24-11-2000 PP-00101 EMENT VOL-02013-07 PP-01409

${ }^{208}$ Também aqui outros precedentes que analisaram a mesma matéria podem ser apontados, tais como: RE 242.859/RS, Rel. Min. Ilmar Galvão; RE 232.335/RS, Rel. Min. Celso de Mello; RE 273.834/RS, Rel. Min. Celso de Mello.
} 
Apesar de ser um julgado relativamente antigo, ele é representativo da controvérsia por abordar diversas facetas da questão da eficácia do direito social à saúde e portanto será ele o objeto da nossa análise.

Nesse Recurso Extraordinário, a Segunda Turma do STF analisou o dever estatal de fornecer medicamentos a pessoa desprovida de recursos financeiros, portadora do vírus HIV, examinando especificamente a eficácia do artigo $5^{\circ}$, caput ${ }^{209}$, e do artigo 196 da Constituição Federal.

Também nessa ocasião o Ministro Celso de Mello posicionou-se no sentido de que o Município de Porto Alegre teria que assumir a obrigação, juntamente com o Estado, de fornecer os medicamentos de forma gratuita aos portadores do vírus HIV, ainda que os gastos correspondentes não estivessem previstos na lei orçamentária anual.

Isso porque, conforme aduziu o Relator, o artigo 196 da Constituição assegura ser dever de todos a proteção à sua saúde por parte do Poder Público e, diante da imposição desse valor pela própria Lei Fundamental, o Poder Judiciário deveria sempre se pronunciar de forma a privilegiar a eficácia desse direito, principalmente quando confrontado com um interesse financeiro alegado pelo Poder Público, o qual possui certamente muito menos relevância nesse originário juízo de ponderação.

Também aqui aduziu o Ministro Celso de Mello a impossibilidade de se permitir que o Estado se esquivasse de cumprir o mandamento de fornecimento gratuito de medicamentos, indiretamente originado dos dispositivos constitucionais constantes da cabeça do artigo $5^{\circ}$ e do artigo 196 , sob o argumento de que referidas normas seriam meramente programáticas.

\footnotetext{
${ }^{209}$ Art. $5^{\circ}$ Todos são iguais perante a lei, sem distinção de qualquer natureza, garantindo-se aos brasileiros e aos estrangeiros residentes no País a inviolabilidade do direito à vida, à liberdade, à igualdade, à segurança e à propriedade, nos termos seguintes:

(...)

Art. 196. A saúde é direito de todos e dever do Estado, garantido mediante políticas sociais e econômicas que visem à redução do risco de doença e de outros agravos e ao acesso universal e igualitário às ações e serviços para sua promoção, proteção e recuperação.
} 
Conforme já havia assinalado no julgado sobre a educação, o Relator reforçou que as normas programáticas representam, sim, obrigações ao Estado, não podendo ser invocadas para justificar possível e eventual descumprimento de preceitos e direitos fundamentais ${ }^{210}$.

Dessa forma, não basta que o Estado apenas positive um direito -- apesar de ser essa positivação um estágio importante para o reconhecimento desse direito. Uma vez positivado, todas as medidas possíveis devem ser adotadas para implementá-lo e promover sua eficácia.

\subsection{Conclusão parcial sobre a postura do Supremo Tribunal Federal nas hipóteses}

Como se percebe, a postura do Supremo relativamente aos direitos sociais afigura-se também ativa, promovendo a Corte a efetividade desses direitos de segunda geração quando instada a se manifestar a respeito de sua eficácia.

É importante observar a relevante consideração exposta nos votos analisados de que a atuação do Judiciário deve se dar também nessas hipóteses, sob pena de se chancelar um outro processo de mutação constitucional indesejada, derivado da reiterada omissão do Poder Público em concretizar os direitos sociais.

A despeito de se configurarem como normas programáticas, os direitos sociais devem ser considerados como vinculantes ao Poder Público, sob pena de se tornarem ineficazes e de acabarem por desprestigiar a força normativa da Constituição.

A ponderação entre um direito social e a alegação de insuficiência econômica do ente público certamente só poderia pender em favor da eficácia do direito social, pois eles traduzem preceitos de importância extrema e intimamente ligados à preservação da própria dignidade da pessoa humana.

\footnotetext{
${ }^{210}$ Nesse sentido: "Nesse contexto, incide, sobre o Poder Público, a gravíssima obrigação de tornar efetivas as prestações de saúde, incumbindo-lhe promover, em favor das pessoas e das comunidades, medidas - preventivas e de recuperação -, que, fundadas em políticas públicas idôneas, tenham por finalidade viabilizar e dar concreção ao que prescreve, em seu art. 196, a Constituição da República."
} 
É evidente, nos casos em questão, que ao preservar o direito fundamental em jogo e determinar o seu cumprimento, o Poder Judiciário passa por cima de considerações de conveniência e oportunidade feitas pelo Poder Público quando de seu planejamento orçamentário e de execução e implementação de políticas públicas.

Contudo, as balizas de atuação do Poder Judiciário definidas pela própria Constituição Federal não abrangem a realização de juízos de conveniência e oportunidade na implementação e definição de políticas públicas, restringindo-se a atribuir a esse Poder a função de guardião da Constituição e dos princípios fundamentais.

Assim, o Poder Judiciário deverá agir dentro das possibilidades de atuação conferidas pelo ordenamento e, dentro dessas possibilidades, deverá exercer a sua função da forma mais eficiente possível, promovendo na maior extensão os direitos fundamentais cujos descumprimentos lhe são submetidos a apreciação.

Levando em consideração que o objeto do presente trabalho é analisar a postura do Supremo Tribunal Federal na efetividade dos direitos fundamentais, temos que, apesar de os direitos sociais serem de difícil cumprimento imediato, eles devem ser preservados no máximo de sua extensão pelo Judiciário, que não pode se furtar de apreciar e decidir os casos concretos apresentados para julgamento.

Há quem diga que a posição do Supremo Tribunal Federal e dos demais tribunais pátrios quando da expedição de decisões da natureza daquelas ora analisadas, configura ativismo judicial indevido, pois representa ingerência do Judiciário na esfera de atuação dos poderes Executivo e Legislativo, mormente no que diz respeito à definição e implementação das políticas públicas decorrentes da concretização desses direitos sociais.

Ocorre que, a nosso ver, essa crítica não só está equivocada, como está também direcionada às esferas erradas do Poder Público. Isso porque, ao determinar a plena eficácia de um direito social, o Judiciário não extrapola os limites de atuação que lhe foram conferidos pela Constituição, mas apenas atua dentro das atribuições que the são direcionadas, proferindo decisões que atendem à expectativa social depositada no Judiciário em virtude da conformação legislativa de sua atuação. 
Dessa forma, para que a decisão judicial seja considerada adequada, racional e proporcional, não importa se ela tenha ou não levado em consideração as possibilidades orçamentárias, as definições de prioridade pelo Poder Público ou outras questões políticas de mesma hierarquia, pois a análise dessas questões não é atribuição do Poder Judiciário que, se o fizesse, aí sim estaria se imiscuindo indevidamente nas esferas de atuação dos demais poderes públicos.

Não se está a afirmar aqui que o Judiciário não tenha a levar em consideração as razões expostas pelo Poder Público para justificar sua omissão. Claramente, ele deverá levá-las em conta, como o faz com todos os argumentos contrapostos em qualquer ação que julga.

Todavia, quando confrontado com o desrespeito e até a negativa de vigência a um direito social fundamental, não há outra escolha possível ao Poder Judiciário que não optar pela atribuição de eficácia máxima ao princípio fundamental em jogo, mormente quando a alegação contraposta for a de ausência de recursos.

Vale dizer que referida alegação, muito comum em casos dessa natureza pelo Poder Público, é de difícil assimilação, pois a definição de prioridades de governo não deve causar tanta dificuldade quando se colocam em lados diversos da balança as verbas frequentemente gastas com publicidade governamental, por exemplo, em detrimento de valores como saúde e educação.

E nem se afirme que a atitude do Poder Judiciário pode se tornar inócua, prejudicando a força normativa da Constituição se o Poder Público não dispuser de verbas ou possibilidades fáticas de satisfazer a prestação jurisdicional imposta.

Isso porque, assim como são programáticas as normas de direitos sociais, também as decisões judiciais que as impõem podem ter a mesma característica. Com isso queremos dizer que, caso não haja possibilidade de cumprimento imediato do mandamento judicial, isso não significará um descrédito ao Judiciário e nem mesmo à Constituição, pois mesmo que não haja possibilidade de cumprimento imediato, fica consignada a indevida omissão do Poder Público cuja superação será reforçada por 
mandamento judicial que pode acarretar sanções diversas à Administração e a seus prepostos.

Dessa conclusão decorre exatamente o raciocínio contrário. Ou seja, havendo negativa por parte do Poder Judiciário de determinar o imediato cumprimento do direito social fundamental em jogo, aí sim estaria desacreditada a Constituição e o próprio Poder Judiciário. Isso porque as disposições constitucionais seriam vistas como desprovidas de força executória e, portanto, como simples programas e intenções sem qualquer vinculação ou obrigatoriedade de cumprimento, ao passo que o Judiciário seria visto como um poder inócuo, incapaz de agir de forma independente dos demais, o que causaria até mesmo um desequilíbrio nas forças e poderes constituídos.

De todo o exposto, os presentes casos nos auxiliam a concluir que, em relação aos direitos fundamentais sociais, a posição do Supremo Tribunal Federal também é ativa, ainda que não possa ser considerada ativista.

Do mesmo modo, não se pode verificar mutação constitucional nas interpretações conferidas pela Corte aos direitos sociais em jogo, mesmo porque, apesar de serem passíveis de concretização por normas e regulamentos específicos, referidos direitos possuem consequências altamente previsíveis, não se configurando as interpretações conferidas nos casos tomados como exemplo, modificações no sentido constitucional dos termos.

Todavia, caso o Poder Judiciário se negasse a apreciar a matéria ou se negasse a conferir efetividade máxima aos direitos sociais em foco, aí sim poder-se-ia configurar mutação constitucional. E essa mutação seria absolutamente inconstitucional, pois representaria, ainda que informalmente, a negativa de vigência e eficácia de dispositivos que foram colocados no texto constitucional para servirem não de diretriz incerta e genérica para o Poder Público, mas sim como guias de atuação indiscutíveis e vinculantes em todos os seus sentidos.

Portanto, a crítica geralmente dirigida ao Poder Judiciário quando atua de forma ativa na proteção dos direitos sociais deveria, na verdade, se voltar aos Poderes Legislativo e Executivo, pois são eles os responsáveis por fazer valer a proteção aos 
direitos sociais. E o Judiciário só é chamado a atuar porque eles não realizaram de forma adequada as atribuições que o texto constitucional lhes impõe.

Sendo assim, é evidente que não se pode culpar o Judiciário por se imiscuir, teoricamente, em funções que seriam privativas dos outros poderes, quando na realidade ele apenas está agindo dentro do seu escopo de atuação e de acordo com os limites constitucionalmente definidos, enquanto os outros Poderes estão incorrendo em omissões inconstitucionais que representam violação a direitos constitucionalmente previstos, as quais devem ser rechaçadas pelo poder competente, quando provocado, como foi feito nos casos acima analisados e é feito em tantos outros casos semelhantes no Judiciário nacional.

Em suma, todas as críticas dirigidas ao Poder Judiciário nessa atuação estão indevidamente direcionadas a ele, já que deveriam ter como alvo a inércia dos poderes Legislativo e Executivo em proporcionar as condições para a plena realização dos direitos sociais, mormente na definição de prioridades de gastos e implementação e definição de políticas públicas. 


\section{A POSTURA DO SUPREMO TRIBUNAL FEDERAL QUANTO À EFETIVIDADE DO DIREITO À VIDA}

\subsection{O julgamento sobre pesquisas com células-tronco}

No presente e último tópico, analisaremos a discussão que se instalou no Supremo Tribunal Federal sobre os limites do direito à vida, as circunstâncias que o caracterizam e a concretude da proteção a ele oferecida, principalmente por meio da análise da ADI 3.510/DF, em que se discutiu a constitucionalidade da Lei de Biossegurança, mais especificamente no tocante à autorização de realização de pesquisas científicas para fins terapêuticos com células-tronco.

A ADI em questão foi proposta pelo Procurador-Geral da República em face do artigo $5^{\circ}$ da Lei $n^{\circ} 11.105 / 05^{211}$, a qual autoriza a realização de pesquisas científicas com células-tronco embrionárias, sob o fundamento de que o artigo em questão contrariaria a inviolabilidade do direito à vida, tendo em vista que o embrião humano é vida humana, de modo a prejudicar o maior fundamento do Estado Democrático de Direito, fruto inclusive do princípio da dignidade da pessoa humana.

Mencionando que a Constituição silencia sobre o momento em que teria início a vida humana, o Ministro Relator reporta-se à análise do tema no nível infraconstitucional e conclui que, de acordo com o Código Civil, o Brasil adota a teoria natalista, segundo a qual a personalidade é adquirida apenas com o nascimento vivo, de forma que, quando a Constituição faz referencia à dignidade da pessoa humana e aos direitos que a pessoa possui, ela está a fazer referência ao nativivo.

\footnotetext{
${ }^{211}$ Art. $5^{\circ}$ É permitida, para fins de pesquisa e terapia, a utilização de células-tronco embrionárias obtidas de embriões humanos produzidos por fertilização in vitro e não utilizados no respectivo procedimento, atendidas as seguintes condições:

I - sejam embriões inviáveis; ou

II - sejam embriões congelados há 3 (três) anos ou mais, na data da publicação desta Lei, ou que, já congelados na data da publicação desta Lei, depois de completarem 3 (três) anos, contados a partir da data de congelamento.

$\S 1^{\circ}$ Em qualquer caso, é necessário o consentimento dos genitores.

$\S 2^{\circ}$ Instituições de pesquisa e serviços de saúde que realizem pesquisa ou terapia com células-tronco embrionárias humanas deverão submeter seus projetos à apreciação e aprovação dos respectivos comitês de ética em pesquisa.

$\S 3^{\circ}$ É vedada a comercialização do material biológico a que se refere este artigo e sua prática implica o crime tipificado no art. 15 da Lei no 9.434, de 4 de fevereiro de 1997.
} 
Assim, a cada estágio de vida do ser humano o Direito confere proteções diferentes, cujo grau de efetividade vai aumentando ao longo do tempo.

Contudo, pontuou também o Ministro que o Direito Civil confere proteção já ao nascituro, que vem a ser aquele embrião/feto que tenha a aptidão para avençar na trilha do nascimento. Discorreu, ainda, que essa proteção decorre da supremacia do princípio da dignidade da pessoa humana, que permite o transbordamento de seu significado para além da concepção de personalidade.

Lembrou que a proteção do nascituro tem também reflexos em outras normas legais, como aquela da Lei $n^{0}$ 9.434/97, que veda a doação de tecidos, órgãos ou partes do corpo vivo do feto, bem como os dispositivos da Lei Penal que criminalizam o aborto. Ressaltou, porém, que em ambos os casos o feto encontra-se no interior do corpo feminino, possuindo aquele diferencial que o caracteriza como nascituro -- a potencialidade de vida.

Conclui, então, nesse aspecto inicial de sua análise, que pelas normas legais e também de acordo com os estudos científicos sobre a matéria, não se pode afirmar existir uma pessoa humana embrionária, mas apenas um embrião de pessoa humana, diferenciando-se as fases de seu desenvolvimento e, consequentemente, os atributos e direitos atribuídos a cada uma dessas fases ${ }^{212}$.

Fixadas essas premissas, o Relator passa à análise do dispositivo legal questionado, pontuando desde o início que o considera proporcional e adequado em todas

\footnotetext{
212 Nesse sentido: "Não estou a ajuizar senão isto: a potencialidade de algo para se tornar pessoa humana já é meritória o bastante para acobertá-lo, infraconstitucionalmente, contra tentativas esdrúxulas, levianas ou frívolas de obstar sua natural continuidade fisiológica. Mas as três realidades não se confundem: o embrião é o embrião, o feto é o feto e a pessoa humana é a pessoa humana. Esta não se antecipa à metamorfose dos outros dois organismos. É o produto final dessa metamorfose. O sufixo grego 'meta' a significar, aqui, u'a mudança tal de estado que implica um ir além de si mesmo para se tornar um outro ser. Tal como se dá entre a planta e a semente, a chuva e a nuvem, a borboleta e a crisálida, a crisálida e a lagarta (e ninguém afirma que a semente já seja a planta, a nuvem, a chuva, a lagarta, a crisálida, a crisálida, a borboleta). O elemento anterior como que tendo de se imolar para o nascimento do posterior. Donde não existir pessoa humana embrionária, mas embrião de pessoa humana, passando necessariamente por essa entidade a que chamamos 'feto'. Este e o embrião a merecer tutela infraconstitucional, por derivação da tutela que a própria Constituição dispensa à pessoa humana propriamente dita. Essa pessoa humana, agora sim, que tanto é parte do todo social quanto um todo à parte.
} 
as suas formas e interpretações possíveis. Afirma ele que toda gestação humana, de fato, principia com um embrião humano. Todavia, nem todo embrião humano origina uma gestação igualmente humana, situação em que deixam de coincidir a concepção e o nascituro, principalmente nas hipóteses em que, havendo fertilização in vitro - como previsto na lei -, não inoculado o óvulo fecundado no útero materno, não se verifica possibilidade de gestação daquela específica concepção ocorrida externamente ao corpo feminino.

Desse modo, quando o dispositivo legal questionado prevê que as pesquisas somente podem se dar com células-tronco embrionárias decorrentes de fertilização in vitro e com prévia e específica autorização dos doadores do material genético - que desistem, por esse ato, de tentar aproveitar referido material para uma concepção futura - são atendidos todos os pressupostos necessários a diferenciar a conduta em questão de qualquer forma de aborto, afigurando-se a legislação absolutamente proporcional e adequada.

Da mesma forma, nem se pode cogitar de que os embriões que serão utilizados para as pesquisas, de acordo com os ditames e regulamentos da lei, tenham potencialidade de gestação e vida, pois a concepção in vitro com a manutenção do material genético com esse acondicionamento, impede qualquer desenvolvimento reprodutivo, pois o embrião não tem capacidade de desenvolver-se sozinho, a não ser que introduzido em útero feminino preparado para a concepção e o desenvolvimento do óvulo então já fecundado.

Contudo, ao passo que não possui a capacidade de se desenvolver em feto, o embrião então fecundado, todavia, conserva a totipotência de se diferenciar em todos os tipos de tecidos do corpo humano, possibilidade essa que só se encontra, ao menos ao tempo do voto, nos embriões. E tendo em vista essa potencialidade, frente à impossibilidade do desenvolvimento do embrião referido em vida humana, certamente que se deve priorizar e privilegiar essa segunda possibilidade, autorizando a realização das pesquisas previstas pela Lei de Biossegurança.

Assim, tendo em vista que a Lei de Biossegurança não autoriza a retirada de embrião fecundado do útero feminino, mas apenas a utilização de embriões que 
tenham sido fecundados artificialmente e que permaneçam congelados in vitro, é evidente que não há que se falar na interrupção do desenvolvimento da potencialidade de vida humana in casu. Além do mais, referidos embriões, caso não utilizados para os fins de reprodução assistida, serão descartados como dejetos clínicos ou hospitalares, o que reforça ainda mais a possibilidade de seu uso para fins terapêuticos e científicos, desde que cumpridas todas as condicionantes cuidadosamente expostas pela lei.

Além disso, asseverou o Relator que o ordenamento constitucional, por meio de diversas normas que regulam a proteção à família e a possibilidade de realização de planejamento familiar e paternidade responsável, todas elas derivadas do primado da dignidade da pessoa humana, conferem bases para a aceitação da adoção do método da fertilização in vitro.

E a aceitação de tal método, por sua vez, não obriga a mulher a ver implantados todos os embriões efetivamente fecundados, inclusive em virtude da proteção ao direito do planejamento familiar. E diante de todos esses parâmetros, assim concluiu o Ministro Relator:

\begin{abstract}
"Remarco a tessitura do raciocínio: se todo casal tem o direito de procriar; se esse direito pode passar por sucessivos testes de fecundação in vitro; se é da contingência do cultivo ou testes in vitro a produção de embriões em número superior à disposição do casal para aproveitá-los procriativamente; se não existe, enfim, o dever legal do casal quanto a esse cabal aproveitamento genético, então as alternativas que restavam à Lei de Biosssegurança eram somente estas: a primeira, condenar os embriões à perpetuidade da pena de prisão em congelados tubos de ensaio; a segunda, deixar que os estabelecimentos médicos de procriação assistida prosseguissem em sua faina de jogar no lixo tudo quanto fosse embrião não-requestado para o fim de procriação humana; a terceira opção estaria, exatamente, na autorização que fez o art. $5^{\circ}$ da lei. Mas uma autorização que se fez debaixo de judiciosos parâmetros, sem cujo atendimento o embrião in vitro passa a gozar de inviolabilidade ontológica até então não explicitamente assegurada por nenhum diploma legal (pensa-se mais na autorização que a lei veiculou do que no modo necessário, adequado e proporcional como o fez).”
\end{abstract}

Em seguida, o Ministro Relator invocou o artigo 199, $\S 4^{\circ}$, da Constituição Federal $^{213}$, para afirmar a conformidade da Lei de Biossegurança com esse dispositivo

\footnotetext{
${ }^{213}$ Art. 199. A assistência à saúde é livre à iniciativa privada.

(...)

$\S 4^{\circ}$ - A lei disporá sobre as condições e os requisitos que facilitem a remoção de órgãos, tecidos e substâncias humanas para fins de transplante, pesquisa e tratamento, bem como a coleta, processamento e transfusão de sangue e seus derivados, sendo vedado todo tipo de comercialização.
} 
constitucional e reforçar a adequação e proporcionalidade do normativo então questionado.

Da mesma maneira, o dispositivo questionado encontra compatibilidade com a Lei $n^{\circ}$ 9.434/97, que regulamenta a doação de órgãos e que prevê como momento de cessação da vida a morte encefálica - para o Relator, a interpretação conjunta de todos esses dispositivos legais apenas reforçaria a adequação do artigo $5^{\circ}$ da Lei de Biossegurança, pois o embrião in vitro não teria e nem teria a possibilidade de vir a ter as terminações nervosas que poderiam vir a caracterizar a vida.

Assim, conclui que a vida humana, para o Direito brasileiro, seria " $o$ fenômeno que transcorre entre o nascimento com vida e a morte cerebral".

E desse modo, o embrião que é objeto da Lei de Biossegurança não teria vida e nem potencialidade de vida, mas teria perspectivas de contribuir para pesquisas e tratamentos que poderiam, futuramente, ajudar pessoas que - essas sim, com vida em toda a sua plenitude - sofressem de algum $\mathrm{mal}^{214}$.

E essa concepção decorreria de um Constitucionalismo fraternal, novo paradigma surgido após a consolidação efetiva do Constitucionalismo liberal e do social e que privilegiaria a vida em comunidade, a preocupação com o próximo, a solidariedade, prevista essa última, inclusive, no inciso I do artigo $3^{\circ}$ da Constituição ${ }^{215}$.

Por fim, antes de declarar seu voto pela total improcedência da ADI, o Ministro Relator ainda invocou dois importantes direitos fundamentais constitucionalmente previstos - o direito à saúde e o da livre expressão do pensamento científico -, pontuando estarem ambos, combinados, a permitir e até mesmo a estimular o

\footnotetext{
${ }^{214}$ A esse respeito: "Chego a uma terceira síntese parcial: se à lei ordinária é permitido fazer coincidir a morte encefálica com a cessação da vida de uma dada pessoa humana; se já está assim positivamente regrado que a morte encefálica é o preciso ponto terminal da personalizada existência humana, a justificar a remoção de órgão, tecidos e partes do corpo ainda fisicamente pulsante para fins de transplante, pesquisa e tratamento; se, enfim, o embrião humano a que se reporta o art. $5^{\circ}$ da lei de Biossegurança constitui-se num ente absolutamente incapaz de qualquer resquício de vida encefálica, então a afirmação de incompatibilidade deste último diploma legal com a Constituição é de ser plena e prontamente rechaçada. É afirmativa inteiramente órfã de suporte jurídico-positivo, sem embargo da inquestionável pureza de propósitos e da franca honestidade intelectual dos que a fazem."

${ }^{215}$ Art. $3^{\circ}$ Constituem objetivos fundamentais da República Federativa do Brasil:

I - construir uma sociedade livre, justa e solidária;
} 
quanto previsto no dispositivo legal questionado, mormente tendo em vista a ausência de potencialidade de vida do embrião que será utilizado para pesquisas, contraposta à concreta esperança de uma vida melhor a milhões de pessoas que sofrem de patologias ainda hoje sem cura.

Proferido o voto do Ministro Relator, adiantou o voto a então Ministra Presidente da Corte, Ellen Gracie, que acompanhou o Relator por seus próprios fundamentos, reforçando que a Lei de Biossegurança prevê como suscetíveis de objeto para pesquisa apenas os pré-embriões que não forem implantados no útero, não adquirindo, esses pré-embriões, vida, potencialidade de vida ou mesmo a condição de nascituro, uma vez que serão eles considerados inviáveis e destinados ao descarte, portanto, sem qualquer condição de vir a ter vida.

Reforçou, ainda, a Ministra Ellen Gracie, que não cabia à Suprema Corte definir conceitos que a Constituição houvera optado por não especificar, sequer implícita ou explicitamente, o que deveria ficar resguardado à atuação legislativa. Competia apenas definir se havia compatibilidade do artigo $5^{\circ}$ da Lei de Biossegurança com os valores constitucionais como dispostos no momento.

Por fim, afirmou a razoabilidade e adequação da lei e de todas as suas condicionantes e reconheceu que também deveria ser feito uso do princípio utilitarista, segundo o qual deveria ser buscado o resultado mais eficaz com o menor sacrifício possível, o que levava à conclusão de que o uso dos pré-embriões que não serão efetivamente utilizados para reprodução humana para fins de pesquisa científica e terapêutica é infinitamente mais proveitoso do que o seu descarte.

Tendo concluído seu voto para acompanhar o Ministro Relator na improcedência da ADI, pediu vista dos autos o Ministro Menezes Direito, que trouxe seu voto posteriormente no sentido de dar parcial provimento à $\mathrm{ADI}$, sob os fundamentos que abaixo explicitamos.

O Ministro iniciou seu raciocínio com uma digressão acerca do histórico das pesquisas com células-tronco - adultas e embrionárias - e da diferenciação entre cada uma delas. Adentrou, ainda, no detalhamento do processo de fertilização in vitro, 
concluindo que nem todos os embriões fecundados são implantados no útero da mulher, sendo que parte deles, quando considerada de média ou alta viabilidade, é armazenada, enquanto aqueles considerados inviáveis são descartados como lixo biológico.

Afirmou, ainda, com base em artigos científicos que citou, que a retirada das células-tronco embrionárias necessariamente implica a destruição do embrião e concluiu que a questão a ser analisada pelo Supremo Tribunal Federal era exatamente a legalidade/constitucionalidade desse método de obtenção das células por meio da destruição do embrião.

Ressaltou o Ministro que a questão atinente à maior eficácia das pesquisas com células-tronco embrionária quando em comparação com as pesquisas feitas com as células-tronco adultas não deveria permear o raciocínio da Corte, mas que o Tribunal deveria levar em consideração que o progresso científico pode necessitar de limites éticos para se assegurar o respeito à dignidade da pessoa humana e até mesmo o marco definidor da espécie humana.

Em seguida, fazendo uma análise de direito comparado e citando os países que permitem e aqueles que não permitem a pesquisa com células-tronco embrionárias, o Ministro Menezes Direito procurou mostrar que até mesmo aqueles países que possibilitaram essas pesquisas adotaram legislações e regulamentações rígidas, colocando restrições e condicionantes para a autorização das pesquisas, além de prever mecanismos de controle e fiscalização.

Concluiu, então, que a lei brasileira não era satisfatória nesse ponto, por não prever elementos e regulamentações suficientes sobre as pesquisas, o que representava riscos concretos à dignidade da pessoa humana, como a possibilidade de se configurar manipulação genética e eugenia.

Assim, previu que os valores éticos deveriam se sobrepor a qualquer valor científico e de desenvolvimento e que esses valores necessariamente teriam de permitir que se colocasse em freio nas pesquisas, permitindo o seu controle e a instituição de limitações que evitassem esses riscos concretos. 
A seguir, buscou o Ministro definir sua posição sobre o início da vida, questão essa que entendeu essencial para opinar sobre a constitucionalidade do artigo analisado. Para ele, o embrião como tal já é um ser em potencia e essência. Ou seja, havendo a fecundação, já há vida, pois o embrião desenvolve-se de forma individualizada, ainda que fora do útero, até um certo estágio, o que comprova que ele se desenvolveria de qualquer maneira.

Do mesmo modo, rejeitou o argumento analógico em relação à afirmação de que a morte é considerada quando se afigura a morte cerebral, uma vez que não se poderia usar o mesmo parâmetro com o embrião e que nem se aceita o referido método como infalível.

Igualmente manifestou-se rechaçando a diferenciação entre o embrião que é implantado no útero e aquele que acaba por não sê-lo, rejeitando o argumento de que apenas com a implantação no útero haverá a possibilidade de vida. Repetiu o Ministro que a possibilidade e a potência de vida são conceitos diversos e no caso do embrião há sempre potência de vida, que somente não irá concretizar-se caso se oponha algum fator externo impeditivo.

Ademais, a vocação natural dos óvulos fecundados in vitro que se transformam em embrião é precisamente a sua implantação no útero materno e, portanto, a sua reprodução e desenvolvimento, mesmo porque a única possibilidade autorizada de fertilização in vitro no Brasil é aquela para fins de reprodução humana.

Todavia, a destruição do embrião -- que ocorre inequivocamente quando se configura a retirada das células-tronco embrionárias para fins de pesquisa -- impede essa sua potencialidade e retira dele a possibilidade de se desenvolver e de cumprir o seu destino natural que é o de atender à reprodução humana.

E fazendo novamente referência a textos científicos, o Ministro Menezes Direito adota a posição de que o desenvolvimento humano inicia-se com a fecundação, 
adotando, portanto, o entendimento de que o embrião já representa vida humana passível de proteção legal ${ }^{216}$.

Para o Ministro, seria absolutamente incompatível a colocação de marcos temporais no desenvolvimento do embrião para fins de estipular o momento de início da vida. Para ele, agindo assim, estar-se-ia, de um lado, a reconhecer haver vida no embrião, ao passo em que, por outro lado, reconheceria que, apesar de não ter personalidade, em relação ao embrião deveria ser protegida a dignidade da pessoa humana.

Acrescenta-se que o raciocínio acima explicado e a analogia entre a definição da morte cerebral e o estabelecimento de que as pesquisas com as célulastronco embrionárias podem ser feitas até que se iniciem os primeiros impulsos nervosos $14^{\circ}$ dia - acabariam por relativizar o princípio da dignidade da pessoa humana ao assumir que o embrião teria apenas direito a parcial a essa dignidade.

Mas o só reconhecimento de que o embrião tem vida humana não é suficiente para concluir. Por isso, passa o Ministro a explicar que o direito à vida possui duas facetas: (i) o direito à permanecer vivo; e (ii) o direito à subsistência.

O embrião, como vida humana, está protegido pela Constituição quando estatui a inviolabilidade do direito à vida. Diante disso, para possibilitar a análise do caso concreto, o Ministro dirigiu-se ao texto do artigo impugnado e verificou as hipóteses em que autorizada a pesquisa com a célula-tronco embrionária para verificar se alguma delas viola o direito à vida e decidir a questão colocada na ação.

Para ele, os embriões congelados são embriões com vida e o congelamento por si só não tem o condão de retirar-lhes essa condição. Ainda citando artigos científicos, afirma que nem mesmo o transcurso do prazo de 3 (três) anos na condição de congelamento é capaz de retirar a vida do embrião, pois mesmo após esse período é possível a sua implantação no útero e a sua reprodução normal.

\footnotetext{
${ }^{216}$ Foram essas as exatas palavras utilizadas pelo Ministro Menezes Direito em seu voto: "O embrião é, desde a fecundação, mais precisamente desde a união dos núcleos do óvulo e do espermatozoide, um indivíduo, um representante da espécie humana, com toda a carga genética (DNA) que será a mesma do feto, do recém-nascido, da criança, do adolescente, do adulto, do velho. Não há diferença ontológica entre essas fases que justifique a algumas a proteção de sua continuidade e a outras não."
} 
Concluiu que, no ponto em que a lei autorizava a realização de pesquisas de célula-tronco embrionárias com essa espécie de embrião, seria inconstitucional, por representar violação ao direito à vida.

E ainda refutou o argumento daqueles que alegam que os embriões em questão serão descartados, de forma que é a melhor solução emprega-los para fins de pesquisas que podem inclusive curar patologias graves e ainda desprovidas de cura e tratamento eficazes. Para o Ministro, além do fato de não haver ainda comprovação da eficácia das pesquisas, não se pode adotar o posicionamento utilitarista sem critério ou crítica, de forma que os valores éticos devem se sobrepor, pois não se pode aceitar que se destrua uma vida sob o pretexto de proteger uma outra eventualmente no futuro.

Quanto à constitucionalidade da previsão legal de realização de pesquisas com embriões considerados "inviáveis", concluiu o Ministro que a lei não define o que seriam esses embriões inviáveis e nem tampouco a ciência possui um critério prédefinido e padronizado de caracterização.

Não obstante a lei não tenha definido essa espécie de embriões, o Decreto $\mathrm{n}^{\mathrm{o}}$ 5.591/05 o fez e, diante desses critérios o Ministro Menezes Direito analisou se teria ou não havido violação à Constituição.

Partindo da conclusão de que a definição da inviabilidade do embrião não dizia respeito a ele possuir ou não vida, mas sim a ter sido identificada anomalia em seu desenvolvimento, o Ministro conclui que também aqui deveria ser reconhecida uma inconstitucionalidade, uma vez que, apesar de identificada alteração morfológica no embrião, ele é passível de alcançar gravidez e nascimento - mesmo que sejam baixas as probabilidades - e ele possui vida, o que gera a consequente proteção constitucional.

Por fim, analisando a parte média do inciso XIII do artigo $3^{\circ}$ do Decreto $n^{\circ}$ 5.591/05, concluiu o Ministro que os embriões considerados inviáveis porque "sofreram ausência espontânea de clivagem após um periodo superior de vinte e quatro horas", poderiam, eles sim, ser objeto de pesquisas com células-tronco embrionárias, uma vez que teriam deixado espontaneamente de se desenvolver, perdendo a potencialidade para a 
vida, de forma que a retirada de suas células não implicaria qualquer violação ao direito à vida.

Assim, para que esses limites éticos sejam observados e ao mesmo tempo se permita a realização das pesquisas então invocadas, o Ministro Menezes Direito propôs a autorização da extração das células-tronco apenas com métodos que não implicassem a destruição do embrião, os quais, segundo eles, existem e são plenamente eficazes, a despeito de permitirem a extração de apenas uma ou duas células por embrião.

Finalizando, o Ministro ressaltou a importância de se estabelecerem mecanismos de fiscalização e controle centrais, tanto em relação às clínicas de reprodução assistida, como quanto no tocante às pesquisas em si, ressalvando-se sempre o limite de autorização das pesquisas com a adoção de técnicas que impeçam a destruição do embrião.

Assim, declarou a lei inconstitucional, sem redução de texto, para aplicar as interpretações acima narradas na efetiva vigência do dispositivo legal questionado.

O Ministro Ayres Brito, relator, pediu novamente a palavra para rebater a ideia de ocorrência da destruição do embrião, aduzindo que o que ocorre é apenas o resgate da perspectiva de vida em uma terceira pessoa que se beneficiar das pesquisas eventualmente feitas com as células-tronco oriundas daquele embrião. Além disso, reforça que o princípio da proteção da dignidade da pessoa humana é aplicável apenas à pessoa humana, ou seja, a um ser dotado de personalidade - não a um embrião.

Em seguida, votou a Ministra Cármen Lúcia, que começou por afirmar que o princípio da dignidade da pessoa humana tinha por desdobramento a proibição de utilização da espécie humana para fins comerciais, eugênicos e experimentais. E, diante desse conceito de dignidade da pessoa humana, os Ministros teriam que definir, pela análise dos dispositivos legais questionados, se eles teriam o condão de compatibilizar esse primeiro conceito com a posição também constitucional de liberdade de pesquisa.

Iniciou sua análise acerca da constitucionalidade da autorização legal de uso das células-tronco embrionárias para fins terapêuticos. Concluiu, nesse ponto, que a 
norma somente seria compatível com a Constituição caso o fim terapêutico se restringisse ao conceito de tratamento, impedindo a utilização de seres humanos como cobaias com pesquisas de experimentação que se considerassem terapêuticas. Tal preocupação, ressaltou a Ministra, decorreria de da proteção da dignidade da pessoa humana que se pudesse submeter a testes ainda sem comprovação de eficácia científica, e não propriamente ao uso das células-tronco embrionárias para esse fim.

No tocante à alegação da PGR, na inicial da ADI, no sentido de que a permissão de realização de pesquisas com células-tronco embrionárias corresponderia a uma violação do direito à vida, expôs a Ministra que esse direito, assim como todos os outros princípios fundamentais do ordenamento, não deveria ser interpretado como um direito absoluto, comportando ponderações para se conformar com outros direitos e resultar em uma dinâmica constitucional coerente.

Assim, aduziu de pronto que o próprio ordenamento nacional flexibilizava a inviolabilidade do direito à vida quando permitia, por exemplo, o aborto para preservar a vida da mãe ou quando a gestação decorresse de estupro. Além disso, pontuou que o direito à vida e a sua inviolabilidade constitucionalmente assegurada dependiam da análise de proteção de outros direitos essenciais a seu efetivo gozo, como o de liberdade e o direito à saúde, os quais passou a analisar.

Segundo ela, ao garantir a liberdade de pesquisa científica, de informação a seu respeito e de uso de seus resultados (liberdade de expressão da atividade intelectual e científica), a Constituição estaria, por uma dimensão diferente, também garantindo uma vida digna ${ }^{217}$. Da mesma forma, não se poderia, sob a pretensão de se estar a proteger a inviolabilidade do direito à vida do embrião, negar àqueles que não gozam de sua plena saúde a esperança e a expectativa de se encontrar uma solução médico-científica para

\footnotetext{
${ }^{217}$ Nesse ponto, a Ministra Cármen Lúcia faz referência aos seguintes artigos da Constituição: Art. $5^{\circ}$ Todos são iguais perante a lei, sem distinção de qualquer natureza, garantindo-se aos brasileiros e aos estrangeiros residentes no País a inviolabilidade do direito à vida, à liberdade, à igualdade, à segurança e à propriedade, nos termos seguintes: (...)

IX - é livre a expressão da atividade intelectual, artística, científica e de comunicação, independentemente de censura ou licença;

Art. 218. O Estado promoverá e incentivará o desenvolvimento científico, a pesquisa e a capacitação tecnológicas.

$\S 1^{\circ}$ - A pesquisa científica básica receberá tratamento prioritário do Estado, tendo em vista o bem público e o progresso das ciências.
} 
solucionar o problema que os aflige, mormente tendo em vista que a pesquisa só é permitida com aqueles embriões que nunca virão a ser implantados no útero.

Em seguida, a Ministra também refuta o argumento dos defensores da ADI de que a lei seria incompatível com o artigo $4^{\circ}$ do Pacto de San José da Costa Rica, de que o Brasil é signatário, pois referido dispositivo preconiza a proteção da vida desde a concepção, nos seguintes termos: "Toda pessoa tem o direito de que se respeite sua vida. Esse direito deve ser protegido pela lei e, em geral, desde o momento da concepção. Ninguém pode ser privado da vida arbitrariamente”.

Contudo, analisando o conteúdo desse dispositivo da legislação internacional, a Ministra chamou a atenção para a última parte do dispositivo, que explicita que o direito à vida não deverá ser violado desde que essa violação seja arbitrária, para concluir que o dispositivo legal objeto da ADI jamais poderia ser considerado incompatível com o Pacto de San José da Costa Rica, uma vez que as pesquisas com células-tronco embrionárias, conforme regulamentadas pela Lei discutida, jamais poderiam ser consideradas como forma arbitrária de privação da vida, além de estarem em total conformidade com outros regramentos constitucionais diversos ${ }^{218}$.

Além disso, afirma a Ministra, a Constituição ainda estatui, no artigo 225, $\S 1^{\circ}$, inciso II, o princípio da solidariedade entre as gerações, o qual é também preservado pelas normas questionados por meio da ADI, tendo em vista a previsão de físcalização por entidades especializadas, que também regulamentarão e aprovarão as pesquisas que forem ser realizadas com essa espécie de material genético.

Quanto ao respeito ao princípio da dignidade da pessoa humana, a Ministra ressalta que a Constituição brasileira, ao prevê-lo, refere-se apenas a que "todos são iguais perante a lei, ${ }^{, 219}$, deixando em aberto o momento em que se titularizam os direitos

\footnotetext{
${ }^{218}$ Nesse ponto, a Ministra fez referência ao $§ 4^{\circ}$ do artigo 199 da Constituição, verbis: Art. 199. A assistência à saúde é livre à iniciativa privada.

(...)

$\S 4^{\circ}$ - A lei disporá sobre as condições e os requisitos que facilitem a remoção de órgãos, tecidos e substâncias humanas para fins de transplante, pesquisa e tratamento, bem como a coleta, processamento e transfusão de sangue e seus derivados, sendo vedado todo tipo de comercialização.

219 Trata-se do caput do artigo 50: "Todos são iguais perante a lei, sem distinção de qualquer natureza, garantindo-se aos brasileiros e aos estrangeiros residentes no País a inviolabilidade do direito à vida, à liberdade, à igualdade, à segurança e à propriedade, nos termos seguintes (...)”
} 
fundamentais previstos naquele dispositivo constitucional. Todavia, ao se analisar o caso concreto, não se poderia fugir à conclusão de que o uso das células-tronco embrionárias para fins de pesquisa valorizaria a dignidade da pessoa humana, uma vez que permitiria àqueles embriões inviáveis e que jamais seria utilizados para fins de reprodução, que tivessem uma funcionalidade interessante e apta a dignificar a vida de terceiros.

E para a Ministra, impedir, sem qualquer justificativa jurídica ou ética, o desenvolvimento de uma linha de pesquisa, seria também uma forma de violar o princípio da dignidade da pessoa humana.

Por essas razões, e fundada principalmente na dignidade da pessoa humana, que classificou de superprincípio constitucional, a Ministra votou pela improcedência da ADI.

Em seguida, votou o Ministro Ricardo Lewandowski que analisou o momento em que se inicia a vida. Segundo ele, no âmbito jurídico, excluídas as considerações religiosas ou filosóficas sobre o tema, existiriam fortes indícios de que a vida teria início com a concepção, apontando como fundamento de sua posição o Pacto de San José da Costa Rica, ratificado pelo Brasil com caráter supralegal.

Colocada essa premissa, o Ministro propõe que a questão central a ser analisada diga respeito ao direito à vida como bem coletivo, levando ainda em consideração postulado da dignidade da pessoa humana e do princípio da precaução.

Assim, e também com base em resolução do Conselho Federal de Medicina e em análises de direito comparado, posicionou-se no sentido de que o artigo $5^{\circ}$ da Lei de Biossegurança deveria ser harmonizado com os princípios citados acima.

A primeira harmonização derivaria da impossibilidade de se descartar embriões com base em um controle de qualidade genérico, sob pena de configurar discriminação incompatível com o Estado Democrático de Direito. Da mesma forma seria uma afronta ao princípio da isonomia a disposição que permite a destruição dos embriões após três anos de congelamento, uma vez que há casos de embriões com muito mais idade que isso que continuaram viáveis. 
Da mesma forma, entendeu o Ministro que a mera requisição de autorização dos geradores do embrião para a realização das pesquisas seria insuficiente, pois os casais deveriam ter maiores informações sobre as possibilidades de aproveitamento daqueles embriões para que pudessem de fato manifestar seu livre consentimento informado.

Igualmente entendeu o Ministro que os Comitês de Ética previstos na lei seriam insuficientes para a avaliar a viabilidade das pesquisas, a não ser que houvesse previsão específica de que sua composição se desse de forma pluralista, sob pena de se colocar nas mãos dos próprios interessados as decisões sobre a viabilidade ou não dos estudos.

Com base nesses argumentos, então, o Ministro Lewandowski houve por bem julgar parcialmente procedente a ADI para, sem redução de texto, prever restrições à interpretação dos dispositivos, determinando que as pesquisas com células-tronco embrionárias somente poderiam ser realizadas com embriões humanos inviáveis ou congelados logo após o início do processo de clivagem celular e desde que o processo de obtenção dos embriões respeitasse o limite necessário apenas para os fins de reprodução assistida.

Determinou, ainda, que fossem considerados inviáveis apenas aqueles embriões com desenvolvimento interrompido por ausência espontânea de clivagem e que as pesquisas fossem admitidas apenas se os embriões não fossem destruídos e não tivessem o seu potencial de desenvolvimento comprometido, condicionando ainda o convencimento dos genitores a um juízo livre e informado e submetendo as autorizações a Conselhos de Ética pluralmente formados.

Em seguida, votou o Ministro Eros Grau afirmando que, como o nascituro (que é o embrião formado no ventre materno) é sujeito de direito protegido pela legislação, deve-se considerar que já é dotado de vida e já é uma pessoa. Contudo, seria necessário que esse embrião estivesse no útero, senão não poderia ser considerado como nascituro e nem ser vivo. 
Assim, votou o Ministro pela constitucionalidade do artigo $5^{\circ}$ e de seus parágrafos, propondo, contudo, uma decisão aditiva para que fossem impostos os seguintes requisitos às normas legais: (a) as pesquisas e terapias apenas seriam admitidas se previamente autorizadas por comitê de ética e pesquisa do Ministério da Saúde; (b) a fertilização in vitro deveria permanecer com o fim exclusivo de uso para reprodução humana assistida; e (c) a obtenção das células-tronco apenas seria possível caso não resultassem na destruição do embrião ou caso fossem feitas em embriões inviáveis.

Também o Ministro Joaquim Barbosa, que votou em seguida, evitou nortear a discussão na definição do momento de início da vida. Para ele, haveria que se analisar se a legislação estaria compatível com uma dimensão coletiva do direito à vida ou seja, verificar também os direitos daqueles que se beneficiariam das pesquisas, e não apenas o eventual direito do embrião.

Além disso, apontou que a lei traz mera faculdade de realização das pesquisas, condicionada pelo estabelecimento de três restrições bem fundamentadas. Nesse sentido, para o Ministro Joaquim Barbosa, a lei respeitaria três postulados fundamentais da República: a laicidade do Estado, o respeito à liberdade e à autonomia privada, e o respeito à liberdade de expressão da atividade intelectual e científica. E, dessa forma, acompanhou o Relator para julgar improcedente a ADI.

Votou em seguida o Ministro Cezar Peluso manifestando que a questão central a ser decidida pelo Supremo seria a ausência ou presença de vida nos embriões, mais especificamente naqueles inviáveis e nos crioconservados (congelados).

Para o Ministro, os embriões, antes de implantados, não possuiriam vida suscetível de tutela na acepção do ordenamento constitucional e nem expectativa de direito à vida. Além disso, muito mais indigno seria manter os embriões congelados ou destruí-los e joga-los fora do que aproveita-los em pesquisas científicas devidamente aprovadas.

Não obstante, sustentou o Ministro que os embriões humanos possuem dignidade constitucional, ainda que em grau diverso daquele conferido à vida das pessoas 
humanas, divergindo, nesse ponto, do Relator que afirmou que os embriões tinham proteção infraconstitucional.

Assim, julgou improcedente a ADI e votou por atribuir interpretação conforme à Constituição para que a fertilização in vitro continuasse restrita apenas às finalidades de produção assistida, para que os funcionários componentes dos órgãos de controle estivessem sujeitos às penas do artigo 319 do CP e para que ainda outros órgãos de fiscalização fossem adicionados ao rol de responsáveis pelo controle das pesquisas.

Em seguida, o Ministro Marco Aurélio acompanhou o Relator julgando improcedente a ADI e fazendo uma ressalva quanto à interpretação conforme à Constituição, opinando que ela poderia acabar por representar a atuação da Corte como legislador positivo e, portanto, de forma contrária aos limites de atuação impostos pela própria Constituição.

Votou, então, o Ministro Celso de Mello. Apontando diversas concepções teóricas sobre o início da vida, o Ministro opinou que, nesse caso, caberia ao intérprete escolher uma justificativa científica que mais se compatibilizasse com o interesse público e atendesse as exigências sociais do desenvolvimento de pesquisas científicas. Assim, adotando também as razões de decidir do Relator, o Ministro o acompanhou integralmente, julgando improcedente a ADI.

Por fim, votou o então Presidente da Corte, Ministro Gilmar Mendes, ressaltando desde o início que o resultado do julgamento representava o resultado do compromisso crescente do Supremo com a defesa e efetividade dos direitos fundamentais no Estado Democrático de Direito.

Então, realizando um juízo de proporcionalidade e também de direito comparado, o Ministro concluiu que a lei brasileira, apesar de previsões genéricas sobre todos os temas de importância relacionados à legislação, afigurava-se na realidade frágil e deficiente, suscitando a necessidade de pronunciamentos aditivos.

Assim, votou também pela improcedência da ADI, condicionando a interpretação no sentido de que as pesquisas com as células-tronco deveriam ser 
submetidas, além de aos órgãos já mencionados na lei, a um comitê de ética central vinculado ao Ministério da Saúde.

Assim, foi julgada improcedente a ADI, mantendo-se a constitucionalidade dos dispositivos impugnados e a autorização legal para a realização de pesquisas com células-tronco embrionárias no Brasil.

\subsection{Conclusão parcial sobre a postura do Supremo Tribunal Federal na hipótese}

Quando se verifica, previamente à análise do acórdão, a discussão que foi colocada em jogo no presente julgamento, a tendência é a de achar que o Supremo Tribunal Federal irá discutir a constitucionalidade ou inconstitucionalidade das pesquisas com base na definição do momento de início da vida - estabelecendo que o embrião já é dotado dela, seriam impedidas as pesquisas e, caso contrário, seriam permitidas.

Contudo, outra tendência fez-se unânime na análise concreta do caso: os Ministros buscaram se esquivar da questão mais polêmica e menos jurídica invocada pelo caso em questão - o momento de início da vida - voltando-se a outros princípios em jogo a fim de fundamentar o seu raciocínio.

Os que não refutaram desde o início que o julgamento trataria dessa questão específica, adotaram de pronto interpretações que tangenciaram essa questão, passando mais por considerações abrangentes sobre o direito à vida, notadamente relativas ao princípio da dignidade da pessoa humana e ao direito de informação e liberdade de pesquisa científica.

E mesmo assim muitos deles afirmaram que esse era um dos julgamentos mais importantes da Corte, tendo em vista as suas consequências e as possibilidades concretas dele decorrentes.

A escolha para análise do caso em questão teve uma razão específica. Além de ter sido absolutamente relevante em termo sociais, ele pode revelar e reforçar ainda mais as características da postura ativa adotada pelo Supremo Tribunal Federal em relação aos direitos fundamentais. 
Isso porque, nesse caso específico, a questão analisada era menos jurídica do que fática, científica, moral e até mesmo religiosa, o que mostra a faceta do Supremo também quando confrontado com questões não amplamente jurídicas e eminentemente morais e políticas.

Como visto, na justificação externa de suas premissas, os Ministros fizeram amplo uso de cânones argumentativos comparativos e históricos e de técnicas sistemáticas de interpretação de princípios, passando ao largo da alegada violação ao direito à vida para invocar princípios outros como o da liberdade de expressão científica e o da dignidade da pessoa humana para fundamentar a constitucionalidade do dispositivo legal questionado.

Isso se deu, a nosso ver, também por razões práticas de justificação racional da interpretação jurídica, uma vez que dificilmente é possível colocar-se na balança da ponderação qualquer direito que pese tanto ou mais que o direito à vida.

Portanto, também recusando-se a adentrar no mérito da questão e a definir qual seria o momento de início da vida, os Ministros desviaram o foco inicialmente colocado na ação para tangenciar a questão principal e solucionar o problema por meio da interpretação e ponderação de valores outros, como os que acima apontamos.

Igualmente foram de extrema relevância na análise do presente caso as considerações empíricas e de ordem fática que foram inclusive objeto de audiência pública realizada no âmbito do Supremo Tribunal Federal e que fundamentaram grande parte dos votos, mormente quando se levou em consideração o destino dos embriões, as formas de fertilização in vitro e outras questões técnicas e fáticas que muito se distanciam do mundo jurídico.

Não obstante os fatos e premissas concretas do julgamento sejam distantes dos argumentos jurídicos geralmente enfrentados pela Corte Constitucional, ela foi instigada a se manifestar sobre a constitucionalidade da lei que, inclusive para sua aprovação no Congresso Nacional, contou com movimentos excepcionais de mobilização política - tanto favoráveis quanto contrários à medida. 
Ocorre que a lei em questão não alterou sentidos de dispositivos constitucionais e nem sequer modificou disciplina já anteriormente existente, o que desde logo refuta a aplicabilidade de argumentos genéticos e históricos, ou de uso de precedentes, reduzindo muito as possibilidades de fundamentação da Corte.

Sendo uma questão nova, fica evidente o recurso aos argumentos comparativos, voltando-se os Ministros à regulamentação da questão em outros países, bem como à interpretação sistemática que congrega todos os possíveis princípios constitucionais e direitos fundamentais em jogo, considerando-se a existência de uma ordem objetiva de valores a ser preservada pela interpretação judicial.

E assim sendo, não há possibilidade de se configurar mutação constitucional ou ativismo judicial, mas mera interpretação com base em princípios constitucionais e nos cânones interpretativos aplicáveis, os quais se revestem do requisito de saturação que torna racional a argumentação jurídica desenvolvida.

Por fim, esse último julgado analisado corrobora com a nossa visão de que a postura do Supremo Tribunal Federal na efetividade dos direitos fundamentais é ativa e que essa proatividade é decorrência da própria conformação constitucional das atividades judicantes, de modo que, agindo assim, o STF está a preservar a força normativa da Constituição não só no que diz respeito à preservação dos princípios, mas também no tocante às diretrizes institucionais de organização dos poderes. 


\section{A POSTURA DO SUPREMO TRIBUNAL FEDERAL NA EFETIVIDADE DOS DIREITOS FUNDAMENTAIS}

Acima fizemos um apanhado geral sobre a importância e origem dos direitos fundamentais e de sua positivação em textos constitucionais, a sua forma de interpretação e a racionalidade da técnica de ponderação a eles aplicável, bem como as consequências que a utilização dessa técnica poderia causar na postura do Supremo Tribunal Federal quando de sua aplicação efetiva aos casos concretos, analisando possibilidades de ativismo judicial e mutação constitucional.

Feitas as considerações introdutórias e definições de conceitos, selecionamos alguns grupos de direitos fundamentais cuja apreciação pelo Supremo Tribunal Federal, em alguns casos concretos, deveria ser objeto de nossa análise para identificar a postura da Corte na efetivação dos direitos fundamentais naqueles casos concretos.

Identificadas as hipóteses, em cada um dos casos estudados foi possível nos posicionar sobre a adequação da postura do Supremo, analisando os seus pontos em comum e as suas consequências e verificando o seu papel efetivo na promoção dos direitos fundamentais por meio de sua interpretação e aplicação aos casos concretos.

E diante de todas essas considerações, passamos abaixo a algumas conclusões específicas.

\subsection{A postura predominante na promoção da eficácia dos direitos fundamentais}

Como já alertamos anteriormente, os grupos de direitos fundamentais que escolhemos para estudar não são representativos da totalidade de direitos submetidos ao exame da Corte. Todavia, os casos analisados podem nos dar uma perspectiva concreta dos métodos adotados pelo Supremo Tribunal Federal, permitindo a identificação de sua postura quanto à efetividade dos direitos fundamentais. 
Conforme percebemos, em geral a postura do Supremo Tribunal Federal pode ser considerada ativa frente aos direitos fundamentais, buscando a sua efetiva concretização por meio de juízos de ponderação bem fundamentados e justificados interna e externamente, de acordo com os pressupostos da teoria do discurso acima examinados.

Percebemos que a postura adotada, muitas vezes, representa processo informal de modificação da Constituição - mutação constitucional - ao alterar e conferir novas interpretações e significados a direitos positivados, sejam eles de conformação genérica ou mesmo com espaço de definição semântica limitado.

O que se verifica, portanto, é uma preocupação da Corte Constitucional com a efetividade dos direitos fundamentais, reconhecendo a sua ímpar importância para o Estado Democrático de Direito, a configuração de uma ordem objetiva de valores, a atribuição de eficácia irradiante aos direitos e o consequente dever do Estado de protegelos, proporcionando terreno para que se realizem na maior medida possível.

Em decorrência dessa preocupação com os direitos fundamentais e do reconhecimento de sua vital importância, o Supremo Tribunal Federal tem adotado uma postura ativa nas causas que dizem respeito à proteção e garantia de efetividade desses direitos, aplicando-os diretamente e utilizando-os como parâmetros para interpretar situações e mesmo regras concretas.

Essa postura ativa, por muitas vezes, é alvo de críticas de diversos setores que procuram caracterizar ativismo judicial nas decisões proferidas pelo STF.

Contudo, grande parte dessas críticas são atécnicas, pois consideram ativismo judicial o que apenas podemos chamar de Judiciário ativo, esquecendo que ativismo judicial implica a atuação do Poder Judiciário fora das balizas definidas por lei para sua atuação.

Ora, quando o Supremo realiza juízos de ponderação, quando dá prevalência a princípios constitucionais sobre regras, quando aplica interpretações extensivas de institutos legais aparentemente já definidos, desde que realizando todas 
essas atividades com a devida fundamentação e com o objetivo de proteger e resguardar a eficácia da Constituição, ele não age fora das balizas de atuação do Poder Judiciário definidas constitucionalmente.

E se não age fora dessas balizas, não pode ser rotulado de ativista, como pretendem fazer vários críticos que não concordam com a prevalência dos princípios, com os juízos de ponderação e, consequentemente, também não concordam com a plena eficácia dos direitos fundamentais, que, no nosso entender, só é possível se admitidas as premissas anteriores.

É importante ressalvar que, em alguns casos, o Supremo Tribunal Federal apresenta, sim, comportamento ativista. E nessas hipóteses, nós também nos juntamos aos críticos para rechaçar esses posicionamentos.

É o que se deu, a nosso ver, no julgamento da constitucionalidade da Lei da Ficha Limpa, em que o Supremo modificou a interpretação conferida ao princípio da presunção de inocência, realizando verdadeira mutação constitucional que, no nosso entender, foi inconstitucional.

Isso porque a fundamentação dos juízos interpretativos que embasaram essa decisão foi baseada em premissas distorcidas sobre a abrangência da presunção de não-culpabilidade e sobre a configuração dos direitos políticos. E colocados ambos em confronto já com as premissas alteradas indevidamente, originou-se .um juízo de ponderação inadequado e propositadamente fabricado para atingir um resultado previamente esperado.

Talvez seja fácil utilizar o exemplo acima como modelo de decisão ativista porque não concordamos com o seu desfecho. Contudo, o mesmo raciocínio crítico pode ser aplicado também quando concordamos com o resultado da atuação ativista.

É o caso do exemplo utilizado pelo Professor Elival da Silva Ramos, acima já explicitado, e que diz respeito à redação e aprovação, pelo Supremo Tribunal 
Federal, da Súmula Vinculante $\mathrm{n}^{\mathrm{o}} 13^{220}$, que vedou a prática do nepotismo na Administração Pública ${ }^{221}$.

Não obstante concordemos absolutamente com os termos da Súmula Vinculante editada, bem como com os efeitos práticos que ela terá na efetividade dos princípios constitucionais republicanos, entendemos que no caso em questão houve inquestionável prática de ativismo judicial, com o Supremo Tribunal Federal agindo além dos limites de atuação definidos pelo texto constitucional.

Isso porque, a despeito de a edição de súmulas vinculantes estar prevista e regulamentada no próprio texto constitucional, ele é absolutamente claro quanto às hipóteses que autorizam a sua edição, sendo elas restritas aos casos em que houver decisões reiteradas da Corte a respeito de uma matéria específica ${ }^{222}$.

Contudo, no caso em comento, não houve decisão reiterada sobre a matéria, mas mera sugestão de edição de súmula, tendo o Supremo, nesse caso, arvoradose na condição de legislador, criando instrumento vinculante e com força executória a ser aplicado no âmbito de toda a Administração Pública, a despeito de ter extrapolado as suas possibilidades de atuação.

Essas manifestações de ativismo judicial, entretanto, não são a regra e, por conseguinte, não podem definir a postura do Supremo quanto à efetividade dos direitos fundamentais.

\footnotetext{
220 "A nomeação de cônjuge, companheiro ou parente em linha reta, colateral ou por afinidade, até o terceiro grau, inclusive, da autoridade nomeante ou de servidor da mesma pessoa jurídica, investido em cargo de direção, chefia ou assessoramento, para o exercício de cargo em comissão ou de confiança, ou, ainda, de função gratificada na Administração Pública direta e indireta, em qualquer dos Poderes da União, dos Estados, do Distrito Federal e dos municípios, compreendido o ajuste mediante designações recíprocas, viola a Constituição Federal."

${ }^{221}$ Vide NR 146.

${ }^{222}$ Art. 103-A. O Supremo Tribunal Federal poderá, de ofício ou por provocação, mediante decisão de dois terços dos seus membros, após reiteradas decisões sobre matéria constitucional, aprovar súmula que, a partir de sua publicação na imprensa oficial, terá efeito vinculante em relação aos demais órgãos do Poder Judiciário e à administração pública direta e indireta, nas esferas federal, estadual e municipal, bem como proceder à sua revisão ou cancelamento, na forma estabelecida em lei.

$\S 1^{\circ} \mathrm{A}$ súmula terá por objetivo a validade, a interpretação e a eficácia de normas determinadas, acerca das quais haja controvérsia atual entre órgãos judiciários ou entre esses e a administração pública que acarrete grave insegurança jurídica e relevante multiplicação de processos sobre questão idêntica.

$\S 2^{\circ}$ Sem prejuízo do que vier a ser estabelecido em lei, a aprovação, revisão ou cancelamento de súmula poderá ser provocada por aqueles que podem propor a ação direta de inconstitucionalidade.
} 
Por outro lado, verificamos como são frequentes, nos casos em que há análise e aplicação dos direitos fundamentais, as posturas que acarretam verdadeiras mutações constitucionais, que são processos informais de mudança da Constituição que podem se dar com ou sem alteração de texto e por meio de interpretações, ações ou omissões do Poder Público.

A frequência dessas mutações constitucionais talvez pudesse, a primeira vista, fazer parecer que o texto constitucional aprovado pela Assembleia Constituinte em 1988 seria dotado de pouca concretude e quase nenhum apelo popular, uma vez que seus sentidos teriam que ser frequentemente alterados por meio das interpretações constitucionais. Afinal, em tese, uma Constituição tão jovem não deveria passar por tantas transformações - seja por meio das numerosas emendas constitucionais ou pelas mutações aqui referidas.

Contudo, a mutação constitucional, a nosso ver, deve ser entendida como sinal de saúde e vitalidade da Constituição, pois permite a sua adaptação aos anseios populares e às realidades sociais mutáveis. Mesmo assim, os críticos poderiam questionar se a sociedade realmente se modifica na mesma proporção com que ocorrem as mutações constitucionais, já que elas são tão amplas em tão pouco tempo de vigência constitucional.

Quanto a isso, temos a responder aos críticos que, além de a sociedade contemporânea ser altamente mutável, a sociedade brasileira especificamente ainda está em processo de adaptação e consolidação de um regime democrático, de forma que vem construindo os significados constitucionais com a sua vivência política, verificando as necessidades sociais no dia-a-dia e averiguando situações que, antes do advento da democracia, jamais poderiam ser previstas ou pensadas na realidade nacional.

Portanto, retomando a tese de Bruce Ackerman sobre as mudanças constitucionais, entendemos que, em muitos aspectos, podemos hoje considerar que o Brasil viva, em geral, um momento excepcional de mobilização popular a autorizar modificações substanciais no conteúdo e nos conceitos constitucionalmente previstos. 
E por mais que a mutação se dê, por vezes, relativamente a direitos fundamentais que sequer parecem tão fundamentais assim, ela é um reflexo, no nosso entender, do exercício da cidadania em um momento que podemos considerar como excepcional e que autoriza essa espécie de interpretação modificativa de sentidos da Constituição.

Afinal, o significado da Constituição democrática vem sendo desenvolvido e construído aos poucos pela própria sociedade brasileira, que vem se adaptando à democracia aos poucos, verificando as necessidades que esse regime cria e buscando adequar seu pré-compromisso constitucional à realidade presente, mantidos os valores fundamentais e as cláusulas pétreas que definem e conformam o nosso caráter.

Não obstante entendamos que, em muitos aspectos, podemos considerar que a sociedade se encontra em movimento de mobilização excepcional decorrente do próprio status de definição social e de adaptação democráticos, essa situação nem sempre pode ser verificada de tal forma a justificar posturas judiciais que deixam de ser meramente ativas para passarem a ser ativistas, como já demonstramos acima.

E por fim, levando em conta as análises dos casos concretos que nos propusemos a examinar, bem como as conclusões parciais a que nos foi possível chegar, podemos concluir que, a nosso ver, a postura do Supremo Tribunal Federal em relação à efetividade dos direitos fundamentais é uma postura ativa - mas não ativista -, tendente a realizar mutações constitucionais adequadas e proporcionais e sempre com o objetivo de promover a máxima eficácia dos preceitos fundamentais, aplicando-os de forma direta e independente de regulamentação, tendo em vista a própria previsão constitucional que assim determina a atuação do STF.

\subsection{Uma defesa dessa postura}

Por todos os casos que analisamos, concluímos que a tendência do Supremo Tribunal Federal, quando confrontado com casos concretos em que deve decidir sobre a aplicabilidade e eficácia de direitos fundamentais, é a de adotar uma postura ativa, podendo implicar ou não mutação constitucional. 
Percebemos, ainda, a assunção da sua função contramajoritária, mantendo posicionamentos que, em muitos casos, sabe serem contrários à vontade popular, sempre sob a justificativa de preservar os princípios fundamentais e assegurar a validade e eficácia da Constituição.

Essa postura, contudo, não é isenta de críticas. Muito pelo contrário. Críticas diversas são feitas ao Supremo Tribunal Federal, ora acusando-o de excessivo ativismo - com o qual já demonstramos não concordar, por questões de especificidades técnicas e conceituais já apontadas - ora de extrapolar as suas funções judicantes imiscuindo-se em ramos de atuação destinados a outros poderes e, por vezes, por representar um posicionamento aparentemente antidemocrático em afronta à primazia do Legislativo.

Todavia, essas críticas, como fomos capazes de pontuar ao longo do presente trabalho, não são procedentes, afigurando-se a postura geralmente adotada pelo Supremo Tribunal Federal como a mais adequada aos seus intentos de preservação e promoção da máxima eficácia dos direitos fundamentais.

Inicialmente, há que se reforçar o caráter e importância dos direitos fundamentais e a relevância de sua positivação na Constituição, após um processo político de mobilização popular e superação de um modelo político autoritário e ditatorial para a instauração de uma efetiva democracia.

Reconhecida a importância desses direitos, que foram conquistados ao longo de vários anos, por meio de lutas sociais diversas, com repercussões extremas na conformação social mundial, especialmente nas sociedades ocidentais, torna-se evidente a primazia de qualquer postulado tendente a sua preservação e eficácia.

Porém, por serem disposições genéricas, com pouca concretude semântica e, em geral, amplos espaços de conformação interpretativa, necessário se fez o desenvolvimento de uma técnica de interpretação que pudesse fazer valer esses direitos, aplicando-os de forma eficiente. E dentre as diversas técnicas desenvolvidas para realizar esse trabalho interpretativo, a que nos pareceu mais fundamentada e racional foi a da ponderação. 
Essa metodologia -- que busca interpretar princípios em conflito no caso concreto de forma a preservar ao máximo a eficácia de ambos, evitando a anulação de um para a preservação do outro -- é o instrumento principal e essencial da postura ativa do Supremo Tribunal Federal em relação à efetividade dos direitos fundamentais.

Entretanto, também é essa técnica responsável por uma das principais críticas a essa postura ativa - a de que ela não passa de justificativa fabricada para fazer prevalecer o entendimento pessoal e subjetivo do juiz.

Também como vimos, essa crítica é de fato procedente, mas apenas nas hipóteses em que não haja o respeito aos critérios de orientação da ponderação, dentre os quais destacamos o juízo da proporcionalidade e o respeito ao discurso jurídico devidamente fundamentado.

No caso do julgamento da Ficha Limpa, em que entendemos ter havido uso equivocado da ponderação, o fizemos por apontar a ausência de justificação externa idônea da fundamentação construída, tendo em vista a distorção realizada nas premissas da interpretação, mais especificamente quanto à restrição de extensão e significado aos direitos políticos e quanto à consideração da presunção de inocência como regra e não como princípio e, como tal, aplicável apenas no âmbito penal.

Como se vê, os resultados inadequados da ponderação apenas surgem quando seus juízos não são corretamente fundamentados, deixando de levar em conta os aspectos que acima pontuamos acerca dessa técnica interpretativa.

Portanto, desde que realizado corretamente e observando todos os critérios de racionalidade inerentes à execução da técnica da ponderação, ela é capaz de produzir resultados absolutamente racionais, desnaturando a crítica de que esse juízo seria apenas mera desculpa para a imposição de valores subjetivos dos julgadores.

Também se afiguram improcedentes as críticas no sentido de que o posicionamento ativo do Judiciário frente às questões envolvendo direitos fundamentais representaria indevida intromissão na esfera de atuação dos demais poderes. 
Igualmente aqui entendemos que a improcedência da crítica começa pela constatação de um equívoco de premissa, consistente na concepção do princípio de separação de poderes.

Como vimos, esse princípio republicano não pode ser interpretado de forma estanque, deixando de considerar as suas matizações e a doutrina dos freios e contrapesos que admite e até incentiva que os limites de atuação de cada um dos Poderes sejam fluidos, muitas vezes se interpenetrando.

Da mesma maneira, a conformação social pode até mesmo modificar essa concepção tradicional de forma decisiva passando a adotar, ao invés da tradicional nomenclatura da divisão tripartite de poderes entre Executivo, Legislativo e Judiciário, as funções de instância de decisão conformadora da política pública, de execução da política pública e de controle dessa política ${ }^{223}$.

Além disso, a postura ativa do Supremo Tribunal Federal não se dá, em geral, fora dos limites de atuação definidos pelo próprio legislador constituinte quando da redação do texto constitucional.

Isso porque a Constituição prevê textualmente, de forma bastante clara, que ao Supremo Tribunal Federal compete a guarda da Constituição e que os direitos fundamentais nela previstos devem ser aplicados diretamente, independentemente de qualquer regulamentação legislativa. Ou seja, a própria Carta Magna não só elenca os princípios constitucionais vigentes, como também os declara auto-aplicáveis, de forma que ao agir de maneira a assegurar sua máxima efetividade, o Supremo Tribunal Federal nada mais está a fazer que exercer as atribuições que lhe foram conferidas pela própria Constituição.

E tendo sido a Constituição elaborada pela Assembleia Constituinte e modificada por diversas emendas constitucionais posteriores - todas de autoria do Poder

\footnotetext{
${ }^{223}$ Conforme transcrição da p. 61 (NR 122).
} 
Legislativo Derivado -, é lícito afirmar que essa atribuição ativa do Supremo the foi outorgada pelo próprio Poder Legislativo.

Sendo assim, as críticas feitas ao Judiciário e, especialmente, ao STF, por adotar postura ativa na interpretação dos direitos fundamentais e na conferência de plena efetividade a eles mediante sua aplicação imediata, na verdade deveriam ser dirigidas ao Legislador Constituinte, que assim conformou as balizas de atuação do Judiciário no texto constitucional, estando o Supremo apenas a agir dentro desses limites previamente definidos.

E não só ao legislador constituinte deveriam ser dirigidas essas críticas, mas também ao poder constituinte derivado, que falha não apenas no controle preventivo de constitucionalidade de diversas leis que aprova, mas também e, principalmente, na sua omissão relevante quanto à ausência de positivação e de regulamentação de direitos, bem como de definição e concretização de políticas públicas, fazendo com que o Judiciário seja cada vez mais acionado para, sempre dentro de suas atribuições constitucionais, suprir as omissões e reparar as inconstitucionalidades.

Dessa forma e pelas mesmas razões, também não procedem as críticas de que a postura efetivamente adotada pelo Supremo, que classificamos de ativa, seja antidemocrática porque tomada no âmbito de uma instituição que não é formada por representantes eleitos pelo povo.

Apesar de realmente não ser composta por representantes eleitos, a cúpula do Judiciário age, na grande maioria das vezes, em favor da população e em conformidade com os mandamentos constitucionais que foram aprovados pelo Legislador que possui, esse sim, legitimidade democrática.

Portanto, também quanto a esse ponto a crítica deveria ser voltada ao Poder Legislativo e à crise de representação hoje enfrentada no país, com o descrédito desse poder, o loteamento do Congresso com representantes que visam ao atendimento apenas de seus próprios interesses e o alto índice de corrupção que todos sabem assolar o ambiente político nacional. 
E nem adianta argumentar que a atuação ativa do Judiciário apenas faria aumentar esse abismo existente entre a população e seus representantes políticos e a crise de representação que hoje se afigura nesse âmbito, porque se tratam de esferas diversas de poder com atuações e formações distintas.

Desse modo, não se pode culpar o Judiciário por eventual descrédito do Legislativo e nem pretender que esse primeiro Poder não exerça plenamente as suas atribuições apenas porque isso poderia implicar maior descrédito do Legislativo, mesmo porque não se pode prejudicar a atuação idônea de um Poder sob o pretexto de que isso auxiliaria na recuperação do prestígio do outro.

Assim, resta evidente que as críticas atribuídas à postura ativa do Judiciário estão equivocadas em diversos sentidos, ora porque se fundamentam em premissas erradas - confundindo conceitos técnicos e atribuindo supostos excessos ao Judiciário que, na verdade, são meramente obrigações de atuação constitucionalmente previstas -, ora porque são dirigidas ao responsável errado, buscando atribuir ao Judiciário as responsabilidades pelas deficiências dos demais Poderes.

Em suma, outra não poderia ser a postura do Supremo Tribunal Federal quanto aos direitos fundamentais e a sua efetividade, restando clara a idoneidade, legitimidade, correção e racionalidade de sua postura ativa na preservação e promoção da máxima eficácia desses direitos. 


\section{REFLEXÕES CONCLUSIVAS}

A postura do Supremo Tribunal Federal na efetividade dos direitos fundamentais é, portanto, ativa.

Mas não se confunda Judiciário ativo com Judiciário ativista, pois o primeiro age dentro das balizas de atuação constitucionalmente definidas, enquanto o segundo as extrapola, falhando na argumentação racional de suas decisões.

A proatividade do Judiciário é consequência lógica e inafastável da consideração dos direitos fundamentais como componentes de uma ordem objetiva de valores, que atribui a esses direitos eficácia irradiante e que, pelo reconhecimento de sua dimensão objetiva, atribui ao Estado deveres de proteção desses direitos.

E correspondentes a esses deveres de proteção encontram-se direitos subjetivos dos cidadãos, que podem e devem exigir o cumprimento e atendimento dos direitos fundamentais que lhe são constitucionalmente garantidos.

Se essa garantia não é obtida por meio da atuação do Poder Legislativo ou do Poder Executivo, os cidadãos não só podem como devem acionar o Judiciário para verem cumpridos e garantidos os seus direitos, bem como para que seja preservada a força normativa da Constituição.

Acionado o Judiciário, não pode ele adotar qualquer postura diversa da que vem adotando, devendo sempre buscar interpretar e aplicar os princípios fundamentais, mesmo quando eles tenham que se sobrepor a regras já superadas ou quando tenham que servir de única fundamentação a um provimento judicial definitivo.

Contudo, essa postura ativa, a aplicação direta de princípios e o uso da técnica da ponderação devem sempre ser racionalmente fundamentados, por meio da utilização de critérios e argumentos da teoria do discurso, para que revistam-se de racionalidade indiscutível, rechaçando desde logo qualquer das críticas frequentemente feitas ao Judiciário nacional. 
E assim o Supremo Tribunal Federal cumpre a sua missão constitucional de guarda da Constituição e preserva os direitos fundamentais que são os postulados mais importantes que os cidadãos possuem a seu favor em um Estado Democrático de Direito. 


\section{BIBLIOGRAFIA}

ACKERMAN, Bruce. Nós, o Povo Soberano - Fundamentos do Direito Constitucional. Belo Horizonte: Del Rey, 2006.

- Transformação do Direito Constitucional - Nós, o Povo Soberano. Belo Horizonte: Del Rey, 2008.

ALEXY, Robert. Conceito e validade do Direito. São Paulo: Martins Fontes, 2009.

. Constitucionalismo discursivo. Porto Alegre: Livraria do Advogado, 2008.

. Direito, Razão, Discurso. Estudos para a filosofia do direito. Porto Alegre: Livraria do Advogado, 2010

La Teoría del Discurso y Los Derechos Fundamentales. In.: MENÉNDEZ, Agustín José e ERIKSEN, Erik Oddvar (org.) La argumentación y los derechos fundamentales. Madrid: Centro de Estudios políticos y Constitucionales, 2010.

Teoria da Argumentação Jurídica - A teoria do discurso racional como teoria da justificação jurídica. São Paulo: Landy, 2005.

Teoría de los Derechos Fundamentales. Madrid: Centro de Estudios Politicos y Constitucionales, 2007.

ÁVILA, Humberto. Neoconstitucionalismo: entre a "ciência do direito" e o "direito da ciência”. in: Vinte anos da Constituição Federal de 1988. Rio de Janeiro: Lumen Juris, 2009.

BARCELlOS, Ana Paula de. Alguns Parâmetros Normativos para a Ponderação Constitucional. in: BARROSO, Luís Roberto (org.) A Nova Interpretação Constitucional - Ponderação, Direitos Fundamentais e Relações Privadas. Rio de Janeiro: Renovar, 2006. 
BARROS, Sérgio Resende. Contribuição Dialética para o Constitucionalismo. Campinas: Millennium, 2008.

BARROSO, Luís Roberto. Interpretação e Aplicação da Constituição. São Paulo: Saraiva, 2007.

BELLAMY, Richard. Policital Constitutionalism: a Republican Defence of the Constitutionality of Democracy. New York: Cambridge University Press, 2007 (versão para kindle).

BELlO FILHO, Ney de Barros. Sistema Constitucional Aberto. Belo Horizonte: Del Rey, 2003.

BICKEL, Alexander M. The Least Dangerous Branch - the Supreme Court at the Bar of Politics. New Haven: Yale University Press, 1962.

BINENBOJM, Gustavo. A Nova Jurisdição Constitucional Brasileira - Legitimidade democrática e instrumentos de realização. Rio de Janeiro: Renovar, 2010.

BOBBIO, Norberto, A Era dos Direitos. Rio de Janeiro: Campus, 1992.

BRANCO, Paulo Gustavo Gonet. Juízo de Ponderação na Jurisdição Constitucional. São Paulo: Saraiva, 2009.

CANARIS, Claus-Wilhelm. Direitos Fundamentais e Direito Privado. Coimbra: Almedina, 2006

CANOTILHO, J.J. Gomes Direito Constitucional Coimbra: Almedina, 1991.

CARBOnEll, Miguel. Prólogo: Nuevos Tiempos Para El Constitucionalismo. in: CARBONELL, Miguel (org.) Neoconstitucionalismo(s). Madrid: Editorial Trotta, 2009.

CARRESE, Paul O. The Cloaking of Power - Montesquieu, Blackstone and the Rise of Judicial Activism. Chicago: The University of Chicago Press, 2003 (versão para kindle). 
COMELLA, Víctor Ferreres. Constitutional Courts \& Democratic Values - a european perspective. New Haven: Yale University Press, 2009.

DAHL, Robert. A. How Democratic is the American Constitution? New Haven: Yale University Press, 2000 (versão para kindle).

DANTAS, Miguel Calmon. Constitucionalismo Dirigente e Pós-Modernidade. São Paulo: Saraiva, 2009.

DIMOULIS, Dimitri e MARTINS, Leonardo. Teoria Geral dos Direitos Fundamentais. São Paulo: Editora Revista dos Tribunais, 2007

DOW, David R. America's Prophets - how judicial activism makes America great. Westport, Praeger, 2009.

DWORKIN, Ronald. O Império do Direito. São Paulo: Martins Fontes, 2007. Levando os direitos a sério. São Paulo: Martins Fontes, 2007.

ELSTER, Jon. Ulisses Liberto - estudos sobre racionalidade, pré-compromisso e restrições. São Paulo: Editora UNESP, 2009.

ELY, John Hart. Democracia e Desconfiança - uma teoria do controle judicial de constitucionalidade. São Paulo: Martins Fontes, 2010.

FERRAZ, Anna Candida da. Processos Informais de Mudança da Constituição. São Paulo: Max Limonad, 1986.

FERREIRA FILHO, Manoel Gonçalves. Aspectos do Direito Constitucional Contemporâneo. São Paulo: Saraiva, 2009. Estado de Direito e Constituição, São Paulo: Saraiva, 2009. 
. Princípios Fundamentais do Direito Constitucional. São Paulo: Saraiva, 2010.

. O Papel Político do Judiciário e suas Implicações. in: Systemas, Revista de

Ciências Jurídicas e Econômicas. Ano 1, n. 2. Disponível em: http://www.revistasystemas.com.br/index.php/systemas/article/view/21/16. Acesso em 18.11.2012.

GINSBURG, Tom. Judicial Review in New Democracies - Constitutional Courts in Asian Cases. Cambridge: Cambridge University Press, 2003 (versão para kindle).

GOMÉZ, Maria Isabel Garrido. Derechos Fundamentales y Estado Social y Democrático de Derecho. Madrid: Editorial Dilex, sem ano.

HABERMAS, Jürgen. Direito e Democracia - entre facticidade e validade. Volume 1. Rio de Janeiro: Tempo Brasileiro, 2010.

HESSE, Konrad. A Força Normativa da Constituição. Porto Alegre: Sergio Antonio Fabris Editor, 1991.

HIRSCHL, Ran. Towards Juristocracy - the origins and consequences of the new constitutionalism. Cambridge: Harvard University Press, 2007.

KAUFMANN, Rodrigo de Oliveira. Dimensões e Perspectivas da Eficácia Horizontal dos Direitos Fundamentais - Possibilidades e Limites da Aplicação no Direito Constitucional Brasileiro. Dissertação apresentada como requisito para adquirir o título de mestre, na UnB, em 2003. Orientador: José Carlos Moreira Alves.

KELSEN, Hans. A Democracia. São Paulo: Martins Fontes, 2000. . Jurisdição Constitucional. São Paulo: Martins Fontes, 2007.

LANDFRIED, Christine. Germany. in: TATE, C. Neal e VALLINDER, Torbjörn (org.) The Global Expansion of Judicial Power. New York: New York University Press, 1995. 
LEWIS, Frederick P. The Context of Judicial Activism - the endurance of the Warren Court legacy in a Conservative Age. Lanham: Rowman \& Littlefield Publisher Inc., 1999.

LOEWENSTEIN, Karl. Teoria de la Constitución. Barcelona: Editora Ariel 1986.

MARTÍNEZ-PUJALTE, Antonio-Luis e DOMINGO, Tomás de. Los derechos fundamentales en el sistema constitucional - Teoría general e implicaciones prácticas. Granada: Editorial Comares, 2011.

MENDES, Gilmar Ferreira; COELHO, Inocêncio Mártires e BRANCO, Paulo Gustavo Gonet. Curso de Direito Constitucional. São Paulo: Saraiva, 2007.

MORAES, Alexandre de. Direito Constitucional. São Paulo: Atlas, 2009.

MORESO, José Juan. Conflictos entre Principios Constitucionales. in: CARBONELL, Miguel (org.) Neoconstitucionalismo(s). Madrid: Editorial Trotta, 2009.

NOWAK, John E. e ROTUNDA, Ronald D. Constitutional Law. Saint Paulo: Thomson West, 2004.

OLIVEIRA, Fábio Corrêa Souza de. Morte e Vida da Constituição Dirigente. Rio de Janeiro: Lumen Juris, 2010. pp. 80-83.

PEREIRA, Anthony W. Of Judges and Generals: Security Courts under Authoritarian Regimes in Argentina, Brazil, and Chile. In: GINSBURG, Tom e MOUSTAFA, Tamir (org.) Rule by Law - the policits of Courts in authoritarian regimes. New York, Cambridge University Press, 2008 (versão para kindle).

POWERS, Stephen P. E ROTHMAN, Stanley. The Least Dangerous Branch? Consequences of Judicial Activism. Westport: Praeger, 2002 (versão para kindle).

RAMOS, Elival da Silva. Ativismo Judicial. Parâmetros Dogmáticos. São Paulo: Saraiva, 2010. 
REHNQUIST, William H. The Supreme Court. New York: Vintage Books, sem indicação de ano (versão para Kindle).

ROBERTSON, David. The Judge as Policital Theorist. Princeton: Princeton University Press, 2010 (versão para kindle).

ROOSEVELT III, Kermit. The Myth of Judicial Activism - making sense of Supreme Court Decisions. New Haven: Yale University Press, 2006 (versão para kindle).

SARLET, Ingo Wolfgang. A Eficácia dos Direitos Fundamentais. Porto Alegre: Livraria do Advogado, 2007.

SARMENTO, Daniel, Direitos Fundamentais e Relações Privadas, Rio de Janeiro: Lumen Juris, 2006.

SCHMITT, Carl. O Guardião da Constituição. Belo Horizonte: Del Rey, 2007.

SHAPIRO, Martin e SWEET, Alec Stone. On Law, politics, \& Judicialization. New York: Oxford University Press Inc., 2002.

SILVA, Virgílio Afonso da. Direitos Fundamentais - conteúdo essencial, restrições e eficácia. São Paulo: Malheiros, 2009.

STRECK, Lenio Luiz. Hermenêutica Jurídica E(m) Crise - Uma exploração hermenêutica da construção do Direito. Porto Alegre: Livraria do Advogado, 2009.

SUTHERLAND, Mark I. Redefining the Rules. In: SUTHERLAND, Mark I. (org.) Judicial Tyranny - the new kings of america? Saint Louis: Amerisearch, 2007 (versão para kindle).

TUSHNET, Mark. Taking the Constitution Away From the Courts. Princeton: Princeton University Press, 1999. 
. Weak Courts, Strong Rights - judicial review and social welfare rigts in comparative constitutional law. Princeton: Princeton University Press, 2008 (versão para Kindle).

. Why the Constitution Matters. New Haven: Yale University Press, 2010 (versão para kindle).

VALE, André Rufino do Eficácia dos Direitos Fundamentais nas Relações Privadas. Porto Alegre: Sérgio Antonio Fabris Editor, 2004.

WRÓBLEWSKI, Jerzy. Constitución y teoria general de la interpretación jurídica. Madri: Cuadernos Civitas, 1985. 